\title{
OBSERVATIONS ON THE TAXONOMY AND DISTRIBUTION OF CHAETOGNATHS OF THE NORTH PACIFIC
}

\author{
$\operatorname{AUTHOR}(\mathrm{S}):$ \\ Tokioka, Takasi
}

\section{CITATION:}

Tokioka, Takasi. OBSERVATIONS ON THE TAXONOMY AND DISTRIBUTION OF CHAETOGNATHS OF THE NORTH PACIFIC. PUBLICATIONS OF THE SETO MARINE BIOLOGICAL LABORATORY 1959, 7(3): 349-456

ISSUE DATE:

1959-12-20

URL:

http://hdl.handle.net/2433/174631

RIGHT: 


\title{
OBSERVATIONS ON THE TAXONOMY AND DISTRIBUTION OF CHAETOGNATHS OF THE NORTH PACIFIC ${ }^{1)}$
}

\author{
TAKASI TOKIOKA
}

Seto Marine Biological Laboratory, Sirahama

With 35 Text-figures and 74 Tables

\section{CONTENTS}

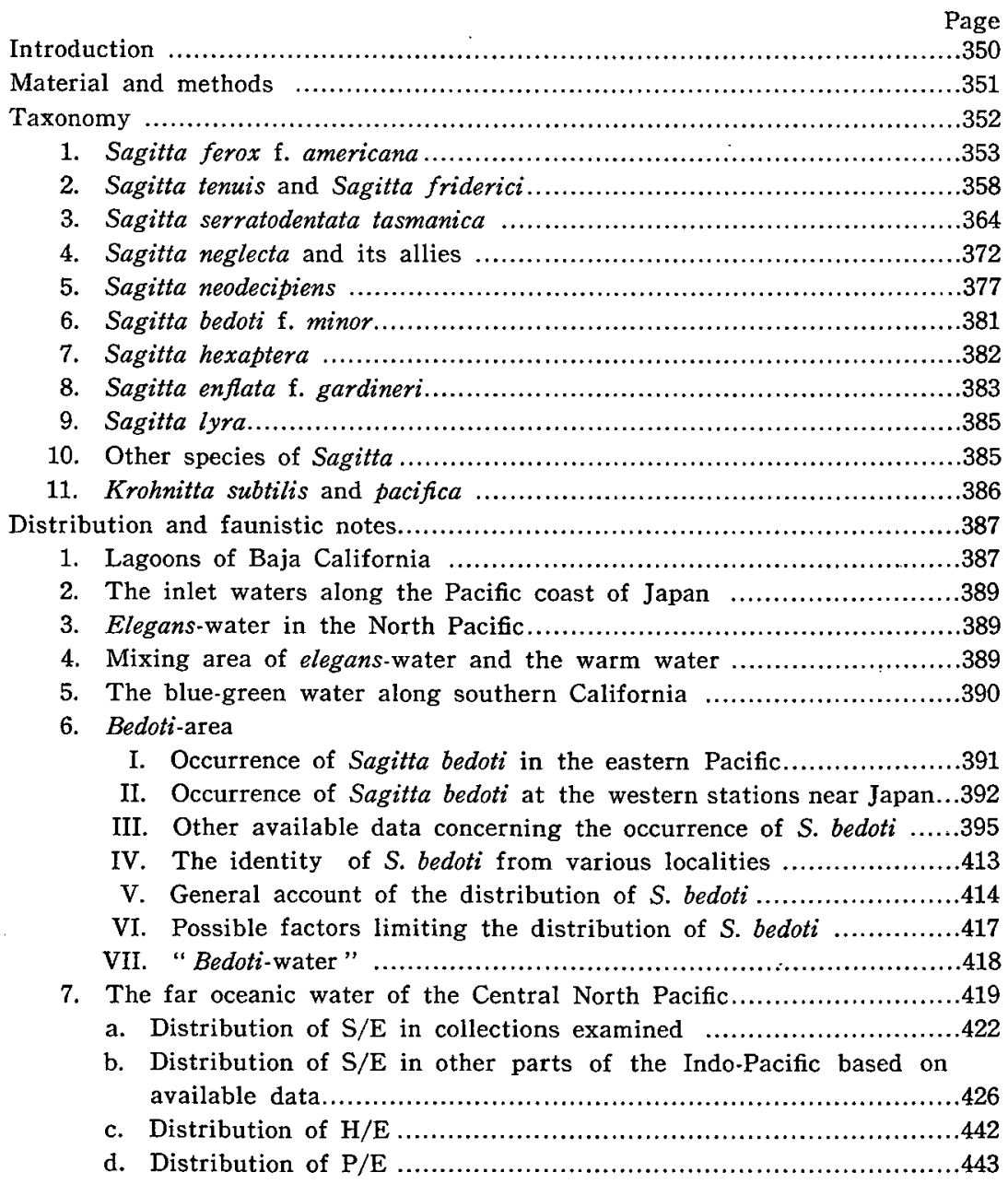

1) Contributions from the Seto Marine Biological Laboratory, No. 339.

Publ. Seto Mar. Biol. Lab., VII (3), 1959. (Article 25) 
e. Distribution of other prominent species .443

8. Differentiation found in the chaetognath fauna of the North Pacific and the relation between communities and water masses ................444

Summary and conclusions ....................................................449

References .......................................................................450

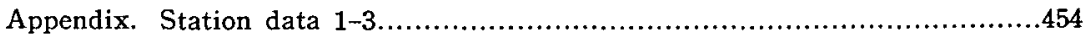

\section{Introduction}

Although I had a chance to look through a part of vast collection of plankton samples kept at the Scripps Institution of Oceanography and to examine a considerable number of specimens of chaetognaths during my stay there in 1956-57, I have refrained from publishing papers on this animal group, because I knew at that time that Mr. R. BIERI had already accumulated a great many data on chaetognaths during his long stay at Scripps and had begun to prepare manuscripts for publication. Now, two of his papers (1957 and 1959) have been published on the Pacific chaetognaths. The second paper is especially very important in giving a comprehensive outline of the distribution of different species in the North Pacific. Previous works on Pacific chaetognaths are all covered in the second paper. Five subsequent papers on the Pacific chaetognaths have appeared, two by FAGETTI (1958 a, b) on material from Chilean waters and three by Sund $(1959 \mathrm{a}, \mathrm{b}, \mathrm{c})$ on material from the Gulf of Alaska and eastern tropical waters.

My data shown in the tables appended at the end of this article appear to contribute only supplemental information to the distribution-charts of the respective species as given by BIERI (1959), but the results of closer morphological examinations on the material comprise some new findings. A new species and a new form was found in the material from the eastern tropical Pacific. The tenuis-friderici problem is discussed again on Pacific specimens, the range of morphological variations is reviewed in some species and a few morphological notes on some additional species are presented. In addition, the relative abundance of the four important species (Sagitta enflata, S. serratodentata pacifica, S. hexaptera and Pterosagitta draco) is defined by computing ratios between $S$. enflata and each of serratodentata pacifica, hexaptera and $P$. draco. This procedure seems to indicate a relation between the chaetognath fauna and some water-masses more clearly than previously shown. The distribution of Sagitta bedoti in the western Pacific and the Indian Ocean is reviewed in detail on the basis of present material and also on previous records published to date. This leads to the conclusion that a characteristic water mass of comparatively large extent, the bedoti-water, can be defined distinctly in the Indo-Pacific.

Before going further, I want to express my hearty thanks to the staff of the Scripps Institution of Oceanography for granting me the favour of a seat at the laboratory for a year, especially to Prof. M. W. JoHNSON for his kindness in providing facilities and for reading the manuscript; and also to the Rockefeller Foundation for a postdoctoral fellowship. 


\section{Material and Methods}

The material examined consists of the following 326 plankton samples:

1. Transpac Expedition 1953: 130 samples collected from $50 \mathrm{~m}$ to the surface by means of a small net having a $17 \mathrm{~cm}$ diameter mouth; 19 samples collected by a Japanese survey ship off north eastern Honsyô, Japan were presented to the research party of the Expedition. These samples were taken vertically from $50 \mathrm{~m}$ to the surface by using KITAHARA's quantitative net, a small modified HENSEn's net. A sample of the North Pacific Stranger Expedition (1955) was examined and the result is given at the end of the table of the Transpac Expedition.

2. Midpac Expedition 1950: 57 samples taken by various gears and also from various depths.

3. Shellback Expedition 1952: 48 samples, one of every five stations, were examined. The samples were collected with a large net from about $300 \mathrm{~m}$ to the surface.

4. Equapac Expedition 1956: Five of many samples were examined; they were taken with a large net from $200-400 \mathrm{~m}$ to the surface.

5. The blue-green water survey: 54 samples taken with a small net, having a 17 $\mathrm{cm}$ diameter mouth; of these 35 were collected off San Diego, and 19 were collected March 12-13, 1956 in the area extending from San Diego to Long Beach.

6. Lagoon samples: Ten samples from Scammons lagoon, Oct. 9-12, 1955 and two samples from Manuela lagoon, Oct. 12, 1952. All these samples were collected by members of the Foraminifera Laboratory of the Scripps Institution of Oceanography under the direction of Prof. F. B. PhLEger. I am very grateful to Prof. PhLEger and the members of the Laboratory for their kindness in allowing me to examine these samples and to quote some of the hydrographical data in this paper.

7. In addition, the data obtained by examining the samples collected during the Palao-New Guinea cruises 1940 made by the former Japanese fisheries experimental station at Palao are given herewith.

In treating the samples collected with small nets, the whole of each sample was examined with a magnification of $30 \times$. Every individual of each species was identified carefully and counted. In treating the large net samples, however, only one fourth of each sample was examined in this way. The crude data, thus obtained, are arranged in 8 tables appended at the end of this paper. In measuring the body length or the length of the caudal segment, the caudal fin was always included. When the teeth were counted, the anterior portion of the head was dissected off under the binocular, the dental area was mounted and examined under the microscope. The corona ciliata was observed by staining it with rose bengal; the existence of the intestinal diverticula was ascertained by making the specimens transparent with glycerine and examining them under the microscope. The arrangement of fin rays and the number of eggs were determined under the microscope. When it was necessary to measure some small distances, the objects were drawn on a sheet of paper by using a camera lucida and the measurements were made from these sketched 
figures. In computing percentages, ratios and means, fractions less than $1 / 2$ were disregarded and the rest were counted as units.

\section{Taxonomy}

In all, the following 30 forms were identified in the whole series of samples:

1. Sagitta hexaptera D'ORBIGNY

2. Sagitta lyra KROHN

3. Sagitta enflata GrASSI

4. Sagitta enflata f. gardineri DONCASTER

5. Sagitta elegans VERRILL

6. Sagitta bipunctata QUOY et GAIMARD

7. Sagitta ferox Doncaster

8. Sagitta ferox f. americana nov.

9. Sagitta robusta DONCASTER

10. Sagitta bedoti BÉRANECK

11. Sagitta pulchra DONCASTER

12. Sagitta tenuis Conant

13. Sagitta friderici RITTER-ZÁHONY

14. Sagitta serratodentata pacifica TokıOKA

15. Sagitta serratodentata pseudoserratodentata TokiokA

16. Sagitta serratodentata tasmanica THOMSON

17. Sagitta neglecta AIDA

18. Sagitta oceania GRAY

19. Sagitta regularis AIDA

20. Sagitta bedfordii DonCASTER

21. Sagitta crassa f. naikaiensis ToKıоKA

22. Sagitta minima GrassI

23. Sagitta decipiens FOWLER

24. Sagitta neodecipiens $\mathrm{n}$. sp.

25. Sagitta planctonis SteinHaus

26. Sagitta macrocephala FOWLER

27. Pterosagitta draco (KROHN)

28. Eukrohnia hamata (MöBIUS)

29. Krohnitta subtilis (GRASSI)

30. Krohnitta pacifica (AIDA)

Most of these species have been described repeatedly and a key to the tropical eastern Pacific Ocean species has been published by Sund (1959b). Hence, only descriptions of two new forms and some notes on problematic forms or on the range of variations will be given together with a few morphological notes. Three subspecies of Sagitta sessatodentata KROHN are printed in tables as species in order to save space. 


\section{Sagitta ferox f. americana nov.}

(Figs. 1-3, Tables 1-4)

A medium-sized species attaining $8.3 \mathrm{~mm}$ in body length of which the tail segment constitutes most frequently 27-29\%. General appearance of the body and the relative size of the head resemble closely those of the typical $S$. ferox, from which it is very difficult to separate even under considerably high magnification. The head is medium in size, not so large as in S. robusta; neck distinct, no constriction at the trunk-tail septum. The collarette is fairly conspicuous at the neck region and reaches to the anterior end of the ventral ganglion, diminishing in thickness posteriorly. The anterior fin begins at the posterior end of the ventral ganglion and without any rayless zone. The posterior fin is a little longer than the anterior and more than half of the fin lies on the tail segment, being widest at the level slightly posterior to the trunk-tail septum; rayless zone is practically absent, except for a very narrow rayless area in front of the aperture of the female genital organ in some individuals. The distance between the anterior and posterior fins is approximately one fourth of the posterior fin. Eye-pigment is rather large, slightly elongate and curved. The corona ciliata (Fig. 1) begins at the posterior margin of the brain in front of eyes, it is about one and a half times as long as the head, and both sides are slightly sinuous; this is slightly shorter than in $S$. robusta. The intestinal diverticula are present

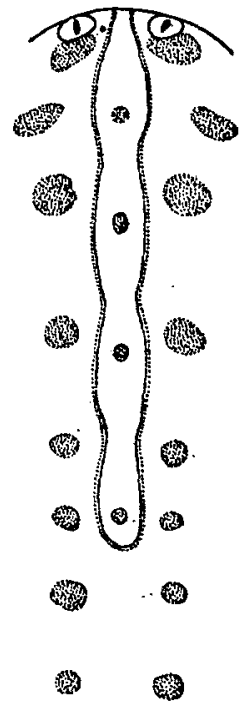

1

Fig. 1. 1-Sagitta ferox f. americana n. f. Corona ciliata (SB 20).

and very distinct. Hooks are most frequently $7-8$ in adults, though they fluctuate from 6 to 9 . The anterior teeth are slender and only slightly fewer than the posterior teeth which are much thicker and usually 10-12 in number (fluctuate from 9 to 14) in mature individuals. Frequently the anterior teeth may equal, or in some cases, exceed the posterior teeth in number. This was observed only in mature specimens larger than $6.7 \mathrm{~mm}$ (in 12 of 22 specimens examined longer than $6.7 \mathrm{~mm}$ ). The difference in number between the anterior and posterior teeth is larger in smaller immature individuals than in mature ones. Rows of the anterior teeth usually meet 


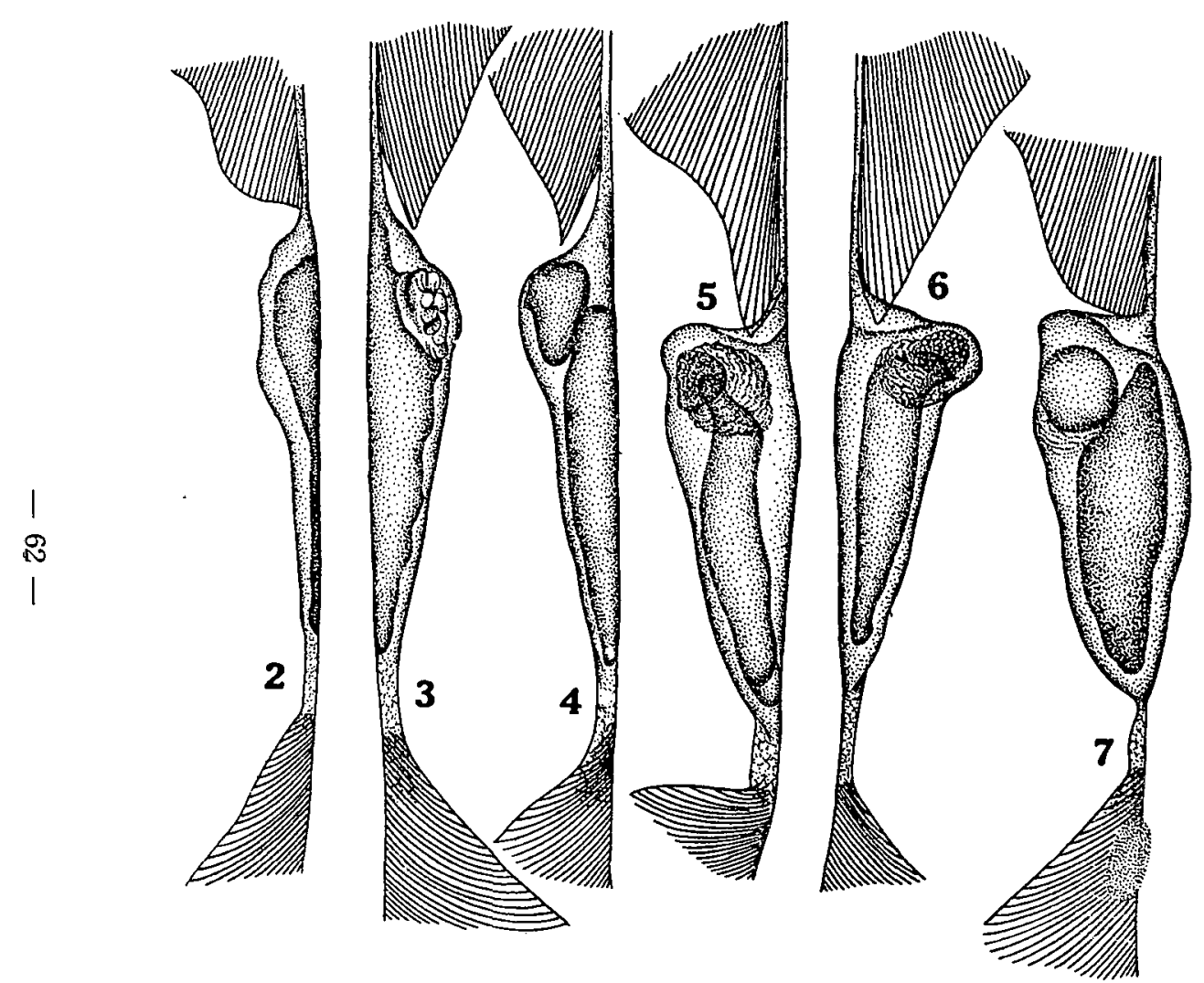

Fig. 2. Sagitta ferox f. americana n.f. Seminal vesicles arranged in the order of maturity. $\times 125 ; 2-4-(\mathrm{SB} 20)$ ventral ; 5-6-(SB 60), ventral ; 7-(SB 20), ventral ; 8-6.8 mm long individual (SB 210), 9-ruptured (SB 60), ventral ; 10-ruptured (SB 60), dorsal. 
in an acute angle, but in obtuse angles on some widely expanded heads. Both hooks and teeth are brownish. Fully mature ovaries reach near the neck. The seminal vesicle (Fig. 2) is situated very near the rear end of the posterior fin, being slightly apart from the base of the tail fin. The distance between the vesicle and the tail fin is, however, very small and also very variable. In some cases, it is practically indiscernible, while in others it may reach up to $24 \%$ of the length of the vesicle; thus the ratio, the distance between the vesicle and the tail fine/the vesicle length, fluctuates from 0 to 0.24 , being 0.14 on an average of 12 measured individuals. In structure the vesicle consists of a glandular anterior portion and a voluminous posterior sperm sac which can be seen clearly when the specimen is examined in the light field under the microscope. But externally, the distinction between the anterior and posterior portions of the vesicle is indistinct. Thus, the situation and the outline of the vesicle resemble more closely those of S. ro. busta rather than those of $S$. ferox, although the fully mature vesicles are more voluminous than in $S$. robusta. Rupture occur at the antero-lateral side. The seminal vesicle of typical ferox usually touches both the posterior and tail fins (the distance between the vesicle and tail fin/the vesicle length may reach 0.12 in some cases) and consists of a very conspicuous anterior glandular portion and a posterior saccular portion. There is also

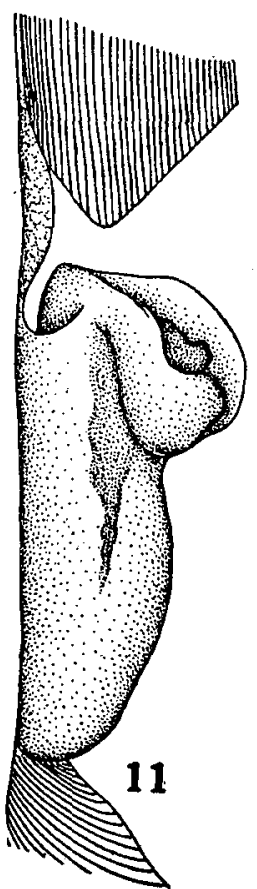

Fig. 3. Sagitta ferox Doncaster. Seminal vesicle of a $6.7 \mathrm{~mm}$ long individual. $\times 125($ EQP H-3)

a swelling of the frothy tissue just in front of the vesicle in perfectly preserved specimens (Fig. 3); this swelling is quite absent in the present form and also in $S$. robusta. The ovary reaches to the anterior end of the posterior fin in a $5.5 \mathrm{~mm}$ long individual, to the ventral ganglion in a $6.2 \mathrm{~mm}$ long individual and near the neck in a $6.4 \mathrm{~mm}$ long individual. Fully swollen seminal vesicles are found on a $6.2 \mathrm{~mm}$ long individual.

Remarks: The armature formulae of S. robusta are closely related to those of the present form, although the hooks are most frequently $6(5-7)$ in mature robusta 
and the difference in number between the anterior and posterior teeth is slightly larger in robusta than in the present form; besides both hooks and teeth of robusta yellowish rather than brownish. The shape and situation of the seminal vesicle of robusta resemble closely those of the present form. In spite of these resemblances, these two forms can be separated from each other distinctly by the size of the head which is exceedingly larger in S. robusta. Sagitta hispida CONANT from the Caribbean Sea, especially some of the specimens described by SuAREz (1955) from Cuban waters, is also closely related to the present form, the number of hooks and teeth

\begin{tabular}{|c|c|c|c|c|c|c|c|}
\hline $\mathrm{Na}$ & & to & bongt & & post. & 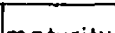 & \\
\hline 1 & 3 & 339 & -9 & $1-5$ & 6 & + & 75 \\
\hline 2 & 4.2 & 31.3 & $9-9$ & $1+*-5$ & $8-8$ & $\mathrm{im}$. & SB 75 \\
\hline 3 & 4.5 & 29.0 & $7-8$ & $4-5$ & $8-8$ & $\mathrm{im}$. & 5868 \\
\hline 4 & 5.5 & 27.1 & $7-7$ & $8-8$ & $10-10$ & med. & SB 55 \\
\hline 5 & 5.9 & 28.6 & $6-7$ & $7-7$ & $11-12$ & med. & SB 55 \\
\hline 6 & 5.9 & 27.8 & $7-7$ & $7-7$ & $10-10$ & med. & SB 75 \\
\hline 7 & 6.0 & 26.9 & $7-7$ & $7-7$ & $9-10$ & med. & SB 64 \\
\hline 8 & 6.2 & 29.5 & $7-7$ & $9-9$ & $10-12$ & $\mathrm{~m}$. & SB 64 \\
\hline 9 & 6.2 & 26.3 & $7-7$ & $7-7$ & $9-10$ & $\mathrm{~m}$. & SB210 \\
\hline 10 & 6.4 & 30.6 & $6-7$ & 8 & 9 & $m$. & SB 30 \\
\hline 11 & 6.6 & 26.7 & $6-6$ & $7-8$ & $9-10$ & $m$ & SB55 \\
\hline 12 & 6.7 & 29.1 & $7-7$ & $10-11$ & $10-10$ & $\mathrm{~m}$. & SB 60 \\
\hline 13 & 6.8 & 28.6 & $8-8$ & $10-10$ & $10 .-10$ & $\mathrm{~m}$. & 58210 \\
\hline 14 & 6.8 & 26.7 & $7-7$ & $12-13$ & $10-10$ & med. & SB 71 \\
\hline 15 & 6.9 & 283 & $7-7$ & $10-10$ & $10-11$ & $\mathrm{~m}$. & SB 60 \\
\hline 16 & 7.0 & 26.9 & $7-7$ & $12-12$ & $12-13$ & $\mathrm{~m}$. & SB60 \\
\hline 17 & 7.2 & 29.1 & $8-8$ & $9-9$ & $11-12$ & $\mathrm{~m}$. & SB64 \\
\hline 18 & 7.3 & 28.6 & $7-8$ & $9-7$ & $9-11$ & $\mathrm{~m}$. & SB 64 \\
\hline 19 & 73 & 26.5 & $6-6$ & $8-8$ & $9-10$ & $\mathrm{~m}$. & SB 71 \\
\hline 20 & 73 & 26.5 & $7-8$ & $9-11$ & $10-10$ & $m$ & SB71 \\
\hline 21 & 7.5 & 26.1 & $7-7$ & $5+*-10$ & $10-10$ & $\mathrm{~m}$. & SB64 \\
\hline 22 & 7.5 & 26.1 & $7-7$ & $3+*-9$ & $5+*-10$ & med. & SB 64 \\
\hline 23 & 7.6 & 29.9 & $7-7$ & 7 & 12 & $\mathrm{~m}$. & SB3O \\
\hline 24 & 7.7 & 27.7 & $7-7$ & $9-9$ & $11-12$ & $\mathrm{~m}$. & SB 60 \\
\hline 25 & 7.7 & 28.6 & $7-7$ & $9-10$ & $12-13$ & $\mathrm{~m}$. & SB 7I \\
\hline 26 & 77 & 27.7 & $8-8$ & $10-14$ & $|1-1|$ & $\mathrm{m}$. & SB75 \\
\hline 27 & 78 & 30.8 & $7-7$ & 9 & 11 & $\mathrm{~m}$. & SB3O \\
\hline 28 & 78 & 27.5 & $7-7$ & $10-11$ & $10-10$ & $\mathrm{~m}$. & SB 68 \\
\hline 29 & 7.9 & 28.1 & $7-7$ & $10-11$ & $10-11$ & $\mathrm{~m}$. & SB68 \\
\hline 30 & 79 & 25.6 & $8-8$ & $9-9$ & $10-10$ & $\mathrm{~m}$. & SBI60 \\
\hline 31 & 8.0 & 27.6 & $7-8$ & $10-1.1$ & $\mid 1-11$ & $\mathrm{~m}$. & SB68 \\
\hline 32 & 8.2 & 286 & $6-7$ & $8-8$ & $10-10$ & $m$. & SBI75 \\
\hline 33 & 8.3 & 27.6 & $7-7$ & $10-10$ & $13-14$ & m. & SBI75 \\
\hline
\end{tabular}

Table 1. Armature formulae of $S$. ferox f. americana n.f.

* Some torn out. SB-.Shellback Exp. 
seems to fall in the range of the variations found in the present form, although the anterior teeth are always slightly fewer than the posterior ones. Mature $S$. hispida are, however, larger than mature specimens of the present form, the ovary dods not reach beyond the frontal end of the anterior fin and the shape of the seminal vesicle resembles that of $S$. bedoti and is separated from the caudal fin by about half the length of the vesicle. Although the general appearance of $S$. ferox resembles that of the present form, the anterior teeth are much fewer by about one half than

2
\begin{tabular}{|c|c|c|c|c|c|c|c|}
\hline No & $\begin{array}{c}\text { body } \\
\text { length }\end{array}$ & $\begin{array}{l}\text { tailseg. } \\
\text { in } \%\end{array}$ & hook & $\begin{array}{c}\text { ant. } \\
\text { te eth }\end{array}$ & $\begin{array}{c}\text { post. } \\
\text { te e th }\end{array}$ & maturity & loc \\
\hline 1 & $6.7 \mathrm{~mm}$ & 29.1 & $8-8$ & $6-7$ & $14-14$ & m. & EQPH3 \\
\hline$? 2$ & 78 & 28.3 & 8 & 6 & 14 & im. & SB 30 \\
\hline 3 & 8.5 & 30.8 & $9-9$ & $6-7$ & $14-14$ & m. & EQPH 17 \\
\hline
\end{tabular}

Sog. robusta

\begin{tabular}{|c|c|c|c|c|c|c|c|}
\hline No & $\begin{array}{c}\text { body } \\
\text { length }\end{array}$ & $\begin{array}{c}\text { tail seg. } \\
\text { in } \%\end{array}$ & hook & $\begin{array}{c}\text { ant } \\
\text { te e in }\end{array}$ & $\begin{array}{c}\text { post. } \\
\text { te e th }\end{array}$ & moturity & loc \\
\hline 1 & $46 \mathrm{~mm}$ & 28.6 & $7-7$ & $5-5$ & $7-8$ & i m. & SB 75 \\
\hline 2 & 63 & 27.8 & $7-7$ & $5-5$ & $8-8$ & i m. & SB 75 \\
\hline 3 & 6.5 & 31.0 & $6-7$ & $6-6$ & $9-11$ & i m. & SB 71 \\
\hline 4 & 85 & 29.0 & $7-7$ & $7-8$ & $12-12$ & i m. & SB64 \\
\hline 5 & 8.5 & 27.5 & $6-6$ & $8-8$ & $12-12$ & i m. & SB95 \\
\hline 6 & 10.4 & 25.0 & $6-6$ & $7-8$ & $12-12$ & $m$ & SB71 \\
\hline 7 & 111 & 29.4 & $6-6$ & $7-8$ & $12-12$. & m. & SB64 \\
\hline 8 & 15.0 & 26.1 & $6-6$ & $6-7$ & $10-10$ & $m$. & SBIO5 \\
\hline
\end{tabular}

4 Sag.robusto collecled by Paul N.Sund (Scot sto.23)

\begin{tabular}{|c|c|c|c|c|c|c|}
\hline No & $\begin{array}{c}\text { body } \\
\text { length }\end{array}$ & $\begin{array}{c}\text { tail seg. } \\
\text { in } \%\end{array}$ & hook & $\begin{array}{c}\text { ont } \\
\text { tee th }\end{array}$ & $\begin{array}{c}\text { post } \\
\text { leeth }\end{array}$ & moturity \\
\hline 1 & $9.5 \mathrm{~mm}$ & 28.4 & $6-6$ & 8 & 13 & $\mathrm{im}$ \\
\hline 2 & 115 & 26.1 & $7-7$ & 10 & 13 & $\mathrm{im}$ \\
\hline 3 & 12.0 & 27.5 & $6-6$ & 10 & 13 & $\mathrm{im}$ \\
\hline 4 & 127 & 299 & $6-6$ & 10 & 13 & $\mathrm{im}$ \\
\hline
\end{tabular}

Tables 2-4. Armature formulae of S. ferox (2) and S. robusta (3-4). EQP...Equapac Exp., SB …Shellback Exp.

the posterior teeth. The structure and situation of the seminal vesicle also differ slightly. Most probably, S. robusta, hispida, ferox and the present form have differentiated from a common ancestor and are very closely related. At present, I can not judge whether the present form is a distinct species or a variety or merely a form of any already known species. Here I can only treat the present form provisionally 
as a local form specialised from S. ferox and restricted to the Shellback area*, since the general appearance of both forms resemble each other so closely. Sagitta helenae RITTER-ZÁHONY conforms to the present form in that the anterior teeth are numerous and usually exceed the posterior ones, but the difference between the two is very distinct, because the former, $S$. helenae, is quite devoid of the intestinal diverticula.

\section{Sagitta tenuis CONANT and Sagitta friderici RitTER-ZÁHONY \\ (Figs. 4-5, Tables 5-8)}

Specimens of S. tenuis from Scammons and Manuela lagoons (Fig. 4) are less than $10.7 \mathrm{~mm}$ in body length and the tail segment occupies about $30 \%$ of the total body length. The body is rather rigid and provided with many tactile setae distributed over the body surface and thus assumes a hispid appearance. Collarette is

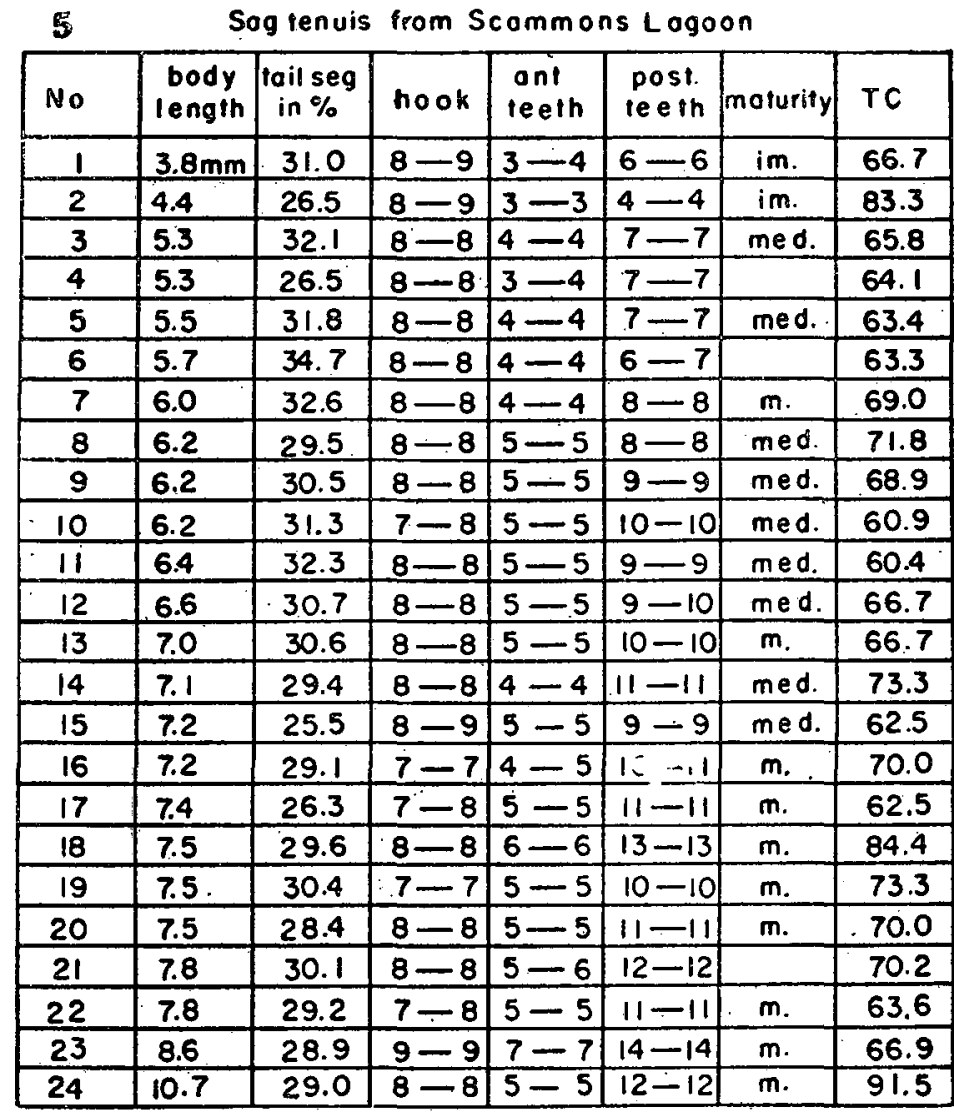

Table 5. Armature formulae of $S$, tenuis from Scammons lagoon.

* The area surveyed by the Shellback Expedition 1952, see Fig. 25. 
distinct near the neck. The anterior fin begins usually at the posterior end of the ventral ganglion, but in larger individuals there is a space of about one half of the ganglion length between the frontal end of the fin and the posterior end of the ganglion. Fin rays are all arranged obliquely towards the posterior; rayless-zone absent. The posterior fin is nearly as long as the anterior and widest at the level posterior to the trunk-tail septum; fin rays are arranged as on the anterior fin, although those near the frontal end are vertical to the base of the fin or even arranged slightly obliquely towards the anterior. Eye-pigments roundish. The corona ciliata is about twice the head length, with two shallow sinuses along each side. The intestinal diverticula absent. The ovary extends slightly beyond the anterior end of the posterior fin at maturity. Ova are usually arranged in two, dorsal and ventral, rows in each ovary and mostly $14-20$ in number in each, the maximum observed was 24 in the $10.7 \mathrm{~mm}$ long individual. The seminal vesicle is elongate, rather low and with the anterior glandular portion slightly swollen. It touches both the posterior and caudal fins. The ratio TC (anterior part of the posterior fin along the trunk/posterior part of the posterior fin along the caudal segment $\times 100$ ) varies from 60.4 to 91.5 , being 69.1 on an average of 24 specimens. The abovementioned features together with the armature formulae (Table 5) evidently refers the specimens to Sagitta tenuis. Rows of anterior teeth meet each other in acute angles.

Other chaetognaths found in the blue-green water along the southern Californian coast and in some samples of the Transpac and Shellback Expeditions, collected at stations near this bluegreen water region, seem to belong to Sagitta friderici. They resemble closely S. tenuis, but differ from that species in the following points :-
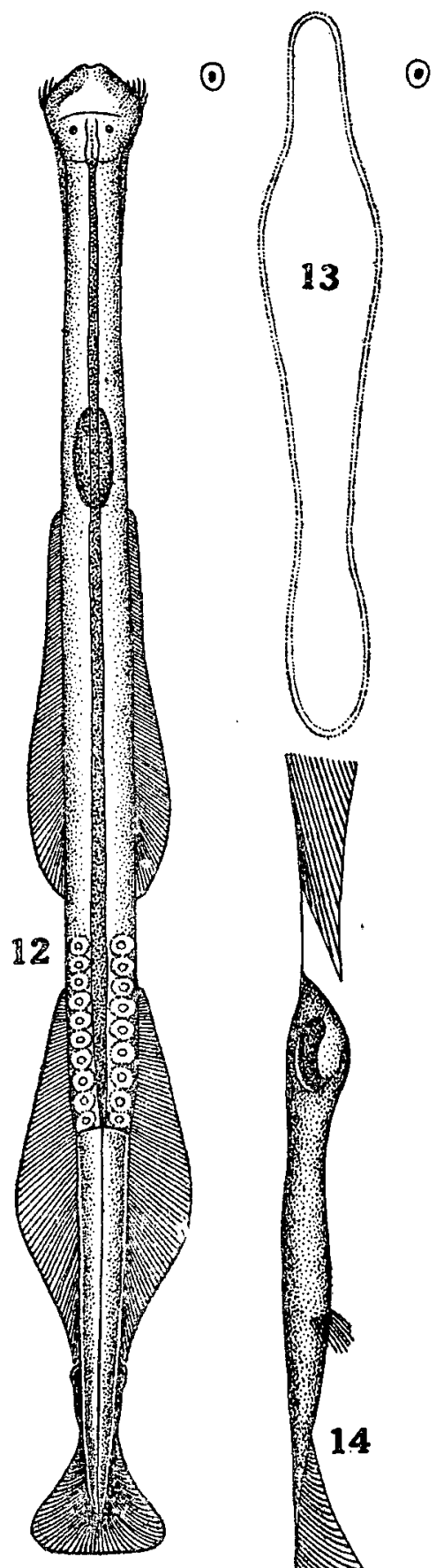

Fig. 4. Sagitta tenuis CoNANT. A $8.6 \mathrm{~mm}$ long individual from Scammons Lagoon. 12-Dorsal side of the animal, $\times 20 ; 13$ Corona ciliata, 14-Seminal vesicle. 
1) mature individuals are larger, attaining $12.8 \mathrm{~mm}$ in length; tail segment is slightly shorter, $26.2 \%$ on an average of 34 measured individuals; 2 ) both the anterior and posterior teeth are fewer than in S. tenuis of the same body length; and 3) TC value is much larger, varying from 76 to 141.7 and 106 on an average of 33 measured specimens.

In addition, there are a number of specimens from offshore waters in the Shell-

\begin{tabular}{|c|c|c|c|c|c|c|c|c|}
\hline No. & $\begin{array}{l}\text { body } \\
\text { length }\end{array}$ & $\begin{array}{c}\text { tail seg. } \\
\text { in } \%\end{array}$ & hook & $\begin{array}{c}\text { ant. } \\
\text { teeth }\end{array}$ & $\begin{array}{l}\text { post. } \\
\text { tee th }\end{array}$ & mat. & TC & loc. \\
\hline 1 & $3.7 \mathrm{~mm}$ & 28.1 & $9-9$ & $2-2$ & $3-3$ & im. & 76.0 & TP \\
\hline 2 & 4.2 & 30.8 & $9-9$ & $3-3$ & $4-4$ & im. & 80.0 & TP \\
\hline 3 & 4.4 & 26.9 & $9-9$ & $2+*-3$ & $5-5$ & im. & 82.8 & TP \\
\hline 4 & 4.9 & 28.9 & $8-8$ & $2-3$ & $4-4$ & im. & 85.7 & SD \\
\hline 5 & 5.1 & 28.2 & $8-8$ & $3-?$ & $5-5$ & im. & 88.2 & TP \\
\hline 6 & 5.1 & 30.4 & $8-9$ & $2-3$ & $5-5$ & im. & 89.9 & SB 5 \\
\hline 7 & 5.2 & 27.5 & $8-9$ & $3--3$ & $4-4$ & im. & 83.3 & SD \\
\hline 8 & 5.3 & 28.0 & $9-9$ & $2-3$ & $5-5$ & im. & 91.4 & $T P$ \\
\hline 9 & 5.3 & 26.8 & $8-9$ & $3-3$ & $7-7$ & $\mathrm{im}$. & 88.2 & $T P$ \\
\hline 10 & 5.5 & 27.1 & $9-9$ & $2-3$ & $5-5$ & im. & 94.3 & $T P$ \\
\hline 11 & 5.7 & 28.4 & $7-8$ & $3-3$ & $5-5$ & im. & 101.6 & $S B 5$ \\
\hline 12 & 5.8 & 29.2 & $9-9$ & $2-3$ & $6-7$ & im. & 89.7 & SB 5 \\
\hline 13 & 5.9 & 27.8 & $8-9$ & $1+*-3$ & $7-7$ & im. & & 585 \\
\hline 14 & 6.0 & 25.8 & $9-9$ & $2-2$ & $5-5$ & im. & 100.0 & $S D$ \\
\hline 15 & 6.3 & 25.7 & $6-7$ & $3-4$ & $7-8$ & im. & 122.8 & $S B 5$ \\
\hline 16 & 6.5 & 27.0 & $7-8$ & $5-5$ & $7-7$ & im. & 87.1 & SB5 \\
\hline 17 & 6.5 & 30.0 & $6-7$ & $5-5$ & $8-8$ & im. & 100.0 & SB 5 \\
\hline 18 & 6.5 & 26.0 & $7-7$ & $4-4$ & $7-7$ & im. & 106.3 & SB 5 \\
\hline 19 & 6.6 & 27.4 & $7-8$ & $3-3$ & $7-7$ & $\mathrm{im}$. & 108.6 & SB 5 \\
\hline 20 & 6.7 & 24.6 & $9-9$ & $2-3$ & $6-6$ & $\mathrm{im}$. & 105.3 & $T P$ \\
\hline 21 & 7.1 & 26.6 & $7-7$ & $5-5$ & $9-9$ & $\mathrm{im}$. & 133.3 & SB 85 \\
\hline 22 & 7.2 & 23.4 & $8-9$ & $3-3$ & $5-5$ & im. & 119.0 & SD \\
\hline 23 & 7.3 & 23.2 & $8-8$ & $4-4$ & $8-8$ & im. & 105.0 & $T P$ \\
\hline 24 & 7.5 & 26.1 & $10-10$ & $3-4$ & $8-8$ & im. & 119.0 & $T P$ \\
\hline 25 & 7.5 & 26.1 & $8-9$ & $4-4$ & $7-7$ & $\mathrm{im}$. & 114.3 & $T P$ \\
\hline 26 & \begin{tabular}{|l|}
9.4 \\
\end{tabular} & 23.6 & $7-9$ & $4-5$ & $8-9$ & med & 134.0 & $S D$ \\
\hline 27 & 10.4 & 25.0 & $8-8$ & $5-5$ & $11-11$ & med & 121.8 & $T P$ \\
\hline 28 & 10.6 & 23.9 & $8-8$ & $4-5$ & $9-10$ & med & 120.4 & SD \\
\hline 29 & 11.0 & 24.9 & $8-8$ & $5-6$ & $11-11$ & med & 100.0 & SO \\
\hline 30 & 11.5 & 23.2 & $8-8$ & $6-6$ & $13-13$ & med & 125.0 & SB I \\
\hline 31 & 11.6 & 22.5 & $8-8$ & $6-6$ & $11-11$ & med & 136.4 & SB I \\
\hline 32 & 11.6 & 24.2 & $8--9$ & $6-6$ & $12-12$ & med & 114.1 & SD \\
\hline 33 & 12.0 & 22.7 & $8-9$ & $7-7$ & $12-14$ & med & 133.3 & SB. 1 \\
\hline 34 & 12.8 & 20.8 & $3-8$ & $4-4$ & $11-12$ & med & 141.7 & SBI \\
\hline
\end{tabular}

Table 6. Armature formulae of $S$. friderici from the blue-green water. * Some torn out. TP...Transpac Exp., SB...Shellback Exp., SD...San Diego. 
back samples, which superficially closely resemble $S$. friderici. Close examination reveals that they do not agree in the armature formulae with the typical $S$. friderici collected from the San Diego region. The anterior and posterior teeth are more abundant in these. Roughly speaking, these chaetognaths can be divided into two groups, one with 7-8 (or 9) hooks (group A) and the other with 5-6 hooks (group B). The armature formulae of the former (group A) resembles somewhat those of S. tenuis. The ratio TC is relatively small, varying from 80 to 91.1 and 86.3 on an average of eleven measured specimens, while in group B it is slightly higher, varying from 88.4 to 114.3 and 96.6 on an average of 13 measured specimens. When the

\begin{tabular}{|c|c|c|c|c|c|c|c|c|}
\hline \multicolumn{2}{|l|}{7} & \multicolumn{6}{|c|}{ Shellbock specimens allied to S.friderici } & \multirow[b]{2}{*}{ loc. } \\
\hline No. & $\begin{array}{l}\text { body } \\
\text { length }\end{array}$ & $\begin{array}{l}\text { tail seg. } \\
\text { in \% }\end{array}$ & hook & $\begin{array}{l}\text { ont. } \\
\text { leeth }\end{array}$ & $\begin{array}{l}\text { post } \\
\text { teeth }\end{array}$ & mat. & $\mathrm{TC}$ & \\
\hline 1 & $6.2 \mathrm{~mm}$ & 29.5 & $7-7$ & $6-6$ & $10-10$ & im. & 85.7 & SB 112 \\
\hline 2 & 6.4 & 25.5 & $7-9$ & $6-6$ & $14-14$ & im. & & SB 109 \\
\hline 3 & 7.2 & 27.3 & $6-6$ & $7-7$ & $14-4$ & med & 88.4 & SB 100 \\
\hline 4 & 7.5 & 27.0 & $6-6$ & $7-7$ & $14-14$ & med & 97.5 & SB 5 \\
\hline 5 & 7.5 & 26.1 & $5-6$ & $7-7$ & $14-14$ & $\mathrm{~m}$. & 95.0 & SB 90 \\
\hline 6 & 7.6 & 27.4 & $7-8$ & $6-6$ & $12-12$ & im. & & SB 5 \\
\hline 7 & 7.7 & 28.0 & $6-6$ & $7-7$ & $14-14$ & im. & & SB 109 \\
\hline 8 & 7.7 & 28.6 & $6-6$ & $7-7$ & $15-17$ & med & & SB 95 \\
\hline 9 & 7.8 & 29.2 & $6-6$ & $7-8$ & $14-15$ & $\mathrm{~m}$. & 100.0 & SB 85 \\
\hline 10 & 78 & 28.3 & $5-6$ & $8-8$ & $15-16$ & $m$ & 93.3 & SB 90 \\
\hline 11 & 7.9 & 26.2 & $6-6$ & $6-6$ & $13-13$ & $\mathrm{im}$. & 100.0 & 58105 \\
\hline 12 & 8.1 & 25.6 & $6-6$ & $7-7$ & $16-16$ & $m$ & 107.5 & SB 50 \\
\hline 13 & 8.1 & 27.2 & $6-6$ & $6-6$ & $13-13$ & $\mathrm{Im}$. & 93.0 & SB 105 \\
\hline 14 & 8.1 & 272 & $8-8$ & $7-7$ & $15-15$ & im & 86.0 & $S B \| 12$ \\
\hline 15 & 8.1 & 28.0 & $6-6$ & $8-8$ & $15-16$ & $m$ & & SB 85 \\
\hline 16 & 8.3 & 29.1 & $6-6$ & $7-7$ & $15-15$ & med & 88.9 & SB 105 \\
\hline 17 & 8.3 & 25.8 & $7-7$ & $4+*-6$ & $12-13$ & $\mathrm{im}$. & 91.1 & SB 105 \\
\hline 18 & 8.5 & 26.9 & $6-6$ & $7-7$ & $14-14$ & $m$ & & SB 5 \\
\hline 19 & 8.5 & 29.2 & $6-6$ & $7-7$ & $16-17$ & $m$ & 913 & $S B \quad 105$ \\
\hline 20 & 8.7 & 29.1 & $6-6$ & $6-7$ & $13-14$ & $\mathrm{im}$. & 90.9 & SB 105 \\
\hline 21 & 8.8 & 26.5 & $6-6$ & $7-8$ & $16-16$ & $m$. & 96.2 & SB I \\
\hline 22 & 8.8 & 29.6 & $6-6$ & $7-7$ & $15-16$ & $\mathrm{im}$. & & SB 90 \\
\hline 23 & 9.4 & 28.5 & $6-6$ & $8-9$ & $18-19$ & $\mathrm{im}$. & 114.3 & SB 109 \\
\hline 24 & 10.0 & 26.6 & $8-8$ & $8-9$ & $16-18$ & $\mathrm{im}$ & 83.3 & SB 118 \\
\hline 25 & 11.1 & 24.1 & $8-8$ & $5+*-9$ & $17+*-19$ & $m$. & 89.2 & SB 109 \\
\hline 26 & 11.4 & 274 & $8-8$ & $9-9$ & $17-18$ & med & 887 & SB 122 \\
\hline 27 & 11.7 & 25.6 & $8-8$ & $7-11$ & $20-22$ & med & 813 & 58109 \\
\hline 28 & 12.0 & 26.1 & $8-8$ & $6+*-11$ & $21-23$ & $m$ & 907 & SB 109 \\
\hline 29 & 13.0 & 25.0 & $8-8$ & $10-10$ & $21-22$ & $\mathrm{~m}$. & 80.0 & SB 109 \\
\hline 30 & 13.2 & 26.1 & $8-8$ & $10-11$ & $24-24$ & $\mathrm{~m}$. & 87.5 & SB109 \\
\hline 31 & 138 & 25.5 & $7-8$ & $10-10$ & $25-25$ & med & 85.7 & SB 109 \\
\hline
\end{tabular}

Table 7. Armature formulae of the Shellback specimens allied to $S$. friderici. * Some torn out. SB...Shellback Exp. 
ratios TC of all of the above-mentioned forms, of course including both typical $S$. tenuis and S. friderici, are plotted on a graph (Fig. 5) and the relative position of values in respective groups are compared, then the idea that group A with 7-8 hooks may be identified as $S$. tenuis, seems possible. Theoretically it is not impossible that $S$. tenuis propagated in some embayments might be drifted out, the attainment of sexual maturity in these might be much retarded by environmental changes so they might grow to such very large size as $13.8 \mathrm{~mm}$, which is evidently an exceptional length for $S$. tenuis. The increase of the body length in waters of lower temperature is not rare in species of chaetognaths. The anterior and posterior teeth might increase

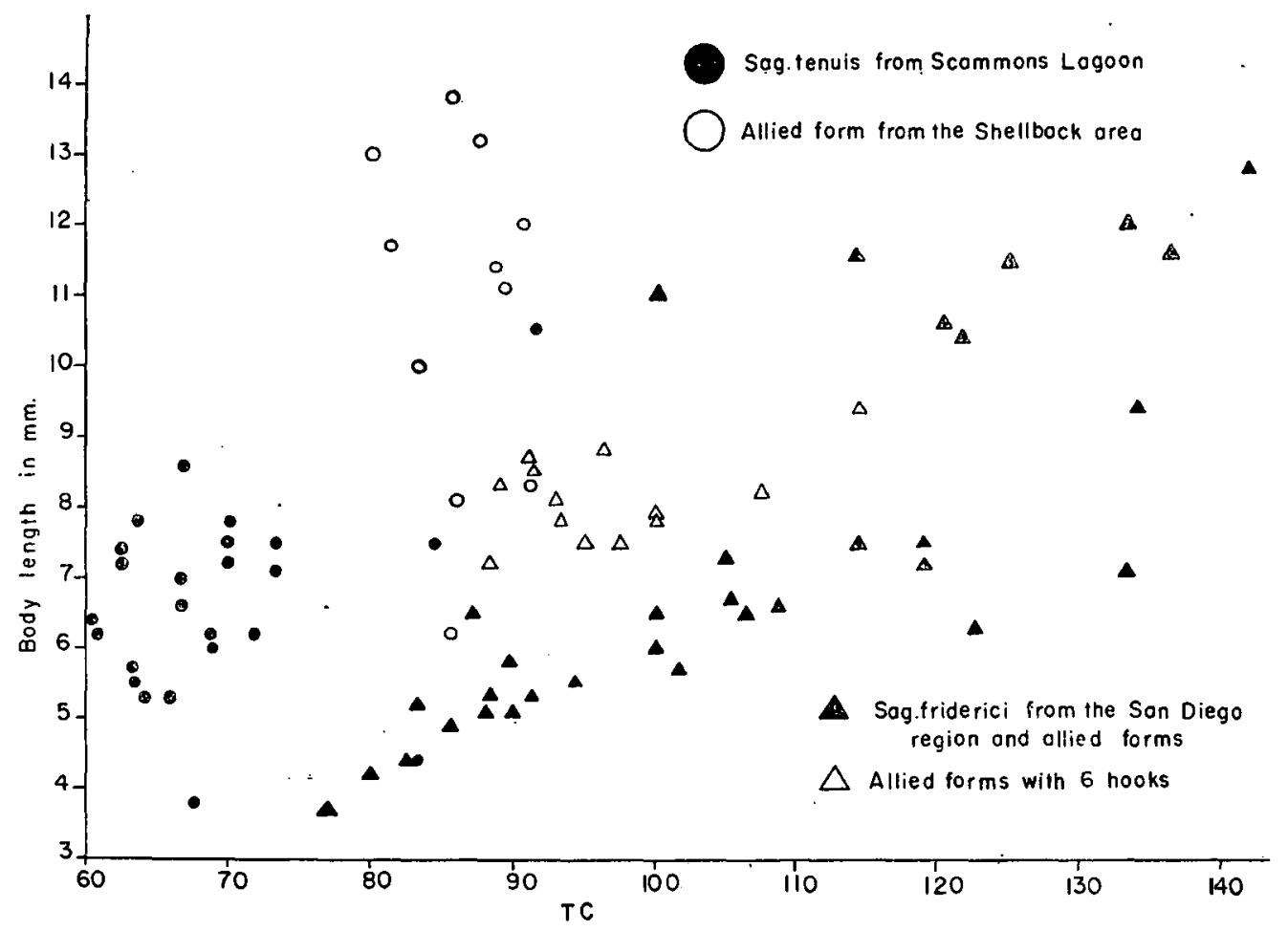

Fig. 5. Ratio TC (anterior part of the posterior fin along the trunk/posterior part of the posterior fin along the caudal segment $\times 100$ ) of Sag. tenuis, Sag. friderici and their allied forms from the Shellback area.

with body length. A flow of water out into the open sea from embayments in tropical area usually results in a remarkable drop in temperature. However, there remains still a gap of considerable width on the graph between the group of the typical S. tenuis and that of group A. Sagitta bipunctata also resembles superficially group A. But it has usually 8-9 (though fluctuating from 7 to 10) hooks and slightly fewer anterior and posterior teeth (Table 8), and also somewhat elongate eye-pigments. In the armature formulae given by Sund (1959b), the number of hooks seems to 
be rather fewer than usual. The body is slightly.stouter than in friderici and the collarette seems to be more conspicuous. For a detailed comparison between these two species, the comprehensive work done by FAure (1952) is available. Sagitta bedoti is also superficially related closely to group A, but this species is most frequently provided with 7 hooks and its fins are marked with conspicuous rayless zones. A careful comparison was also made between group A and Sagitta crassa f. naikaiensis, although the locality of the latter is far removed from the Shellback area. However, the absence of intestinal diverticula in the former denies absolutely a close relationship between these two forms. The distance between the eyes is relatively large in both groups $A$ and $B$, distance/head width $\times 100$ is $36.2-47.5$ (42.3 on an average of 6 measured specimens) in $8.1-13.8 \mathrm{~mm}$ long individuals and this feature seems to increase the superficial similarity between forms $\mathrm{A}$ and $\mathrm{B}$ and $S$. bedoti or S. crassa.

8

Sagitta bipunctato

\begin{tabular}{|c|c|c|c|c|c|c|c|}
\hline No. & $\begin{array}{c}\text { body } \\
\text { length }\end{array}$ & $\begin{array}{c}\text { tail seg } \\
\text { in } \%\end{array}$ & hook & $\begin{array}{c}\text { ant } \\
\text { te eth }\end{array}$ & $\begin{array}{c}\text { post. } \\
\text { te e th }\end{array}$ & maturity & loc \\
\hline 1 & $3.9 \mathrm{~mm}$ & 33.3 & $9-9$ & $3-3$ & $7-7$ & im. & SB 75 \\
\hline 2 & 3.9 & 30.0 & $9-9$ & $5-5$ & $8-8$ & im. & SB 60 \\
\hline 3 & 6.8 & 27.6 & $8-9$ & $7-7$ & $14-15$ & im. & SB 75 \\
\hline 4 & 7.2 & 27.3 & $8-9$ & $5-6$ & $11-11$ & im. & SB 25 \\
\hline 5 & 8.1 & 28.0 & $9-9$ & $6-6$ & $12-12$ & med. & SB 64 \\
\hline 6 & 9.2 & 26.2 & $9-10$ & $7-7$ & $3-15$ & med. & SB 60 \\
\hline 7 & 9.5 & 29.5 & $10-10$ & $7-8$ & $14-15$ & m. & SB71 \\
\hline 8 & 9.8 & 26.7 & $9-9$ & $6-7$ & $15-16$ & m. & SB 71 \\
\hline 9 & 9.8 & 27.3 & $9-9$ & $8-8$ & $15-16$ & m. & SB55 \\
\hline 10 & 9.9 & 26.1 & $10-10$ & $8-8$ & $14-15$ & m. & SB 60 \\
\hline 11 & 9.9 & 26.1 & $8-8$ & $7-9$ & $14-15$ & m. & SB 160 \\
\hline 12 & 10.1 & 27.7 & $10-10$ & $9-9$ & $14-15$ & m. & SB 75 \\
\hline 13 & 11.1 & 25.9 & $10-10$ & $7-7$ & $16-17$ & m. & SB175 \\
\hline
\end{tabular}

Table 8. Armature formulae of S. bipunctata. SB...Shellback Exp.

The ovary at its maximum length reaches to the middle of the anterior fin in group $A$ and to the frontal end of the posterior fin in group B. Group B is very peculiar in having fewer hooks and therefore compared with S. bedoti, S. decipiens and $S$. neodecipiens, both of which are provided most frequently with only 6 hooks. However, the eye-pigments of these two species are elongate and much larger than that of group B. Moreover, the intestinal diverticula are present in these two species. On the other hand, 6 hooks, up to 8 anterior teeth and up to 20 posterior teeth are included in the range of variations found by previous authors in the armature formulae of $S$. friderici. It is evident that $S$. friderici shows a wide range of diversity in the armature formulae according to localities. Consequently it is not strange that some differences are found in the number of hooks and teeth between specimens of S. friderici collected in the San Diego region and those from the Shellback area. 
And the Shellback area itself is very extensive and as a result it is quite possible that there exist different stocks of $S$. friderici, which might show respectively different armature formulae or TC ratios. Therefore it is not improbable that groups A and $B$ represent only different stocks of $S$. friderici, both distinctly differing from the specimens occurring in the San Diego region, because the localities of the groups $A$ and $\mathrm{B}$ are somewhat apart from each other. If the mature seminal vesicles were found in some specimens of these two groups, then the above-mentioned problem would be settled very easily and decidedly. Unfortunately, however, every specimen of groups A and B is devoid of seminal vesicles, hence, at present, only their probable systematic relationships are explained, together with $S$. tenuis and $S$. friderici. As to $S$. tenuis and S. friderici, I can only say that speciation in these two forms seems not to have evolved so far from a common ancestor, but I cannot determine whether the degree of speciation is at the level of species or variety. I am of the opinion that they are not ecological forms of a single species, because intermediate forms are not yet known from the waters showing intermediate characteristics between the tenuis-and friderici-waters.

\section{Sagitta serratodentata tasmanica THOMSON}

(Figs. 6-12, Tábles 9-11)

Thomson (1947): Commonwealth of Australia, Council for Scientific and Industrial Research Bulletin No. 222, pp. 15-17, 1 text-fig.

Sagitta tasmanica...FuRnESTIN (1953 a): Bulletin de I'Institut Océanographique, No. 1025, 39 pp. Furnestin (1953 b): Bulletin des Travaux publiés par la Station d'Aquiculture et de Pàche de Castiglione (Alger), Nouvelle serie, No. 4, p. 25.

FAGETti (1958) : Revista de Biologia Marina (Valparaiso), Vol. VIII, Nos. 1-3, pp. 4648 , text-fig. 7 .

Sagitta sp. (serratodentata group)...BIERI (1959): Limnology and Oceanography, Vol. IV, No. 1, p. 18 , text-fig. 22 .

Many specimens up to $15 \mathrm{~mm}$ from the Shellback area and a single specimen from St. 1 of the Transpac Expedition. Generally speaking, the body appears to be a little more transparent than in S. pacifica; the hooks and the anterior and posterior teeth are yellowish, but stained more faintly than in pacifica and the serration on the hooks is not so conspicuous as in pacifica. The frontal end of the anterior fin begins at about the posterior end of the ventral ganglion. The anterior part of the posterior fin along the trunk is slightly longer than the posterior part along the caudal segment, the fin is broadest at the level posterior to the trunk-tail septum and is provided with a very narrow rayless zone along the trunk in front of the female genital aperture as in pacifica. The collarette is practically absent in all examined specimens. The eye-pigment (Figs. 6 and 10) is elongate, but relatively thicker than in pacifica. For instance, in a perfectly preserved mature specimens of pacifica from the Shellback station SB 50, length of eye-pigment/length of eye $\times 100$ 
was 23.4-24.0 and width of pigment/length of pigment $\times 100$ was $25.0-27.3$, whereas the former was $27.9-34.6$ (30.5 on an average of 4 measurements) and the latter was 32.6-50.0 (43.7 on an average of 4 measurements) in tasmanica. And this difference provides a means of separating immature specimens of pacifica and tasmanica. The ovary at maximum length reaches slightly beyond the middle of the anterior fin and contains up to 30 eggs arranged in two rows, but usually it ends near the anterior end of the posterior fin and contains less than 20 eggs. The seminal vesicle (Figs. $7-8$ ) is situated near the rear end of the posterior fin, being fairly apart from the

9 Sog.serrotodentato tosmonico (1)

\begin{tabular}{|c|c|c|c|c|c|c|c|}
\hline No. & $\begin{array}{c}\text { body } \\
\text { length }\end{array}$ & $\begin{array}{l}\text { tail seg. } \\
\text { in } \%\end{array}$ & hook & $\begin{array}{c}\text { ont. } \\
\text { tee th }\end{array}$ & $\begin{array}{l}\text { post. } \\
\text { tee in }\end{array}$ & maturity & loc \\
\hline 1 & $6.5 \mathrm{~mm}$ & 25.0 & $6-7$ & $6-6$ & $15-16$ & $\mathrm{~m}$ & SB 75 \\
\hline 2 & 6.8 & 26.7 & $5-5$ & $6-6$ & $13-13$ & $m$ & SB68 \\
\hline 3 & 7.0 & 26.9 & $6-6$ & $5-6$ & $12-13$ & $\mathrm{~m}$. & SB 71 \\
\hline 4 & 7.2 & 23.6 & $5-6$ & $6-6$ & $13-13$ & med & SB 71 \\
\hline 5 & 7.6 & 23.1 & $7-7$ & $6-6$ & $14-14$ & $\mathrm{im}$. & SB 90 \\
\hline 6 & 8.1 & 26.4 & $6-6$ & $6-7$ & $13-14$ & $\mathrm{im}$. & SB95 \\
\hline 7 & 8.2 & 23.8 & $6-6$ & $5-5$ & $11-12$ & $m$. & SB 68 \\
\hline 8 & 8.5 & 26.2 & $6-6$ & $6-6$ & $14-15$ & med. & SB 95 \\
\hline 9 & 9.0 & 24.6 & $6-6$ & $7-7$ & $15-16$ & med. & SB 100 \\
\hline 10 & 9.1 & 25.0 & $5-6$ & $7-8$ & $16-17$ & $\mathrm{im}$. & SB 145 \\
\hline 11 & 9.2 & 24.6 & $6-6$ & $6-6$ & $11-12$ & med & SB132 \\
\hline 12 & 9.3 & 23.1 & $5-5$ & $7-7$ & $15-16$ & $m$ & SB 95 \\
\hline 13 & 9.4 & 25.5 & $6-6$ & $5-6$ & $14-15$ & med. & SB 85 \\
\hline 14 & 9.4 & 24.1 & $6-6$ & $6-7$ & $16-16$ & $m$ & $S B 112$ \\
\hline 15 & 9.8 & 23.3 & $6-6$ & $7-7$ & $14-15$ & & SB 170 \\
\hline 16 & 9.8 & 26.7 & $6-6$ & $6-7$ & $14-15$ & med. & 5885 \\
\hline 17 & 9.8 & 25.3 & $6-6$ & $5-6$ & $13-13$ & $m$ & SB 90 \\
\hline 18 & 9.9 & 25.7 & $6-6$ & $7-7$ & $15-15$ & Im. & SB 50 \\
\hline 19 & 9.9 & 21.1 & $6-6$ & $7-7$ & $15-16$ & $\mathrm{~m}$. & SB 85 \\
\hline 20 & 9.9 & 23.5 & $6-6$ & $7-7$ & $15-16$ & $\mathrm{~m}$. & SB 180 \\
\hline 21 & 10.1 & 25.6 & $6-6$ & $6-7$ & $13-14$ & $\mathrm{im}$. & SB 90 \\
\hline 22 & 101 & 231 & $6-7$ & $7-7$ & $13-13$ & med. & SB137 \\
\hline 23 & 10.2 & 23.6 & $6-6$ & $7-7$ & $+6-17$ & $\mathrm{~m}$. & SB 35 \\
\hline 24 & 10.3 & 241 & $6-6$ & $7-7$ & $17-18$ & $\mathrm{~m}$. & SB 50 \\
\hline 25 & 10.3 & 252 & $6-6$ & $7-7$ & $16-17$ & $\mathrm{im}$. & SB 35 \\
\hline 26 & 10.4 & 225 & $6-6$ & $6-6$ & $15-15$ & & SB 30 \\
\hline 27 & 10.5 & 24.8 & $6-6$ & $8-8$ & $15-17$ & m. & SB 35 \\
\hline 28 & 10.5 & 23.5 & $6-6$ & $7-8$ & $19-19$ & $\mathrm{~m}$. & SB109 \\
\hline 29 & 10.6 & 26.4 & $6-6$ & $5-7$ & $13-14$ & im. & SB 35 \\
\hline 30 & 10.6 & 23.9 & $5-5$ & $7-8$ & $16-17$ & $\mathrm{~m}$. & SB 35 \\
\hline 31 & 10.7 & 24.8 & $6-6$ & $6-7$ & $15-15$ & $\mathrm{im}$. & SB 35 \\
\hline 32 & 107 & 25.5 & $6-6$ & $6-7$ & $\mid 6-17$ & $\mathbf{m}$. & SB 50 \\
\hline
\end{tabular}

Table 9-1. Armature formulae of S. serratodentata tasmanica. - SB -..Shellback Exp. 
caudal fin, although in very early stages of the development (16 in Fig. 7), it may be separated considerably from both of the posterior and tail fins. It is elongate, and slightly swollen anteriorly in early stages, but becomes oval at maturity. A small prominence may be produced at maturity at the antero-lateral corner (21-26 in Fig. 7), where the glandular tissue is located, and the rupture occurs just around this prominence (27 in Fig. 7 and Fig. 8 ); evidently protandric. The intestinal diverticula absent. Rows of anterior teeth meet each other in an acute angle. The armature formulae of some individuals (for instance Nos. 3, 7, 11, 17, 22 and 45 in Table 9) from the Shellback area resemble those of typical serratodentata atlantica

9 Sag.serratodentata tosmanica (2)

\begin{tabular}{|c|c|c|c|c|c|c|c|}
\hline No. & $\begin{array}{l}\text { body } \\
\text { length }\end{array}$ & \begin{tabular}{|l} 
tail seg. \\
in $\%$
\end{tabular} & hook & $\begin{array}{c}\text { ant. } \\
\text { te e ih }\end{array}$ & $\begin{array}{l}\text { post. } \\
\text { teeth }\end{array}$ & moturity & loc. \\
\hline 33 & 10.8 & 21.7 & $5-6$ & $6-6$ & $12-14$ & $\mathrm{~m}$. & SB 80 \\
\hline 34 & 10.8 & 24.1 & $6-6$ & $6-7$ & $15-15$ & $\mathrm{~m}$. & SB 35 \\
\hline 35 & 10.9 & 25.6 & -6 & $7-7$ & $\mid 5-15$ & 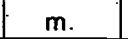 & SB 35 \\
\hline 36 & 10.9 & 24.0 & $5-5$ & $7-7$ & $15-17$ & $\mathrm{~m}$. & SB 115 \\
\hline 37 & 11.0 & 24.7 & $6-6$ & $7-7$ & $15-15$ & $\mathrm{im}$. & SB 35 \\
\hline 38 & 11.1 & 23.5 & $5-6$ & $7-7$ & $14-14$ & med. & SB 130 \\
\hline 39 & 11.1 & 22.4 & $7-7$ & $7-7$ & $14-15$ & & SB 1 \\
\hline 40 & 11.2 & 24.4 & $5-5$ & $7-8$ & $16-.17$ & $\mathrm{~m}$. & SB 105 \\
\hline 41 & 11.4 & 21.7 & $5-5$ & $6-7$ & $17-18$ & $\mathrm{~m}$. & $S B 137$ \\
\hline 42 & 11.4 & 22.9 & $6-6$ & $7-7$ & $14-14$ & med. & SB 137 \\
\hline 43 & 11.7 & 25.0 & $6-6$ & $7-7$ & $14-16$ & med. & SB 35 \\
\hline 44 & 11.8 & 23.1 & $6-6$ & $7-7$ & $16-16$ & $\mathrm{~m}$. & $S E 137$ \\
\hline 45 & 12.0 & 24.3 & $6-7$ & $6-7$ & $13-13$ & $\mathrm{im}$. & $S B 132$ \\
\hline 46 & 12.1 & 23.7 & $7--7$ & $5-5$ & $13-15$ & $\mathrm{~m}$. & SB 137 \\
\hline 47 & 12.2 & 25.1 & $6-6$ & $7-8$ & $18-18$ & med. & SB105 \\
\hline 48 & 12.2 & 25.1 & $6-6$ & $8-8$ & $17-17$ & med. & $S B I I 2$ \\
\hline 49 & 12.2 & 25.1 & $6-7$ & $7-7$ & $14-14$ & med. & $S B 132$ \\
\hline 50 & 12.2 & & $5-5$ & $7-7$ & $21-21$ & & SB 137 \\
\hline 51 & 12.4 & 23.7 & $5-5$ & $4+4-7$ & $15-15$ & 11 & SB 118 \\
\hline 52 & 12.5 & 21.9 & $5-6$ & $10-10$ & $22-22$ & $\mathrm{~m}$. & SB137 \\
\hline 53 & 12.6 & 23.7 & $6-6$ & $6-7$ & $16-17$ & med. & SB:15 \\
\hline 54 & 12.7 & 24.1 & $6-6$ & $5-6$ & $16-16$ & med. & SBII5 \\
\hline 55 & 12.7 & 23.1 & $6-6$ & $7-8$ & $17-18$ & $\mathrm{im}$. & SB 137 \\
\hline 56 & 12.7 & 24.1 & $7-7$ & $6-7$ & $15-15$ & $\mathrm{~m}$. & SB I \\
\hline 57 & 13.0 & 23.0 & $5-5$ & $7-7$ & $15-16$ & $\mathrm{~m}$. & SB109 \\
\hline 58 & 13.1 & 22.3 & $6-6$ & $7-7$ & $16-17$ & $\mathrm{~m}$. & SB 118 \\
\hline 59 & 13.2 & 23.6 & $6-6$ & $5-6$ & $13-14$ & $\mathrm{~m}$. & SB I \\
\hline 60 & 13.3 & 23.9 & $5-5$ & $8-8$ & $20-21$ & med. & SB 112 \\
\hline 61 & 14.3 & 22.8 & $6-6$ & $8-8$ & $17-18$ & m. & SBI22 \\
\hline 62 & 14.7 & 23.5 & $6-6$ & $8-8$ & $15-15$ & med. & SB122 \\
\hline 63 & 15.0 & 21.7 & $5-5$ & $7-7$ & $16-17$ & m. & $S B 132$ \\
\hline
\end{tabular}

Table 9-2. Armature formulae of S. serratodentata tasmanica. * Some torn out. SB...Shellback Exp. 


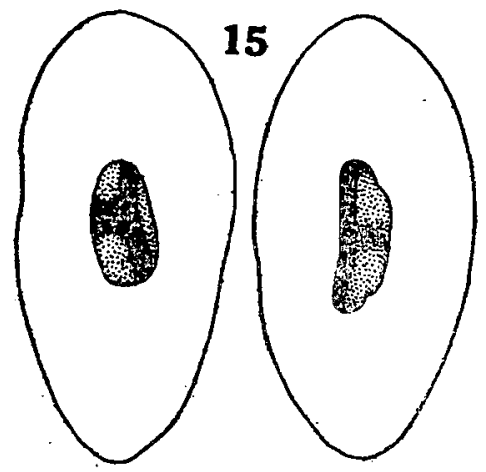

Fig. 6. Sagitta serratodentata tasmanica THomson. Eyes of a 10.3 and $10.7 \mathrm{~mm}$ long individuals, magnified.

10 Sog.serratodentata pacifica

\begin{tabular}{|c|c|c|c|c|c|c|c|}
\hline No & $\begin{array}{c}\text { body } \\
\text { length }\end{array}$ & $\begin{array}{c}\text { tailseg. } \\
\text { in } \%\end{array}$ & hook & $\begin{array}{c}\text { ant. } \\
\text { te eth }\end{array}$ & $\begin{array}{c}\text { post. } \\
\text { te eth }\end{array}$ & maturity & loc. \\
\hline 1 & $8.4 \mathrm{~mm}$ & 26.4 & $7-7$ & $6-6$ & $13-13$ & $\mathrm{~m}$. & SB 50 \\
\hline 2 & 8.5 & 27.7 & $6-6$ & $7-7$ & $13-13$ & $\mathrm{~m}$. & SB 50 \\
\hline 3 & 8.6 & 26.3 & $7-7$ & $7-7$ & $12-12$ & $\mathrm{~m}$. & SB 50 \\
\hline 4 & 9.0 & 23.9 & $6-6$ & $10-11$ & $19-21$ & med. & SB 64 \\
\hline 5 & 9.4 & 24.1 & $7-7$ & $10-10$ & $18-18$ & med. & SB 90 \\
\hline 6 & 9.9 & 25.0 & $6-6$ & $8-9$ & $15-18$ & med. & SB 90 \\
\hline 7 & 10.1 & 25.8 & $6-6$ & $10-11$ & $19-20$ & m. & SB 35 \\
\hline 8 & 10.4 & 26.3 & $6-7$ & $9-9$ & $18-19$ & im. & SB 35 \\
\hline 9 & 10.6 & 25.2 & $6-6$ & $9-10$ & $20-21$ & m. & SB 35 \\
\hline 10 & 10.9 & 25.6 & $5-6$ & $9-10$ & $21-22$ & m. & SB 35 \\
\hline 11 & 11.0 & 25.4 & $6-7$ & $8-9$ & $20-20$ & m. & SB 35 \\
\hline 12 & 11.1 & 23.5 & $5-6$ & $11-11$ & $22-23$ & m. & TP \\
\hline 13 & 11.2 & 26.0 & $6-6$ & $11-11$ & $21-21$ & m. & SB 35 \\
\hline 14 & 11.4 & 26.1 & $6-6$ & $10-10$ & $18-18$ & m. & SB 105 \\
\hline
\end{tabular}

11 Sag.serratodentata pseudoserratodentato

\begin{tabular}{|c|c|c|c|c|c|c|c|}
\hline No. & $\begin{array}{c}\text { body } \\
\text { length }\end{array}$ & $\begin{array}{c}\text { tail seg. } \\
\text { in } \%\end{array}$ & hook & $\begin{array}{c}\text { ant. } \\
\text { teeth }\end{array}$ & $\begin{array}{c}\text { post. } \\
\text { teeth }\end{array}$ & maturity & loc \\
\hline 1 & $7.0 \mathrm{~mm}$ & 28.0 & $6-6$ & $4-4$ & $9-12$ & $\mathrm{~m}$. & SB 215 \\
\hline 2 & 7.6 & 27.4 & $6-6$ & $5-5$ & $11-11$ & $\mathrm{~m}$. & SB215 \\
\hline 3 & 7.6 & 27.4 & $6-6$ & $6-6$ & $13-13$ & $\mathrm{~m}$. & SB 215 \\
\hline 4 & 7.7 & 28.0 & $6-6$ & $6-6$ & $12-13$ & $\mathrm{~m}$. & $\mathrm{SB} 215$ \\
\hline 5 & 7.7 & 28.0 & $6-6$ & $5-6$ & $12-12$ & $\mathrm{~m}$. & $\mathrm{SB} 215$ \\
\hline 6 & 8.2 & 27.8 & $6-7$ & $7-7$ & $14-14$ & med. & SB 80 \\
\hline 7 & 9.8 & 25.3 & $6-6$ & $7-7$ & $13-13$ & im. & SB 50 \\
\hline 8 & 9.8 & 24.0 & $6-6$ & $6-7$ & $12-13$ & im. & SB 50 \\
\hline 9 & 10.8 & 26.5 & $6-6$ & $6-7$ & $14-14$ & im. & SB50 \\
\hline
\end{tabular}

Tables 10-11. Armature formulae of S. serratodentata pacifica (10) and S. serratodentata pseudoserratodentata (11). SB..Shellback Exp. 


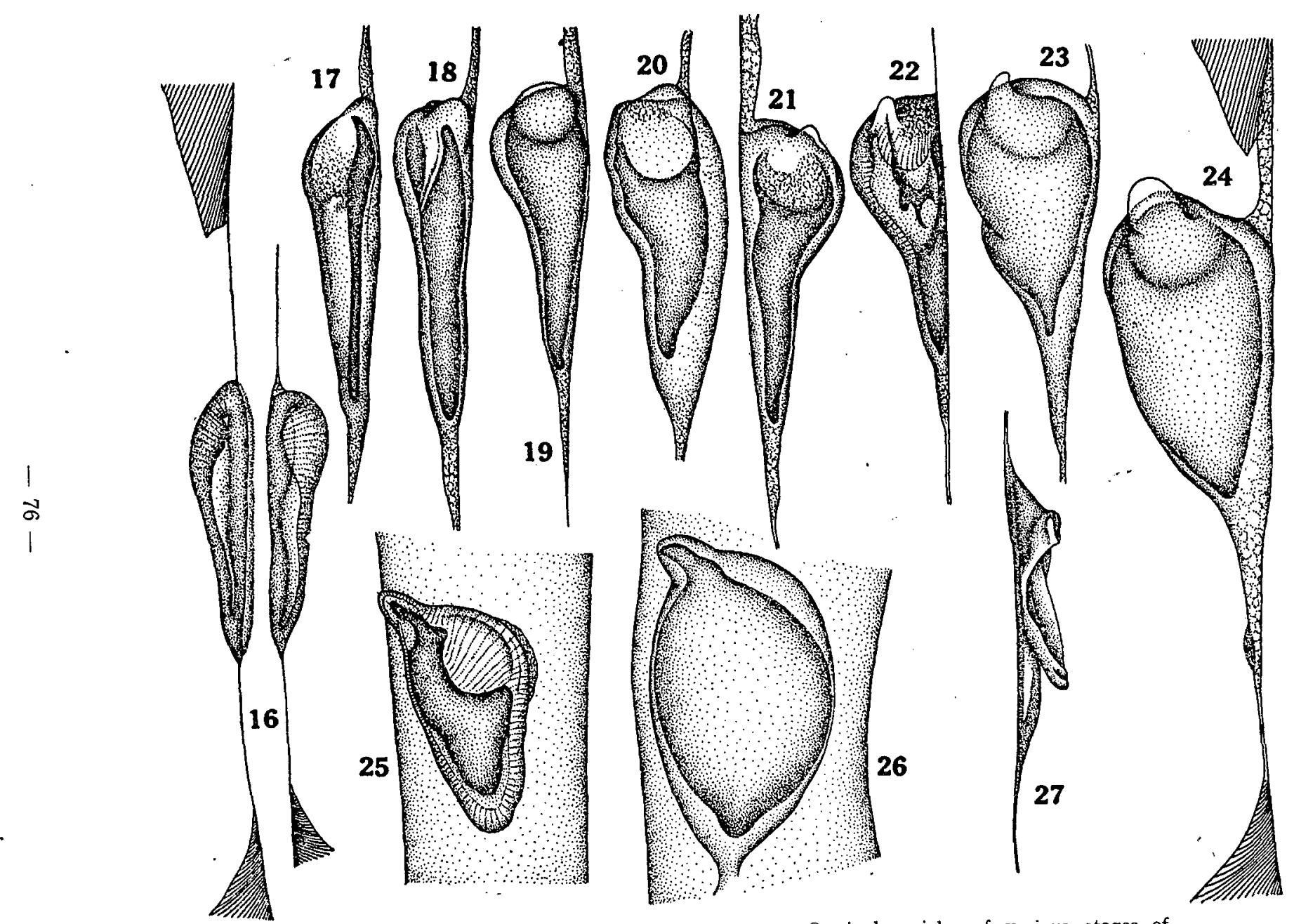

Fig. 7. Sagitta serratodentala tasmanica THOMson. Seminal vesicles of various stages of development, arranged in the order of maturity, $\times 125.16-\mathrm{SB} 132,20$-dorsal; 21 , 22 -SB 137; 23, 24-dorsal; 25, 26-right vesicles, SB 137; 27-ruptured. 
and those of some others (for instance Nos. 28, 47, 50, 52 and 60 in the same table) are related closely to those of typical pacifica. Since some of these unusual specimens are provided with seminal vesicles of the typical tasmanica-form, it is unlikely that some specimens of atlantica and pacifica were mistaken for tasmanica. The number of posterior teeth is most frequently 13-17 (Fig. 9) and this is evidently an intermediate between those of atlantica and pacifica.

Remarks: For comparison with the present subspecies, some specimens of pacifica and pseudoserratodentata from the Shellback area were examined closely. In pacifica,

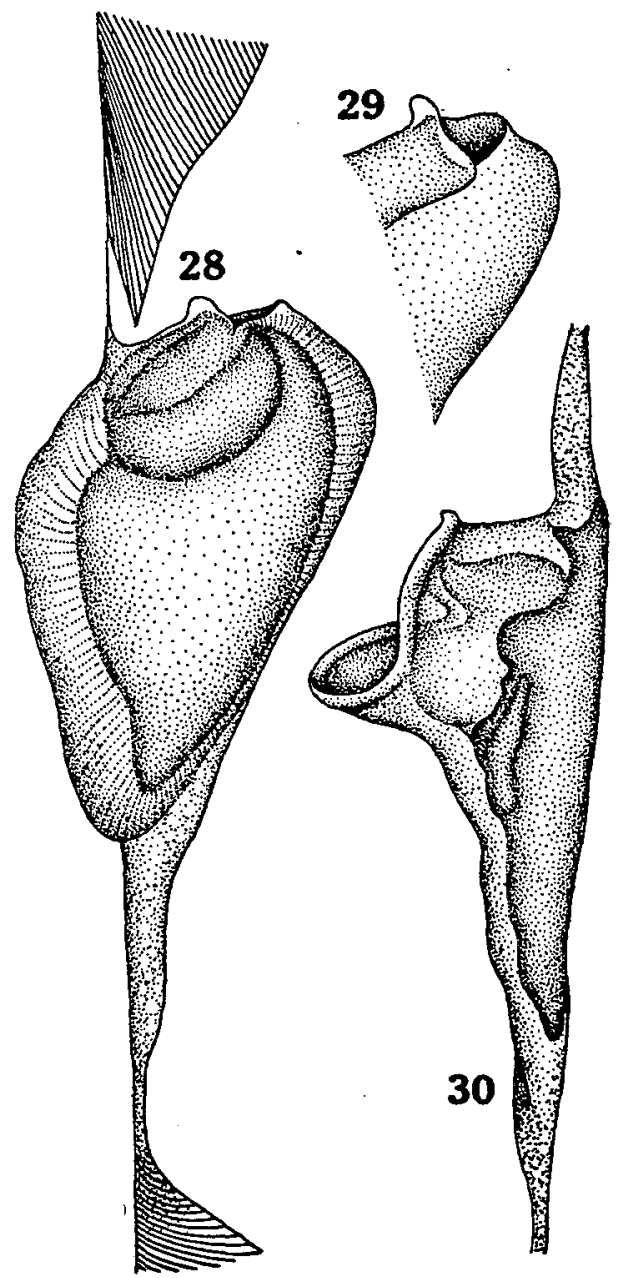

Fig. 8. Sagitta serratodentata tasmanica THOMson. Seminal vesicles of a $14 \mathrm{~mm}$ long individual (tail seg. $24.7 \%, 6-6 \frac{7-8}{18-18}$ ). $\times 125$. 28-left vesicle, just rupturing; 29-ruptured portion; 30 -right vesicle, fully ruptured. 
the collarette is usually distinct, though not voluminous. The ovary may reach anteriorly to about the ventral ganglion and contains up to 40 eggs at maximum. There are very many individuals in which the seminal vesicles projected out obliquely anteriorly. The armature formulae of 14 specimens with mature seminal vesicles are given in Table 10. In this table, the occurrence of three specimens at SB 50 with exceptionally few teeth (Nos. 1-3) is noteworthy. The teeth are so few that at first these three specimens were mistaken for atlantica. The structure of the seminal vesicle is, however, of the typical pacifica-form as shown in the figure (Fig. 10). Specimens Nos. 4 and 12 are striking in that the seminal vesicles have no

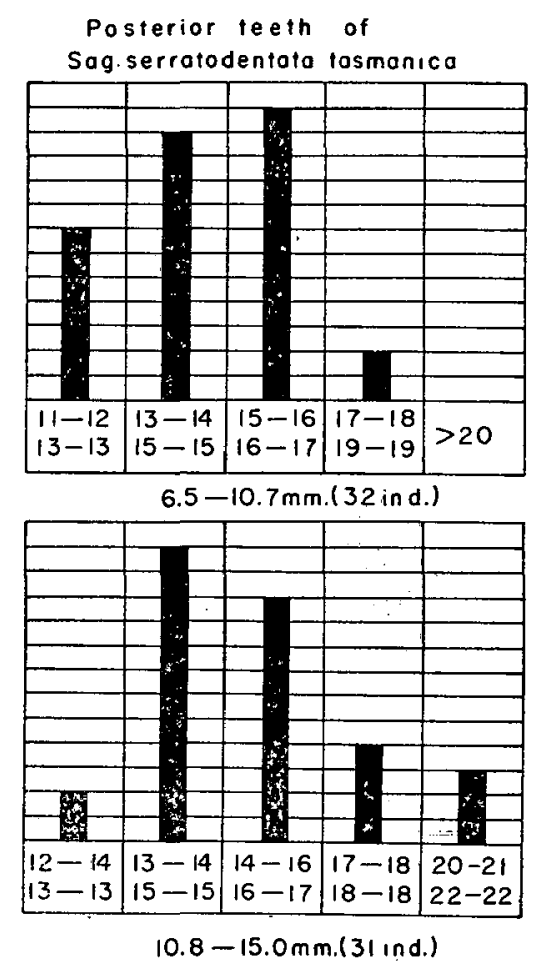

Fig. 9. Sagitta serratodentata tasmanica THOMSON. Fluctuation of the number of posterior teeth of specimens from the Shellback area.

teeth ; very probably they are mal-formed individuals of pacifica, because the cephalic teeth are numerous enough for pacifica and the vesicles are projected out just as in typical pacifica. Some authors doubt the validity of pseudoserratodentata. Indeed, the armature formulae of this form conforms well to those of atlantica. But the shape of the mature seminal vesicle (Fig. 11) is 'quite different between the two, also the body length of mature specimens is considerably less in pseudoserratodentata than in atlantica. In the Shellback specimens, the ovaries reach neach the middle of the anterior fin and contain up to 20 eggs in each at maturity. The serration of 
hooks in pseudoserratoddntata is the least conspicuous of the three forms. A specimen from SB 130 has seminal vesicles which have each two prominences at the anterior end (Fig. 12) and hence at first this was considered to be atlantica, but the situation and the shape of the prominences differ slightly from those of typical atlantica, in which they are situated at the antero-lateral corner; rather the situation resembles that of a prominence of the seminal vesicle in tasmanica. Thus, it is possible that this specimen represents an unusual individual of tasmanica.

Sagitta selkirki FAGETTI from Chilean waters around the Juan Fernandez Archipelago resembles most closely tasmanica in the appearance of the seminal

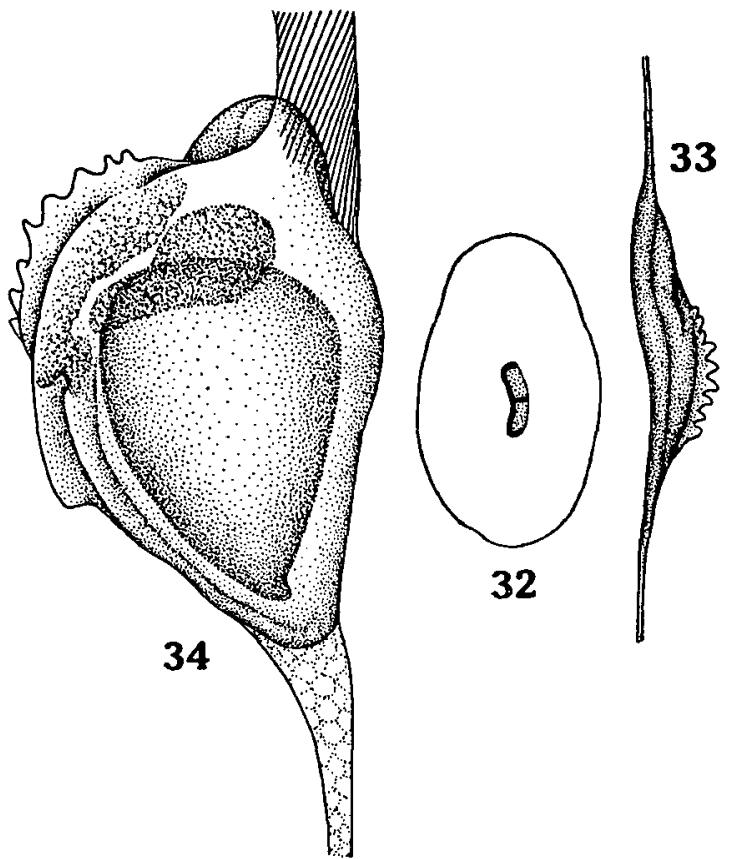

Fig. 10. Sagitta serratodentata pacifica TокIOKA. A $8.5 \mathrm{~mm}$ long individual (No. 2 of the Table) from SB 50. 32-eye, magnified; 34-left vesicle, $\times 125 ; 33$-immature right vesicle of a specimen from SB 30 . $\times 125$.

vesicle, but the constant occurrence of seven hooks and fewer posterior teeth, besides the comparatively small body length of mature individuals, seem to be unique for this form. On the other hand, the dental formulae, which are related closely with those of selkirki as given by FAGETTI, can be seen at some places of Table 9 to show the armature formulae of tasmanica from the Shellback area. So, it is not impossible that selkirki represents a peculiar stock of tasmanica as do three specimens of pacifica from SB 50 (p. 370). Therefore, I hesitate to judge conclusively the validity of this species at present. Lastly, here arises a question as to whether the forms, 


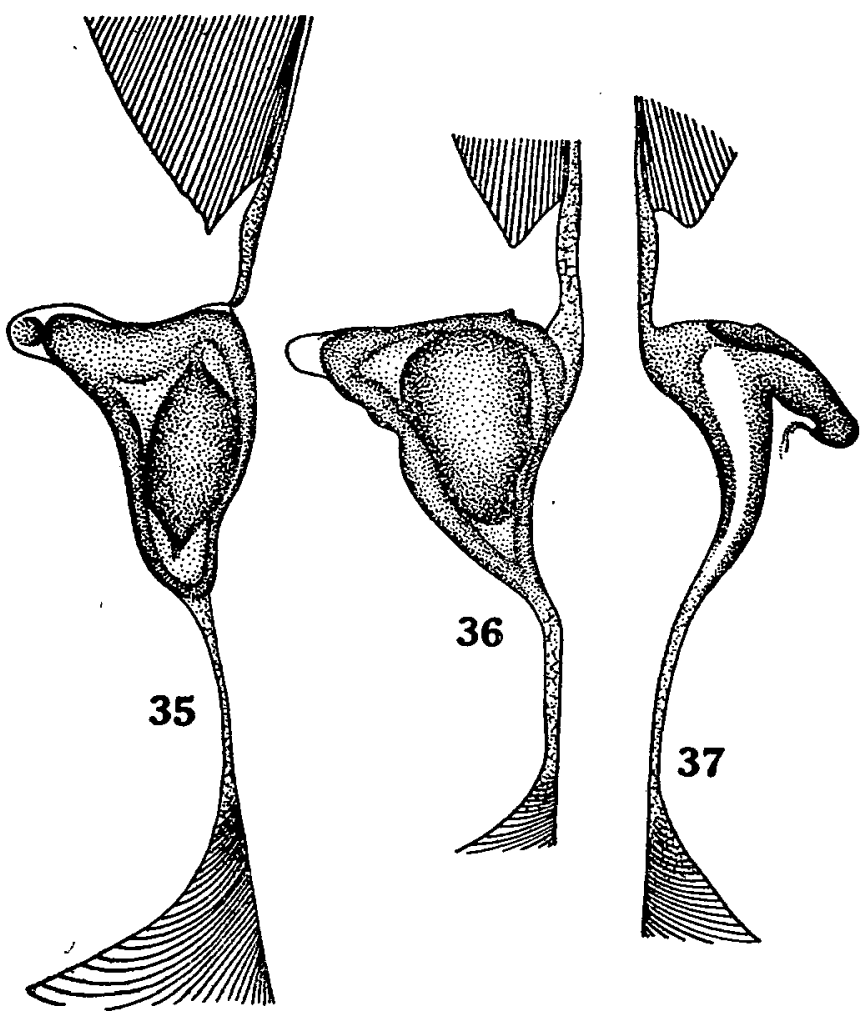

Fig. 11.

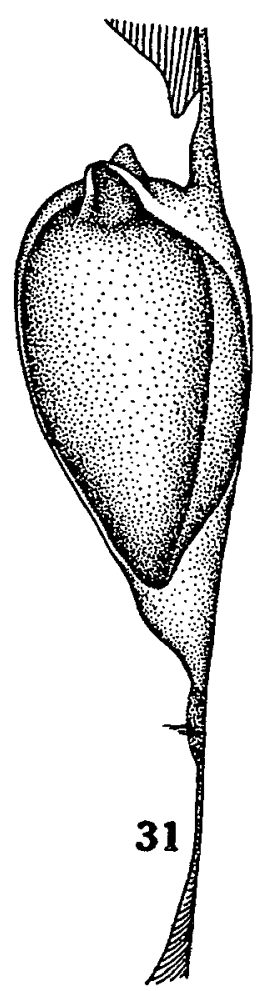

Fig. 12.

Fig. 11. Sagitta serratodentata pseudoserratodentata ToKIoKA. Seminal vesicles, $\times 125$. $35-7.7 \mathrm{~mm}$ long individual from SB $215,36-$ right vesicle of a $7.6 \mathrm{~mm}$ long individual from SB 215, 37ruptured left vesicle of the same specimen.

Fig. 12. ?Sagitta serratodentata atlantica. Left seminal vesicle of a specimen from SB 130 . $\times 125$.

atlantica, pacifica, tasmanica and pseudoserratodentata should be ranked as species or subspecies. Since there are several distinct and important characteristics common to all of these forms, the serrated hooks, the remarkably elongate eye-pigment, the situation of seminal vesicles and the existence of a conspicuous swelling at the middle of the vas deferens besides the absence of intestinal diverticula and the general structure of the fins, the relation between these forms seems to be much closer than that found between other species. Hence, I am inclined to treat the forms as subspecies of a single species Sagitta serratodentata, though in some parts of this paper, especially in tables, I listed them as species in order to conserve space.

4. Sagitta neglecta AIDA and its allies

(Figs. 13-16, Tables 12-15) 
(1) Sagitta neglecta Arda (Fig. 13, Table 12): This species is extremely rare in the eastern Pacific as noted already by BIERI (1959) and SUND (1959b), though it occurs rather commonly in the western part of the North Pacific. Thus, it seems necessary to compare the specimens from both sides of the North Pacific and to ascertain the identity of the eastern specimens with the western. The armature formulae of the Shellback specimens given in Table 12 conform well to those of

\begin{tabular}{|c|c|c|c|c|c|c|c|}
\hline \multicolumn{2}{|l|}{12} & \multicolumn{3}{|c|}{ Sagitto } & \multirow[b]{2}{*}{$\begin{array}{l}\text { post. } \\
\text { teeth }\end{array}$} & \multirow[b]{2}{*}{ maturity } & \multirow[b]{2}{*}{$10 \mathrm{c}}$. \\
\hline No. & $\begin{array}{c}\text { body } \\
\text { length }\end{array}$ & $\begin{array}{l}\text { tail seg. } \\
\text { in } \%\end{array}$ & hook & $\begin{array}{c}\text { ant. } \\
\text { te e th }\end{array}$ & & & \\
\hline 1 & $4.6 \mathrm{~mm}$ & 29.6 & $8-8$ & $5-5$ & $11-11$ & im. & SB 60 \\
\hline 2 & 4.8 & 29.7 & $7-8$ & $5-6$ & $12-13$ & $\mathrm{im}$. & SB 55 \\
\hline 3 & 5.6 & 31.4 & $7-7$ & $5-6$ & $14-15$ & $\mathrm{im}$. & SB 55 \\
\hline 4 & 5.9 & 30.0 & $7-7$ & $5-6$ & $13-14$ & $\mathrm{im}$. & SB 55 \\
\hline 5 & 6.0 & 31.5 & $8-8$ & $6-6$ & $13-14$ & $\mathrm{im}$. & SB 80 \\
\hline 6 & 6.0 & 29.0 & $8-8$ & $5-5$ & $14-15$ & im. & SB 170 \\
\hline 7 & 6.2 & 30.2 & $7-7$ & $6-7$ & $15-15$ & $\mathrm{im}$. & SB 55 \\
\hline 8 & 6.2 & 34.4 & $7-7$ & $6-7$ & $15-16$ & $\mathrm{im}$. & SB 60 \\
\hline 9 & 6.5 & 34.0 & $6-7$ & $7-7$ & $16-17$ & $\mathrm{im}$. & SB 60 \\
\hline 10 & 6.5 & 33.0 & $7-7$ & $6-6$ & $14-14$ & $m \in d$. & SB 60 \\
\hline 11 & 6.8 & 33.3 & $7-8$ & $6-7$ & $16-16$ & & SB170 \\
\hline 12 & 6.8 & 31.4 & $7-7$ & $5-6$ & $13-13$ & $\mathrm{~m}$. & SBI95 \\
\hline 13 & 6.9 & 30.2 & $8-8$ & $6-6$ & $17-18$ & $\mathrm{im}$. & SB 60 \\
\hline 14 & 6.9 & 28.3 & $7-8$ & $6-7$ & $16-16$ & & 58170 \\
\hline 15 & 7.2 & 30.9 & $7-8$ & $2+*-7$ & $17-17$ & $\mathrm{~m}$. & SB 109 \\
\hline 16 & 7.3 & 32.1 & $6-6$ & $6-6$ & $17-17$ & $m$. & SB 68 \\
\hline 17 & 7.5 & 32.2 & $8-8$ & $4+*-6$ & $16-17$ & $\mathrm{~m}$. & SB 68 \\
\hline$* 18$ & 7.5 & 28.7 & $0+*-3+*$ & $5-6$ & $7-10$ & med. & SB 50 \\
\hline 19 & 7.7 & 29.4 & $7-7$ & $7-7$ & $17-17$ & & SB 170 \\
\hline 20 & 8.1 & 28.0 & $7-8$ & $7-8$ & $18-18$ & $\mathrm{~m}$. & SBI7O \\
\hline
\end{tabular}

13 Sogitio oceanio

\begin{tabular}{|c|c|c|c|c|c|c|c|}
\hline No. & $\begin{array}{c}\text { body } \\
\text { length }\end{array}$ & $\begin{array}{c}\text { tail seg. } \\
\text { in } \%\end{array}$ & hook & $\begin{array}{c}\text { ant. } \\
\text { te e th }\end{array}$ & $\begin{array}{c}\text { post. } \\
\text { te eth }\end{array}$ & moturity & $10 \mathrm{c}$. \\
\hline 1 & $4.3 \mathrm{~mm}$ & 31.8 & $7-7$ & $4-5$ & $11-12$ & m. & EQPS28 \\
\hline 2 & 4.7 & 31.5 & $7-8$ & $5-5$ & $13-13$ & m. & EQPS28 \\
\hline 3 & 4.8 & 32.4 & $7-7$ & $4-5$ & $12-12$ & m. & EQPS28 \\
\hline
\end{tabular}

Tables 12-13. Armature formulae of S. neglecta (12) and S. oceania (13).

* Some torn out. SB...Shellback Exp.

typical forms from the western Pacific. The general structure of the body agrees closely in these two groups of specimens. For these reasons, S. neglecta undoubtedly occur also in the Shellback area. In specimens examined from this area, the ovary may reach to the anterior end of the ventral ganglion. Individual No. 18 in Table 12 (Fig. 13) is very peculiar in that the posterior teeth are much fewer and the 
intestinal diverticula are not distinct. The anterior fin begins at the posterior end of the ventral ganglion, the posterior fin is slightly longer than the anterior, equally divided on the trunk and the caudal segment and broadest at the level posterior to the trunk-tail septum; the constriction of the body at this septum is not remarkable. Rayless zones were not found on either fin. A thin collarette is present around the neck. The ovary at medium maturity reaches to the front end of the posterior fin. The seminal vesicle (39) is situated near the rear end of the posterior fin; its shape
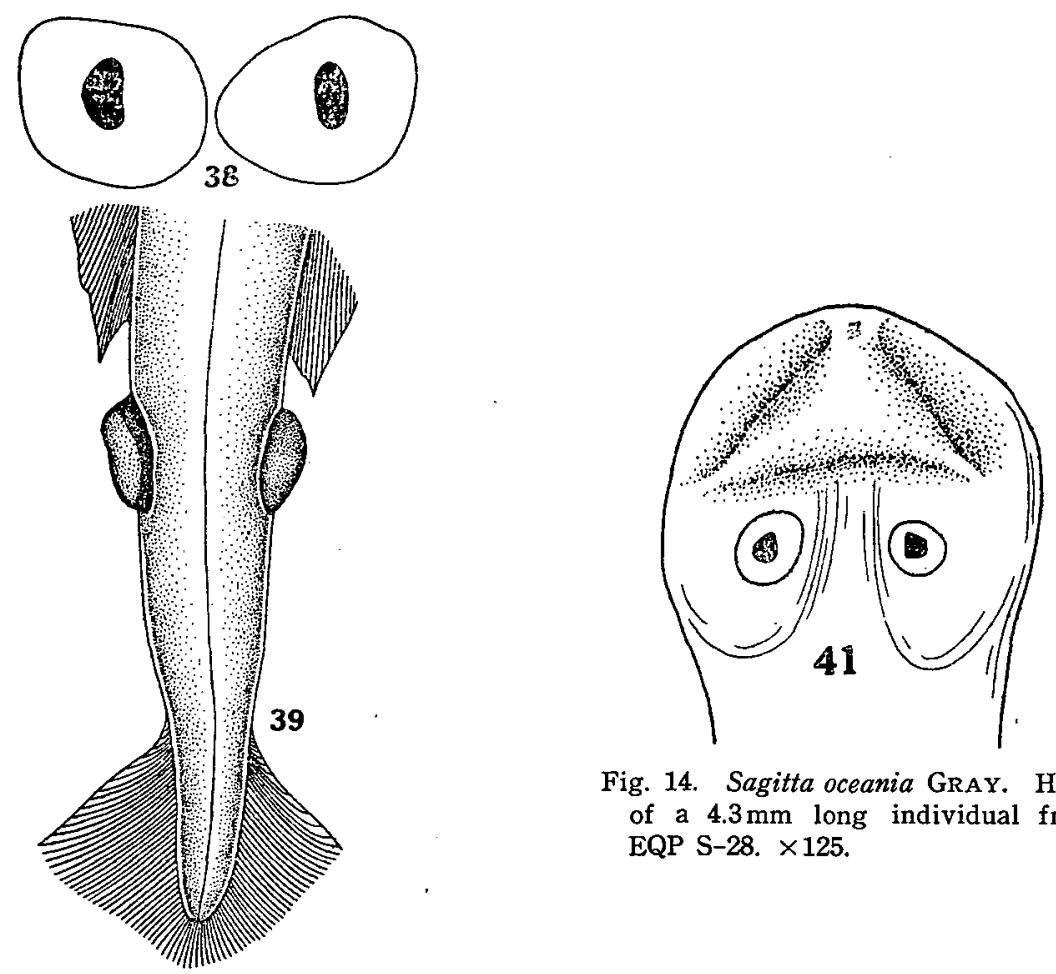

Fig. 14. Sagitta oceania GrAy. Head of a $4.3 \mathrm{~mm}$ long individual from EQP S-28. $\times 125$.

Fig. 13. A problematic specimen (No. 18 of the Table), treated here provisionally as Sagitta neglecta AIDA, from SB 50. 38-eyes, magnified; $39-$ seminal vesicles, dorsal. $\times 73$.

resembles that of Sagitta oceania. Eye-pigment (38) oval, length of pigment/length of eye $\times 100$ is $39.4-43.8$, width of pigment/length of pigment $\times 100$ is $53.8-60.7$. The fewer number of hooks is evidently attributable to some injury. The armature formula, the situation of the seminal vesicle, and the indistinctness of the intestinal diverticula suggest a possible identity of this specimen with Sagitta setosa from the European waters. However, since the shape of the corona ciliata was not ascertained, and the anterior fin seems too long for setosa and moreover the locality is so far 
removed from the European waters, one hesitates to treat the specimen as setosa. Rather, it is treated here provisionally as an unusual individual of neglecta pending further detail study of specimens in better state of preservation.

(2) Sagitta oceania Gray (Figs. 14-15, Table 13): Six specimens up to $4.8 \mathrm{~mm}$ were found in the sample from EQP-S 28. The anterior fin begins at the posterior end of the ventral ganglion; the posterior fin is longer than the anterior, nearly equally divided on the trunk and the tail segment and broadest at the level posterior to the trunk-tail septum. Rayless zone absent in both fins, although rays are very sparse in a small part near the frontal end. The collarette is practically absent, eye-pigment (41) is roundish and very large. The ovary reaches slightly beyond the posterior end of the anterior fin, eggs are unequal in size. The seminal vesicles are situated nearer the posterior fin than the caudal fin; distance to posterior fin/distance to caudal fin is 0.32 to 0.70 , being 0.48 on an average of 4 measurements. The distinction between neglecta and oceania is rather exacting as mentioned already in detail when Sagitta lacunae was described from the lagoon water of the Palao Islands (ToкrokA, 1942). The absence of the collarette and the large eye-pigment in the present specimens seem to refer them to oceania rather than neglecta. However, it is noteworthy that these specimens have attained maturity at such a small body size.

(3) Sagitta regularis AIDA (Table 14): The armature formulae of the Shellback-specimens are closely related to those of the Eastropic Expedition specimens as given by Sund (1959b). This species seems to mature much more rapidly in the Shellback area than in the western part of the North Pacific, as indicated in individuals only $4 \mathrm{~mm}$ long having 5-8 mature oval eggs arranged in zigzag rows and in a $4.6 \mathrm{~mm}$ specimen in which the ovary reached to the ventral ganglion. The formulae of some small individuals resemble closely those of Sagitta bedfordii, but the apparent shape of the eye-pigment differs distinctly between regularis and bedfordii; it is roundish in the latter, while it is distinctly elongate in the former.

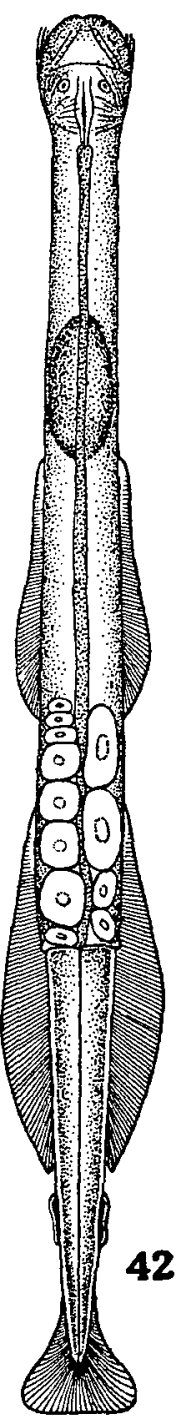

Fig. 15. Sagitta oceania GRAY. A $4.8 \mathrm{~mm}$ long individual from EQP S-28. 
14 Sogitta regularis

\begin{tabular}{|c|c|c|c|c|c|c|c|}
\hline No. & $\begin{array}{c}\text { body } \\
\text { lengih }\end{array}$ & $\begin{array}{l}\text { tail seg. } \\
\text { in } \%\end{array}$ & hook & $\begin{array}{c}\text { ont. } \\
\text { tee th }\end{array}$ & $\begin{array}{c}\text { posf. } \\
\text { teeth }\end{array}$ & maturity & loc. \\
\hline 1 & $3.3 \mathrm{~mm}$ & 37.3 & $10-10$ & $2-2$ & $2-3$ & im. & SB 35 \\
\hline 2 & 3.9 & 30.0 & $7-7$ & $2-2$ & $2-2$ & im. & SB 75 \\
\hline 3 & 4.0 & 35.5 & $8-9$ & $3-3$ & $4-4$ & m. & SB30 \\
\hline 4 & 4.0 & 32.8 & $8-8$ & $2-2$ & $3-3$ & m. & SB 30 \\
\hline 5 & 4.5 & 33.3 & $8-8$ & $3-3$ & $5-5$ & m. & SB 30 \\
\hline 6 & 4.6 & 34.3 & $6-7$ & $3-3$ & $4-4$ & m. & SB 80 \\
\hline 7 & 4.6 & 31.4 & $7-8$ & $3-?$ & $3-4$ & & SB40 \\
\hline 8 & 4.9 & 36.0 & $7-7$ & $2-3$ & $5-5$ & m. & SB 35 \\
\hline 9 & 4.9 & 33.3 & $7-7$ & $4-4$ & $4-4$ & & SB 35 \\
\hline 10 & 5.0 & 32.5 & $8-8$ & $4-4$ & $6-6$ & im. & SB 100 \\
\hline 11 & 5.1 & 34.2 & $7-8$ & $3-4$ & $6-6$ & m. & SB35 \\
\hline 12 & 5.1 & 33.3 & $8-8$ & $3-3$ & $4-4$ & m. & SB 30 \\
\hline 13 & 5.2 & 34.0 & $7-7$ & $3-4$ & $5-6$ & med. & SB 35 \\
\hline 14 & 5.2 & 33.8 & $6-6$ & $3-3$ & $5-5$ & med. & SB35 \\
\hline 15 & 5.2 & 33.8 & $8-8$ & $3-4$ & $4-5$ & & SB35 \\
\hline 16 & 5.2 & 33.8 & $7-7$ & $3-3$ & $3-3$ & med. & SB35 \\
\hline 17 & 6.9 & 32.0 & $8-8$ & $3-3$ & $4-5$ & m. & SB112 \\
\hline
\end{tabular}

Table 14. Armature formulae of $S$. regularis.

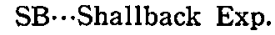

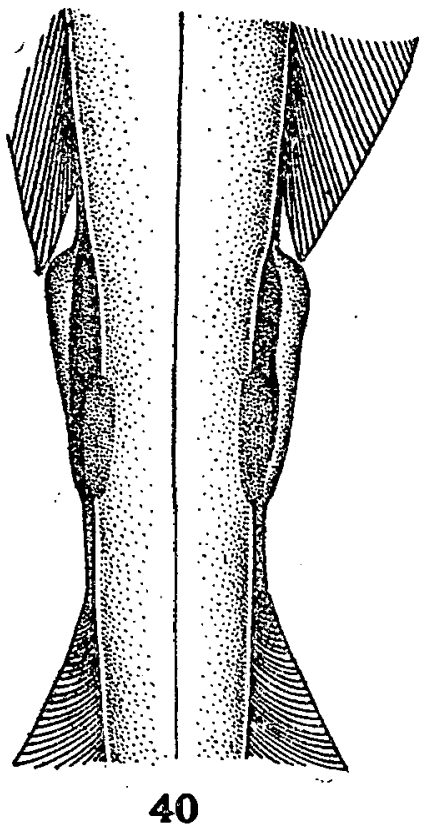

Fig. 16. Sagitta crassa f. naikaiensis ToKIoKA. A $6 \mathrm{~mm}$ long individual from the offshore waters of North Eastern Honsyû, Japan. Seminal vesicles. $\times 125$ 
15 Sagitta crasso f. naikaiensis

\begin{tabular}{|c|c|c|c|c|c|c|c|}
\hline No. & $\begin{array}{l}\text { body } \\
\text { length }\end{array}$ & $\begin{array}{l}\text { foil seg. } \\
\text { in } \%\end{array}$ & hook & $\begin{array}{l}\text { ant. } \\
\text { te e th }\end{array}$ & $\begin{array}{l}\text { post. } \\
\text { le eth }\end{array}$ & maturity & JAPAN \\
\hline 1 & & & & -2 & $2-3$ & im. & \multirow{6}{*}{ 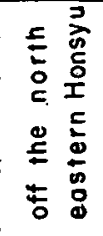 } \\
\hline 2 & 4.0 & 29.0 & $7-9$ & $4-4$ & $6-6$ & im. & \\
\hline 3 & 4.9 & 29.3 & $8-8$ & $4-4$ & $7-7$ & $\mathrm{im}$. & \\
\hline 4 & 5.4 & 7 & $8-9$ & $4-5$ & $7-8$ & $\mathrm{im}$. & \\
\hline 5 & t. & 8 & $7-8$ & $4-5$ & $8-8$ & med. & \\
\hline 6 & 6.0 & 30.4 & $9-9$ & $5-5$ & $9-9$ & $\mathrm{~m}$. & \\
\hline
\end{tabular}

Table 15. Armature formulae of $S$. crassa f. naikaiensis.

(4) Sagitta crassa f. naikaiensis TокіокA (Fig. 16, Table 15): To ascertain the identification of the specimens from the offshore waters off North-Eastern Honsyû, Japan, some individuals were dissected. The distinct collarette around the neck, the corona ciliata beginning at the level posterior to eyes, the large eye-pigment and the distinct but rather small intestinal diverticula together with the shape and situation of the seminal vesicles (Fig. 16) seem to ascertain the identity of these specimens with crassa f. naikaiensis. The ovary is limited to a range, posterior to the frontal end of the posterior fin.

\section{Sagitta neodecipiens $\mathbf{n}$. sp.}

(Figs. 17-20, Tables 16-17)

Length up to $13.2 \mathrm{~mm}$ in examined specimens. The tail segment occupies most frequently 28-29\% of the whole body length. General appearance of the body (Fig. 17) resembles closely that of $S$. decipiens. The anterior fin begins at the posterior end of the ventral ganglion. The posterior fin is nearly as long as or very slightly shorter than the anterior and divided approximately equally on the trunk and the caudal segment, although sometimes the anterior half along the trunk is slightly longer than the posterior half along the tail segment; it is widest near the trunktail septum. In both fins, the thin anterior terminal portion is devoid of fin rays; and in the posterior fin, there is a narrow rayless-zone along the trunk anterior to the female genital opening. The collarette is indiscernible in any of the examined specimens; no constriction at the trunk-tail septum. The eye-pigment (Fig. 18) is rather small, elongate and somewhat resembles that of $S$. bipunctata rather than that of $S$. decipiens. The pigment is not dense as in decipiens, but somewhat shorter than in decipiens. Length of pigment/length of eye $\times 100$ is 28.6 to 44.1 , being 40.2 on an average of seven measurements, and width of pigment/length of pigment $\times$ 100 is 31.8 to 50.0 and 39.2 on an average of seven measurements. In decipiens, length of pigment/length of eye $\times 100$ is 49.3 to 61.2 in three measurements and 55.7 on an average, and width of pigment/length of pigment $\times 100$ is 23.1 to 39.7 and 29.9 on an average. Thus, generally speaking, the pigment seems shorter, but 


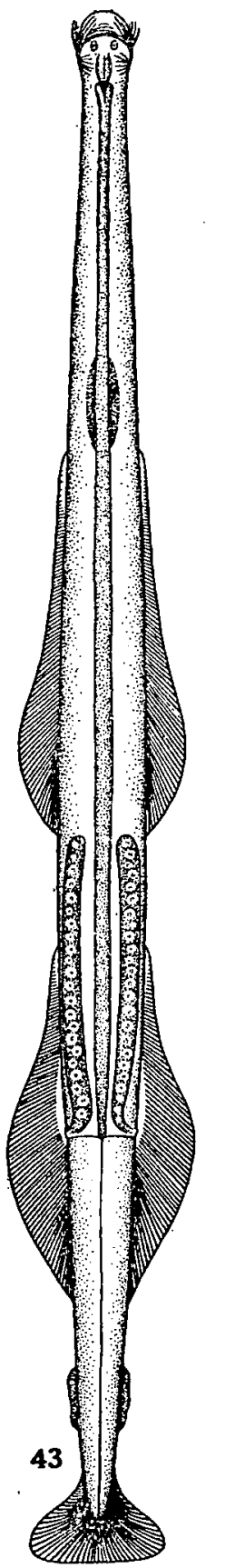

Fig. 17. Sagitta neodecipiens n. sp. A specimen from SB 1 , dorsal. relatively thicker than in decipiens. It is also shorter than that of S. serratodentata tasmanica. The armature formulae resembles closely those of decipiens as shown in Tables 16 and 17. Hooks are most frequently 6 , not serrated; the anterior teeth (Fig. 19) are very short and triangular as in decipiens and rows meet each other usually in right or obtuse angles. The ovary at maximum length reaches anteriorly to the posterior end of the anterior fin in examined specimens. The seminal vesicles (Fig. 20) are situated approximately at the middle of the distance between the posterior and caudal fins. They are elongate and provided with a glandular portion at the anterior end. The rupture occurs along the whole lateral side at maturity. The intestinal diverticula are present as in decipiens.

Remarks: The present species resembles so closely $S$. decipiens that it is hardly possible to separate distinctly immature specimens of these two forms not yet having any trace of the seminal vesicles. The only apparent distinction lies in the situation of these vesicles. The difference found in size of the eye-pigment is too exacting to be practicable as a clue to differentiating these forms. In decipiens, the vesicles are situated near the base of the caudal fin, being far apart from the posterior fin; distance between the posterior fin and the vesicle/distance between the vesicle and the caudal fin is 4.83 to 8.75 and 7.21 on an average of four measurements. While in the present form, the ratio is 0.29 to 2.08 and 1.12 on an average of 33 measurements. However, the original description of Sagitta decipiens was made by Fowler (1905) on specimens without seminal vesicles, consequently it is impossible to determine definitely whether the present form is identical with FowLER's original specimens or not. But in order to prevent confusion, it seems reasonable to recognize the forms described by RitTER-ZÁHONY (1911) as being identical with FOWLER's specimens. Then the present specimens are separable distinctly from decipiens described by 

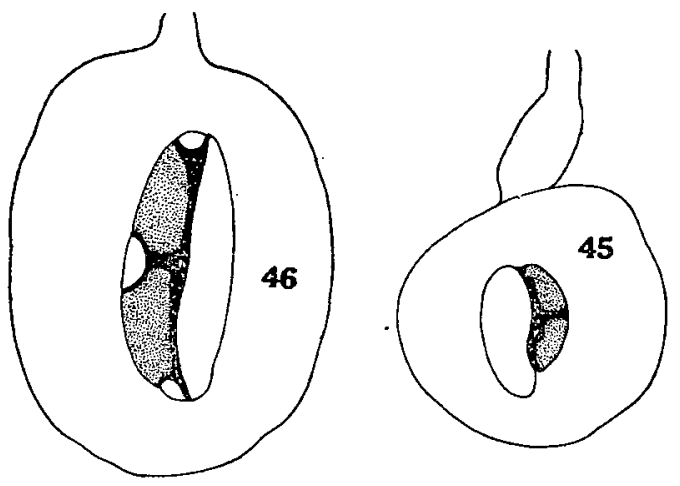

Fig. 18. Eyes of 45-Sagitta neodecipiens n. sp. from SB 181 and 46-Sagitta decipiens FOWLER from SB 181, magnified.

16

Sogitto neodecipiens

\begin{tabular}{|c|c|c|c|c|c|c|c|}
\hline No & $\begin{array}{l}\text { body } \\
\text { lèngth }\end{array}$ & $\begin{array}{l}\text { tail seg. } \\
\text { in } \%\end{array}$ & hook & $\begin{array}{l}\text { ant. } \\
\text { tee th }\end{array}$ & $\begin{array}{l}\text { post. } \\
\text { te e th }\end{array}$ & ty & loc. \\
\hline 1 & $7.3 \mathrm{~mm}$ & 31.0 & -6 & $8-8$ & $15-16$ & med. & SBII2 \\
\hline 2 & 7.4 & 29.8 & -6 & $7-7$ & $15-15$ & $\mathrm{im}$. & $B 112$ \\
\hline 3 & 7.8 & 31.7 & $6-6$ & $8-8$ & $17-17$ & med. & SB 112 \\
\hline 4 & 8.1 & 28.0 & $6-6$ & $7-7$ & $15-15$ & med. & 58112 \\
\hline 5 & 8.1 & 28.0 & $6-7$ & $6-6$ & $13-13$ & $\mathrm{im}$. & SB 122 \\
\hline 6 & 8.1 & 28.0 & $6-6$ & $7-8$ & $12-14$ & med. & SB 215 \\
\hline 7 & 8.5 & 30.7 & -7 & $7-7$ & $14-14$ & med. & SB 145 \\
\hline 8 & 8.7 & 28.4 & $6-6$ & $8-8$ & $14-14$ & med. & SB 122 \\
\hline 9 & 8.9 & 29.2 & $6-6$ & $8-8$ & $16-16$ & med. & SB 122 \\
\hline 10 & 9.0 & 29.7 & $6-6$ & $10-10$ & $17-18$ & $\mathrm{~m}$. & SB 181 \\
\hline 11 & & 30.0 & $6-6$ & $7-8$ & $14-14$ & $\mathrm{~m}$. & SB 150 \\
\hline 12 & 9.4 & 29.7 & -6 & $9-9$ & $19-19$ & $\mathrm{~m}$ & SB 122 \\
\hline 13 & 10.4 & 31.3 & $6-6$ & $9-10$ & $17-18$ & $\mathrm{im}$. & SB I \\
\hline 14 & 10.5 & 28.6 & $6-6$ & $8-9$ & $18-18$ & $\mathrm{im}$. & SB 50 \\
\hline 15 & 10.8 & 29.6 & $6-6$ & $9-10$ & $17-17$ & im. & SB 50 \\
\hline 16 & 10.9 & 28.6 & $6-6$ & $7-7$ & $13-14$ & im. & SB 1 \\
\hline 17 & 11.1 & 26.3 & $6-6$ & $8-9$ & $15-16$ & & SB I \\
\hline 18 & 11.1 & 29.4 & $6-6$ & $9-9$ & $16-17$ & im. & SB 50 \\
\hline 19 & 11.1 & 28.7 & $6-6$ & $8-8$ & $15-16$ & im. & SB 50 \\
\hline 20 & 11.2 & 29.1 & $6-6$ & $6-9$ & $17-17$ & $\mathrm{im}$. & SB 1 \\
\hline 21 & 11.2 & 27.7 & $6-6$ & $8-9$ & $16-18$ & med. & SB I \\
\hline 22 & 11.4 & 29.7 & $6-6$ & $9-10$ & $18-19$ & $\mathrm{im}$. & SB 50 \\
\hline 23 & 11.8 & 28.2 & $6-6$ & $9-9$ & $15-16$ & med. & SB I \\
\hline 24 & 12.1 & 27.4 & $6--6$ & $9-9$ & $16-17$ & $\mathrm{im}$. & $\mathrm{SBI}$ \\
\hline 25 & 12.7 & 28.2 & $6-6$ & $8-8$ & $15-16$ & med. & SB I \\
\hline 26 & 13.2 & 28.6 & $6-6$ & $9-9$ & $16-16$ & med. & SB I \\
\hline
\end{tabular}

Table 16. Armature formulae of $S$. neodecipiens.

SB...Shellback Exp.

$$
-87-
$$




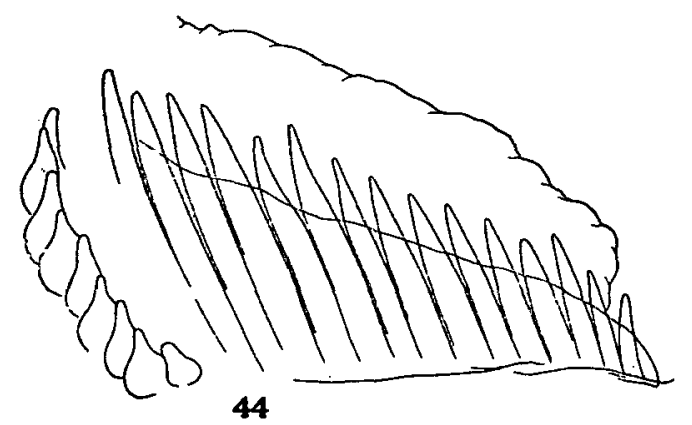

Fig. 19. Sagitta neodecipiens n. sp. Anterior and posterior teeth of an individual from $\mathrm{SB} 1$, magnified.

Sagitta decipiens

\begin{tabular}{|c|c|c|c|c|c|c|c|}
\hline No & $\begin{array}{l}\text { body } \\
\text { length }\end{array}$ & $\begin{array}{l}\text { toil seg. } \\
\text { in } \%\end{array}$ & hook & $\begin{array}{l}\text { ant } \\
\text { te e th }\end{array}$ & $\begin{array}{c}\text { post. } \\
\text { teeth }\end{array}$ & maturity & loc \\
\hline 1 & $3.6 \mathrm{~mm}$ & 32.7 & $7-7$ & $4-4$ & $6-6$ & $\mathrm{im}$. & EQPS 28 \\
\hline 2 & 5.5 & 29.4 & $7-7$ & $7-7$ & $11-13$ & $\mathrm{im}$. & EQPHI7 \\
\hline 3 & 6.2 & 25.0 & $7-7$ & $5-5$ & $10-10$ & $\mathrm{Im}$ & EQPH 17 \\
\hline 4 & 6.2 & 295 & $7-8$ & $6-6$ & $|1-1|$ & im. & EQPH 17 \\
\hline 5 & 7.5 & 28.7 & $6-7$ & $7-8$ & $13-14$ & $\mathrm{im}$ & $S B 122$ \\
\hline 6 & 8.8 & 27.4 & $6-7$ & $8-8$ & $14-14$ & $\mathrm{im}$. & SB122 \\
\hline 7 & 8.9 & 27.0 & $6-6$ & $8-8$ & $14-16$ & $\mathrm{~m}$. & SB90 \\
\hline 8 & 8.9 & 277 & $7-7$ & $9-9$ & $15-16$ & $m$ & SB 100 \\
\hline 9 & 9.0 & 28.1 & $6-6$ & $8-9$ & $17-18$ & $\mathrm{im}$. & SB 85 \\
\hline 10 & 9.1 & 25.0 & $6-6$ & $8-8$ & $14-15$ & $m$ & SB 180 \\
\hline 11 & 9.4 & 27.6 & $6-6$ & $9-9$ & $16-17$ & $\mathrm{im}$ & SB.50 \\
\hline 12 & 9.4 & \begin{tabular}{|l|}
276 \\
\end{tabular} & $5-6$ & $9-10$ & $17-18$ & & $S B 30$ \\
\hline 13 & 6 & 25.7 & $6-6$ & $8-8$ & $17-17$ & med. & $S 875$ \\
\hline 14 & 9.6 & 25.2 & $6-6$ & $9-9$ & $18-20$ & med. & SB 50 \\
\hline 15 & 9.6 & 27.2 & $6-6$ & $9-10$ & $18-19$ & $m$ & SB50 \\
\hline 16 & 10.1 & 27.1 & $6-6$ & $9-9$ & $17-18$ & $m$ & SB 85 \\
\hline 17 & 10.6 & 26.4 & $6-6$ & $9-10$ & $17-17$ & med. & SB 50 \\
\hline 18 & 10.7 & 27.4 & $5-6$ & $10-10$ & $20-20$ & & SB 30 \\
\hline 19 & 10.7 & 29.1 & $5-6$ & $9-9$ & $16-17$ & med. & SB I \\
\hline 20 & 10.7 & 27.4 & $6-6$ & $9-10$ & $18-19$ & $\mathrm{~m}$. & SB50 \\
\hline 21 & 10.7 & 26.8 & $6-6$ & $9-9$ & $19-20$ & med & SB 50 \\
\hline 22 & 10.7 & 27.3 & $6-6$ & $9-9$ & $15-17$ & med. & SB 85 \\
\hline 23 & 10.7 & 22.4 & $6-6$ & $8-8$ & $16-17$ & $\mathrm{~m}$. & SB 195 \\
\hline 24 & 11.2 & 25.0 & $6-6$ & $7-7$ & $14-15$ & $m$ & \begin{tabular}{|l|} 
SB \\
\end{tabular} \\
\hline 25 & 11.4 & 28.4 & $6-6$ & $7-8$ & $15-15$ & med. & SB I \\
\hline 26 & 13.2 & 24.6 & $6-7$ & $7-8$ & $19-19$ & med. & SB 181 \\
\hline 27 & & & $7-7$ & $7-7$ & $14-15$ & med. & EQPHII \\
\hline
\end{tabular}

Table 17. Armature formulae of $S$. decipiens.

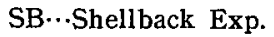




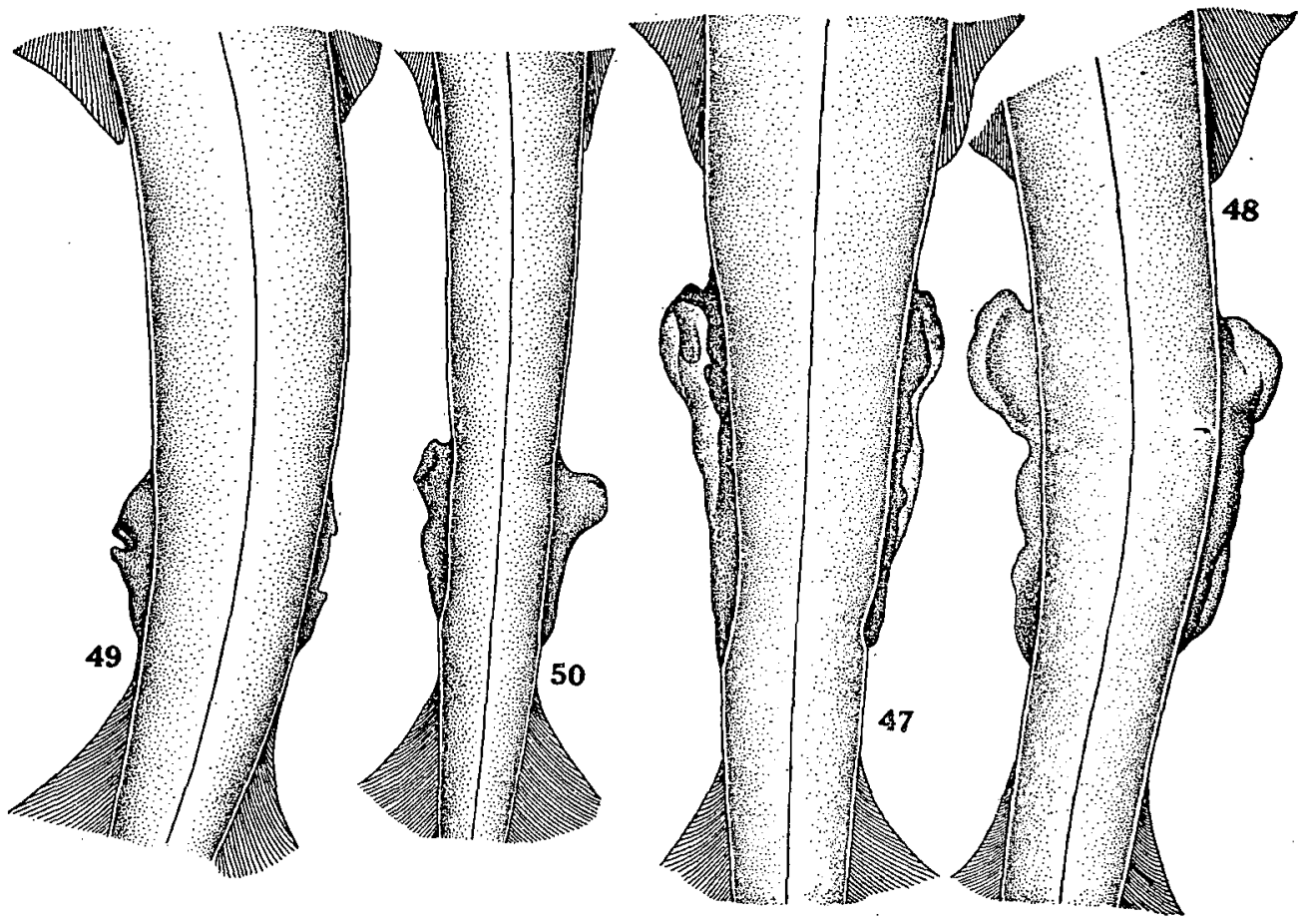

Fig. 20. Seminal vesicles of 47, 48-Sagitta neodecipiens $\mathrm{n}$. sp. from SB $50{ }_{a}^{\mathrm{fT}}$ respectively 11.1 and $10.8 \mathrm{~mm}$ in length, and 49,50-Sagitta decipiens FOWLER respectively from SB 181 and SB 195 (10.7 mm in length).

RITTER-ZAHONY by the situation of the seminal vesicles. So I think it best to treat the present form as a separate species differentiated from decipiens and named "neodecipiens" because of its close resemblance to decipiens.

\section{Sagitta bedoti BERANECK f. minor TOKIOKA}

(Table 18)

The specimens occurring in the Shellback area are all small, less than $13.3 \mathrm{~mm}$ in length and the ovary at its maximum length reaches to the posterior end of the anterior fin. The anterior end of the intestine may be slightly swollen and becomes whitish and opaque in some specimens. These features together with the armature formulae seem to assign the Shellback specimens to f. minor found abundantly in the tropical waters in the western Pacific. Specimens from the Eastropic Expedition resemble wholly the Shellback individuals (Sund, 1959b). The distance between eyes is comparatively large, distance between eyes/width of head is 34.3-40.0 in examined specimens. 
18

Sagitta bedofi f.minor

\begin{tabular}{|c|c|c|c|c|c|c|c|}
\hline No & $\begin{array}{c}\text { body } \\
\text { length }\end{array}$ & $\begin{array}{c}\text { tail seg. } \\
\text { in } \%\end{array}$ & hook & $\begin{array}{c}\text { ant. } \\
\text { te e th }\end{array}$ & $\begin{array}{c}\text { post. } \\
\text { te eth }\end{array}$ & molurity & loc. \\
\hline 1 & $5.9 \mathrm{~mm}$ & 22.2 & $6-7$ & $6-?$ & $20-20$ & im. & SB 75 \\
\hline 2 & 6.1 & 25.5 & $7-7$ & $8-8$ & $17-18$ & im. & SB 60 \\
\hline 3 & 7.2 & 27.3 & $7-7$ & $6-7$ & $20-20$ & im. & SB 95 \\
\hline 4 & 7.3 & 26.5 & $6-7$ & $9-9$ & $23-23$ & im. & SB 60 \\
\hline 5 & 7.8 & 25.0 & $7-7$ & $10-10$ & $20-21$ & im. & SB 55 \\
\hline 6 & 7.9 & 25.4 & $8-8$ & $10-10$ & $25-27$ & im. & SB 55 \\
\hline 7 & 7.9 & 24.6 & $7-7$ & $10-10$ & $24-25$ & im. & SB 64 \\
\hline 8 & 8.2 & 25.4 & $7-7$ & $7-8$ & $20-20$ & im. & SB 100 \\
\hline 9 & 8.4 & 24.8 & $7-7$ & $10-10$ & $24-24$ & im. & SB 75 \\
\hline 10 & 8.6 & 24.8 & $6-7$ & $9-11$ & $29-30$ & im. & SB 60 \\
\hline 11 & 8.7 & 28.4 & $7-7$ & $9-9$ & $23-24$ & med. & SB 90 \\
\hline 12 & 9.1 & 28.6 & $7-7$ & $9-9$ & $24-24$ & med. & SB 105 \\
\hline 13 & 9.2 & 26.1 & $6-7$ & $10-10$ & $29-30$ & med. & SB 55 \\
\hline 14 & 9.2 & 25.4 & $6-6$ & $11-11$ & $28-30$ & im. & SB 60 \\
\hline 15 & 9.3 & 26.5 & $7-7$ & $10-11$ & $25-26$ & im. & SB 55 \\
\hline 16 & 9.5 & 24.7 & $7-7$ & $9-10$ & $22-22$ & med. & SB 80 \\
\hline 17 & 9.8 & 26.0 & $7-7$ & $11-11$ & $22-24$ & med. & SB 80 \\
\hline 18 & 9.8 & 22.7 & $8-8$ & $9-10$ & $25-26$ & im. & SB 155 \\
\hline 19 & 10.1 & 23.2 & $7-7$ & $12-12$ & $26-26$ & med. & SB64 \\
\hline 20 & 10.3 & 24.8 & $7-7.12-12$ & $26-27$ & & SB 166 \\
\hline 21 & 10.4 & 24.7 & $7-7$ & $10-10$ & $27-27$ & & SB 166 \\
\hline 22 & 10.4 & 23.8 & $8-8$ & $10-10$ & $22-22$ & med. & SB 105 \\
\hline 23 & 10.6 & 24.5 & $7-7$ & $10-10$ & $24-25$ & med. & SB 68 \\
\hline 24 & 10.9 & 25.0 & $7-7$ & $8-9$ & $24-24$ & med. & SB 155 \\
\hline 25 & 10.9 & 24.0 & $6-8$ & $12-12$ & $29-30$ & im. & SB 71 \\
\hline 26 & 11.1 & 23.5 & $7-7$ & $10-10$ & $25-26$ & im. & SB 68 \\
\hline 27 & 12.0 & 24.3 & $7-8$ & $11-11$ & $24-27$ & med. & SB68 \\
\hline 28 & 12.0 & 23.9 & $7-7$ & $11-11$ & $29-29$ & med. & SB 68 \\
\hline 29 & 12.1 & 23.7 & $7-7$ & $11-11$ & $29-29$ & im. & SB 155 \\
\hline 30 & 13.3 & 24.4 & $7-7$ & $10-10$ & $26-28$ & m. & SB 109 \\
\hline 31 & 13.3 & 26.3 & $7-7$ & $10-11$ & $26-26$ & m. & SB 109 \\
\hline & & & & & & \\
\hline
\end{tabular}

Table 18. Armature formulae of $S$. bedoti. SB...Shellback Exp.

\section{Sagitta hexaptera D'ORBIGNY}

(Fig. 21)

Many large specimens, $40-50 \mathrm{~mm}$ in length, were collected from the Shellback area, the largest of all was the $58 \mathrm{~mm}$ long individual from SB 195 . These seem to be slightly larger than the Eastropic specimens (SUND, 1959b). As there are some specimens in which the seminal vesicles are quite mature and preserved perfectly, a typical one is shown here in Fig. 21. The situation of the vesicle varies considerably, 


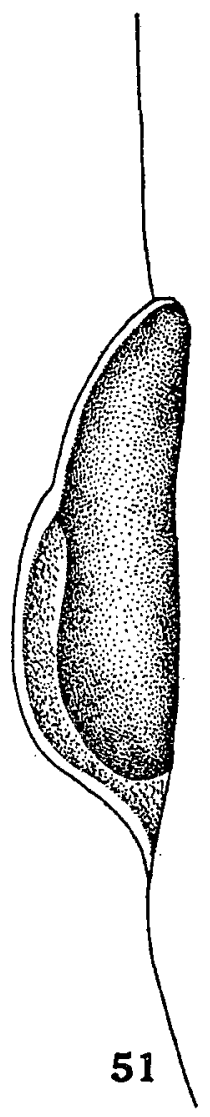

Fig. 21. Sagitta hexaptera D'ORBIGNY. Seminal vesicle of an individual from MP $16 . \times 125$.

although it is nearer the caudal fin than the posterior fin; distance between posterior fin and vesicle/distance between vesicle and caudal fin is 4.33 to 6.64 , being 5.25 on an average of 5 measurements. The shape is elongate and slightly swollen in the posterior half, where the glandular tissue is found.

\section{Sagitta enflata f. gardineri DONCASTER}

(Table 19)

Sagitta gardineri...DONCASTER (1903): Chaetognatha, with a note on the variation and distribution of the group. The fauna and geography of the Maldive and Laccadive Archipelagoes, Vol. I.

Sagitta inflata, gardineri-Typus...RITTER-ZÁHONY (1909): Denkschriften der MathematischNaturwissenschaftlichen Klasse der Kaiserlichen Akademie der Wissenschaften Wien, Bd. LXXXIV, pp. 5-7. 
There were found many large individuals of $S$. enflata in the Shellback area, especially at Stations SB 112 and SB 122 . They attain $27 \mathrm{~mm}$ in body length; the ovary is long, generally reaching to the middle of the anterior fin at maturity and contains up to one hundred or more eggs in one organ; it may reach even to the frontal end of the anterior fin (No. 5 in the Table). Contrarily, the ordinary small forms (minor-Typus by RITTER-ZÁHONY) have much shorter ovaries that are limited within the area posterior to the frontal end of the posterior fin and containing up to 30 eggs. FAGETTI (1958a) also found such larger individuals with longer ovaries in the waters off Central-Northern Chile. She notes that the larger specimens are provided with more teeth than the smaller ones and this is true also in the Shellback individuals. However, it is rather a general feature that the teeth increase with body length. The armature formulae of both forms from the Shellback area seem to be continuous as shown in the table. Ten anterior teeth are recorded also on

19

\begin{tabular}{|c|c|c|c|c|c|c|c|}
\hline No & $\begin{array}{l}\text { body } \\
\text { length }\end{array}$ & $\begin{array}{l}\text { tailseg. } \\
\text { in } \%\end{array}$ & hook & $\begin{array}{l}\text { ant. } \\
\text { te eth }\end{array}$ & $\begin{array}{l}\text { post. } \\
\text { teeth }\end{array}$ & moturity & loc. \\
\hline \multicolumn{8}{|c|}{ Sagitio enflato ordinary form } \\
\hline 1 & $12.7 \mathrm{~mm}$ & 19.0 & $9-10$ & $7-8$ & $12-13$ & m. & \multirow{4}{*}{$\begin{array}{l}\stackrel{N}{\bar{m}} \\
\text { 足 }\end{array}$} \\
\hline 2 & 13.2 & 19.0 & $9-9$ & $7-8$ & $11-12$ & m. & \\
\hline 3 & 13.7 & 19.0 & $10-10$ & $7-8$ & $12-13$ & m. & \\
\hline 4 & 17.2 & 17.0 & $10-10$ & $8-8$ & $14-15$ & $\mathrm{~m}$. & \\
\hline \multicolumn{8}{|c|}{ Sagisia enflato large form } \\
\hline 5 & 25.4 & 18.0 & $10-10$ & $10-11$ & $16-16$ & $\mathrm{~m}$. & \multirow{6}{*}{ 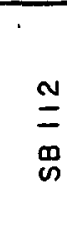 } \\
\hline 6 & 25.7 & 18.0 & $10-10$ & $9-9$ & $16-17$ & m. & \\
\hline 7 & 26.0 & 18.0 & $9-9$ & $9-9$ & $7+*-15$ & $\mathrm{~m}$. & \\
\hline 8 & 26.5 & 18.0 & $9--10$ & $10-10$ & $14-15$ & $\mathrm{~m}$. & \\
\hline 9 & 27.0 & 18.0 & $10--10$ & $10-11$ & $15-16$ & $\mathrm{~m}$. & \\
\hline 10 & 27.0 & 17.0 & $9-10$ & $9-9$ & $15-15$ & m. & \\
\hline
\end{tabular}

Table 19. Armature formulae of S. enflata.

* Some torn out. SB...Shellback Exp.

$\therefore$ me larger individuals of the small form as indicated by Sund (1959b) on a 11.8 $\mathrm{mm}$ long specimen from the Eastropic Expedition and on 15.4-15.6 mm long specimens which were collected by HIDA in the middle part of the North Pacific. For these reasons, I hesitate to consider the number of teeth as a significant characteristic. At any rate, these large forms with longer ovaries can be safely identified as Sagitta enflata f. gardineri, first described by DONCASTER (1903) from the waters around the Maldive and Laccadive Islands and later reported by RITTER-ZÁHONY (1909) from the Red Sea. It is not yet known from the Mediterranean Sea (GHIRARDELli 1951, Massuti 1958). As it is hardly possible to distinguish young individuals of this form from those of the ordinary type, the exact range of distribution is not yet fully known. If the occurrence of this form is confined to some special water masses or if it is ascertained that there is no intermediate state between the longer and 
shorter ovaries at maturity, then gardineri should be treated as a variety or even a distinct species.

\section{Sagitta lyra $\mathrm{K}_{\mathrm{ROHN}}$}

(Fig. 22)

The fully matured seminal vesicles of this species resemble closely that of enflata, nearly spherical in shape and rupture around the apex. The vesicles are situated near the rear end of the posterior fin, being widely separated from the caudal fin.

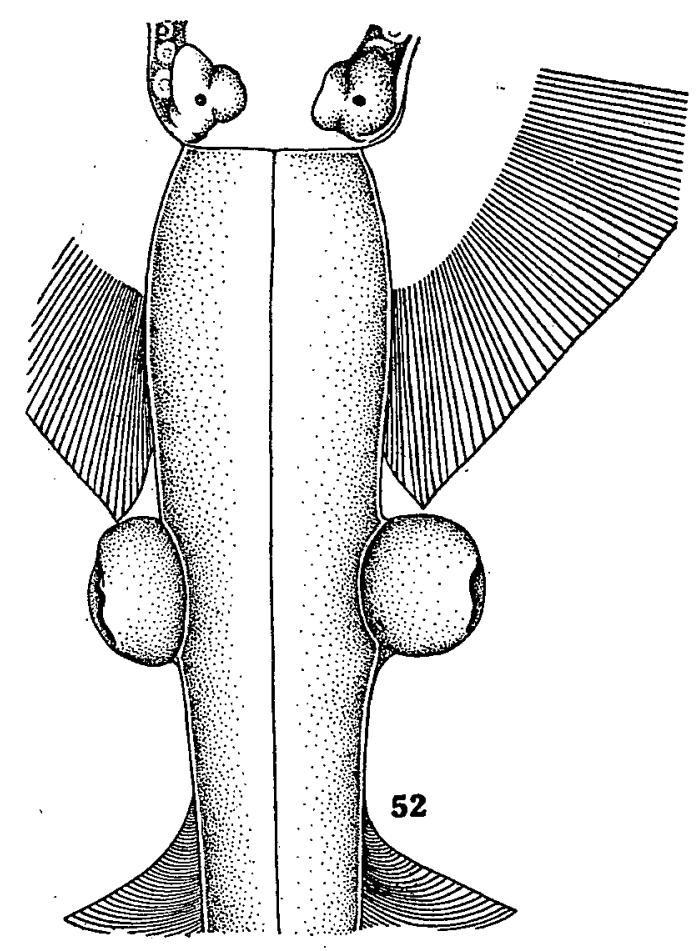

Fig. 22. Sagitta lyra KROHN. Seminal vesicles of a $32.5 \mathrm{~mm}$ long individual from SB 1, dorsal.

\section{Other species of Sagitta}

(Tables 20-22)

A few specimens of some other species were dissected to ascertain identification. Their armature formulae are given in small tables 20-22. Young individuals of Sagitta pulchra are sometimes provided with 7 hooks. Some specimens of Sagitta minima from the Shellback area seem to bear more teeth than the Eastropic speci- 
mens (Sund, 1959b). The formulae of planctonis seem to fall in the range of variations generally admitted for this species.

20
\begin{tabular}{|c|c|c|c|c|c|c|c|}
\hline \multicolumn{1}{|c|}{ Sagitia puichra } \\
\hline 1 & 7.2 & 22.7 & $7-7$ & $6-6$ & $10-10$ & $\mathrm{im}$. & MP 14 \\
\hline 2 & 15.7 & 20.7 & $5-6$ & $6-6$ & $13-13$ & m. & TP \\
\hline 3 & & & $6-6$ & $8-8$ & $12-13$ & m. & EQPHII \\
\hline
\end{tabular}

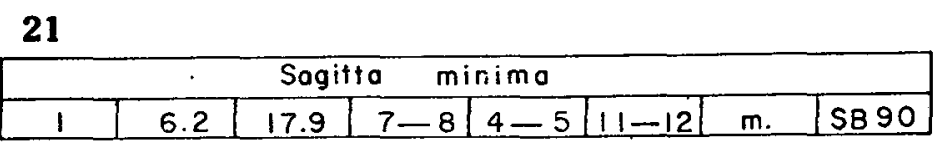

22

Sagitta planctonis

\begin{tabular}{|c|c|c|c|c|c|c|c|}
\hline No & $\begin{array}{c}\text { body } \\
\text { length }\end{array}$ & $\begin{array}{c}\text { tail seg. } \\
\text { in } \%\end{array}$ & nook & $\begin{array}{c}\text { ont. } \\
\text { tee th }\end{array}$ & $\begin{array}{c}\text { post. } \\
\text { te eth }\end{array}$ & maturity & loc. \\
\hline 1 & $6.4 \mathrm{~mm}$ & 27.6 & $10-10$ & $3-5$ & $7-8$ & $\mathrm{im}$. & SB 30 \\
\hline 2 & 10.3 & 25.3 & $9-9$ & $5-5$ & $9-9$ & im. & SB 170 \\
\hline 3 & 19.8 & 26.2 & $9-9$ & 8 & 14 & & SB I \\
\hline 4 & 20.8 & 25.0 & $9-9$ & 8 & 13 & & SB 1 \\
\hline
\end{tabular}

Tables 20-22. Armature formulae of S. pulchra (20), minima (21) and

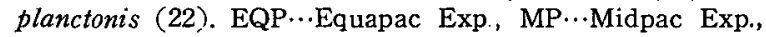

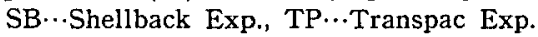

\section{Krohnitta subtilis (GRASSI) and K. pacifica (AIDA)}

(Fig. 23, Tables 23-24)

The mature seminal vesicles of $K$. subtilis are very elongate and touch both the posterior and the caudal fins; the rupture occurs at first at the antero-lateral corner of the vesicle (Fig. 23), but afterwards it extends to nearly the whole lateral

23

\begin{tabular}{|c|c|c|c|c|c|c|}
\hline \multicolumn{7}{|c|}{ Krohnitta Pacifica } \\
\hline 1 & 5.9 & 33.3 & $9-9$ & $15-15$ & i m. & SB 35 \\
\hline 2 & 6.2 & 32.3 & $8-8$ & $13-13$ & m & SB170 \\
\hline 3 & 6.9 & 29.2 & $8-8$ & $13-14$ & m. & SB 35 \\
\hline 4 & 7.3 & 28.6 & $9-10$ & $14-14$ & m. & SB 35 \\
\hline 5 & 8.0 & 30.9 & $8-8$ & $15-15$ & $\mathrm{~m}$ & SB 35 \\
\hline 6 & 8.0 & 33.3 & $9-10$ & $15-15$ & m. & SB115 \\
\hline 7 & 8.3 & 29.7 & $8-9$ & $14-15$ & m & SB118 \\
\hline
\end{tabular}

24

\begin{tabular}{|c|c|c|c|c|c|c|}
\hline \multicolumn{1}{|c|}{ Krohnitto } & subtilis \\
\hline 1 & 11.4 & 31.4 & $8-8$ & $10-11$ & $\mathrm{~m}$. & SB170 \\
\hline 2 & 12.0 & 32.4 & $7-7$ & $11-12$ & $\mathrm{~m}$ & SB170 \\
\hline
\end{tabular}

Tables 23-24. Armature formulae of $K$. pacifica (23) and subtilis (24). SB $\cdots$ Shellback Exp. 


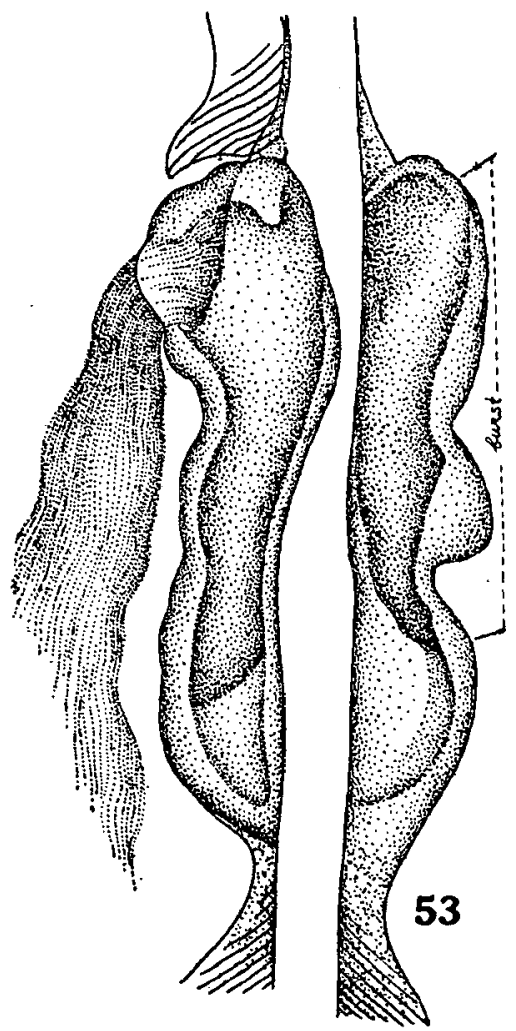

Fig. 23. Krohnitta subtilis (GRASSI). Seminal vesicles of an individual from SB $44 . \times 125$.

side leaving only a small posterior part of the vesicle intact. The Shellback specimens of $K$. pacifica seem to be provided with slightly more hooks than the Eastropic specimens (SUND, 1959b).

\section{Distribution and Faunistic Notes}

\section{LAGOONS OF BAJA CALIFORNIA}

(Fig. 24, Tables 25-26)

1) Scammons lagoon. This lagoon is situated approximately at $27^{\circ} 45^{\prime} \mathrm{N} \times 114^{\circ}$ $10^{\prime} \mathrm{W}$ (Fig. 24) and the shallow bottom is covered by eel grass. Ten plankton samples were taken with a small net at nine of the 17 stations in the lagoon. Only S. tenuis was found in six of the samples. Generally speaking, plankton samples from the outer stations (Sts. 10,15 and 16) were characterized by a dominance of the copepod, Paracalanus, those from the middle part (Sts. 11 and 17) were densely populated by Oithona and the samples from the inner portion (Sts. 12-14) were 


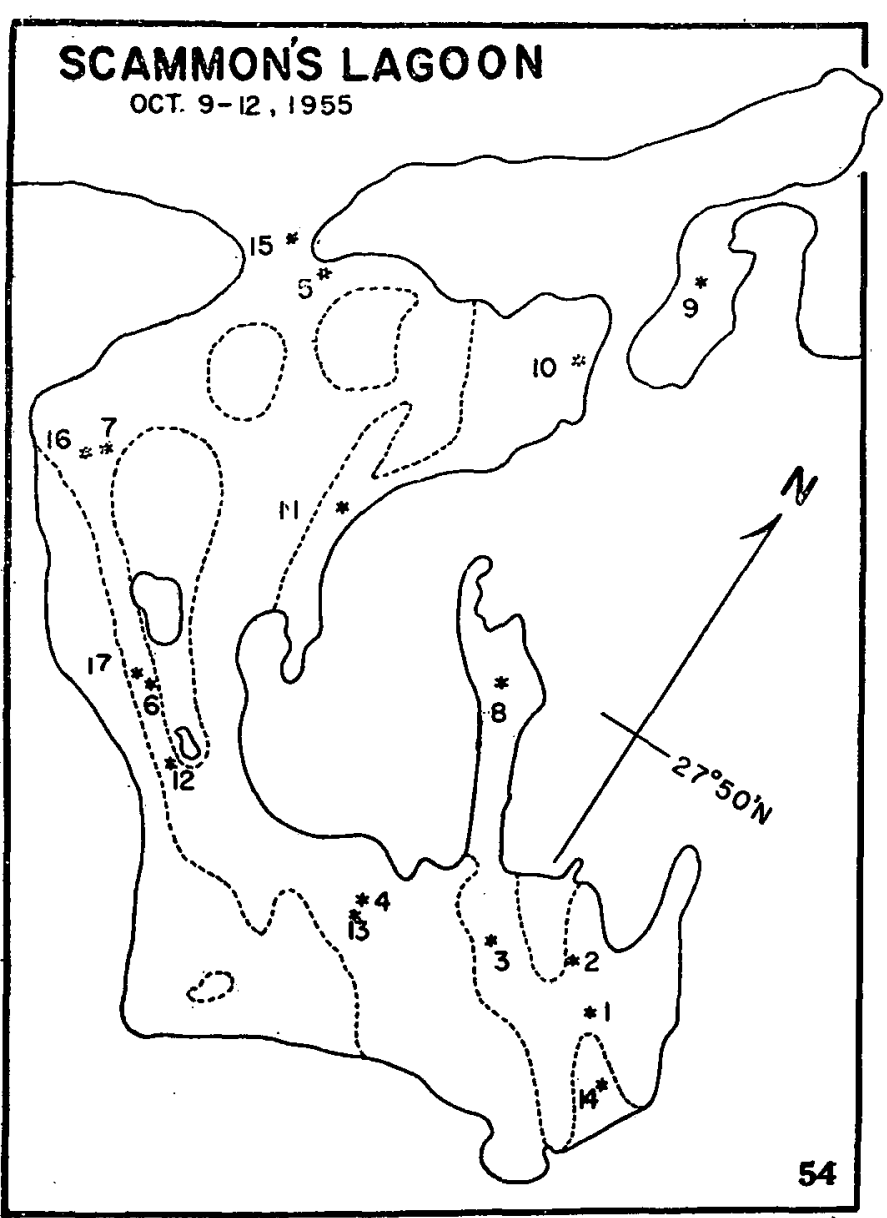

Fig. 24. Map of Scammons Lagoon, showing the sampling stations.

\begin{tabular}{|c|c|c|c|c|c|c|c|}
\hline Stations & 10 & 11 & $15 \mathrm{~A}$ & $15 \mathrm{~B}$ & 16 & 17 & total \\
\hline$<3 \mathrm{~mm}$ & 1 & 3 & 23 & 12 & 12 & 2 & 53 \\
\hline $3.1-5 \mathrm{~mm}$ & 3 & 7 & 14 & 20 & 13 & 15 & 72 \\
\hline $5.1-7 \mathrm{~mm}$ & 1 & - & 1 & 13 & 3 & 21 & 39 \\
\hline $7.1-9 \mathrm{~mm}$ & - & - & 4 & 2 & 2 & 10 & 18 \\
\hline $9.1-10.7 \mathrm{~mm}$ & - & - & - & - & - & 1 & 1 \\
\hline total & 5 & 10 & 42 & 47 & 30 & 49 & 183 \\
\hline Salinity (\%o) & 36.3 & 36.7 & & 34.7 & 37.6 & 38.8 & \\
\hline
\end{tabular}

Table 25. Occurrence of Sag. tenuis in Scammons lagoon. 


\begin{tabular}{|c|c|c|c|}
\hline Stations & 1 & 2 & total \\
\hline Body length & 1 & 4 & 5 \\
\hline $3.1-5 \mathrm{~mm}$ & - & 2 & 2 \\
\hline $5.1-7 \mathrm{~mm}$ & 1 & 6 & 7 \\
\hline total & 1 & 4 \\
\hline
\end{tabular}

Table 26. Occurrence of Sag. tenuis in Manuela lagoon.

crowded with Acartia. However, on some tidal phase these copepods may occur mingled with one another or Acartia may be very abundant at the outer-most station (St. 15) where the water flows in or out very violently. The distribution of $S$. tenuis seemed to be confined to the Paracalanus-Oithona area at the time when the collections were made; none was found in the inner portion (Sts. 1-4, 6, 8, 12-14) where the salinity reached $39.5-47.9 \%$. The highest salinity recorded at stations where this chaetognath was found was $38.8 \%$ (St. 17) and the maximum body length measured on the collected specimens at these stations was $10.7 \mathrm{~mm}$.

2) Manuela lagoon. A few specimens of S.tenuis were found in two plankton samples collected with a small net. Very probably S. tenuis is the only chaetognath, which can live in such lagoons situated along the coast of Lower California and characterized by comparatively high salinity.

\section{THE INLET WATERS ALONG THE PACIFIC COAST OF JAPAN}

A single haul with a small net, $17 \mathrm{~cm}$ in the mouth diameter, was made from $0-17 \mathrm{~m}$ in the morning of Oct. 7 during the Transpac Expedition near the entrance to Yokosuka Harbour in Tôkyô Bay. Eighty chaetognaths were found in this sample, all belonging to $S$. crassa f. naikaiensis which is known as a plankton indicator of the inlet waters, being found very abundantly and commonly in embayments along the coast of Japanese Islands.

\section{ELEGANS-WATER IN THE NORTH PACIFIC}

(Appendix table 2)

Of the samples of the Transpac Expedition 1953; thirty-nine (Nos. TP 19-50,53, 61, 63-66 and 73) contain only cold water species, Sagitta elegans and Eukrohnia hamata, or only the former. E. hamata was found only at two stations (TP 20 and 21) and only a single individual in each case.

\section{MIXING AREA OF THE ELEGANS-WATER AND THE WARM WATER}

\section{(Appendix table 3)}

With regards to samples from the surface water above $50 \mathrm{~m}$, Sagitta minima 
seems to be the commonest of five warm water species occurring throughout the whole mixing area. In the eastern part of the Pacific, S. lyra occurs rather regularly in. the mixing area, while in the western half $S$. enflata joins the fauna and in more western part than $150^{\circ} \mathrm{E}, S$. bedoti and $S$. crassa f. naikaiensis are added to the population. The occurrence of S. lyra has been reported by LEA (1955) along the west coast of the Queen Charlotte Islands, British Columbia, by Sund (1959) in the Gulf of Alaska, by Tchindonova (1955) in the southern part of the Bering Sea, and by HIDA (1957) in the Transition Zone north of the Hawaiian Islands. The last author stated Pterosagitta draco, S. hexaptera, S. serratodentata and S. bipunctata decrease markedly in the transition zone, but on the contrary S. lyra increases there. MARUMO and others (1958) also mention that besides S. elegans, S. bedoti, S. minima and E. hamata, S. lyra occurred in the upper $80 \mathrm{~m}$ layer at $40^{\circ} \mathrm{N}, 150^{\circ} \mathrm{E}$ (p. 183). The higher concentration of S. minima near the northern boundary of the warm water mass in the North Pacific is clearly illustrated by BIERI (1959). The occurrence of $S$. bedoti and $S$. crassa $\mathrm{f}$. naikaiensis in the western mixing area is evidently a natural result of the distribution of bedoti-water as is shown later in the section on bedoti-water, and of course this phenomenon is also observable in the Japan Sea.

\section{THE BLUE-GREEN WATER ALONG SOUTHERN CALIFORNIA}

(Table 27)

Nineteen plankton samples were collected March 12-13, 1956 in the coastal blue-green water along the Californian coast from San Diego to Long Beach. A small net, $17 \mathrm{~cm}$ in the mouth diameter, was towed from $20-40 \mathrm{~m}$ to the surface. Chaetognaths, represented by a single species $S$. friderici, were found in sixteen of these samples. Since small, yound individuals were distributed widely in the surveyed area as shown in Table 27, it appears that this species propagates within this blue-green water. Of the 35 plankton samples collected off San Diego with a similar small net and stored at Scripps Institution, 27 contained S. friderici and some unidentifiable

\begin{tabular}{|c|c|c|}
\hline 27 & Number of individual & Frequency of Occurrence \\
\hline $1-4 \mathrm{~mm}$ & 92 & $16 / 16$ \\
\hline $5-8 \mathrm{~mm}$ & 23 & $3 / 16$ \\
\hline $9-12 \mathrm{~mm}$ & 3 & $1 / 16$ \\
\hline $13-16 \mathrm{~mm}$ & 5 & $2 / 16$ \\
\hline $17-19 \mathrm{~mm}$ & 4 & $2 / 16$ \\
\hline total & 127 & \\
\hline
\end{tabular}

Table 27. Occurrence of Sag. friderici in the blue-green water along Souther California March 12-13, 1956. 
juveniles or damaged specimens. Some cold water plankton animals, such as Oiko. pleura labradoriensis and Fritillaria borealis f. typica, were found rather commonly in this water, together with a neritic species such as Oikopleura dioica. Therefore. the blue-green water is apparently a mixture of northern cold subarctic water and coastal water, although no individual of $S$. elegans has ever been reported from the area. The details of the occurrence of $S$. friderici off California have been described by Michael (1911), under the name S. bipunctata, and also refered by BiERI (1959).

\section{BEDOTI-AREA}

I. Occurrence of $\mathbf{S}$. bedoti in the eastern Pacific (Fig. 25, Table 28)

The occurrence of $S$. bedoti in the eastern Pacific was first reported by BIERI (1957) from the waters off Peru. Later, the distribution of this species in the Shellback area was clearly illustrated in his second paper (1959). More recently the

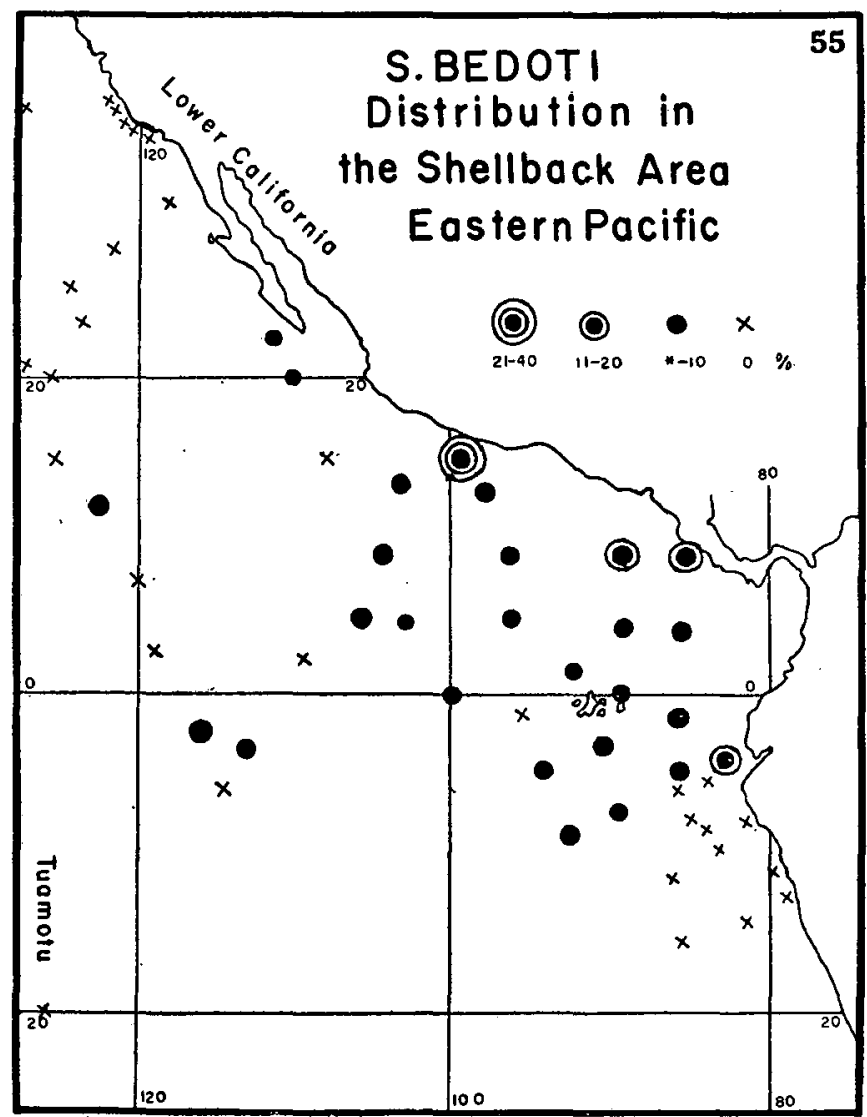

Fig. 25. Distribution of Sagitta bedoti in the Shellback area. 


\begin{tabular}{|c|c|c|c|c|c|c|c|}
\hline Stations & $\begin{array}{c}\text { Number } \\
\text { of ind. }\end{array}$ & $\%$ & $\begin{array}{c}\text { bed. } \\
\text { enf. }\end{array}$ & Stations & $\begin{array}{c}\text { Number } \\
\text { of ind. }\end{array}$ & $\%$ & $\begin{array}{c}\text { bed. } \\
\text { enf. }\end{array}$ \\
\hline SB 20 & 1 & $*$ & $*$ & SB 109 & 101 & 12 & 0.54 \\
\hline SB 35 & 5 & $*$ & 0.02 & SB 155 & 30 & 2 & 0.06 \\
\hline SB 44 & 6 & $*$ & 0.02 & SB 160 & 11 & 1 & 0.03 \\
\hline SB 55 & 20 & 1 & 0.05 & SB 166 & 215 & 19 & 0.52 \\
\hline SB 60 & 38 & 4 & 0.19 & SB 170 & 299 & 15 & 0.33 \\
\hline SB 64 & 4 & 1 & 0.04 & SB 175 & 27 & 2 & 0.08 \\
\hline SB 68 & 137 & 22 & 0.77 & SB 180 & 41 & 2 & 0.11 \\
\hline SB 71 & 1 & $*$ & 0.02 & SB 181 & 7 & 1 & 0.02 \\
\hline SB 75 & 12 & 3 & 0.17 & SB 187 & 131 & 7 & 0.16 \\
\hline SB 80 & 32 & 2 & 0.06 & SB 195 & 12 & 3 & 0.14 \\
\hline SB 90 & 1 & $*$ & $*$ & SB 200 & 105 & 5 & 0.09 \\
\hline SB 95 & 1 & $*$ & $*$ & SB 215 & 1 & $*$ & $*$ \\
\hline SB 100 & 15 & 1 & 0.02 & SB 217 & 2 & $*$ & $*$ \\
\hline SB 105 & 7 & $*$ & 0.01 & $*<1 \%$ or 0.01 & & \\
\hline
\end{tabular}

Table 28. Occurrence of $S$. bedoti in the Shellback area.

presence of the species was reported by Sund (1959b and c) also in the area of the Eastropic Expedition. The species seems to be absent off northern-central Chile (FAGETTI; 1958a). Three additional papers dealing with the chaetognaths of the coastal waters of North America have appeared; namely MichAel (1911), LEA (1955) and Sund (1959a). In all of these reports $S$. bedoti was quite absent. I found this species in 27 of the 48 Shellback samples examined (Frequency of Occurrence 56\%), of which the northernmost station was SB 217, the southernmost station SB 95 and the western-most station was SB 20. It was most abundant at stations along the coast between $15^{\circ} \mathrm{N}$ and $5^{\circ} \mathrm{S}$, but decreases rather sharply in the offshore water. This species occurs in the Shellback area in rather large numbers at some stations, but yet the proportion of the species to the total chaetognaths is not high; it was $22 \%$ at SB 68 , but most frequently it is less than $5 \%$. The proportion of $S$. bedoti to $S$, enflata (bedoti/enflata) is especially low, never reaching 0.8 and mostly less than 0.5 .

II. Occurrence of $\mathbf{S}$. bedoti at the western stations near Japan (Fig. 26, Tables 29-32).

The Occurrence of this species in the waters around Japan has been reported repeatedly (AIDA 1897, as S. bipunctata; ToKIOKA 1939, 1940, 1951, 1954 and 1957; Furuhashi 1953, Bieri 1959). Besides, there are several data reporting the occur- 


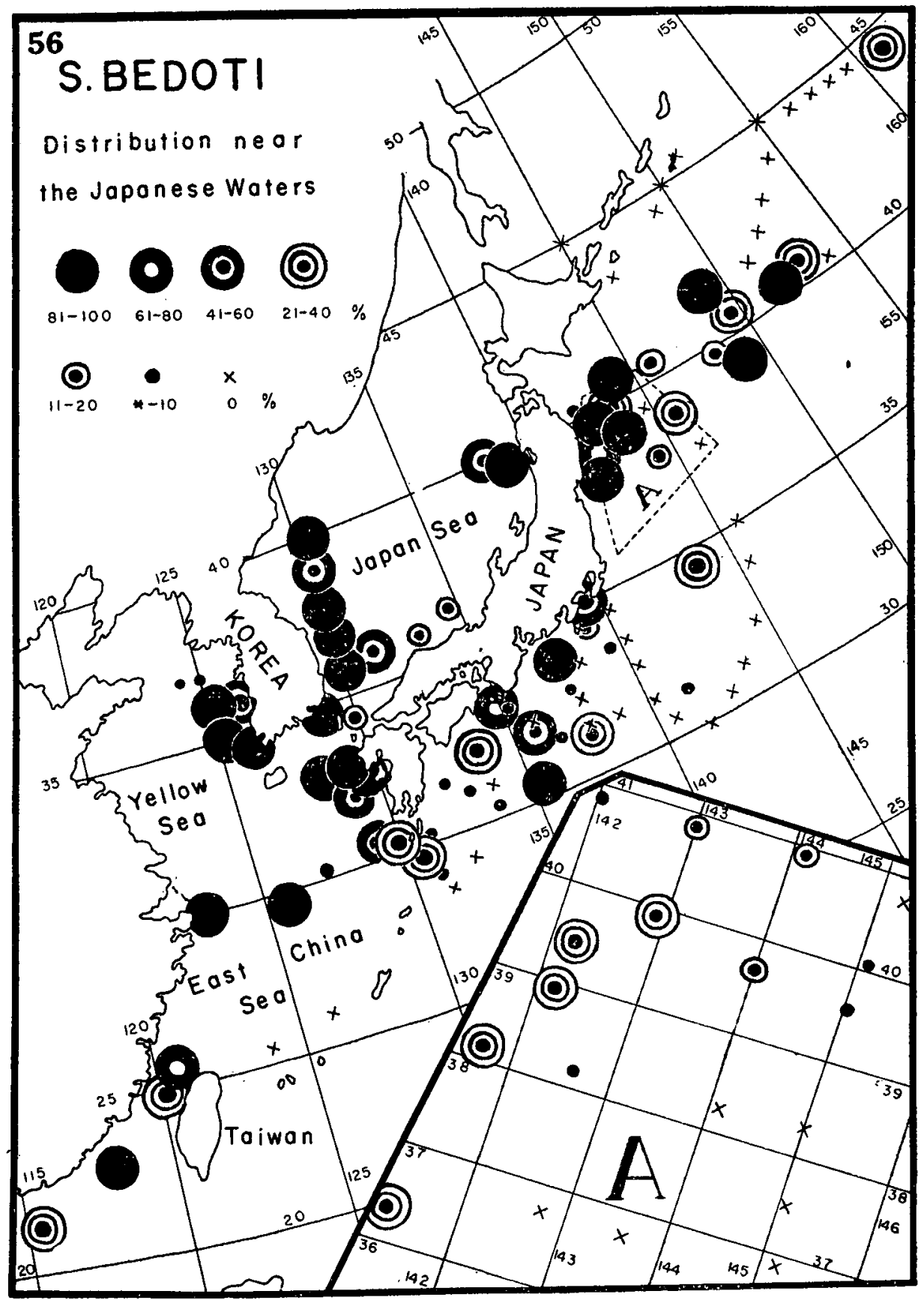

Fig. 26. Distribution of Sagitta bedoti in the Japanese and adjacent waters. 


\begin{tabular}{|c|c|c|c|c|c|c|c|}
\hline Stations & $\begin{array}{c}\text { Number } \\
\text { of ind. }\end{array}$ & $\%$ & $\frac{\text { bed. }}{\text { enf. }}$ & Stations & $\begin{array}{c}\text { Number } \\
\text { of ind. }\end{array}$ & $\%$ & $\frac{\text { bed. }}{\text { enf. }}$ \\
\hline TP 59A & 6 & 27 & $\infty$ & TP 76 & 60 & 29 & 2.61 \\
\hline TP 69 & 12 & 34 & $\infty$ & TP 78 & 58 & 32 & 6.44 \\
\hline TP 70 & 3 & 19 & 1.50 & TP 93 & 1 & 1 & 0.02 \\
\hline TP 71 & 3 & 11 & $\infty$ & TP 95 & 2 & 2 & 0.08 \\
\hline TP 74 & 6 & 4 & 0.33 & TP 99 & 2 & 1 & 0.04 \\
\hline
\end{tabular}

Table 29. Occurrence of $S$. bedoti at the western stations of the Transpac Expedition near Japan.

\begin{tabular}{|c|c|c|c|c|c|c|c|}
\hline Stations & $\begin{array}{l}\text { Number } \\
\text { of ind. }\end{array}$ & $\%$ & $\frac{\text { bed. }}{\text { enf. }}$ & Stations & $\begin{array}{l}\text { Number } \\
\text { of ind. }\end{array}$ & $\%$ & $\frac{\text { bed. }}{\text { enf. }}$ \\
\hline J 1 & 16 & 6 & 0.73 & J 8 & 1 & 33 & $\infty$ \\
\hline J 2 & 1 & 13 & $\infty$ & J 9 & 4 & 25 & $\infty$ \\
\hline J 3 & 1 & 17 & $\infty$ & $\mathrm{J} 10$ & 2 & 25 & 2.00 \\
\hline J 5 & 2 & 9 & 2.00 & $\mathrm{~J} 11$ & 9 & 23 & 9.00 \\
\hline J 6 & 1 & 3 & 0.33 & $\mathrm{~J} 12$ & 1 & 3 & 0.50 \\
\hline J 7 & 18 & 16 & 3.00 & J 19 & 17 & 24 & 1.42 \\
\hline
\end{tabular}

Table 30. Occurrence of $S$. bedoti in the material collected by a Japanese survey ship in the offshore waters off North-Eastern Honsyâ, Japan.

\section{1}

\begin{tabular}{|c|c|c|}
\hline $\begin{array}{c}\text { Percentage of } \\
\text { S. bedoti }\end{array}$ & $\begin{array}{c}\text { Eastern } \\
\text { Pacific }\end{array}$ & $\begin{array}{c}\text { Western } \\
\text { Pacific }\end{array}$ \\
\hline$*-5 \%$ & 22 & 6 \\
\hline $6-10 \%$ & 1 & 2 \\
\hline $11-20 \%$ & 3 & 5 \\
\hline $21-30 \%$ & 1 & 6 \\
\hline $31-40 \%$ & 0 & 3 \\
\hline total & 27 & 22 \\
\hline
\end{tabular}

* less than $1 \%$

Table 31. Comparison of the percentage of $S$. bedoti to the total chaetognaths between the eastern and western sides of the Pacific. 


\begin{tabular}{|c|c|c|c|c|c|}
\hline \multicolumn{2}{|c|}{ Eastern Pacific } & \multicolumn{3}{|c|}{ Western Pacific } \\
\hline$*$ & 5 & & $*$ & 0 & \\
\hline $0.01-0.09$ & 13 & \multirow{2}{*}{27} & $0.01-0.09$ & 3 & 7 \\
\hline $0.10-0.49$ & 6 & & $0.10-0.49$ & 2 & \\
\hline $0.50-0.99$ & 3 & & $0.50-0.99$ & 2 & \\
\hline $1.00-4.99$ & 0 & & $1.00-4.99$ & 6 & \\
\hline $5.00-9.99$ & 0 & 0 & $5.00-9.99$ & 2 & 15 \\
\hline $10.00-\infty$ & 0 & & $10.00-\infty$ & 7 & \\
\hline total & & & & & \\
\hline
\end{tabular}

Table 32. Frequency of occurrence of respective values of the ratio bedoti/enfita in the eastern and western sides of the Pacific. * less than 0.01

rence of this species off the Pacific coast of middle Japan (UYENo and Furuhashi 1955 and others) and off northeastern Japan (MARUMo 1955 and others). I found $S$. bedoti in 10 of the Transpac samples form the stations near Japan and in 12 of the 19 samples (Frequency of Occurrence 63\%) collected off north-eastern Japan by a Japanese survey ship and presented to the Transpac Expedition of Scripps Institution. As the samples were collected with small net, only a small number of this species occurred in the samples. However, when the proportion of this species is referred to total chaetognaths higher percentages seem to occur more frequently in the western than in the eastern Pacific (Table 31); and this tendency is more pronounced when the values of bedoti/enflata are computed and compared with those in the eastern Pacific (Table 32). The northern-most latitude where this sagitta occurred was $44^{\circ} 06^{\prime} \mathrm{N}$ and the eastern-most limit of the distribution was $161^{\circ} 39^{\prime} \mathrm{E}$,

\section{Other available data concerning the occurrence of $S$. bedoti.}

a) The waters around Japan.

i. Off north-eastern Honsya, north to $40^{\circ} \mathrm{N}$. (Table 33). The results of the examination of plankton samples collected by the Sôyô-Maru, a survey ship of the former Central Fisheries Experimental Station in Tôkyô, in the years 1934 and 1937-39 (TокіокA', 1957) show that $S$. bedoti occurred commonly in the mixing area of the cold Oyasio and the warm Kurosio in the southern part of this area. Here this species constitutes high percentages of the population, 33-100\%, the average being 84\%. The northern-most station where $S$. bedoti occurred in this material was $42^{\circ} 05^{\prime}$ $\mathrm{N}$ and the eastern-most station was $154^{\circ} 14^{\prime} \mathrm{E}$.

ii. Off north-eastern Honsyû, south to $40^{\circ} \mathrm{N}$. (Table 33). All of the seven samples mentioned in the preceding section, which were collected in this area, contained a large number of S. bedoti; its percentage was also very high ranging from 15 to $100 \%$ 


\begin{tabular}{|c|c|c|c|c|}
\hline Percentage & \multicolumn{2}{|c|}{ North to $40^{\circ} \mathrm{N}$} & \multicolumn{2}{|c|}{ South to $40^{\circ} \mathrm{N}$} \\
\hline$*-5 \%$ & - & & - & \\
\cline { 1 - 2 } & - & & - & \multirow{2}{*}{2} \\
\hline $11-20 \%$ & - & 1 & 1 & \\
\hline $21-30 \%$ & - & & 1 & \\
\hline $31-40 \%$ & 1 & & - & \\
\hline $41-50 \%$ & - & & - & \\
\hline $51-60 \%$ & - & & - & \\
\hline $61-70 \%$ & - & & 1 & \\
\hline $71-80 \%$ & - & 5 & - & 5 \\
\hline $81-90 \%$ & 2 & & - & \\
\hline $91-100 \%$ & 3 & & 4 & \\
\hline total & & 6 & & 7 \\
\hline
\end{tabular}

Table 33. Occurrence of $S$. bedoti in the waters off North-Eastern Honsyâ, Japan (Sôyô-Maru material). * present, but less than $1 \%$.

\begin{tabular}{|c|c|c|c|c|}
\hline Percentage & $\begin{array}{l}\text { off the } \\
\text { Westerr }\end{array}$ & $\begin{array}{l}\text { South- } \\
\text { Honsyû }\end{array}$ & & \\
\hline$*-5 \%$ & 3 & \multirow{6}{*}{9} & - & \multirow{6}{*}{4} \\
\hline $6-10 \%$ & 2 & & - & \\
\hline $11-20 \%$ & 1 & & 2 & \\
\hline $21-30 \%$ & 2 & & 1 & \\
\hline $31-40 \%$ & - & & 1 & \\
\hline $41-50 \%$ & 1 & & - & \\
\hline $51-60 \%$ & - & \multirow{4}{*}{3} & 2 & \multirow{4}{*}{2} \\
\hline $61-70 \%$ & - & & - & \\
\hline $71-80 \%$ & 2 & & 一 & \\
\hline $81-90 \%$ & 1 & & - & \\
\hline total & \multicolumn{2}{|c|}{12} & \multicolumn{2}{|c|}{6} \\
\hline
\end{tabular}

Table 34. Occurrence of $S$. bedoti in the waters off South-Western Honsyû, Japan (Sôyô-Maru material). * present, but less than $1 \%$. 
and $71 \%$ on an average. The greater part of this area is one of mixing between the Oyasio and the Kurosio, and the abundance of S. bedoti along the boundary between these two water-masses in this area has also been reported in the oceanographic reports (Kaiyô-Hôkoku) published by the Meteorological Department of Japan (19561958). MARumo (1955) stated that S. bedoti was comparatively abundant in the Kurosio and in the area where the Oyasio and the Kurosio mingle. This is clearly illustrated also by BIERI (1959).

\begin{tabular}{|c|c|c|c|c|c|c|c|c|c|c|c|c|c|}
\hline & \multicolumn{5}{|c|}{ Coastal Water } & \multicolumn{6}{|c|}{ Proper part of Kurosio } & \multicolumn{2}{|c|}{$\begin{array}{c}\text { offshore } \\
\text { water } \\
\text { beyond Kurosio } \\
\end{array}$} \\
\hline Stations & \multicolumn{5}{|c|}{$\mathrm{I}_{\mathbf{1}}$} & \multicolumn{2}{|c|}{$\mathrm{I}_{2}$} & \multicolumn{2}{|r|}{$\mathrm{I}_{3}$} & \multicolumn{2}{|r|}{$\mathrm{I}_{4}$} & \multicolumn{2}{|c|}{$I_{5}$} \\
\hline Aug. 1954 & \multicolumn{5}{|c|}{2} & \multicolumn{2}{|c|}{4} & & 2 & \multicolumn{2}{|r|}{0} & \multicolumn{2}{|c|}{-} \\
\hline Oct. 1954 & \multicolumn{5}{|c|}{0} & \multicolumn{2}{|c|}{0} & & 0 & \multicolumn{2}{|r|}{0} & \multicolumn{2}{|c|}{0} \\
\hline Mar. 1955 & \multicolumn{5}{|c|}{20} & \multicolumn{2}{|c|}{0} & & 0 & \multicolumn{2}{|c|}{0} & \multicolumn{2}{|c|}{0} \\
\hline Stations & \multicolumn{5}{|c|}{$\mathrm{I}_{2}^{\prime}$} & \multicolumn{3}{|c|}{$I_{3}^{\prime}$} & \multicolumn{3}{|c|}{$\mathrm{I}_{4}{ }^{\prime}$} & \\
\hline Oct. 1954 & \multicolumn{5}{|c|}{0} & \multicolumn{3}{|c|}{4} & \multicolumn{3}{|c|}{0} & & \\
\hline Stations & \multicolumn{2}{|c|}{$\mathrm{J}_{1}$} & \multicolumn{2}{|l|}{$\mathbf{J}_{2}$} & $\mathrm{~J}_{3}$ & \multicolumn{2}{|c|}{$\mathrm{J}_{4}$} & & $J_{5}$ & & $\mathrm{~J}_{6}$ & \multicolumn{2}{|c|}{$\mathrm{J}_{7}$} \\
\hline Aug.-Sept. 1954 & 4 & & 1 & & 4 & & 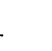 & & 0 & & 0 & & \\
\hline Oct. 1954 & 0 & & 0 & & 0 & & 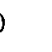 & & 0 & & 0 & & - \\
\hline Stations & & & $\mathrm{K}$ & & & $\mathrm{K}_{2}$ & $\mathrm{~K}$ & & $\mathrm{~K}_{4}$ & $\mathrm{~K}_{5}$ & $\mathrm{~K}_{6}$ & & 7 \\
\hline May 1954 & & & - & & & - & - & & - & - & 0 & & - \\
\hline Aug.-Sept. 1954 & & & 2 & & & 0 & & 1 & & 0 & 0 & & 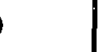 \\
\hline Oct. 1954 & & & 8 & & & 0 & 0 & & 0 & 0 & 0 & & - \\
\hline Stations & & & $\mathrm{G}_{1}$ & & & $\mathrm{G}_{2}$ & $\mathrm{G}$ & & $\mathrm{G}_{4}$ & $\mathrm{G}_{5}$ & $\mathrm{G}_{6}$ & $\mathrm{G}_{7}$ & $\mathrm{G}_{8}$ \\
\hline May 1954 & & & 11 & & & 13 & 0 & 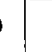 & 4 & 0 & 0 & 0 & - \\
\hline Aug.-Sept. 1954 & & & 33 & & & 1 & 0 & & 0 & 0 & 0 & 0 & 3 \\
\hline Oct. 1954 & & & 4 & & & 4 & 0 & & 0 & 0 & 8 & - & - \\
\hline Mar. 1955 & & & 0 & & & 0 & 96 & & 0 & 0 & 0 & - & - \\
\hline Stations & $\mathrm{H}_{1}$ & $\mathrm{H}_{2}$ & $\mathrm{H}_{3}$ & $\mathrm{H}_{4}$ & $\mathrm{H}_{5}$ & & $\mathrm{H}_{6}$ & & & $\mathrm{H}_{7}$ & & & \\
\hline Mar. 1955 & 16 & 8 & 32 & 16 & 0 & & 0 & & & 0 & & & \\
\hline Stations & $\mathrm{U}_{1}$ & $\mathrm{U}_{10}$ & $\mathrm{U}_{11}$ & $\mathrm{U}_{12}$ & $\mathrm{U}_{13}$ & $\mathrm{U}_{2}$ & $\mathrm{U}_{3}$ & $\mathrm{U}_{4}$ & $\mathrm{U}_{7}$ & $\mathrm{U}_{8}$ & $\mathrm{U}_{9}$ & $\mathrm{U}_{5}$ & $\mathrm{U}_{6}$ \\
\hline Aug.-Sept. 1954 & 12 & 8 & 0 & 0 & 4 & 0 & 6 & 0 & 0 & 8 & 8 & 0 & 4 \\
\hline
\end{tabular}

Table 35. Individual number of $S$. bedoti occurred at respective stations in the Kurosio area off the South-Western Honshû, Japan. (Data offered by the Kôbe Marine Observatory.) 


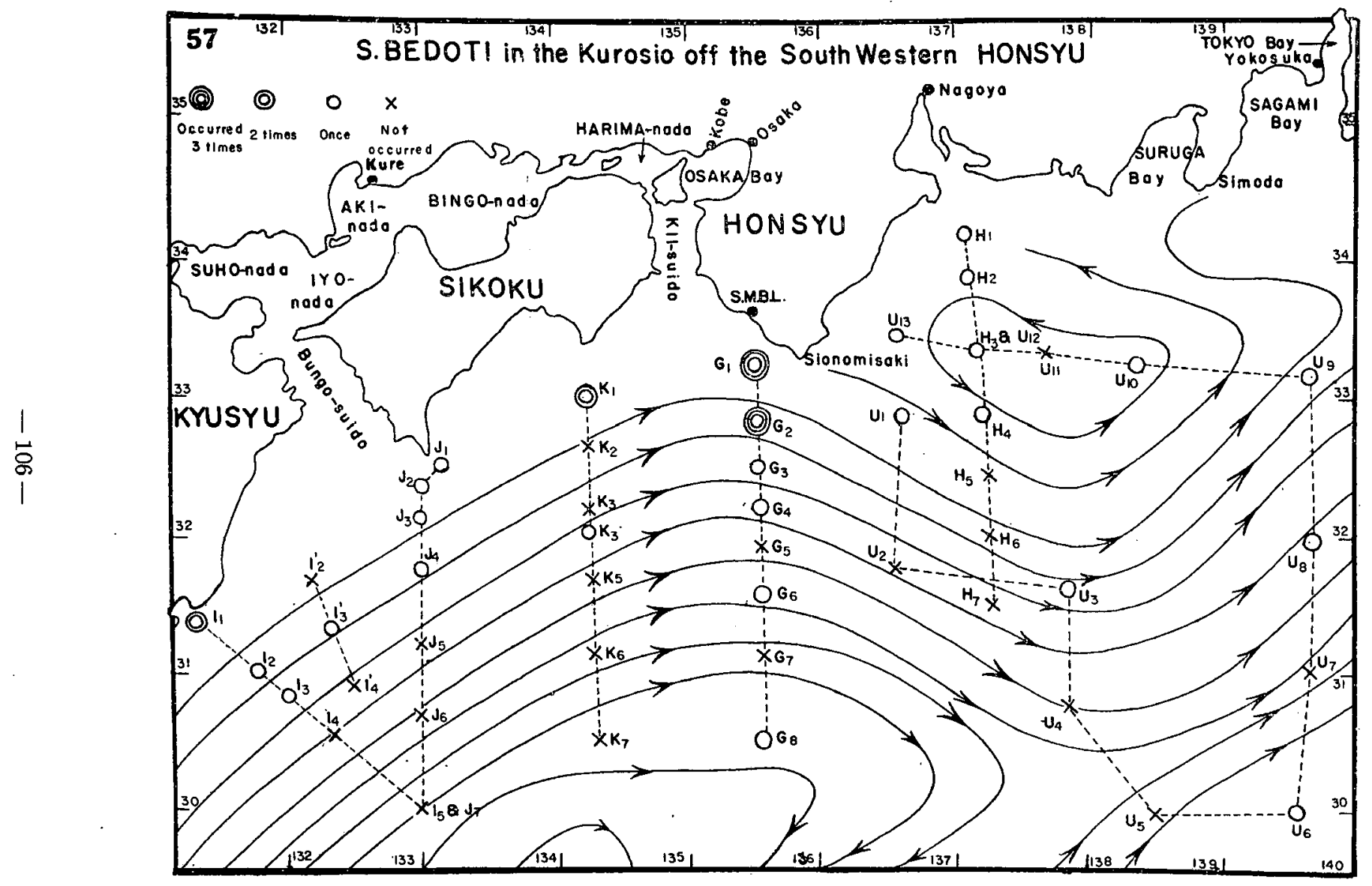

Fig. 27. Occurrence of Sagitta bedoti in the Kurosio region off the South Western Honsya, Japan. 
iii. Off south-western Honsyû. (Fig. 27, Tables 34-38). In 12 of the 13 samples of the Sôyô-Maru material (Frequency of Occurrence 92\%), collected in this area, from 2 to $82 \%$ of the chaetognath population consisted of $S$. bedoti (31\% on an average) (Table 34). Here, S. bedoti appeared to occur more abundantly in the eastern part of this area than in the western part near Kyûsyâ.

Concerning the distribution of $S$. bedoti in the southern waters off Honsyâ, UyENo and Furuhashi (1955a and 1955b) showed that this species occurred in the coastal part of the Kurosio and in the axial portion (the most strongly flowing portion) of the current, but it was quite absent in the counter current of the Kurosio far beyond the axial portion. Prior to reading these papers, I asked to $\mathrm{Mr}$. Furuhashr of the Kôbe Marine Observatory to let me see the data to ascertain the details of the occurrence of this species. Very kindly, Mr. Furuhashi sent me the detailed data and allowed me so generously to quote and publish them in my paper in his letter of

36

Table 36. Occurrence of S. bedoti in Tôkyô Bay (MurakamI, 1957). * present, but less than $1 \%$.

\begin{tabular}{|c|c|c|c|c|c|}
\hline Outer part & $\begin{array}{c}\text { May 15-17 } \\
1947\end{array}$ & $\begin{array}{c}\text { Sept. 11-13 } \\
1947\end{array}$ & $\begin{array}{c}\text { Nov. 19-22 } \\
1947\end{array}$ & $\begin{array}{c}\text { Dec. 6-7 } \\
1947\end{array}$ & $\begin{array}{c}\text { Mar. 17 } \\
1948\end{array}$ \\
\hline 0 & 3 & 8 & 6 & 4 & 2 \\
\hline$*-5 \%$ & 2 & - & - & - & - \\
\hline $6-10 \%$ & 2 & - & 2 & - & - \\
\hline $11-20 \%$ & - & - & 3 & 1 & - \\
\hline $21-30 \%$ & 1 & - & 1 & 1 & - \\
\hline $31-40 \%$ & - & - & 2 & 1 & - \\
\hline $41-50 \%$ & - & - & 3 & - & - \\
\hline $51-60 \%$ & - & - & 1 & 1 & 0 \\
\hline Occurrence & 5 & 0 & 12 & 4 & - \\
\hline mean & 10 & - & 30 & 33 & - \\
\hline
\end{tabular}

Table $36-1$

\begin{tabular}{|c|c|c|c|c|}
\hline Central part & $\begin{array}{c}\text { May 13-15 } \\
1947\end{array}$ & $\begin{array}{c}\text { Sept. 9-11 } \\
1947\end{array}$ & $\begin{array}{c}\text { Dec. 4-6 } \\
1947\end{array}$ & $\begin{array}{c}\text { Mar. 12-17 } \\
1948\end{array}$ \\
\hline 0 & 15 & 15 & 10 & 13 \\
\hline$*-5 \%$ & - & - & 3 & 2 \\
\hline $6-10 \%$ & - & - & 2 & - \\
\hline Occurrence & 0 & 0 & 5 & 2 \\
\hline mean & - & - & 4 & 2 \\
\hline
\end{tabular}

Table $36-2$ 


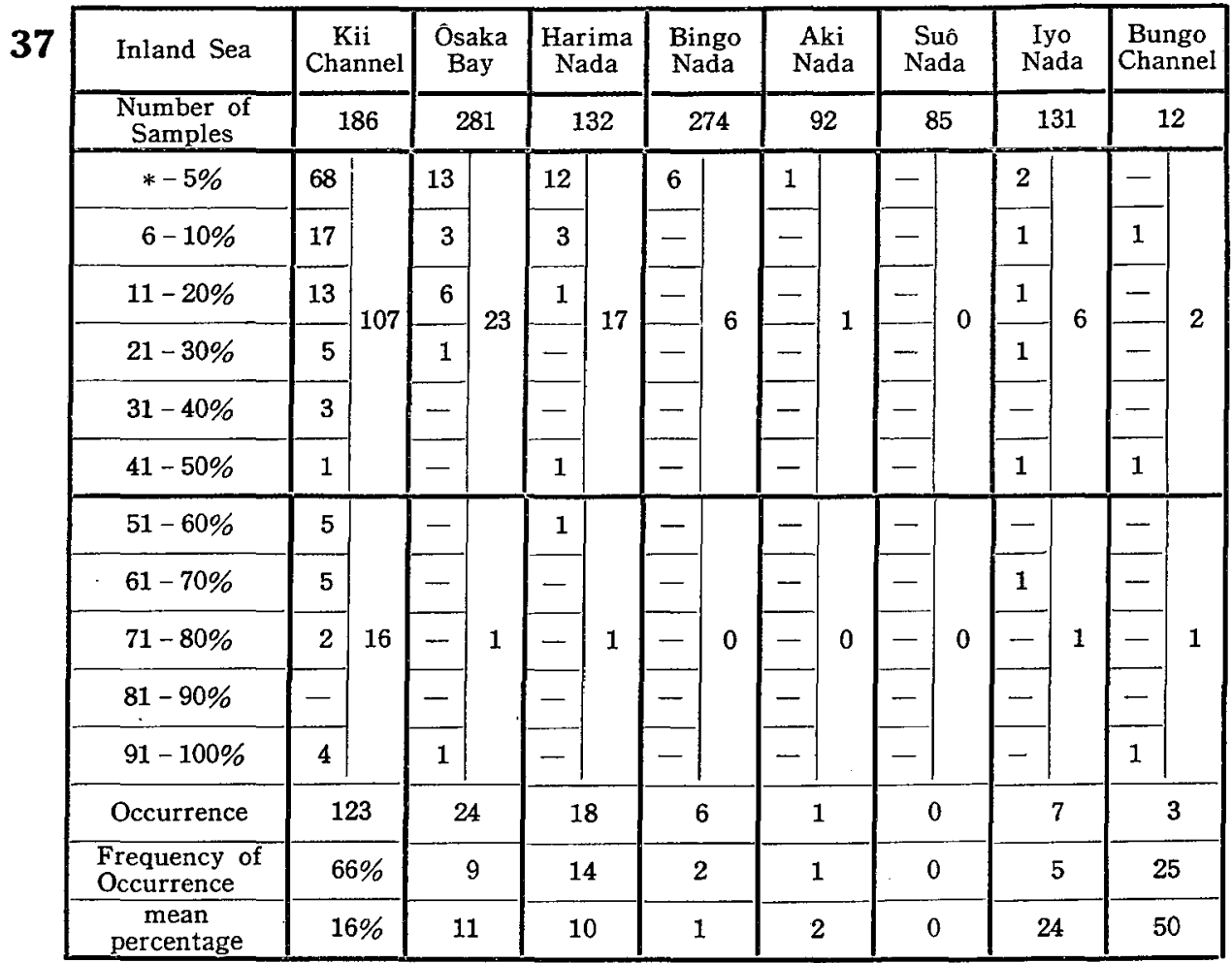

Table 37. Occurrence of $S$. bedoti in the Inland Sea (MURAKaMr, 1957 and 1959). * present, but less than $1 \%$.

\section{8}

\begin{tabular}{|c|c|}
\hline \multicolumn{2}{|c|}{ Osaka Bay 1938} \\
\hline $\begin{array}{c}\text { Number of } \\
\text { Stations } \\
*-5 \%\end{array}$ & 36 \\
\hline $6-10 \%$ & 11 \\
\hline Occurrence & 13 \\
\hline $\begin{array}{c}\text { Frequency of } \\
\text { Occurrence }\end{array}$ & $36 \%$ \\
\hline $\begin{array}{c}\text { mean } \\
\text { Percentage }\end{array}$ & $3 \%$ \\
\hline
\end{tabular}

Table 38. Occurrence of $S$. bedoti in Osaka Bay (TokiokA, 1939).

* present, but less than $1 \%$.
May 9, 1955. Moreover, he stated in his letter of July 6,1955 that $S$. bedoti seemed to disappear in the waters 40-50 miles off Sionomisaki. All the samples were collected from $100 \mathrm{~m}$ to the surface with the 0 -net of the Kôbe Marine Observatory, constructed of No. 3 gauze and with the diameter of the mouth adjusted so as to cut $1 / 10 \mathrm{~m}^{2}$. S. bedoti occurred in 17 of 29 samples (Frequency of Occurrence 59\%) obtained in the coastal waters, in 14 of 58 samples from the proper part of the Kurosio (Frequency of Occurrence 24\%) and in 2 of 9 samples from the offshore waters beyond the proper part of the Kurosio (Frequency of Occurrence $22 \%$ ) (Table 35). The average number of specimens per haul was 10.9 in the coastal water, 4.8 (excluding the unusual occurrence of 96 individuals at $G_{3}$ in March 1955) in the axial part of the Kurosio and 3.5 in the offshore water beyond the Kurosio. It is evident that the species is found abundantly 
near the coast and diminishes markedly towards the open sea, although some small masses of the coastal water containing many $S$. bedoti may be carried, across the Kurosio, into the more offshore waters beyond the current by some counter currents and contrarily some masses of the far offshore water containing few S. bedoti may drift just near the shore of the Pacific coast of middle Japan.

In addition to the coastal waters of this region of Japan, S. bedoti is found in the following localities :

A) Sagami bay (Table 34). The first record of $S$. bedoti in Japanese waters was in Misaki Harbour in Sagami Bay by AIDA (1897) under the name of S. bipunctata.

All of the six samples of the Soyo-Maru material collected in this bay included this species which constituted from 13 to $53 \%$ (33\% on an average) of the total chaetognaths. While I was working at the Mitsui Institute of Marine Biology in 193738 , I very frequently collected chaetognaths from the surface water of Sagami and Suruga bays, near the laboratory of the Institute, by using KITAHARA's quantitative net. In this material, I found about $1300 \mathrm{~S}$. bedoti, this was approximatately $16 \%$ of all chaetognaths collected.

B) Tôkyô Bay (Table 36). Murakami (1957) made a series of observations on the distribution of chaetognaths in this bay in the years 1947-48. When the bay is divided into three areas, an inner part inside a line connecting the estuaries of the River Rokugô and the River Yôrô, an outer part outside a line connecting the capes of Kannon-saki and Futtu-saki and a central part between these two, S. bedoti occurred most frequently (Frequency of Occurrence 48\%) in the outer part and less frequently (Frequency of Occurrence 12\%) in the central part, but it did not occur in any of the twenty-eight samples hauled in the inner part. The percentage of $S$. bedoti to the total chaetognaths ranged from 2 to 57 in the outer part, but from 1 to 8 in the middle portion. Higher percentages of the chaetognath population in the inner and middle portions are made up of $S$. crassa and its form naikaiensis.

C) Inland Sea and adjacent areas (Tables 37-38, see also Fig. 27). Murakami (1957 and 1959) gives details of the occurrence of chaetognaths in vast plankton samples collected in the Inland Sea and adjacent areas in the years 1951-1957. His data on $S$. bedoti are arranged here in Table 37 so as to show its abundance in respective sections of the area under consideration. S. bedoti enters the Inland Sea from both $\mathrm{Kii}$ and Bungo Channels, but diminishes markedly towards the middle part of the Sea, where S. crassa and especially its forma naikaiensis are very abundant. In Kii-Channel the precentage of $S$. bedoti is very often much lowered by dense population of S. enflata. I made four hauls in Kii-Channel in 1938; S. bedoti occurred in three of these samples, its percentage varies from 3 to 20,13 on an average (1939). In February 1954, a dense patch of chaetognaths appeared near the Seto Marine Biological Laboratory facing Kii-Channel, a small part of this patch was collected and 13 species were identified in 1112 specimens. Among these only five individuals of $S$. bedoti occurred (ТокІокA, 1954a). In Osaka Bay, this species occurs 
39

\begin{tabular}{|c|c|c|c|c|}
\hline $\begin{array}{c}\text { Southern Waters } \\
\text { off Kyusyu }\end{array}$ & Tokx & 1940 & $\begin{array}{l}\mathrm{Ma} \\
\text { Sôy }\end{array}$ & \\
\hline $\begin{array}{l}\text { Number of } \\
\text { Samples }\end{array}$ & \multicolumn{2}{|c|}{16} & \multicolumn{2}{|c|}{6} \\
\hline$*-5 \%$ & 1 & \multirow{6}{*}{11} & 2 & \multirow{6}{*}{4} \\
\hline $6-10 \%$ & 3 & & - & \\
\hline $11-20 \%$ & 4 & & - & \\
\hline $21-30 \%$ & 2 & & - & \\
\hline $31-40 \%$ & 1 & & 2 & \\
\hline $41-50 \%$ & - & & - & \\
\hline $51-60 \%$ & $\mathbf{1}$ & 1 & - & 0 \\
\hline Occurrence & & & & \\
\hline $\begin{array}{l}\text { Frequency of } \\
\text { Occurrence }\end{array}$ & & & & \\
\hline $\begin{array}{c}\text { mean } \\
\text { Percentage }\end{array}$ & & & & \\
\hline
\end{tabular}

Table 39. Occurrence of $S$. bedoti in the waters off Southern Kyûsyù, Japan.

* present, but less than $1 \%$.
40

\begin{tabular}{|c|c|c|}
\hline \multicolumn{3}{|c|}{ Western Waters off Kyûsya } \\
\hline $\begin{array}{c}\text { Number of } \\
\text { Samples }\end{array}$ & & \\
\hline$*-5 \%$ & 1 & \multirow{5}{*}{2} \\
\hline $6-10 \%$ & - & \\
\hline $11-20 \%$ & - & \\
\hline $21-30 \%$ & - & \\
\hline $31-40 \%$ & 1 & \\
\hline $41-50 \%$ & - & \\
\hline $51-60 \%$ & $\overline{2}$ & \multirow{5}{*}{6} \\
\hline $61-70 \%$ & 1 & \\
\hline $71-80 \%$ & 二 & \\
\hline $81-90 \%$ & 1 & \\
\hline $91-100 \%$ & 2 & \\
\hline Occurrence & \multicolumn{2}{|c|}{8} \\
\hline $\begin{array}{l}\text { Frequency of } \\
\text { Occurrence }\end{array}$ & \multicolumn{2}{|c|}{$89 \%$} \\
\hline $\begin{array}{c}\text { mean } \\
\text { Percentage }\end{array}$ & \multicolumn{2}{|c|}{$62 \%$} \\
\hline
\end{tabular}

Table 40. Occurrence of $S$ bedoti in the waters off Western Kyasyû, Japan. (ToKIOKA, 1940).

* present, but less thun $1 \%$.

more abundantly in the western half along Awazi Island. Of 36 samples hauled in 1938 in Ôsaka Bay by myself, S. bedoti occurred in 13 samples (Frequency of Occurrence $36 \%$ ) and its percentage varied from 1 to 10 . It occurred mostly near the south-western and north-western channels leading respectively to Kii-Channel and Harima-Nada (TokiokA, 1939). The species has never been found in any of the small embayments situated in the central part of the Inland Sea. For instance, none of the 31 plankton samples hauled in Kaida Bay in the years 1950-1951 nor 115 samples hauled in Kasaoka Bay in the years 1952-53 contained S. bedoti (Murakami, 1957).

iv. The southern waters off Kyûsyû (Table 39). The data found in my previous paper (1940) and those of the Sôyô-Maru material (TokiokA, 1957) are available. The highest percentage was $59 \%$ found in the data of 1940 . The density of S. bedoti seems to fluctuate rather violently in this area.

v. The western waters off Kyûsyû (Table 40). Only the data found in my paper of 1940 are available at present.

vi. The Korea Straits (Table 42). The data in my paper of 1940 show that S. bedoti is abundant in this area as well as in the Japan Sea.

vii. The Japan Sea (Table 41). The samples dealt with in my paper of 1940 were collected mostly along the eastern coast of Korea, not far from the land. All the data quoted in Table 41 are from samples collected at stations situated in the warm water region of the Japan Sea. At stations in the mixing area between the cold 


\begin{tabular}{|c|c|c|c|c|c|c|c|c|}
\hline The Japan Sea & \multicolumn{2}{|c|}{ TokIOKA 1940} & \multicolumn{2}{|c|}{$\begin{array}{l}\text { TokIoKA } 1951 \\
\text { Surface hauls }\end{array}$} & \multicolumn{2}{|c|}{$\begin{array}{l}\text { TOKIOKA } 1951 \\
50 \sim 350 \mathrm{~m} \text { to } 0 \mathrm{~m}\end{array}$} & \multicolumn{2}{|c|}{ FURUHASHI 1953} \\
\hline $\begin{array}{c}\text { Number of } \\
\text { Samples }\end{array}$ & \multicolumn{2}{|c|}{21} & \multicolumn{2}{|c|}{66} & \multicolumn{2}{|c|}{35} & \multicolumn{2}{|c|}{4} \\
\hline$*-5 \%$ & - & \multirow{6}{*}{5} & - & \multirow{6}{*}{3} & 10 & \multirow{6}{*}{32} & - & \multirow{6}{*}{4} \\
\hline $6-10 \%$ & - & & - & & 10 & & 1 & \\
\hline $11-20 \%$ & 1 & & 1 & & 3 & & 1 & \\
\hline $21-30 \%$ & 2 & & 1 & & 2 & & 2 & \\
\hline $31-40 \%$ & 1 & & 1 & & 5 & & - & \\
\hline $41-50 \%$ & 1 & & - & & 2 & & $\overline{-}$ & \\
\hline $51-60 \%$ & 3 & \multirow{5}{*}{16} & 二 & \multirow{5}{*}{2} & - & \multirow{5}{*}{1} & - & \multirow{5}{*}{0} \\
\hline $61-70 \%$ & 2 & & - & & - & & - & \\
\hline $71-80 \%$ & 1 & & - & & 1 & & - & \\
\hline $81-90 \%$ & 4 & & - & & - & & - & \\
\hline $91-100 \%$ & 6 & & 2 & & - & & - & \\
\hline Occurrence & \multicolumn{2}{|c|}{21} & \multicolumn{2}{|c|}{5} & \multicolumn{2}{|c|}{33} & \multicolumn{2}{|c|}{4} \\
\hline $\begin{array}{l}\text { Frequency of } \\
\text { Occurrence }\end{array}$ & \multicolumn{2}{|c|}{$100 \%$} & \multicolumn{2}{|c|}{$8 \%$} & \multicolumn{2}{|c|}{$94 \%$} & \multicolumn{2}{|c|}{$100 \%$} \\
\hline $\begin{array}{c}\text { mean } \\
\text { Percentage }\end{array}$ & \multicolumn{2}{|c|}{$68 \%$} & \multicolumn{2}{|c|}{$56 \%$} & \multicolumn{2}{|c|}{$17 \%$} & \multicolumn{2}{|c|}{$18 \%$} \\
\hline
\end{tabular}

Table 41. Occurrence of $S$. bedoti in the Japan Sea.

* present, but less than $1 \%$.

\begin{tabular}{|c|c|c|c|c|}
\hline \multirow{2}{*}{$\frac{42}{\substack{\text { Number of } \\
\text { Samples }}}$} & \multicolumn{2}{|c|}{ The Yellow Sea } & \multicolumn{2}{|c|}{ The Korea Straits } \\
\hline & \multicolumn{2}{|c|}{19} & \multicolumn{2}{|c|}{32} \\
\hline$*-5 \%$ & 3 & \multirow{6}{*}{5} & - & \multirow{6}{*}{10} \\
\hline $6-10 \%$ & $=$ & & 2 & \\
\hline $11-20 \%$ & - & & 2 & \\
\hline $21-30 \%$ & 1 & & 3 & \\
\hline $31-40 \%$ & - & & 2 & \\
\hline $41-50 \%$ & 1 & & 1 & \\
\hline $51-60 \%$ & - & \multirow{5}{*}{7} & 2 & \multirow{5}{*}{19} \\
\hline $61-70 \%$ & - & & 2 & \\
\hline $71-80 \%$ & - & & 1 & \\
\hline $81-90 \%$ & - & & 1 & \\
\hline $91-100 \%$ & 7 & & 13 & \\
\hline Occurrence & \multicolumn{2}{|c|}{12} & \multicolumn{2}{|c|}{29} \\
\hline $\begin{array}{l}\text { Frequency of } \\
\text { Occurrence }\end{array}$ & \multicolumn{2}{|c|}{$63 \%$} & \multicolumn{2}{|c|}{$91 \%$} \\
\hline $\begin{array}{c}\text { mean } \\
\text { Percentage }\end{array}$ & \multicolumn{2}{|c|}{$62 \%$} & \multicolumn{2}{|c|}{$69 \%$} \\
\hline
\end{tabular}

Table 42. Occurrence of $S$. bedoti in the Yellow Sea and the Korea Straits (ToKIOKA, 1940).

* present, but less than $1 \%$. 
Liman Current and the warm Tusima Current, S. bedoti constitutes fairly high proportion of the chaetognaths, although its percentage is often lowered by the dense population of S. minima.

b) The Yellow Sea (Table 42)

According to the data of the material treated in my previous paper of 1940, S. bedoti seems to be very abundant at stations in this sea except for northern stations and excluding the samples gathered in the very surface layer, where the salinity of the water is rather low and only S. crassa is dominant. In Table 42, only the data of samples collected at stations situated south of the latitude of the point of Shantung peninsula in North China are treated. Both the frequency of occurrence and the mean percentage should be much raised if more stations in the northern part are omitted from consideration.

c) The East China Sea (Table 43).

$S$. bedoti was very abundant at stations around the Chu-San Islands near the estuary of the Yang-Tse River (TokiokA, 1940). In the East China Sea, it seems to be very common in the western half near the continent, but gradually decreases towards the east and is scarcely found near the Ryakyô Islands. The Sôyô-Maru material con-

\begin{tabular}{|c|c|c|c|c|}
\hline The East China Sea & Sôyô-1 & aterial & $\begin{array}{r}\text { A } \\
\text { Chu }\end{array}$ & $\begin{array}{l}\text { the } \\
\text { lands }\end{array}$ \\
\hline $\begin{array}{l}\text { Number of } \\
\text { samples }\end{array}$ & \multicolumn{2}{|c|}{4} & \multicolumn{2}{|c|}{11} \\
\hline$*-5 \%$ & - & \multirow{6}{*}{1} & - & \multirow{6}{*}{1} \\
\hline $6-10 \%$ & 1 & & - & \\
\hline $11-20 \%$ & - & & - & \\
\hline $21-30 \%$ & - & & 1 & \\
\hline $31-40 \%$ & - & & - & \\
\hline $41-50 \%$ & - & & - & \\
\hline $51-60 \%$ & - & \multirow{5}{*}{1} & - & \multirow{5}{*}{10} \\
\hline $61-70 \%$ & - & & 1 & \\
\hline $71-80 \%$ & - & & - & \\
\hline $81-90 \%$ & - & & - & \\
\hline $91-100 \%$ & 1 & & 9 & \\
\hline Occurrence & \multicolumn{2}{|c|}{2} & \multicolumn{2}{|c|}{11} \\
\hline $\begin{array}{l}\text { Frequency of } \\
\text { Occurrence }\end{array}$ & \multicolumn{2}{|c|}{$50 \%$} & \multicolumn{2}{|c|}{$100 \%$} \\
\hline $\begin{array}{c}\text { mean } \\
\text { Percentage }\end{array}$ & \multicolumn{2}{|c|}{$50 \%$} & \multicolumn{2}{|c|}{$88 \%$} \\
\hline
\end{tabular}

Table 43. Occurrence of $S$. bedoti in the East China Sea. * present, but less than $1 \%$. 
tains two samples from the Taiwan Straits, in both of which $S$. bedoti occupies very high percentage, respectively 54 and $21 \%$. Mr. ENомото of the Seikai Regional Fisheries Research Laboratory at Nagasaki stated in his letter of March 27, 1957 that this sagitta seemed to be the most important of all chaetognaths in the East China Sea, when he sent me several specimens of $S$. bedoti for identification, which were collected in June 1956 near the middle of that sea.

d) The South China Sea (Table 44)

In this area, $S$. bedoti maintains still higher percentages in the north-western portion (18$81 \%$ ), but decreases greatly near Hainan Island (less than 3\%). It is recorded also from the coastal waters of Annan (SERENE, 1937), but there it forms only a small part of the chaetognath fauna (HAMON, 1956). The minor form occurred in the Bay of Nhatrang-Cauda at a frequency of $6-76 \%$, but it occupied only less than $1.7 \%$ of the whole population.

\section{e) The waters around the Philippines and adjacent waters (Tables 45-46)}

44

\begin{tabular}{|c|c|c|}
\hline \multicolumn{3}{|c|}{ The South China Sea } \\
\hline $\begin{array}{c}\text { Number of } \\
\text { samples }\end{array}$ & & \\
\hline$*-5 \%$ & 3 & \multirow{6}{*}{5} \\
\hline $6-10 \%$ & - & \\
\hline $11-20 \%$ & 1 & \\
\hline $21-30 \%$ & 1 & \\
\hline $31-40 \%$ & - & \\
\hline $41-50 \%$ & - & \\
\hline $51-60 \%$ & 一 & \multirow{4}{*}{1} \\
\hline $61-70 \%$ & - & \\
\hline $71-80 \%$ & - & \\
\hline $81-90 \%$ & 1 & \\
\hline Occurrence & \multicolumn{2}{|c|}{6} \\
\hline $\begin{array}{c}\text { Frequency of } \\
\text { Occurrence }\end{array}$ & \multicolumn{2}{|c|}{$67 \%$} \\
\hline $\begin{array}{c}\text { mean } \\
\text { Percentage }\end{array}$ & \multicolumn{2}{|c|}{$22 \%$} \\
\hline
\end{tabular}

Table 44. Occurrence of $S$. bedoti in the South China Sea (Sôyô-maru material). * present, but less than $1 \%$.

According to Michael (1919), during the Philippine Expedition by the Albatross, $S$. bedoti occurred at only four stations in the Sulu Sea and adjacent waters. The frequency of occurrence was $9 \%$ of the total 46 sampling stations.

The south-eastern waters off Mindanao (Mindanao Current): During the Snellius

\begin{tabular}{|c|c|c|c|}
\hline Sulu Sea & $\begin{array}{c}\text { Number of } \\
\text { Sampling Sts. }\end{array}$ & $\begin{array}{c}\text { Frequency of } \\
\text { Occurrence }\end{array}$ & $\begin{array}{c}\text { mean } \\
\text { Percentage }\end{array}$ \\
\hline SibOGA-Exped. & 5 & $60 \%$ & $6.1(1$ station $)$ \\
\hline SNELLIUS-Exped. & 6 & $83 \%$ & $4(1 \sim 5 \%)$ \\
\hline
\end{tabular}

Table 45. Occurrence of $S$. bedoti in the Sulu Sea.

\begin{tabular}{|l|c|c|c|}
\hline Mindanao Current & $\begin{array}{c}\text { Number of } \\
\text { Sampling Sts. }\end{array}$ & $\begin{array}{c}\text { Frequency of } \\
\text { Occurrence }\end{array}$ & $\begin{array}{c}\text { mean } \\
\text { Percentage }\end{array}$ \\
\hline SIBOGA-Exped. & 2 & $50 \%$ & + \\
\hline SNELLIUS-Exped. & 30 & $43 \%$ & $2 \%\left(\begin{array}{c}* \ldots \ldots \ldots 2 \\
1-5 \% \cdots 11\end{array}\right.$ \\
\hline
\end{tabular}

Table 46. Occurrence of $S$. bedoti in the south-eastern waters off Mindanao. * less than $1 \%$. 
Expedition, the frequency of occurrence of this species was higher in the southern part than in the northern part of this area.

f) The waters around the Malay Archipelagoes (Tables 47-51).

Since BÉRANECK's (1895) original description of $S$. bedoti was published, stating that-"It is abundant in the bay of Amboina (p. 152)"-, there have been published three important paper: FowLeR's report on the material of Siboga-Expedition (1906), OYE's paper on the chaetognaths of the Java Sea (1918) and ScHILP's extensive work on the material of the Snellius Expedition (1941). According to OYE's data, S. bedoti seems to be more abundant in the western part than in the eastern part of the Java Sea.

g) The waters adjacent to the above-mentioned area (Tables 52 and 53).

The stations of the Snellius Expedition in the Arafura Sea were situated in the north-western part of the sea, while ToKIOKA's material came from the south-western part of the sea. Besides, TokrokA (1942) states that S. bedoti was common in the plankton samples taken near the estuary of the River Liverpool, Arnhem Land.

h) The Indian Ocean (Fig. 28, Table 54).

The record of Sagitta polyodon by DONCASTER (1903) from the waters around the Maldive Islands is the first one dealing with the occurrence of $S$. bedoti in this ocean. There, this species was "found in fair abundance in both winter and spring (p. 213)". During the Deutsche Südpolar Expedition by the "Gauss" (RITTER-ZÁHONY,

\begin{tabular}{|c|c|c|c|c|c|c|}
\hline Java Sea & \multicolumn{2}{|c|}{ SiboGA 1906} & \multicolumn{2}{|c|}{ OYE 1918} & \multicolumn{2}{|c|}{ SNELLIUS 1941} \\
\hline $\begin{array}{l}\text { Number of } \\
\text { sampling stations }\end{array}$ & \multicolumn{2}{|c|}{10} & \multicolumn{2}{|c|}{77} & \multicolumn{2}{|c|}{24} \\
\hline * & 7 & \multirow{4}{*}{8} & - & \multirow{4}{*}{32} & 2 & \multirow{4}{*}{20} \\
\hline $1-5 \%$ & 1 & & 19 & & 11 & \\
\hline $6-10 \%$ & - & & 6 & & 2 & \\
\hline $11-15 \%$ & - & & 7 & & 5 & \\
\hline $16-20 \%$ & - & \multirow{4}{*}{0} & 4 & \multirow{4}{*}{8} & 1 & \multirow{4}{*}{1} \\
\hline $21-30 \%$ & - & & 3 & & - & \\
\hline $31-40 \%$ & - & & - & & - & \\
\hline $41-50 \%$ & - & & 1 & & - & \\
\hline Occurrence & \multicolumn{2}{|c|}{8} & \multicolumn{2}{|c|}{40} & \multicolumn{2}{|c|}{21} \\
\hline $\begin{array}{l}\text { Frequency of } \\
\text { Occurrence }\end{array}$ & \multicolumn{2}{|c|}{$80 \%$} & \multicolumn{2}{|c|}{$52 \%$} & \multicolumn{2}{|c|}{$88 \%$} \\
\hline $\begin{array}{c}\text { mean } \\
\text { Percentage }\end{array}$ & \multicolumn{2}{|c|}{+} & \multicolumn{2}{|c|}{$10 \%$} & \multicolumn{2}{|c|}{$6 \%$} \\
\hline
\end{tabular}

Table 47. Occurrence of $S$. bedoti in the Java Sea.

* present, but less than $1 \%$. 


\begin{tabular}{|c|c|c|c|c|}
\hline Celebes Ses & \multicolumn{2}{|c|}{ SIBOGA 1906} & \multicolumn{2}{|c|}{ SNELLIUS 1941} \\
\hline $\begin{array}{c}\text { Number of } \\
\text { sampling stations }\end{array}$ & \multicolumn{2}{|c|}{9} & \multicolumn{2}{|c|}{44} \\
\hline+ or $*$ & 4 & \multirow{4}{*}{7} & 1 & \multirow{4}{*}{29} \\
\hline $1-5 \%$ & 2 & & 19 & \\
\hline $6-10 \%$ & 1 & & 8 & \\
\hline $11-15 \%$ & - & & 1 & \\
\hline $16-20 \%$ & - & \multirow{3}{*}{0} & 2 & \multirow{3}{*}{4} \\
\hline $21-30 \%$ & - & & - & \\
\hline $31-40 \%$ & - & & 2 & \\
\hline Occurrence & \multicolumn{2}{|c|}{7} & \multicolumn{2}{|c|}{33} \\
\hline $\begin{array}{l}\text { Frequency of } \\
\text { Occurrence }\end{array}$ & \multicolumn{2}{|c|}{$78 \%$} & \multicolumn{2}{|c|}{$75 \%$} \\
\hline $\begin{array}{c}\text { mean } \\
\text { Percentage }\end{array}$ & \multicolumn{2}{|c|}{$3 \%$ (4 stations) } & \multicolumn{2}{|c|}{$7 \%$} \\
\hline
\end{tabular}

Table 48. Occurrence of $S$. bedoti in the Celebes Sea. * less than $1 \%$.

\begin{tabular}{|c|c|c|c|c|c|c|c|c|}
\hline \multirow[b]{2}{*}{49} & \multicolumn{4}{|c|}{ Banda Sea } & \multicolumn{4}{|c|}{ Moluccas Archipelago } \\
\hline & \multicolumn{2}{|c|}{ SIBOGA 1906} & \multicolumn{2}{|c|}{ SNELLIUS 1941} & \multicolumn{2}{|c|}{ SIBOGA 1906} & \multicolumn{2}{|c|}{ SNELIIUS 1941} \\
\hline $\begin{array}{c}\text { Number of } \\
\text { sampling stations }\end{array}$ & \multicolumn{2}{|c|}{15} & \multicolumn{2}{|c|}{68} & \multicolumn{2}{|c|}{23} & \multicolumn{2}{|c|}{53} \\
\hline+ or $*$ & 12 & \multirow{4}{*}{12} & 2 & \multirow{4}{*}{43} & 11 & \multirow{4}{*}{19} & 1 & \multirow{4}{*}{34} \\
\hline $1-5 \%$ & - & & 25 & & 3 & & 19 & \\
\hline $6-10 \%$ & - & & 12 & & 4 & & 10 & \\
\hline $11-15 \%$ & - & & 4 & & 1 & & 4 & \\
\hline $16-20 \%$ & 1 & \multirow{5}{*}{1} & 4 & \multirow{5}{*}{9} & - & \multirow{5}{*}{0} & - & \multirow{5}{*}{4} \\
\hline $21-30 \%$ & - & & 2 & & - & & 2 & \\
\hline $31-40 \%$ & - & & 3 & & - & & - & \\
\hline $41-50 \%$ & - & & - & & - & & 1 & \\
\hline $100 \%$ & - & & - & & - & & 1 & \\
\hline Occurrence & \multicolumn{2}{|c|}{13} & \multicolumn{2}{|c|}{52} & \multicolumn{2}{|c|}{19} & \multicolumn{2}{|c|}{38} \\
\hline $\begin{array}{c}\text { Frequency of } \\
\text { Occurrence }\end{array}$ & \multicolumn{2}{|c|}{$87 \%$} & \multicolumn{2}{|c|}{$76 \%$} & \multicolumn{2}{|c|}{$83 \%$} & \multicolumn{2}{|c|}{$72 \%$} \\
\hline $\begin{array}{c}\text { mean } \\
\text { Percentage }\end{array}$ & \multicolumn{2}{|c|}{+} & \multicolumn{2}{|c|}{$8 \%$} & \multicolumn{2}{|c|}{$7 \%$ ( 8 stations) } & \multicolumn{2}{|c|}{$7 \%$} \\
\hline
\end{tabular}

Table 49. Occurrence of $S$. bedoti in the Banda Sea and the Moluccas Archipelago. * less than $1 \%$. 


\begin{tabular}{|c|c|c|c|c|}
\hline Flores Sea & \multicolumn{2}{|c|}{ SIBOGA 1906} & \multicolumn{2}{|c|}{ SNELLIUS 1941} \\
\hline $\begin{array}{l}\text { Number of sampling } \\
\text { stations }\end{array}$ & \multicolumn{2}{|c|}{11} & \multicolumn{2}{|c|}{42} \\
\hline+ or $*$ & 6 & \multirow{4}{*}{6} & 2 & \multirow{4}{*}{27} \\
\hline $1-5 \%$ & - & & 10 & \\
\hline $6-10 \%$ & - & & 8 & \\
\hline $11-15 \%$ & - & & 7 & \\
\hline $16-20 \%$ & - & \multirow{2}{*}{0} & 1 & \multirow{2}{*}{2} \\
\hline $21-30 \%$ & - & & 1 & \\
\hline Occurrence & \multicolumn{2}{|c|}{6} & \multicolumn{2}{|c|}{29} \\
\hline Frequency of Occurrence & \multicolumn{2}{|c|}{$55 \%$} & \multicolumn{2}{|c|}{$69 \%$} \\
\hline Mean Percentage & \multicolumn{2}{|c|}{+} & \multicolumn{2}{|c|}{$8 \%$} \\
\hline
\end{tabular}

Table 50. Occurrence of $S$. bedoti in the Flores Sea. $*$ less than $1 \%$.

51 \begin{tabular}{c|c|c|}
\hline $\begin{array}{c}\text { Boni Bay in the } \\
\text { Flores Sea }\end{array}$ & SNELLIUS 1941 \\
\hline $\begin{array}{c}\text { Number of sampling } \\
\text { stations }\end{array}$ & \multicolumn{2}{|c|}{4} \\
\hline $1-5 \%$ & 1 & 2 \\
\hline $6-10 \%$ & 1 & 2 \\
\hline $11-15 \%$ & - & \\
\hline $16-20 \%$ & 1 & 2 \\
\hline $33 \%$ & 1 & 2 \\
\hline Occurrence & \multicolumn{2}{|c|}{4} \\
\hline Frequency of Occurrence & $100 \%$ \\
\hline Mean Percentage & \multicolumn{2}{|c|}{$16 \%$} \\
\hline
\end{tabular}

Table 51. Occurrence of $S$. bedoti in Boni Bay, the Flores Sea. 


\begin{tabular}{|c|c|c|c|c|c|c|c|}
\hline \multirow[b]{2}{*}{52} & \multicolumn{3}{|c|}{ Timor Sea } & \multicolumn{4}{|c|}{ Arafura Sea } \\
\hline & \multicolumn{2}{|c|}{ SNELLIUS 1941} & ТокIOKA 1956 & \multicolumn{2}{|c|}{ SNELLIUS 1941} & \multicolumn{2}{|c|}{ ToKIOKA 1956} \\
\hline $\begin{array}{l}\text { Number of } \\
\text { sampling stations }\end{array}$ & \multicolumn{2}{|c|}{12} & 6 & \multicolumn{2}{|c|}{18} & \multicolumn{2}{|c|}{49} \\
\hline $1-5 \%$ & 3 & \multirow{3}{*}{7} & \multirow{7}{*}{0} & 3 & \multirow{3}{*}{9} & 4 & \multirow{3}{*}{21} \\
\hline $6-10 \%$ & 3 & & & 5 & & 10 & \\
\hline $11-15 \%$ & 1 & & & 1 & & 7 & \\
\hline $16-20 \%$ & 1 & \multirow{4}{*}{2} & & 3 & \multirow{4}{*}{3} & 9 & \multirow{4}{*}{20} \\
\hline $21-30 \%$ & 1 & & & - & & 7 & \\
\hline $31-40 \%$ & - & & & - & & 1 & \\
\hline $41-50 \%$ & - & & & - & & 3 & \\
\hline Occurrence & \multicolumn{2}{|c|}{9} & 0 & \multicolumn{2}{|c|}{12} & \multicolumn{2}{|c|}{41} \\
\hline $\begin{array}{l}\text { Frequency of } \\
\text { Occurrence }\end{array}$ & \multicolumn{2}{|c|}{$75 \%$} & 0 & \multicolumn{2}{|c|}{$67 \%$} & \multicolumn{2}{|c|}{$84 \%$} \\
\hline Mean Percentage & \multicolumn{2}{|c|}{$9 \%$} & 0 & \multicolumn{2}{|c|}{$9 \%$} & \multicolumn{2}{|c|}{$17 \%$} \\
\hline
\end{tabular}

Table 52. Occurrence of S. bedoti in the Timor Sea and the Arafura Sea.

\begin{tabular}{|c|c|c|c|}
\hline Savu Sea & $\mathrm{SN}$ & 941 & SIBOGA 1906 \\
\hline $\begin{array}{c}\text { Number of sampling } \\
\text { stations }\end{array}$ & \multicolumn{2}{|c|}{20} & 1 \\
\hline $1-5 \%$ & 5 & \multirow{3}{*}{11} & \multirow{4}{*}{0} \\
\hline $6-10 \%$ & 3 & & \\
\hline $11-15 \%$ & 3 & & \\
\hline $16 \%$ & 1 & 1 & \\
\hline Occurrence & & & 0 \\
\hline Frequency of Occurrence & & & 0 \\
\hline Mean Percentage & & & 0 \\
\hline
\end{tabular}

Table 53. Occurrence of $S$. bedoti in the Savu Sea. 


\begin{tabular}{|c|c|c|c|c|c|}
\hline \multirow[b]{2}{*}{54} & \multicolumn{2}{|c|}{$\begin{array}{c}\text { Visakhapatnam } \\
\text { Oct. 1952 Apr. } 1953\end{array}$} & \multicolumn{3}{|c|}{$\begin{array}{c}\text { Centra plart of the Indian } \\
\text { Ocean }\end{array}$} \\
\hline & $\begin{array}{l}10 \sim 15 \text { miles } \\
\text { off shore }\end{array}$ & $\begin{array}{c}\text { more than } \\
20 \text { miles off shore }\end{array}$ & \multicolumn{3}{|c|}{ ToKIOKA 1956} \\
\hline $\begin{array}{l}\text { Number of } \\
\text { sampling stations }\end{array}$ & 13 & 21 & $\begin{array}{l}\text { Number of } \\
\text { sampling stations }\end{array}$ & \multicolumn{2}{|c|}{26} \\
\hline $1-5 \%$ & 1 & - & $1-5 \%$ & 2 & \multirow{3}{*}{12} \\
\hline $6-10 \%$ & - & - & $6-10 \%$ & 6 & \\
\hline $11-20 \%$ & - & 1 & $11-15 \%$ & 4 & \\
\hline $21-30 \%$ & 1 & - & $16-20 \%$ & 4 & \multirow{2}{*}{9} \\
\hline $33 \%$ & - & 1 & $21-30 \%$ & 5 & \\
\hline Occurrence & 2 & 2 & Occurrence & \multicolumn{2}{|c|}{21} \\
\hline $\begin{array}{l}\text { Frequency of } \\
\text { Occurrence }\end{array}$ & $15 \%$ & $10 \%$ & $\begin{array}{l}\text { Frequency of } \\
\text { Occurrence }\end{array}$ & \multicolumn{2}{|c|}{$81 \%$} \\
\hline Mean Percentage & $15 \%$ & $22 \%$ & Mean Percentage & \multicolumn{2}{|c|}{$15 \%$} \\
\hline
\end{tabular}

Table 54. Occurrence of $S$. bedoti in the Indian Ocean.

1911), S. bedoti was collected in the south-western part of the ocean from the surface water off Port Natal. On the opposite side in this ocean, it is reported from Sharks Bay on the western coast of Australia (RITter-ZÁHONy, 1910a). During the "Sea lark" Expedition in the western half of the Indian Ocean in 1905, S. bedoti occurred in only small numbers, the frequency of occurrence was also quite low, $12 \%$ (Burfield, 1926). GHIRARdelli (1948) reported that this sagitta occurred in the waters along the coast of Somaliland at a frequency of $34 \%$ (of 44 stations) and the number of specimens throughout the whole samples constituted $4 \%$ of the total chaetognaths.

In the Bombay Harbour, this sagitta is the commonest species and is found there throughout the year in considerably large numbers (LELE and GAE, 1936). On the eastern side of India, the species was not fonnd in coastal water of Madras (JoHN, 1933), but later its occurrence in this region was ascertained by SubRAMANyAM (1940). Satyanarayana Rao (1958) has recently shown that $S$. bedoti is as common as $S$. enflata throughout the year in Lawson's Bay, Waltair, East India. It is most abundant in January-February and June-July, but it diminishes in the offshore water and it is quite absent there in February and October. Further, SATYANARAyana Rao and GANAPATI (1958) discuss the occurrence of S. bedoti in the waters off Visakhapatnam Harbour south of Waltair as follows: the species is "very common in the inshore waters during most of the year; recorded rarely in the offshore waters, mostly surface dwelling (p. 150)". My examination (ТокіокA, 1956) of 26 plankton samples collected in the years 1954-1955 in the central part of the Indian Oean showed that this sagitta was one of the commonest species in this area. Also, I had an opportunity to examine three plankton samples from the north-eastern part of this ocean, near Nicobar, Nias and Bali-Lombok. In each of these samples, S. bedoti was found, 




Fig. 28. Distribution of Sagitta bedoti in the Indian Ocean. 
though only as 4,3 and 9 percent of the whole population respectively. S. bedoti was not found by Steinhaus (1896) in the southern part of the Indian Ocean nor was it found during the Gazelle Expedition (RITTER-ZÁHONY, 1909b). Gray (1923) also failed to find this species in samples taken in the southern Indian Ocean. In the Red Sea, S. bedoti was not found by either Pola (RITTer-ZÁhony, 1909a), Snellius, nor Cherso (GHIRARDELli, 1948).

i) The waters along the eastern coast of Australia.

Although both JOHNSTON and TAYLOR (1919) and TOKIOKA (1940b) could not find this sagitta in the southern part of this area, THOMSON (1947) found it in the southeastern waters of Australia and BURFIELD (1950) in the Great Barrier Reef region. In the south-eastern waters, it occurred at 25 stations, this constitutes $9.1 \%$ of all sampling stations. According to Fig. 4 in THOMSON's paper, it was "infrequent" in the area northward to $28^{\circ} \mathrm{S}$, but "rare" in the area between $28^{\circ} \mathrm{S}$ to $35^{\circ} \mathrm{S}$. The frequency of occurrence was $8.8 \%$ in the oceanic zone, while it was $9.2 \%$ in the neritic zone. ' In the Great Barrier Reef region, it occurred inside the reef at $25 \%$ of 48 stations and the number of specimens throughout the whole collection was $3.4 \%$ of the total chaetognaths, while outside the reef the frequency of occurrence was $23 \%$ of 13 stations, and the percentage of specimens of this sagitta to the total chaetognaths was about $0.3 \%$. Thus, Burfield states as follows :- "When present, this was fairly abundant inside the reef, but was very scarce outside. This is considered to be warm water form of the Indian and Pacific Oceans, and found from the surface to $50 \mathrm{~m}$ ".

j) The far oceanic waters of the Pacific, excluding the coastal waters along the continents, the Japanese and Philippine Islands and the Malay Archipelagoes (Table 55).

During examination of a lot of plankton samples collected in the waters around the Palao Islands of the western Caroline Islands in 1940, I found S. bedoti in the material, but in only very small numbers. It appears to be distributed in the counter Equatorial Current, the South Equatorial Current, and the New Guinea Coastal Current, but rarely found in the North Equatorial Current and in the waters around the Palao Islands. In lagoons of the Palao Islands, this species was not found during my observation for eight months (1940-41). Later, I examined two other collections of chaetognaths from the equatorial region of the Pacific; a small series collected in 1953 near the Phoenix and the Gilbert Islands in the central Pacific, and the material collected in 1954 by the "Syunkotu-Maru" during her cruise to survey the after effects of a series of experiments with atomic and hydrogen bombs at Bikini Atoll. In both cases, I could not find any S. bedoti. RoSE (1952) examined plankton samples from lagoons of the Tuamotu Islands, but found no S. bedoti. Both HIDA's paper (1957) based on the material collected by the Pacific Oceanic Fishery Investigations of Hawaii in the middle North Pacific and BIERI's comprehensive report (1959) 


\begin{tabular}{|c|c|c|c|c|c|c|c|}
\hline $\begin{array}{l}\text { Near the Western } \\
\text { Caroline Islands }\end{array}$ & $\begin{array}{l}\text { Around the } \\
\text { Palao Islands }\end{array}$ & $\begin{array}{l}\text { Nor } \\
\text { toria }\end{array}$ & $\begin{array}{l}\text { ua- } \\
\text { rent }\end{array}$ & $\begin{array}{l}\text { Cou } \\
\text { tori }\end{array}$ & $\begin{array}{l}\text { qua- } \\
\text { rent }\end{array}$ & $\begin{array}{l}\text { So } \\
\text { tori }\end{array}$ & $\begin{array}{l}\text { Iua- } \\
\text { rent }\end{array}$ \\
\hline $\begin{array}{l}\text { Number of } \\
\text { sampling stations }\end{array}$ & 22 & \multicolumn{2}{|c|}{24} & \multicolumn{2}{|c|}{19} & \multicolumn{2}{|c|}{16} \\
\hline * $1-5 \%$ & \multirow{6}{*}{ no data } & - & \multirow{3}{*}{0} & 1 & \multirow{3}{*}{7} & 2 & \multirow{3}{*}{9} \\
\hline * $6-10 \%$ & & - & & 4 & & 1 & \\
\hline$* 11-15 \%$ & & - & & 2 & & 6 & \\
\hline$* 16-20 \%$ & & - & & - & & 1 & \\
\hline$* 21-30 \%$ & & - & 0 & 1 & 2 & - & 2 \\
\hline * $31-32 \%$ & & - & & 1 & & 1 & \\
\hline Occurrence & 2 & & & & & & \\
\hline $\begin{array}{l}\text { Frequency of } \\
\text { Occurrence }\end{array}$ & $9 \%$ & & & & & & \\
\hline * mean Percentage & + & & & & & & \\
\hline
\end{tabular}

* Data obtained from the examination of 31 plankton samples hauled during the Oceanographic surveys of Palao New Guinea in March - May 1940.

Table 55. Occurrence of $S$. bedoti in the material of Palao $\sim$ New Guinea cruises.

based on the material from the Equapac and the Troll Expeditions and also other collections show that $S$. bedoti does not occur in the vast central area of the northern half of the Pacific.

k) The Atlantic Ocean.

The only record of $S$. bedoti from the Atlantic is presented by THIEL (1938) who recorded that only a single specimen of $S$. bedoti was found at Station 20 (50 $100 \mathrm{~m}$ ) near Cape Town during the German Meteor Expedition in the Atlantic Ocean. It is possible that S. bedoti might be carried into the Atlantic Ocean from the Indian Ocean by the southward Mozambique Current and then westward by the Agulhas Current along the southern coast of Africa, because this sagitta occurs near Port Natal as mentioned in section (h). This is very probable, because S. neglecta and $S$. regularis, both typical Indopacific warm water species, are also found in the Benguela Current off the west coast of the Union of South Africa, being carried there by the Agulhas Current (Heydorn, 1959).

\section{The identity of $S$. bedoti from various localities.}

One can be somewhat skeptical about the record of $S$. bedoti from the Atlantic Ocean, because it is not impossible that an imperfectly preserved immature specimen of $S$. friderici might be mistaken for S. bedoti. In some cases, the distinction between these two species can be made only on the presence (bedoti) or absence (friderici) of the rayless zones on the lateral fins. This character becomes easily obscured in some poorly preserved specimens.

Next, are the specimens of $S$. bedoti occurring in the eastern Pacific along the 
western coast of the equatorial Central and South Americas identical with those from the waters around the Philippines and Malay Archipelagoes? Examining closely the specimens from the eastern Pacific, I could affirm that they were quite identical with the so-called forma minor of $S$. bedoti found abundantly in the waters of the western tropical Pacific, as already shown in the section on taxonomic descriptions.

Lastly, are the specimens of $S$. bedoti from the Japanese waters identical with those found in the southern seas? For instance, THOMSON (1947) states that my records of Sagitia bedoti from the waters around Korea in 1940 might be erroneous, because they are much larger than those found in the southern seas. However, I believe they are truly bedoti. All characteristics, except for the body length, are quite common to specimens from both Japanese waters and the southern seas. The difference in body length is somewhat remarkable ( $30 \mathrm{~mm}$ to about $15 \mathrm{~mm}$ ), but we find many other examples of such remarkable difference in body length. For instance, Sagitta robusta matures at $10 \mathrm{~mm}$ in the southern seas, but it reaches $21 \mathrm{~mm}$ in the water of somewhat low temperature in the Japan Sea; S. enflata is usually $15 \mathrm{~mm}$ or thereabout when mature, but it may attain $30 \mathrm{~mm}$ in the waters off Peru. Moreover, $S$. bedoti of the East China Sea and the Yellow Sea and that of the waters around the Malay Archipelagoes can be intermixed by the southward current in winter and the northward flow in summer through the South China Sea, although the strong influx of the North Equatorial Current seems to lower the density of this sagitta in this sea and lessen intermixing on a large scale. As far as concern the specimens examined by myself, there is not any doubt, I believe, that only a single species $S$. bedoti is here under consideration at present. .

\section{General account of the distribution of $S$. bedoti.}

My acquaintance with $S$. bedoti gained through studies carried on at the Mitui Institute of Marine Biology near Simoda, Izu (1938), the observations made in the eastern part of the Inland Sea, namely Ôsaka Bay and Kii-Channel (1939), and the examination of the chaetognaths material from the waters arounnd western Japan (1940), and also through references accessible for me by that time, led me to believe that $S$. bedoti should be one of the common warm oceanic water species, probably being distributed in the Pacific as widely as many other warm water species. Hence, it appeared very strange to find that this sagitta was quite rare in the waters around the Palao Islands of the western Caroline Islands, when I examined, in 1940, a lot of planktsn samples hauled in this area. However, when I had finished the examination of chaetognaths collected from the central equatorial Pacific, extending from the Gilbert and Phoenix Islands to the Marshall Islands, I was aware of the possibility that the scantiness of $S$. bedoti in far oceanic water of the Pacific was not a temporal phenomenon but it is a distinct general feature. Consequently, I paid attention to the currents flowing in the western North Pacific and in the equatorial region, especially to the relation between the surface waters of the North Equatorial Current 
and the Kurosio. The Pacific coast of Japan is said to be washed by the Kurosio. Therefore, if the greater part of the surface water of the Kurosio were purely an extension of the North Equatorial Current, then S. bedoti would not appear abundantly along the Pacific coast of Japan. Furthermore, the contamination of the sea water by the fission products emitted by experiments at Bikini would be observed near the coast more frequently and in higher degree than it actually was. Of course, there could be water masses of somewhat coastal character along some parts of the Pacific coast of Japan and they may maintain S. bedoti and lessen the direct effect of the Kurosio. Moreover, there should be the lateral mixing of water along the left (west) side of the Kurosio, between it and the coastal water along the continent. This mixing might be carried on to a much larger scale than has been supposed. It is possible that $S$. bedoti may here be available as an indicator of the degree of this mixing in some parts of the Kurosio. To clear up these points, I started to collect data regarding the occurrence of $S$. bedoti, and to outline preliminarily the distribution of this species (ТокіокA, 1957) from the plankton material collected by the Sôyo-Maru over a wide area extending from the northern Japan to the South China Sea. Now, with BIERI's comprehensive report (1959) on the distribution of chaetognaths in the Pacific together with personal observations on the large plankton collections present at Scripps Institution of Oceanography and with data from various other papers and personal communications all indicating an absence of $S$. bedoti in the mid Pacific, I believe the general features of the species can be discussed. Of course, the distribution will differ somewhat according to seasons. The differences are especially remarkable in the Indian Ocean and in some parts of the western Pacific, where the direction of currents may be quite changed with seasons. It is important to know if sampling stations and times were distributed evenly in a certain area, or to know whether or not this sagitta shows some peculiar vertical distribution. Concerning the latter point, so far as I am aware, this species can be considered an inhabitant of the surface water, probably above $100 \mathrm{~m}$, most abundantly above $50 \mathrm{~m}$. As to the seasonal variation in distribution and the even distribution of sampling stations and sampling times, I do not believe the data at hand are sufficient, but still I think they are sufficient to show the general outline of the distribution.

Sagitta bedoti is distributad widely in the Indian Ocean excluding the southern part of the ocean. In general, it is not abundant there, usually less than $10 \%$ of all chaetognaths, although it occurs commonly and abundantly in some embayments such as Bombay Harbour on the western coast and Lawson's Bay on the eastern coast of India. It occurs widely in the waters around the Malay Archipelagoes, but there also its percentage of the chaetognath fauna is usually less than 10\%, excepting some cases in Boni Bay in the Flores Sea and in the Arafura Sea in some seasons. Most probably in the Indian Ocean and the waters around the Malay Archipelagoes, $S$. bedoti propagates in certain embayments or bays, out of which it drifts and is distributed widely in the ocean by the remarkable water movements found in these 
seas. As the currents vary remarkably in the Indian Ocean and around the Malay Archipelagoes depending upon season, the abundance of $S$. bedoti in these areas also fluctuates much according to season. At times waters-masses of somewhat coastal character and containing many S. bedoti may drift out into the central part of the Indian Ocean and give rise to the records of higher percentages in the middle of the ocean. The population of this species in the Arafura Sea is continuous with that along the eastern coast of Australia. Since there is no report indicating dense population of the species in the coastal waters of the eastern Australia, the population of this sagitta in certain portion of this area seems to be supplied in part from the Arafura Sea at least in the season when the currents in the Arafura Sea flow towards the east.

$S$. bedoti occurs in the South China Sea and in Philippine waters, but only infrequently and in very small numbers; for instance, in the Philippine waters it is recorded only from the Sulu Sea. Possibly this is due to the effect of the strong influx of the North Equatorial Current which is quite devoid of this sagitta. The species increases towards the north along the continent and attains a remarkably dense population (nearly 100\% of all chaetognaths and also at a frequency of $100 \%$ in all plankton hauls) in the coastal part of the East China Sea and in the southern part of the Yellow Sea. It is usually absent in the south-eastern part of the East China Sea near Okinawa, where the northward extension of the North Equatorial Current flows. However, it appears in the north-eastern part of the sea, where the water of the East China Sea is conducted out by the strong flow of the Kurosio, and reaches a considerable density near the southern end of Kyûsyû Island. Its population near the southern end of Kyûsyu seems to fluctuate rather violently according to season and also according to hydrographical conditions changing from time to time. This species increases steadily in numbers from the western coast of Kyûsyu to the Korea Straits, where the waters of the East China Sea and the Yellow Sea are mixed in a considerable degree with the water of a branch of Kurosio, Tusima Current. In the Japan Sea it may constitute $100 \%$ of the chaetognath fauna at some stations along the boundary between the Liman and Tusima Currents. It also increases steadily in numbers along the Pacific coast of Honsyû, the mainland of Japan, and attains its maximum in the waters off the north-eastern part of Honsyu along the boundary between the Oyasio and the Kurosio. The distribution may extend eastwards to $161^{\circ} 39^{\prime} \mathrm{E}$; then it disappears completely in the vast area of the Pacific. Along the Pacific coast of Honsyô Island, this sagitta occurs commonly in the water mass on the coastal side of the Kurosio, but diminishes remarkably in the main stream of the Kurosio and disappears in the far oceanic water mass beyond the Kurosio. There, the Kurosio seems to constitute a barrier between the Japanese coastal water mass which is evidently populated by various organisms from the East China Sea, and the far oceanic water.

The species occurs in an isolated small area at the eastern-most part of the equatorial Pacific. It is quite absent in the North Equatorial Current, the Counter 
Equatorial Current, and the South Equatorial Current along their long course to the western Caroline Islands, where it appears again in insignificant numbers in the North Equatoriol Current and increases in numbers towards the south. Probably S. bedoti is derived from the Sulu or Celebes Seas and carried eastward by the Mindanao Current and the Counter Equatorial Current. At first, I thought it possible that the population at the eastern-most part of the equatorial Pacific might be continuous with that in the south-eastern waters of Australia through the eastward current in the southern part of the South Pacific, but this is unlikely, because this sagitta decreases sharply at the southern stations in the Shellback area, quite disappears in the waters off Chile and at the offshore stations in the south-eastern waters of Australia.

\section{Possible factors limiting the distribution of S. bedoti.}

At a glance, $S$. bedoti might be considered as an inlet or bay-form since it occurs abundantly in Bombay Harbour and Lawson's Bay of India and in Boni Bay in the Flores Sea. However, there is a genuine inlet-water chaetognath in the Indian waters, namely Sagitta bombayensis. Also in the Japanese waters, the inlet-waters are populated by S. crassa, its forma naikaiensis and Sagitta delicata. S. bedoti is absent in the waters where these species are dominant. Along the Californian coast, the inlet-waters or lagoons are populated by S. tenuis. Thus, S. bedoti cannot be considered as an inlet-water form. Can it then be a coastal-water form? However the occurrence of the species in abundance in the central part of the Indian Ocean and in the far offshore waters along the boundary between the cold Oyasio and the the warm Kurosio in the western North Pacific, conflicts with this idea. Novertheless, it is an obvious fact that this species is distributed along the coasts in very many places of the Indo-Pacific. The ranges of temperature and salinity in the areas where $S$. bedoti occurs are surprisingly wide. For instance, Satyanarayana Rao and GANAPATI give $26.6-29.5^{\circ} \mathrm{C}$ for temperature and $20.79-34.16 \%$ for salinity in the Indian waters; SUND (1959c) gives $9-27^{\circ} \mathrm{C}$ for temperature and $27.9-34.8 \%$ for salinity in the upper 300 meters at all stations inspected where this species occurred during the Eastropic Expedition; the lowest salinity in my data is 30.95\% in the surface and $31.89 \%$ in the deeper layer in the Korea Straits and the lowest temperature is $11.5^{\circ} \mathrm{C}$ in the Yellow Sea. Thus, it is evident that $S$. bedoti is euryhaline and eurythermal and this seems to support the idea that it is a coastal-water form or a form which is fond of the mixed water. As to the latter point, actually most of the coastal waters where $S$. bedoti occurs in high numbers are found near areas of mixing or the boundaries between different waters. In the Yellow Sea and the East China Sea, the far oceanic water of the western North Pacific and the coastal water of somewhat lower salinity are mixed. In the Japan Sea, the cold Liman Current and the warm Tusima Current mingle with each other. Off the NorthEastern part of Honsyu Island of Japan, the cold Oyasio and the warm Kurosio waters mix. In the eastern part of the equatorial Pacific, some upwelled water and the cold 
Humboldt Current mingle with the tropical warm surface water. However, the biological conditions found in the mixing areas of different waters are favourable not only for $S$. bedoti but also for many other chaetognaths under certain circumstances; for instance in the Shellback area in the eastern equatorial Pacific many species of Sagitta thrive. On the other hand, in the central part of the Indian Ocean, where no remarkable mixing of different waters can be seen, a comparatively dense population of $S$. bedoti is maintained at least in some seasons. Why the same chaetognath which occurs in the central part of the Indian Ocean cannot survive in the mid Pacific Ocean is a moot question. The temperature-salinity relationships seem to be insufficient to explain the facts regarding this eurythermal and euryhaline chaetognath. Are there then some special chemical or biological factors (through food organisms, predators or competition) which differ between the Indian Ocean and the Pacific? So far as I am aware, there has not been as yet any definite answers to this question.

\section{VII. "Bedoti-water".}

Then, the following idea is considered possible that $S$. bedoti has specialized from a certain ancestor in the water mass which to-day contains this species in a considerable density and that the mixing of the water between this water mass and other water masses has been carried on in such a scale that the density of $S$, bedoti in the latter, dispersed there from the former, is always maintained below the lowest population level at which this sagitta can propagate. S. bedoti, when dispersed into far oceanic water might survive, but might be unable to reproduce below a certain population level, because self-fertilization is impossible. The lowest density at which the reproduction of the species can be maintained should differ specifically and it is conceivable that this limiting density might be comparatively high for $S$. bedoti. In other words, a comparatively high degree of stability can be expected in water masses containing S. bedoti in considerable numbers. In the East China Sea, the Yellow Sea and the middle part of the Japan Sea, the water is evidently moving, but it is considered to be circulating in a semi-closed system and thus considerable stability is maintained there. As regards propagation of various plankton organisms in areas of mixing, it is evident that a certain degree of stability of the mixed water is required for reproduction. Thus, it seems reasonable to separate the water masses containing $S$. bedoti from far oceanic water masses free from this species. It is proposed here to call the former "bedoti-water" because of this characteristic indicator. In the eastern Pacific, S. friderici shows a distribution somewhat like that of S. bedoti and actually occurs in the Shellback area together with S. bedoti. Besides these, S. neodecipiens and a peculiar form of $S$. ferox (f. americana) occur solely in this eastern bedoti-water. In the western North Pacific, the distribution of a calanoid copepod Calanus lighti is limited to far oceanic water and does not occur in the bedoti-water, some of the euphausids distributed widely in the western North Pacific seem to be 
slightly differentiated in some parts of the bedoti-water, the Japan Sea or in the East China Sea. All these facts seem to be attributable to the stability of the bedoti-water.

It might be possible to judge the grade of segregation of water-masses containing $S$. bedoti from the far oceanic water mass free from $S$. bedoti by measuring the density of this chaetognath. For instance, in the South China Sea, the low population of $S$. bedoti indicates a strong influx of the North Equatorial Current; near the southern coast of Kyûsyâ, the Pacific coast of Honsya and also in the Japan Sea the population of this species fluctuates considerably, probably according to the relative amount of influx of far oceanic water. In the Japan Sea, the average percentage of S. bedoti differs remarkably according to season, namely $30 \%$ in April, $16 \%$ in July and only $5 \%$ in September (1951-53). These data agree completely with the variation in strength of the Tusima Current and consequently the extent of far oceanic water.

As to the dense population of this chaetognath in the area of mixing between the Oyasio and the Kurosio off the north-eastern part of Honsyû of Japan, the distribution in this area cannot be considered as allogenetic one, but rather autogenetic distribution, because there occur very many young individuals (12 to $74 \%, 49 \%$ on an average in examined samples) referable to $S$. bedoti, and moreover it frequently constitutes $100 \%$ of the whole chaetognath population. Thus, the water in this area is considered to show a considerable degree of stability. I cannot judge whether this stability is attributable simply to the effect of ScHRöDER's law applicable along the northern border of the Kurosio flowing eastwards or maintained by complex horizontal or vertical circulations; the questions will be answered by further works by hydrographers. At present, it is also unknown where the eastern distal end of this bedotiwater goes. It might extend towards the north east, where it is cooled below the critical temperature for $S$. bedoti, or it might be dispersed in the western North Pacific Central Water Mass below the limiting density required for propagation of this species. The wide distribution of $S$. bedoti in the Indian Ocean might be attributable partly to the smallness of this ocean itself or the existence of complex currents in this ocean.

\section{THE FAR OCEANIC WATER OF THE CENTRAL NORTH PACIFIC}

The remaining vast far oceanic water mass of the Pacific is divided into northern and southern halves by the Equatorial Currents. As to the possible differences in chaetognath fauna between these two halves and between the Western North Central Pacific and the Eastern North Central Pacific Water Masses, my data are less extensive than those of BIERI (1959), hence I shall not repeat any comments on this problem. However, I think it is useful to record here only the proportions between the four most commonly occurring species, mentioned below, in far oceanic waters and speculate as to the possibility of any constant differences in the chaetognath fauna between the above-mentioned divisions of the far oceanic waters. BIERI (1959) showed only the distribution of individual per unit volume of water for respective 
species in the Pacific. The various collections I have dealt with in this paper were collected by various kinds of gears and it is certain that even the same gear might not be used always in quite the same manner. However, the ratios among certain dominant species seem to be rather stable, because the effect of different gears and the manner in which they were used is minimized by this procedure. The errors which inevitably occur during the course of computing the individuals per unit volume of water might also be much reduced in this representation.

In Table 56, it is seen clearly that $S$. enfiata $a$ is the commonest of the species collected in the warm oceanic waters of the North Pacific, next in order is S. serratodentata pacifica, $P$. draco, and $S$. hexaptera, as I previously noted on material from the waters around the Marshall Islands (1955). In the material of the Transpac Expedition, S. minima (F. O.*-39\%, average percentage -30 ) and $S$. regularis (F. O.-26\%, average percentage-9) were the important species; and in the Shellback material, S. serratodentata tasmanica (F. O.-98\%, average percentage-8) occurred commonly and followed by $K$. subtilis, K. pacifica, S. minima, S. regularis, S. lyra and S. decipiens. Therefore, I calculated the three ratios S. serratodentata pacifica/S. enflata (S/E), S. hexaptera/S. enflata (H/E) and P.draco/S. enflata (P/E); and plotted the values of $\mathrm{S} / \mathrm{E}$ in Figs. 29-31.

Before deducing any tendencies from the figures and tables, it is necessary to consider whether or not the greater part of the population of each of the abovementioned four dominant species occurs in the surface water above $50 \mathrm{~m}$. If it does not and if some of these species occur very abundantly in layers deeper than $50 \mathrm{~m}$ under some conditions or in some regions, then the comparison of ratios throughout the whole materials consisting of samples collected from various depths would be quite meaningless. Very fortunately, however, the dominant species, here selected, and also most of the common species in the warm water are concentrated in the upper $50 \mathrm{~m}$ layer, as mentioned by THIEL (1938) in the report of the German Atlantic Expedition by the "Meteor". HIDA (1957) mentions that "On Hugh M. Smith cruise 30 large catches, as number per unit of water strained, of Chaetognaths and Pteropods were taken in the shallow $(0-40 \mathrm{~m})$ hauls than in the deeper $(0-140 \mathrm{~m})$ hauls both during the day and at night". The tendency of chaetognaths to concentrate in the upper water seems to be as true in the Pacific as in the Atlantic. Hence, a comparison of ratios on world wide collections seems to be significant in a search for trends, although the values themselves in different samples collected from different depths cannot be estimated strictly on the same level. This point will be most pronounced in the case of $P$. draco, if this species is distributed in the Pacific in the same manner as in the Atlantic, where the centre of the distribution of this species is moved to the layer slightly deeper than in other three species.

The ratios calculated on the material from the Transpac Expedition, in which a small net $(17 \mathrm{~cm}$ in diameter) was used and the catches were very small, fluctuate

* F. O....Frequency of Occurrence 
Taxonomy and Distribution of Chaetognaths

\begin{tabular}{|c|c|c|c|c|c|c|}
\hline 56 & T P & $\mathbf{J}$ & MP & S B & EQP & $\mathrm{P}-\mathrm{N}$ \\
\hline Sag. hexaptera & 80 & - & 748 & 588 & 1300 & 70 \\
\hline Sag. lyra & $\dot{4}$ & - & - & 146 & - & - \\
\hline Sag. enflata & 644 & 828 & 1944 & $\mathbf{3 3 0 0}$ & 4000 & 3395 \\
\hline Sg. bipunctata & 299 & 65 & 19 & 25 & 200 & - \\
\hline Sag. ferox & 18 & 117 & 8 & - & 60 & 264 \\
\hline Sag. ferox f. americana & - & - & - & 186 & - & - \\
\hline Sag. robusta & 75 & - & 63 & 48 & 100 & - \\
\hline Sag. bedoti & 204 & 1008 & - & 224 & - & 897 \\
\hline Sag. pulchra & - & - & $*$ & 78 & 40 & 49 \\
\hline Sag. friderici & 16 & - & - & 50 & - & - \\
\hline Sag. pacifica & 2738 & 693 & 2520 & 2200 & 1700 & 1720 \\
\hline Sag. tasmanica & 1 & - & 一 & 784 & - & 一 \\
\hline Sag. pseudoserratodentata & 45 & - & 112 & 34 & 20 & 一 \\
\hline Sag. neglecta & 12 & 39 & 24 & 42 & $*$ & 416 \\
\hline Sag. oceania & - & - & - & - & 20 & - \\
\hline Sag. regularis & 279 & 1035 & 14 & 134 & 200 & 1806 \\
\hline Sag. bedfordii & - & - & - & - & - & 20 \\
\hline Sag. crassa f. naikaiensis & 18 & 104 & - & 一 & - & - \\
\hline Sag. minima & 1200 & 1587 & 154 & 192 & $*$ & - \\
\hline Sag. decipiens & $*$ & - & - & 65 & 200 & - \\
\hline Sag. neodecipiens & - & - & - & 23 & - & - \\
\hline Sag. planctonis & - & - & $*$ & $*$ & - & - \\
\hline Sag. macrocephala & - & - & 6 & - & - & - \\
\hline Pterosag. draco & 600 & - & 1470 & 864 & 1700 & 869 \\
\hline Ktta. subtilis & 28 & - & 105 & 276 & 80 & 3 \\
\hline Ktta. pacifica & 217 & - & 11 & 162 & 80 & 240 \\
\hline Eukr. hamata & - & - & 8 & $*$ & - & - \\
\hline Damaged specimens or juv. & 3420 & 4576 & 2047 & 600 & 900 & 264 \\
\hline
\end{tabular}

Table 56. Occurrence of warm water species in respective materials (samples from inlet waters excluded).

Numbers indicate the value Frequency of Occurrence $\times$ mean percentage in

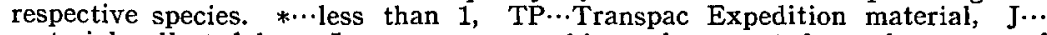
material collected by a Japanese survey ship and presented to the party of the Transpac Expedition, MP...Midpac Expedition material, SB...Shellback Expedition material, EQP...Equapac Expedition material, $\mathrm{P}-\mathrm{N} \cdots$ Material of the Palao - New Guinea cruises. 


\begin{tabular}{|c|c|c|c|c|}
\hline 57 & S. enflata & S. hexaptera & S. serratodentata & Pterosag. draco \\
\hline $0-50 \mathrm{~m}$ & 26.8 & 5.6 & 42.6 & 4.57 \\
\hline $50-100 \mathrm{~m}$ & 7.2 & 4.68 & 12.94 & 7.0 \\
\hline $100-200 \mathrm{~m}$ & 1.05 & 1.36 & 4.0 & 1.4 \\
\hline $200-400 \mathrm{~m}$ & 0.75 & 0.2 & 1.2 & 0.2 \\
\hline $400-600 \mathrm{~m}$ & & 0.02 & 0.08 & 0.05 \\
\hline $600-800 \mathrm{~m}$ & & & 0.07 & 0.01 \\
\hline $800-1000 \mathrm{~m}$ & & & 0.06 & \\
\hline
\end{tabular}

Table 57. Vertical distribution of four important species in the Atlantic (THIEL, 1938).

rather violently, and consequently a comparison between these ratios and those of other catches collected by large nets from deeper waters is less significant. Here also, the efforts must be limited to seeking out trends. Throughout Figs. 29-31 and Tables 58-68, 70 and 73 the most remarkable trend may be noted in the distribution of the ratio between $S$. serratodentata pacifica and $S$. enflata (S/E).

a) Distribution of $\mathbf{S} / \mathbf{E}$ in collections examined (Figs. 29-31, Tables 58-60).

The distribution of $\mathrm{S} / \mathrm{E}$ shows a distinct tendency towards lower values in watc. masses inhabited by $S$. bedoti and higher in the bedoti free water masses. Generally speaking, in samples containing $S$. bedoti the values of $\mathrm{S} / \mathrm{E}$ higher than 1.00 occur less frequently than the values lower than 1.00 , while in samples containing no $S$. bedoti the values higher than 1.00 occur more frequently than the values lower than 1.00 . The latter trend is, however, rather obscured in the Equapac Expedition material, the collection during the Palao-New Guinea cruises, and also in collections from the area within the distributional range of $S$. bedoti, such as the waters off north-eastern part of Japan and the Shellback area. Further, Fig. 29 shows that S/E is lower than 1.00 at-most stations along the equatorial zone in the central Pacific, south of approximately $10^{\circ} \mathrm{N}$. In other words, S. enflata is more abundant than S. serratodentata pacifica in the bedoti-water and also in the equatorial water mass in the far oceanic area of the Pacific, but decreases conspicuously and becomes less abundant than the latter in other parts of the far oceanic water of the Central North Pacific. The scarcity of $S$. enflata is epecially marked in the eastern half of the Central North Pacific, east of $180^{\circ}$, and most pronounced in the north eastern quarter of the Central North Pacific shown in Fig. 29, where S. enflata is nearly absent. Even S. serratodentata pacifica diminishes prominently there and the greater part of the chaetognath fauna consists of S. minima. HIDA's paper (1957) on the chaetognath fauna in the central North Pacific also shows distinctly the scarcity of $S$. enflata throughout the subtropic and the transition zones extending from $145^{\circ} \mathrm{W}$ to $170^{\circ} \mathrm{E}$. The boundary 




Fig. 30. Distribution of $\mathrm{S} / \mathrm{E}$ in the Japanese and adjacent waters. 


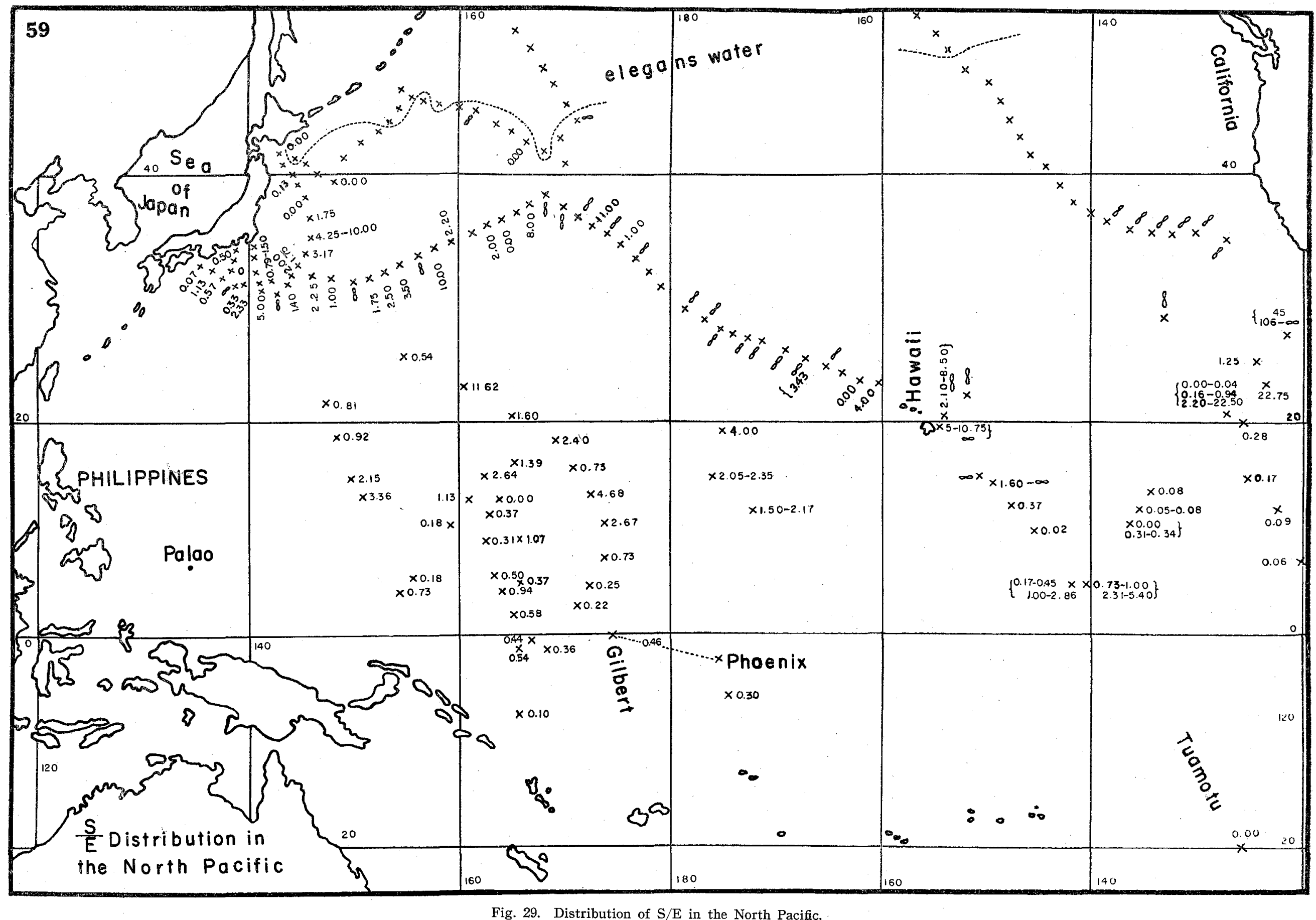




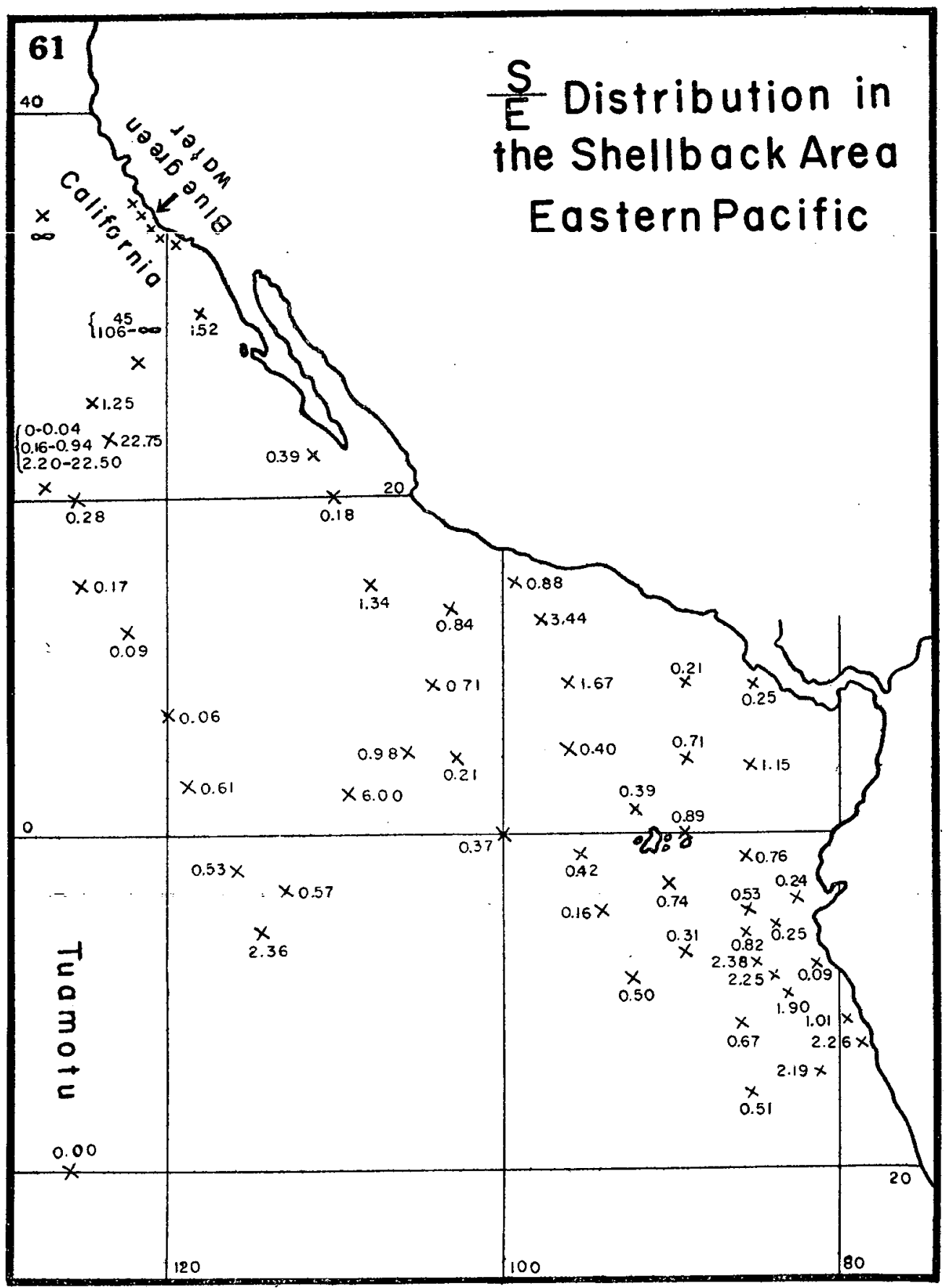

Fig. 31 Distribution of $\mathrm{S} / \mathrm{E}$ in the Shellback area. 


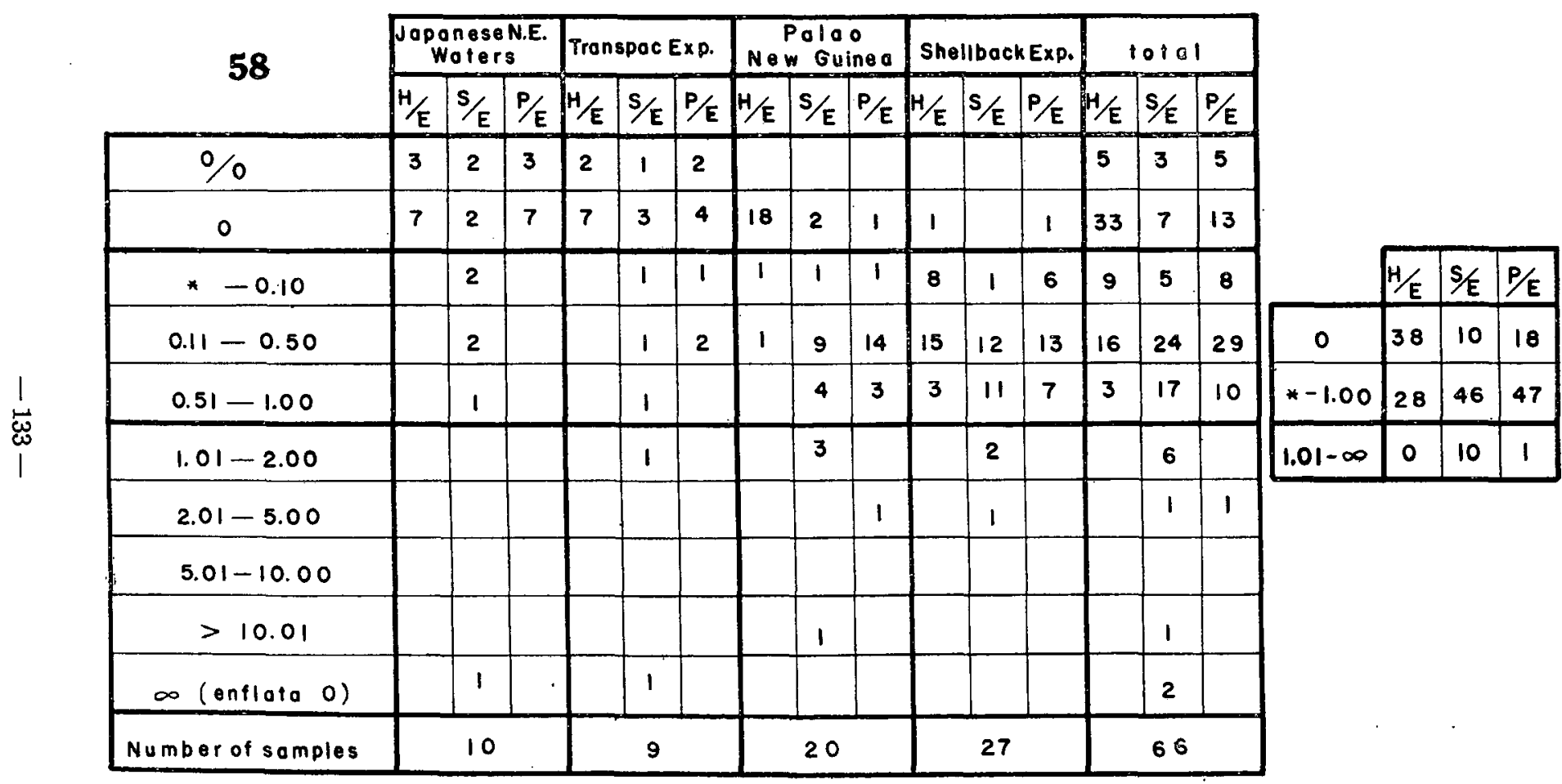

Table 58. Occurrence of respective values of $H / E, S / E$ and $P / E$ in samples collected

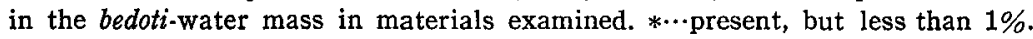




\begin{tabular}{|c|c|c|c|c|c|c|c|c|c|}
\hline \multirow{2}{*}{59} & \multicolumn{3}{|c|}{$\begin{array}{l}\text { Transpac Exp. incl } \\
\text { IStrangert somp. }\end{array}$} & \multicolumn{3}{|c|}{ Midpoc Exp. } & \multicolumn{3}{|c|}{ Shellbock Exp. } \\
\hline & $H / E$ & $s / E$ & $P / E$ & $H / E$ & $s / E$ & $P / E$ & $H / E$ & $S / E$ & $P / E$ \\
\hline $0 / 0$ & 15 & 7 & 14 & 6 & 6 & 6 & & & \\
\hline 0 & & & & 11 & 2 & 10 & & & 1 \\
\hline$*-0.10$ & & & & $s$ & 5 & 3 & 9 & 2 & 6 \\
\hline $0.11-0.50$ & & & & 11 & 6 & 7 & 8 & 4 & 12 \\
\hline $0.51-1.00$ & & & & 3 & 5 & 5 & 2 & 4 & 1 \\
\hline $1.01-2.00$ & & & & 5 & 3 & 5 & 2 & 4 & 1 \\
\hline $2.01-5.00$ & & & & 4 & 11 & 7 & & 5 & \\
\hline $5.01-10.00$ & & & & 1 & 3 & 2 & & 1 & \\
\hline$>10.01$ & & & & & 5 & 2 & & 1 & \\
\hline$\infty($ enflata 0$)$ & 1 & 9 & 2 & 4 & 5 & 4 & & & \\
\hline Number of somples & & 16 & & & 51 & & & 21 & \\
\hline
\end{tabular}

\begin{tabular}{|c|c|c|c|c|c|c|c|c|c|}
\hline 0 & 15 & 7 & 14 & 17 & 8 & 16 & & & 1 \\
\hline$*-1.00$ & & & & 20 & 16 & 15 & 19 & 10 & 19 \\
\hline $1.01-\infty$ & 1 & 9 & 2 & 14 & 27 & 20 & 2 & 11 & 1 \\
\hline
\end{tabular}

Table 59. Occurrence of respective values of $\mathrm{H} / \mathrm{E}, \mathrm{S} / \mathrm{E}$ and $\mathrm{P} / \mathrm{E}$ in samples collected in the bedoti-free water mass in the eastern half of the North Pacific in materials

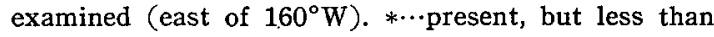
$1 \%$.

between the bedoti-water and the far oceanic water showing higher $\mathrm{S} / \mathrm{E}$ and that between the latter and the equatorial water mass showing lower $\mathrm{S} / \mathrm{E}$ are defined rather distinctly, but the distribution of $S / E$ in other parts of the far oceanic water in the Central North Pacific does not show any clear discontinuous lines as far as the collections examined are concerned, although the above-mentioned trends are discernible.

b) Distribution of $\mathbf{S} / \mathrm{E}$ in other parts of the Indo-Pacific based on available data.

i) Near the Japanese waters. In Tables 61-63 and 73 B are given values of S/E calculated from the following material: Sôyô-Maru (TokIoKA, 1957); western Japan 


\begin{tabular}{|c|c|c|c|c|c|c|c|c|c|c|c|c|c|c|c|}
\hline \multirow{2}{*}{60} & \multicolumn{3}{|c|}{$\begin{array}{c}\text { Palaa } \\
\text { New Gulnea }\end{array}$} & \multicolumn{3}{|c|}{$\begin{array}{l}\text { Jopanese N.E. } \\
\text { Woters }\end{array}$} & \multicolumn{3}{|c|}{ Tronspoc Exp. } & \multicolumn{3}{|c|}{ Midpoc Exp. } & \multicolumn{3}{|c|}{ Equapoc Exp. } \\
\hline & $H / E$ & $s / E$ & $P / E$ & $H / E$ & s/E & $P / E$ & $H / E$ & $S / E$ & $P / E$ & $H / E$ & $S / E$ & $P / E$ & $H / E$ & $s / E$ & $P / E$ \\
\hline $0 / 0$ & 1 & & 1 & 2 & 1 & 2 & 21 & 5 & 14 & & & & & & \\
\hline 0 & 6 & 2 & 4 & 4 & 1 & 4 & 24 & 3 & 12 & & & & & & \\
\hline$*-0.10$ & 1 & $i^{\prime}$ & 1 & & & & & & 1 & & & & & 1 & \\
\hline $0.11-0.50$ & 1 & 2 & 2 & & 1 & & 3 & 2 & 8 & 3 & & 1 & 4 & 2 & 4 \\
\hline $0.51-1.00$ & & 1 & & & 1 & & & 3 & 3 & 1 & & 4 & 1 & 1 & 1 \\
\hline $1.01-2.00$ & & 2 & 1 & & 1 & & 2 & 7 & 2 & 1 & 1 & & & 1 & \\
\hline $2.01-5.00$ & & & & & & & & 10 & 3 & & 4 & & & & \\
\hline $5.01-10.00$ & & & & & & & & 3 & & & & & & & \\
\hline$>10.01$ & & & & & & & & 1 & & & & & & & \\
\hline$\infty$ (enflata 0$)$ & & 1 & & & 1 & & 2 & 18 & 9 & & & & & & \\
\hline Number of samples & & 9 & & & 6 & & & 52 & & & 5 & & & 8 & \\
\hline
\end{tabular}

\begin{tabular}{|c|c|c|c|c|c|c|c|c|c|c|c|c|c|c|c|}
\hline 0 & 7 & 2 & 5 & 6 & 2 & 6 & 45 & 8 & 26 & & & & & & \\
\hline$*-1.00$ & 2 & 4 & 3 & & 2 & & 3 & 5 & 12 & 4 & & 5 & 5 & 4 & 5 \\
\hline $1.01-\infty$ & & 3 & 1 & & 2 & & 4 & 39 & 14 & 1 & 5 & & & 1 & \\
\hline
\end{tabular}

Table 60. Occurrence of respective values of $\mathrm{H} / \mathrm{E}, \mathrm{S} / \mathrm{E}$ and $\mathrm{P} / \mathrm{E}$ in samples collected in the bedoti-free water masses in the western half of the North Pacific in materials examined (west of $160^{\circ} \mathrm{W}$ ). $* \cdots$ present, but less than $1 \%$

(TокіокA, 1940); Kii-Channel connecting the eastern end of the Inland Sea with the open sea (MURAKami, 1959); small collection from the Japan Sea (FuruHAShI, 1953); New Yamato Bank in the Japan Sea (TokiokA, 1951) ; Sagami and Suruga Bays from May 1936 to April 1937 (ТокіокA, 1954); and a dense patch of chaetognaths that appeared near the Seto Marine Biological Laboratory on Feb. 25, 1954 (TokiokA, 1954); together with some fragmentary data.

Tôkyô Bay-According to MuraKam's data (1959), in the 44 samples collected from the mouth of the bay, the following frequencies prevailed-S. enflata $47 \%, S$. hexaptera $14 \%$, S. serratodentata pacifica $5 \%$, and $P$. draco $9 \%$. The water of this region is evidently bedoti-water as mentioned previously (Frequency of Occurrence of $S$. bedoti-47\%), and S/E is apparently lower than 1.00 . S. hexaptera occurred in six samples, in the two of these the species exceeded $S$. enflata as $1: 0$ and $5: 2$. 

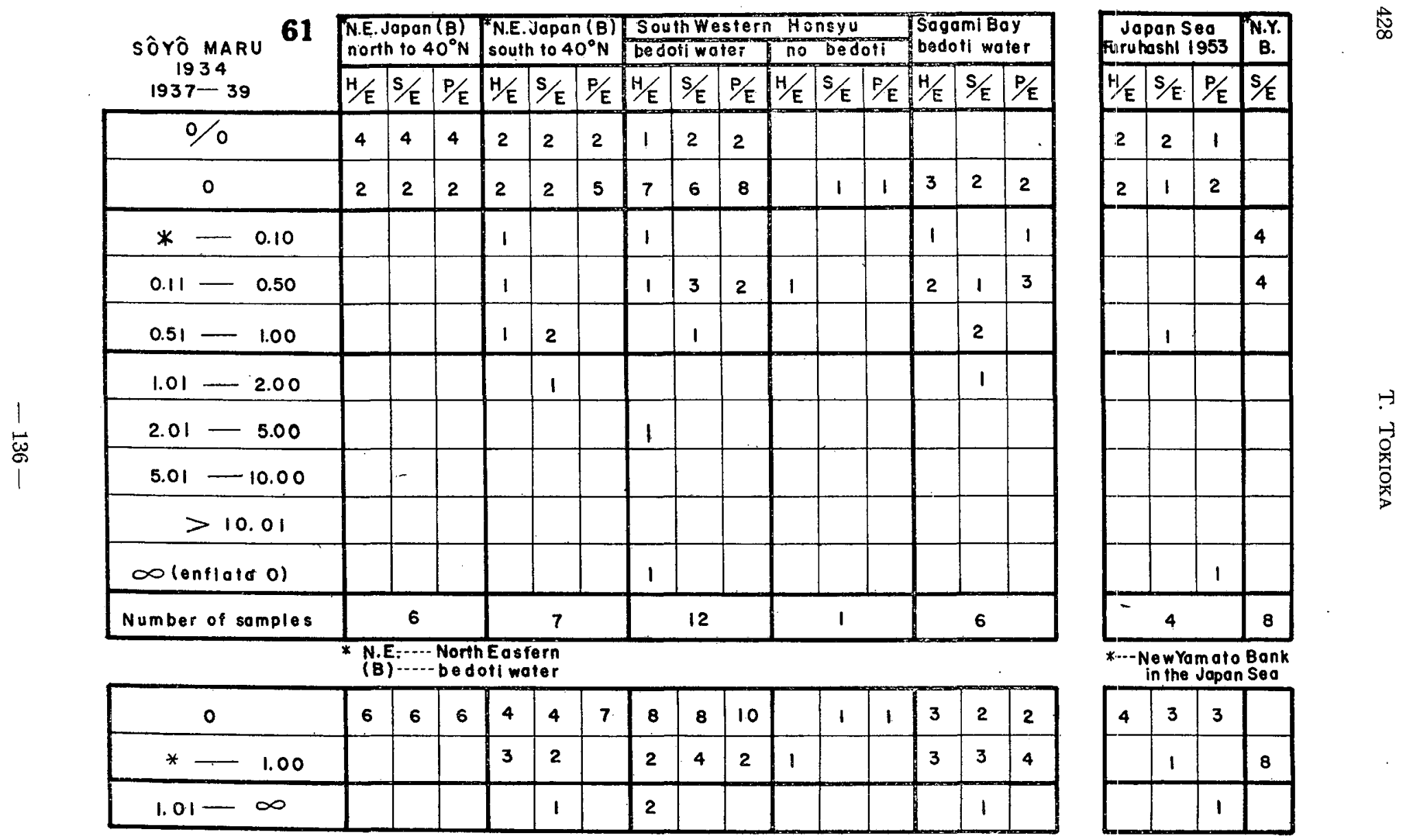

Table 61. Occurrence of respective values of $\mathrm{H} / \mathrm{E}, \mathrm{S} / \mathrm{E}$ and $\mathrm{P} / \mathrm{E}$ in plankton samples collected

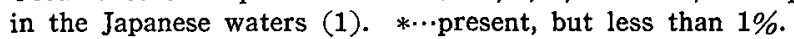




\begin{tabular}{|c|c|c|c|c|c|c|c|c|c|c|c|c|c|c|c|c|c|c|}
\hline 62 & Woter & s off & he Sc & suther & Kyus & & & 081 & $\mathrm{Chi}$ & & Soa & & & outh & $\mathrm{Ch}$ & $n a$ & & \\
\hline & bedo & in wa & & no & bed & & bedo & II wo & ter & no & bed & oा & bedo & $\pi$ wa & er & & 58 & गणा \\
\hline $1937-3$ & $H / E$ & $s / E$ & $P / E$ & $H / E$ & $S / E$ & $P / E$ & $H / E$ & $S / E$ & $P / E$ & $H / E$ & $S / E$ & $P / E$ & $H / E$ & $s / E$ & $P / E$ & $H / E$ & $s / E$ & $P / E$ \\
\hline$\%$ & & & & & & & & & & 1 & & 1 & & & & & & \\
\hline 0 & 2 & 1 & 4 & 1 & & 2 & 2 & 2 & 2 & 1 & & 1 & 5 & 3 & 6 & 3 & 3 & 3 \\
\hline$*-0.10$ & & $\mathbf{I}$ & & & & & & & & & & & & 1 & & & & \\
\hline $0.11-0.50$ & 1 & 1 & & 1 & & & & & & & & & 1 & 1 & & & & \\
\hline $0.51-1.00$ & 1 & & & & & & & & & & 1 & & & & & & & \\
\hline $1.01-2.00$ & & & & & & & & & & & & & & 1 & & & & \\
\hline $2.01-5.00$ & & 1 & & & 2 & & & & & & & & & & & & & \\
\hline $5.01-10.00$ & & & & & & & & & & & & & & & & & & \\
\hline$>10.01$ & & & & & & & & & & & & & & & & & & \\
\hline$\infty($ enflate 0$)$ & & & & & & & & & & & 1 & & & & & & & \\
\hline Number of somples & & 4 & & & 2 & & & 2 & & & 2 & & & 6 & & & 3 & \\
\hline
\end{tabular}

\begin{tabular}{|c|c|c|c|c|c|c|c|c|c|c|c|c|c|c|c|c|c|c|}
\hline 0 & 2 & 1 & 4 & 1 & & 2 & 2 & 2 & 2 & 2 & & 2 & 5 & 3 & 6 & 3 & 3 & 3 \\
\hline$*-1.00$ & 2 & 2 & & 1 & & & & & & & 1 & & 1 & 2 & & & & \\
\hline $1.01-\infty$ & & 1 & & & 2 & & & & & & 1 & & & 1 & & & & \\
\hline
\end{tabular}

Table 62. Occurrence of respective values of $\mathrm{H} / \mathrm{E}, \mathrm{S} / \mathrm{E}$ and $\mathrm{P} / \mathrm{E}$ in plankton samples

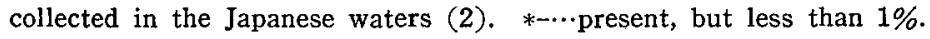




\begin{tabular}{|c|c|c|c|c|c|c|c|c|c|c|c|c|}
\hline 63 & Wate & s off & hew & istari & Kyus & & Wote & irs of & the & Sout1 & hernk & yusyu \\
\hline TOKIOKA & bod & $\pi \mathrm{WO}$ & & no & bec & $\sqrt{0+1}$ & bed & Oाl wo & & no & bed & का \\
\hline 1940 & $H / E$ & $S / E$ & $P / E$ & $H / E$ & $S / E$ & $P / E$ & $H / E$ & $s / E$ & $P / E$ & $H / E$ & $\mathrm{~S} / \mathrm{E}$ & $P / E$ \\
\hline$\%$ & 4 & 1 & 3 & & & & 1 & 1 & 1 & & & \\
\hline 0 & 2 & 2 & 2 & & & & 8 & 6 & 8 & 3 & 3 & 2 \\
\hline * -0.10 & 1 & & & & & & & & 3 & & & 2 \\
\hline $0.11-0.50$ & 1 & 1 & 2 & 1 & & 1 & 3 & 3 & & 1 & 1 & \\
\hline $0.51-1.00$ & & 1 & & & 1 & & & 1 & & & & \\
\hline $1.01-2.00$ & & & & & & & & 1 & & & & \\
\hline $2.01-5.00$ & & & & & & & & & & & & \\
\hline $5.01-10.00$ & & & & & & & & & & & & \\
\hline$>10.01$ & & & & & & & & & & & & \\
\hline$\infty$ (enflato 0$)$ & & 3 & 1 & & & & & & & & & \\
\hline Number of samples & & 8 & & & 1 & & & 12 & & & 4 & \\
\hline
\end{tabular}

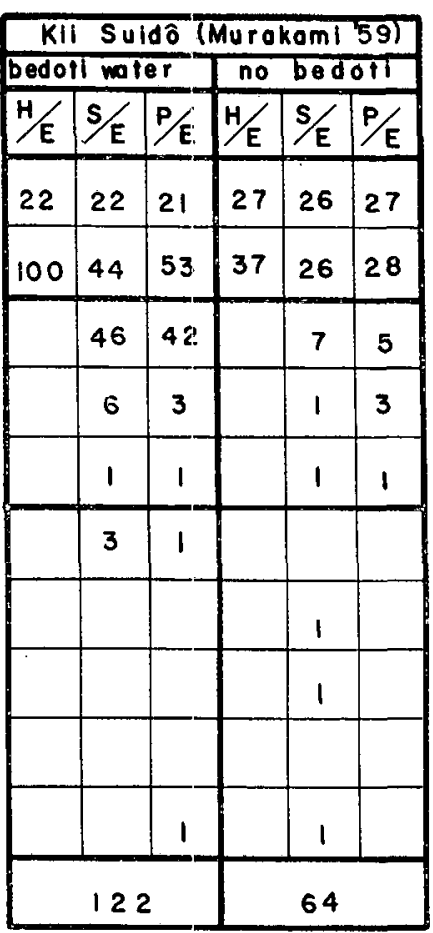

\begin{tabular}{|c|c|c|c|c|c|c|c|c|c|c|c|c|}
\hline 0 & 6 & 3 & 5 & & & & 9 & 7 & 9 & 3 & 3 & 2 \\
\hline$*-1.00$ & 2 & 2 & 2 & 1 & 1 & 1 & 3 & 4 & 3 & 1 & 1 & 2 \\
\hline $1.01-\infty$ & & 3 & 1 & & & & & 1 & & & & \\
\hline
\end{tabular}

\begin{tabular}{|c|c|c|c|c|c|}
\hline 122 & 66 & 74 & 64 & 52 & 55 \\
\hline & 53 & 46 & & 9 & 9 \\
\hline & 3 & 2 & & 3 & \\
\hline
\end{tabular}

Table 63. Occurrence of respective values of $\mathrm{H} / \mathrm{E}, \mathrm{S} / \mathrm{E}$ and $\mathrm{P} / \mathrm{E}$ in plankton samples collected in the Japanese waters (3). $* \cdots$ present, but less than $1 \%$. 
Bungo Channel-This is the channel connecting the south-western end of the Inland Sea and the open sea. Twelve samples were examined by Murakami (1959). S. enflata occurred in four of them, but no S. serratodentata pacifica, S. hexaptera, nor $P$. draco were found in the material. This region is a mixing area between the crassa-water of the Inland Sea and the bedoti-water off south-western Honsyu.

The Japan Sea-In 32 samples treated by Tokioka (1940), S. enflata occurred at a frequency of $30 \%$, while S. hexaptera, S. serratodentata pacifica and $P$. draco were quite absent. Of the material from the waters near the New Yamato Bank (TokIokA, 1951), only $\mathrm{S} / \mathrm{E}$ of the vertical hauls are shown in Table 61. S. hexaptera was not found in the vertical hauls and only two specimens of $P$. draco occurred in a single sample. On the other hand, 13 of the 66 surface hauls contained S. enflata, but no $S$, hexaptera, $S$. serratodentata pacifica nor $P$. draco were represented in the material. The surface water of this region is evidently bedoti-water, but the water in deeper layers is mixed with elegans-water as in the region where FuRUHASHI (1953) collected his samples $\left(36^{\circ} 05.2^{\prime} \mathrm{N}-36^{\circ} 32^{\prime} \mathrm{N} \times 133^{\circ} 39.0^{\prime} \mathrm{E}-135^{\circ} 41.5^{\prime} \mathrm{E}\right)$. In these waters S. minima was very abundant as mentioned previously (p. 404). In 32 samples collected in the crassa or bedoti-water of the Korea Straits (ToKIOKA, 1940), S. enflata occurred at a frequency of $63 \%$ and S. serratodentata pacifica at a frequency of $6 \%$, while both $S$. hexaptera and $P$. draco were absent.

The Yellow Sea-In twenty-six samples examind (TokiokA, 1940), no S. enflata, $S$. hexaptera, S. serratodentata pacifica nor $P$. draco were detected.

The East China Sea-In twelve samples collected in the characteristic bedotiwater near the Chu San Islands (TokiokA, 1940), S. enflata occurred at a frequency of $42 \%$, but $S$. hexaptera, S. serratodentata pacifica or $P$. draco were quite absent.

All these data appear to indicate a tendency of $S$. enflata to be abundant while $S$. serratodentata pacifica is very scarce within the range of the distribution of $S$. bedoti, and this does not regard the presence or absence of $S$. bedoti in respective samples. However, in the areas where the bedoti-water is adjacent to far oceanic water or is mixing with the latter, some masses of various sizes of far oceanic water may be carried into the bedoti-water in various degree and consequently remarkably high values of $\mathrm{S} / \mathrm{E}$ are sometimes met with as is shown in the case of the dense chaetognath patch that appeared at Seto.

ii) The South China Sea and the Philippine waters (Tables 62, 64 and 66). In the samples collected near Hainan Island (Table 62), $\mathrm{S} / \mathrm{E}$ is lower than 1.00 in most cases. The value should be also very low near Nhatrang-Cauda, Viet Nam, because HAMON (1956) gives the following data: (A) In 58 samples...S. enflata-2644 individuals in the material, and occurred at a frequency of $59 \% ; S$. hexaptera did not occur in the material; S. serratodentata pacifica-only 4 individuals in the material, and occurred at a frequency of $2 \%$; and $P$. draco-only 2 in the material, and occurred at a frequency of $2 \%$. (B) In 17 samples collected by Dr. M. RANSON ...S. enflata-7796 individuals in the material, and occurred at a frequency of $100 \%$; 


\begin{tabular}{|c|c|c|c|c|c|c|c|c|c|c|c|c|c|c|c|c|c|c|}
\hline & & 10 & Seo & Ts & & & & ulu & Se & & Tsb & & & elebe & & seo & 15 & \\
\hline Sn SNELLIUS & bedo1 & wat & & no & bed & & bedo & fi wo & ter & no & bed & ofi & bedo & iwal & & no & bed & \\
\hline Sb SIBOGA & $\mathrm{H} / \mathrm{E}$ & $s / E$ & $P / E$ & $H / E$ & $S / E$ & $P / E$ & $H / E$ & $S / E$ & $P / E$ & $H / E$ & $5 / E$ & $P / E$ & $H / E$ & $S / E$ & $\mathrm{P} / \mathrm{E}$ & $\mathrm{H} / \mathrm{E}$ & $S / E$ & $P / \varepsilon$ \\
\hline $0 / 0$ & & & & 1 & 1 & 1 & & & & & & & & & & 14 & 11 & 13 \\
\hline 0 & 6 & 1 & 6 & 4 & i & 4 & & 1 & 1 & 1 & 1 & & 35 & 3 & 17 & 21 & 7 & 19 \\
\hline$*-0.10$ & & 3 & 2 & & & & 2 & 1 & 1 & & & 1 & 3 & 6 & 15 & & 4 & 3 \\
\hline $0.11-0.50$ & & 1 & & & 1 & & & & & & & & 3 & 9 & 6 & 1 & 5 & 2 \\
\hline $0.51-1.00$ & 1 & 1 & & & & & & & & & & & & 14 & 5 & 1 & 2 & \\
\hline $1.01-2.00$ & 1 & 2 & & & & & & & & & & & 1 & 5 & & 1 & 2 & \\
\hline $2.01-5.00$ & & & & & 2 & & & & & & & & 1 & 5 & 1 & & 2 & \\
\hline $5.01-10.00$ & & & & & & & & & & & & & $\mathbf{I}$ & & & & & \\
\hline$>10.01$ & & & & & & & & & & & & & & 2 & & & 2 & \\
\hline$\infty($ enflata 0$)$ & & & & & & & & & & & & & & & & & 3 & 1 \\
\hline Number of somples & & 8 & & & 5 & & & 2 & & & 1 & & & 44 & & & 38 & \\
\hline
\end{tabular}

\begin{tabular}{|c|c|c|c|c|c|c|c|c|c|c|c|c|c|c|c|c|c|c|}
\hline 0 & 6 & 1 & 6 & 5 & 2 & 5 & & 1 & 1 & 1 & 1 & & 35 & 3 & 17 & 35 & 18 & 32 \\
\hline$*-1.00$ & 1 & 5 & 2 & & 1 & & 2 & 1 & 1 & & & 1 & 6 & 29 & 26 & 2 & 11 & 5 \\
\hline $1.01-\infty$ & 1 & 2 & & & 2 & & & & & & & & 3 & 12 & 1 & 1 & 9 & 1 \\
\hline
\end{tabular}

Table 64. Occurrence of respective values of $H / E, S / E$ and $P / E$ in plankton samples hauled

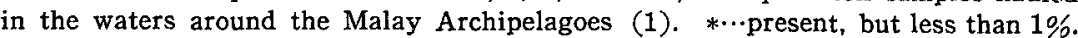




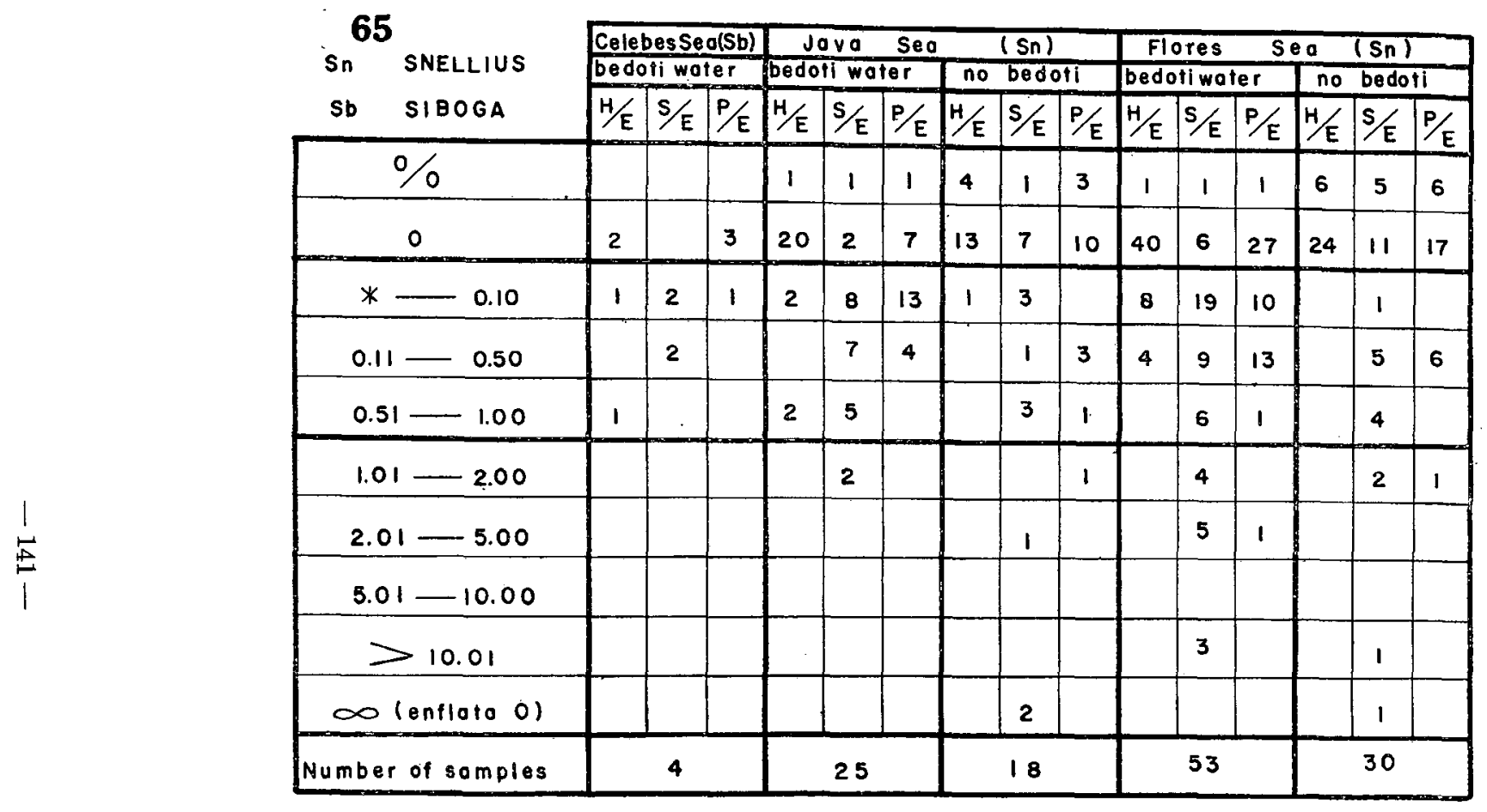

\begin{tabular}{|c|c|c|c|c|c|c|c|c|c|c|c|c|c|c|c|}
\hline 0 & 2 & & 3 & 21 & 3 & 8 & 17 & 8 & 13 & 41 & 7 & 28 & 30 & 16 & 23 \\
\hline$*-1.00$ & 2 & 4 & 1 & 4 & 20 & 17 & 1 & 7 & 4 & 12 & 34 & 24 & & 10 & 6 \\
\hline $1.01-\infty$ & & & & & 2 & & & 3 & 1 & & 12 & 1 & & 4 & 1 \\
\hline
\end{tabular}

Table 65. Occurrence of respective values of $\mathrm{H} / \mathrm{E}, \mathrm{S} / \mathrm{E}$ and $\mathrm{P} / \mathrm{E}$ in plankton samples hauled in the water around the Malay Archipelagoes (2). * *..present, but less than $1 \%$. 


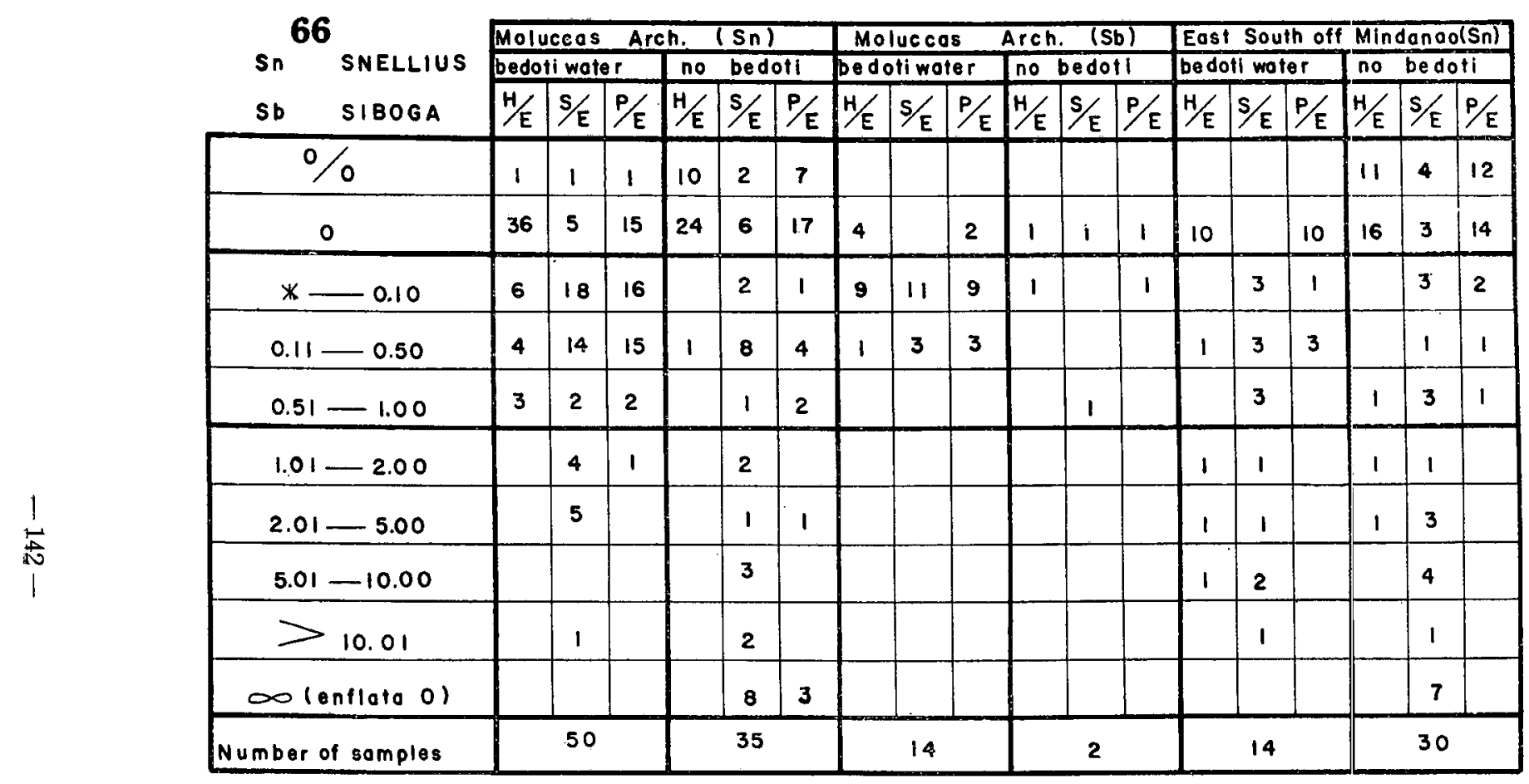

\begin{tabular}{|c|c|c|c|c|c|c|c|c|c|c|c|c|c|c|c|c|c|c|}
\hline 0 & 37 & 6 & 16 & 34 & 8 & 24 & 4 & & 2 & 1 & 1 & 1 & 10 & & 10 & 27 & 7 & 26 \\
\hline$*-1.00$ & 13 & 34 & 33 & 1 & 11 & 7 & 10 & 14 & 12 & 1 & 1 & 1 & 1 & 9 & 4 & 1 & 7 & 4 \\
\hline $1.01-\infty$ & & 10 & 1 & & 16 & 4 & & & & & & & 3 & 5 & & 2 & 16 & \\
\hline
\end{tabular}

Table 66. Occurrence of respective values of $\mathrm{H} / \mathrm{E}, \mathrm{S} / \mathrm{E}$ and $\mathrm{P} / \mathrm{E}$ in plankton samples hauled

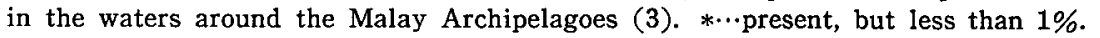




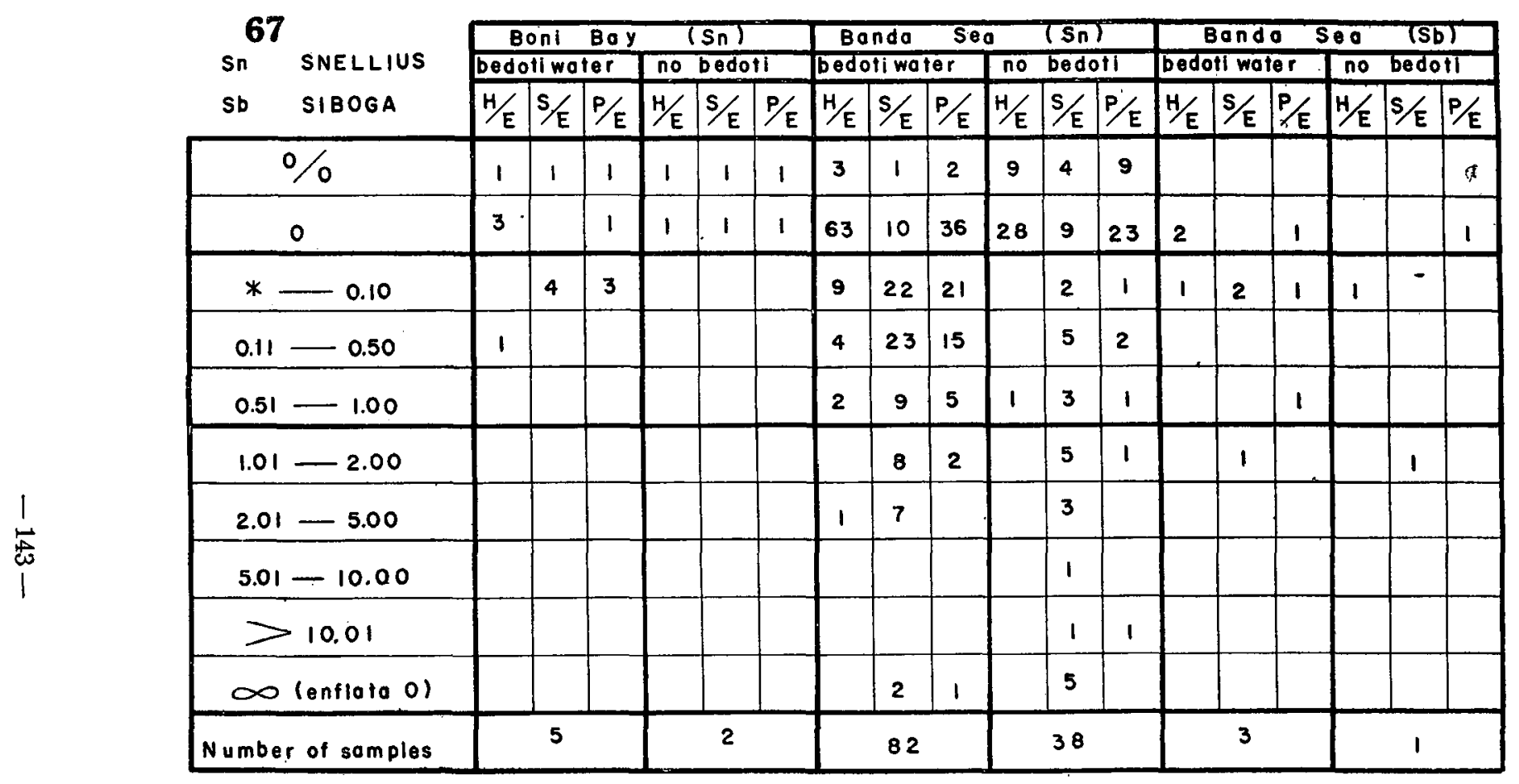

\begin{tabular}{|c|c|c|c|c|c|c|c|c|c|c|c|c|c|c|c|c|c|c|}
\hline 0 & 4 & 1 & 2 & 2 & 2 & 2 & 66 & 11 & 38 & 37 & 13 & 32 & 2 & & 1 & & & 1 \\
\hline$*-1.00$ & 1 & 4 & 3 & & & & 15 & 54 & 41 & 1 & 10 & 4 & 1 & 2 & 2 & 1 & & \\
\hline $1.01-\infty$ & & & & & & & 1 & 17 & 3 & & 15 & 2 & & 1 & & & 1 & \\
\hline
\end{tabular}

Table 67. Occurrence of respective values of $\mathrm{H} / \mathrm{E}, \mathrm{S} / \mathrm{E}$ and $\mathrm{P} / \mathrm{E}$ in plankton samples hauled in the waters around the Malay Archipelagoes (4). * * present, but less than $1 \%$. 


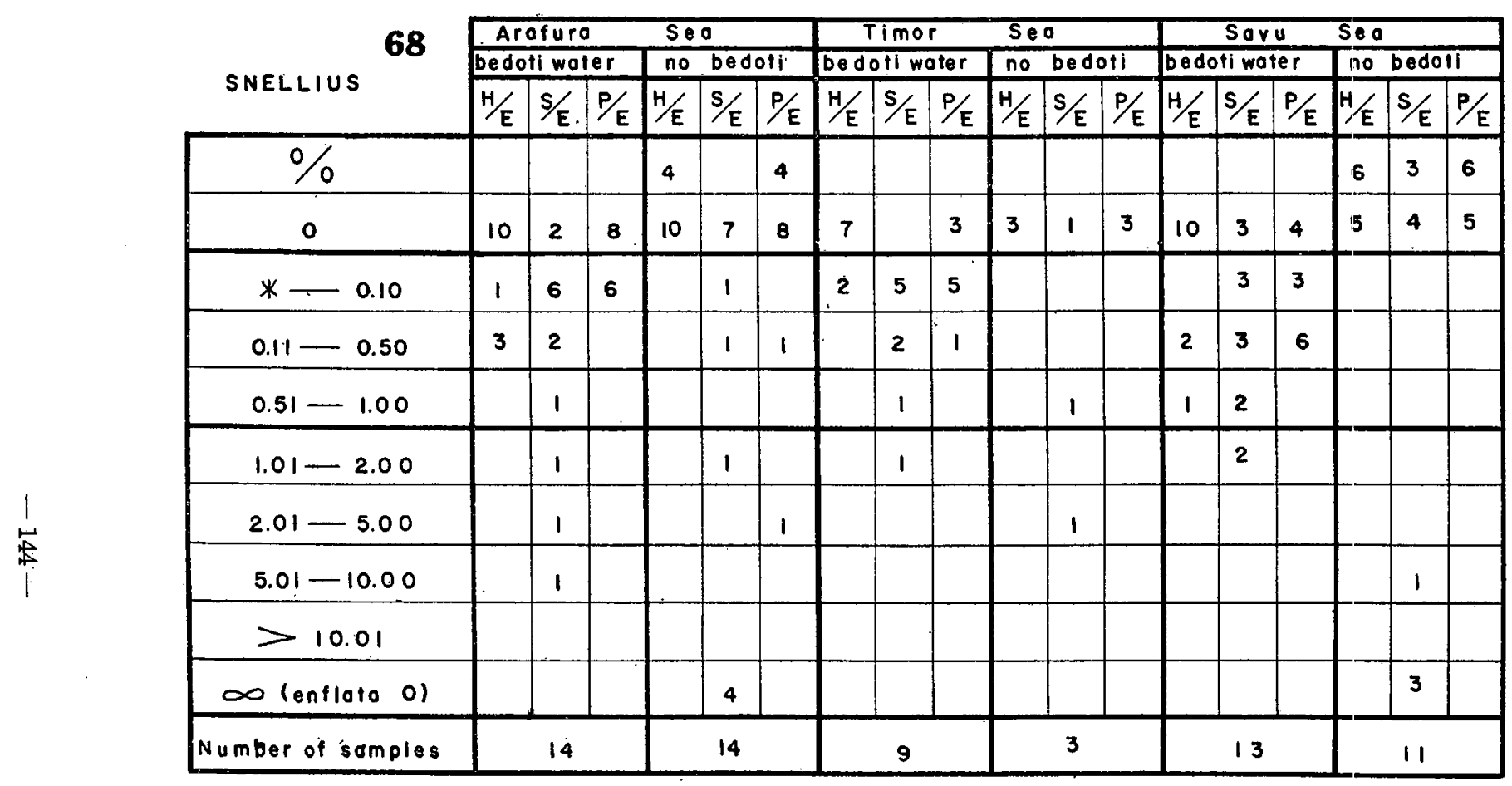

\begin{tabular}{|c|c|c|c|c|c|c|c|c|c|c|c|c|c|c|c|c|c|c|}
\hline 0 & 10 & 2 & 8 & 14 & 7 & 12 & 7 & & 3 & 3 & 1 & 3 & 10 & 3 & 4 & 11 & 7 & 11 \\
\hline$*-1.00$ & 4 & 9 & 6 & & 2 & 1 & 2 & 8 & 6 & & 1 & & 3 & 8 & 9 & & & \\
\hline $1.01-\infty$ & & 3 & & & 5 & & & 1 & & & 1 & & & 2 & & & 4 & \\
\hline
\end{tabular}

Table 68. Occurrence of respective values of $\mathrm{H} / \mathrm{E}, \mathrm{S} / \mathrm{E}$ and $\mathrm{P} / \mathrm{E}$ in plankton samples hauled in the waters around the Malay Arhipelagoes (5). *...present, but less than 1\%. 
$S$, hexaptera did not occur in the material; $S$. serratodentata pacifica-18 individuals in the material, and occurred at a frequency of $18 \%$; and $P$. draco did not occur in the material.

During the Albatross Expedition in the Philippine waters, chaetognaths were collected at 46 stations in the area extending $5^{\circ} 36^{\prime}-21^{\circ} 31^{\prime} \mathrm{N} \times 117^{\circ} 53^{\prime}-127^{\circ} 44^{\prime} \mathrm{E}$. In this material, the four species under consideration occurred in the following proportion (MICHAEL, 1919): S. enflata-2800 individuals in the material, and occurred at a frequency of $85 \%$; S. hexaptera-700 individuals in the material, and occurred at a frequency of $57 \%$; S. serratodentata-100 individuals in the material, and occurred at a frequency of $15 \%$; and $P . d r a c o-22$ individuals in the material, and occurred at a frequency of $11 \%$. It is evident that $\mathrm{S} / \mathrm{E}$ must be very low in the Philippine waters.

iii) The waters around the. Malay Archipelagoes (Tables 64-69 and $73 \mathrm{~B}$ ). Many data from this area are divided into two groups, namely those from samples collected in the bedoti-water masses and those hauled in the water masses containing no $S$. bedoti. Throughout the Tables $64-68$ and $73 \mathrm{~B}$, it is easily noted that higher

\begin{tabular}{|c|c|c|c|}
\cline { 2 - 4 } \multicolumn{1}{c|}{69} & bedoti water mass & non bedoti-water mass & \\
\hline Sulu Sea (Sn.) & 3.00 & 1.50 & 0 \\
\hline Sulu Sea (Sb.) & $\infty$ & $\infty$ & \\
\hline Celebes S. (Sn.) & 2.67 & 3.22 & \\
\hline Celebes S. (Sb.) & $\infty$ & - & 0 \\
\hline Moluccas Arch. (Sn.) & 4.00 & 1.19 & \\
\hline Moluccas Arch. (Sb.) & $\infty$ & $\infty$ & 0 \\
\hline $\begin{array}{c}\text { East south off } \\
\text { Mindanao }\end{array}$ & 1.80 & 0.88 & 0 \\
\hline Java Sea & 11.50 & 5.00 & $\times$ \\
\hline Flores Sea & 3.42 & 6.50 & \\
\hline Boni Bay & $\infty$ & $\infty$ & 0 \\
\hline Banda Sea (Sn.) & 3.82 & 1.53 & 0 \\
\hline Banda Sea (Sb.) & 2.00 & 0.00 & 0 \\
\hline Arafura Sea & 3.67 & 1.80 & 0 \\
\hline Timor Sea & 8.00 & 2.00 & 1.75 \\
\hline Savu Sea & 5.50 & & 0 \\
\hline Table & & & \\
\hline The va & & & \\
\hline
\end{tabular}

Table 69. The value of $\mathrm{S} / \mathrm{E}$ lower than $1.00 / \mathrm{S} / \mathrm{E}$ higher than 1.00 in various parts of the waters around the Malay Archipelagoes.

$O$...the value higher in bedoti-water than in non-bedoti-water.

$x \cdots$ the value higher in non-bedoti-water than in bedoti-water. 


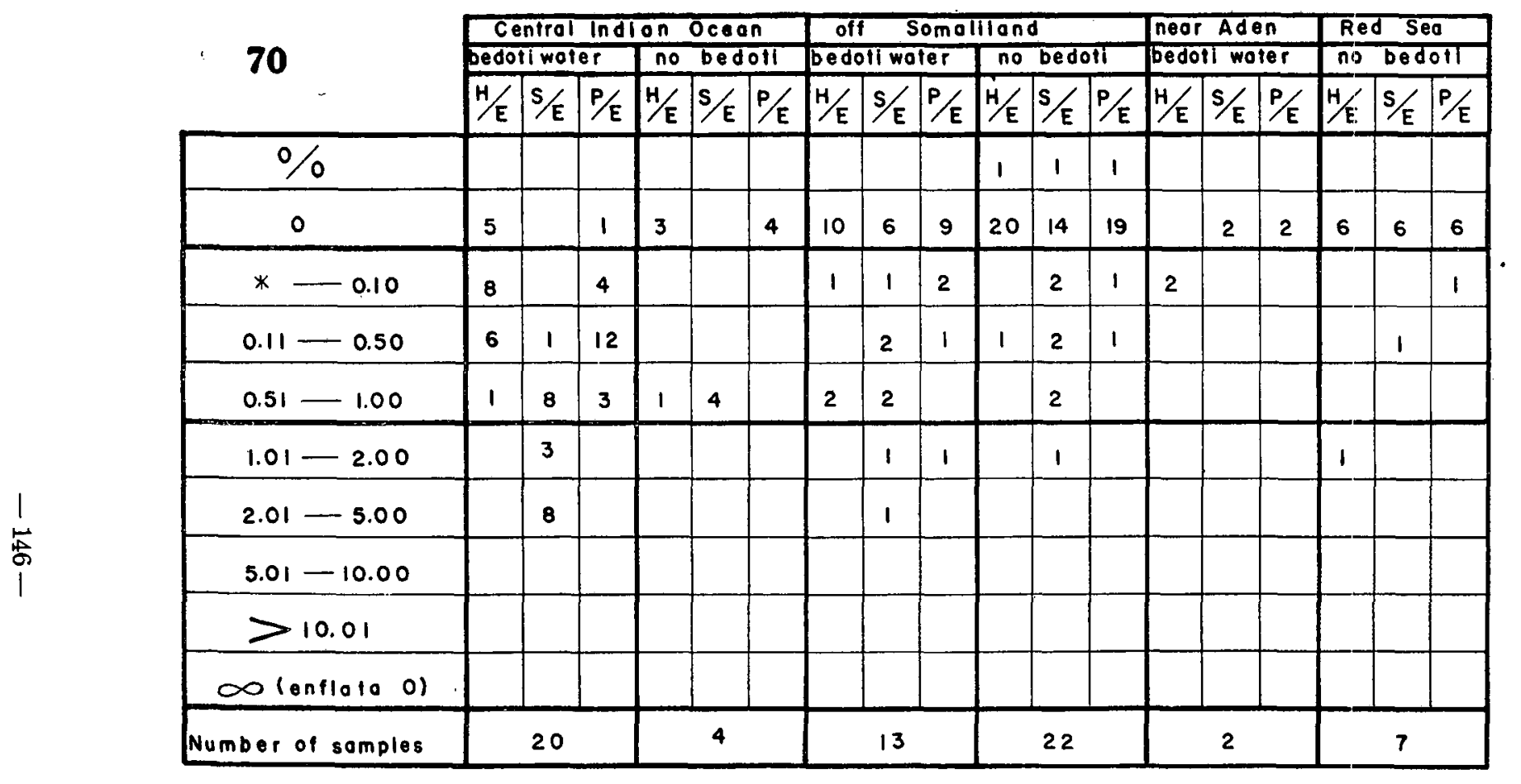

\begin{tabular}{|c|c|c|c|c|c|c|c|c|c|c|c|c|c|c|c|c|c|c|}
\hline 0 & 5 & & 1 & 3 & & 4 & 10 & 6 & 9 & 21 & 15 & 20 & & 2 & 2 & 6 & 6 & 6 \\
\hline$*-1.00$ & 15 & 9 & 19 & 1 & 4 & & 3 & 5 & 3 & 1 & 6 & 2 & 2 & & & & 1 & 1 \\
\hline $1.01-\infty$ & & 11 & & & & & & 2 & 1 & & 1 & & & & & 1 & & \\
\hline
\end{tabular}

Table 70. Occurrence of respective values of $H / E, S / E$ and $P / E$ in plankton samples collected in the Indian Ocean and the adjacent waters. *...present, but less than $1 \%$. 
values of $\mathrm{S} / \mathrm{E}$ seem to occur more frequently in the non-bedoti-water masses than in the bedoti-water masses. The value $\frac{\mathrm{S} / \mathrm{E} \text { lower than } 1.00}{\mathrm{~S} / \mathrm{E} \text { higher than } 1.00}$ in various parts of the waters around the Malay Archipelagoes are given in Table 69. OYE (1918) examined samples collected at 77 stations in the Java Sea and showed the proportion of the four species as follows: S. enflata occurred at a frequency of $97 \%$ and constituted $31 \%$ of the whole collection of chaetognaths, S. hexaptera occurred at a frequency of $64 \%$ and constituted $5 \%$ of the whole collection of chaetognaths, while S. serratodentata did not occur and P. draco occurred at a frequency of only $1 \%$. He states that the absence of $S$. serratodentata in the material is a result of only surface towing, while the species is probably a mesoplanktonic form. This is, however, not likely, because most samples of the Snellius material were also collected in the surface layer and yet they comprised a considerable number of S. serratodentata. However, his data can be safely accepted in support of the tendency of S. serratodentata to be very scarce in this area of bedoti-water as compared to the far oceanic waters. In 55 samples from the Arafura and Timor Seas, examined by Токіока (1955b), $S$. serratodentata pacifica and $P$. draco were extremely scarce and $S$. hexaptera was quite absent. The water of the Arafura Sea was of the typical bedoti-water at that time.

iv) The Indian Ocean (Tables 70 and $73 \mathrm{~B}$ ). Besides the data on the material from the central Indian Ocean (TokIOKA, 1956), the material collected by the "Cherso" from the Red Sea and from the waters along Somaliland (GHIRARDELLI, 1948) and a small collection from the North Eastern part of the Ocean (Nicobar, Nias and Bali-Lombok) shown in Tables 70 and $73 \mathrm{~B}$, there are the following fragmentary data :-

In a single sample collected near Ceylon (TokiokA, 1956), $\mathrm{H} / \mathrm{E}$ was $0, \mathrm{~S} / \mathrm{E} 6.5$ and $P / E$ was 2.5. In a single sample hauled in the Red Sea (300-0 $\mathrm{m}$, in April 1929) by the Snellius (Schilp, 1941), H/E was $4.6, \mathrm{~S} / \mathrm{E} 0.4$ and $\mathrm{P} / \mathrm{E}$ was 0 . It is somewhat strange that $\mathrm{S} / \mathrm{E}$ is rather high even in the bedoti-water mass in the central part of the Indian Ocean. Since S. serratodentata pacifica can be used as an indicator of oceanic water in the waters off Visakhapatnam near Waltair (S. RAo and GANAPATI, 1958, p. 167) and BuRfield (1926) shows that $S$. serratodentata is most abundant in the surface layer of this ocean, the above-mentioned phenomenon might indicate that the water of the surveyed area in the central Indian Ocean still retains in considerable degree, the characteristics of far oceanic water in spite of the existence of $S$. bedoti.

v) Along the Eastern coast of Australia (Tables 71-72). THOMson (1947) gives the frequency of occurrence of the four species in the waters of south-eastern Australia as in Table 71. The rate of increase in the oceanic water is much higher in S. pacifica than in S. enflata, but probably $S$. enflata is more abundant than S. pacifica in both neritic and oceanic waters. BURFIELD (1950) shows the proportion of the four species 


\begin{tabular}{|c|c|c|}
\cline { 2 - 3 } \multicolumn{1}{c|}{71 F.O. } & $\begin{array}{l}\text { at } 161 \text { neritic stations over } \\
\text { the continent shelf }\end{array}$ & $\begin{array}{l}\text { at } 113 \text { oceanic stations be- } \\
\text { yond the continent shelf }\end{array}$ \\
\hline Sag. enflata & $51.5 \%$ & $54.0 \%$ \\
\hline Sag. hexaptera & $22.4 \%$ & $58.4 \%$ \\
\hline Sag. pacifica & $31.6 \%$ & $46.0 \%$ \\
\hline Pterosag. draco & $30.4 \%$ & $62.8 \%$ \\
\hline
\end{tabular}

Table 71. Distribution of four important species in the waters of the SouthEastern Australia (THOMSON, 1947).

\begin{tabular}{|l|c|c|}
\cline { 2 - 3 } \multicolumn{1}{c|}{72} & inside the reefs & outside the reefs \\
\hline Sag. enflata & 110728 ind. & 14735 ind. \\
\hline Sag. hexaptera & 243 & 837 \\
\hline Sag. pacifica & 3 & 64 \\
\hline Pterosag. draco & 5 & 74 \\
\hline
\end{tabular}

Table 72. Distribution of four important species in the Great Barrier Reef region (BuRfield, 1950).

in the Great Barrier Reef region as above: $\mathrm{S} / \mathrm{E}$ is clearly higher in the waters outside the reefs, althoug the dominancy of $S$. enflata is still retained there. Both of these surveyed areas belong to bedoti-water.

vi) Central part of the Pacific (Table $72 \mathrm{~A}$ and $\mathrm{B}$ ). The material of the SyunkotuMaru (ToKIOKA, 1954) indicates distinctly that $\mathrm{S} / \mathrm{E}$ is higher in the North Equatorial Current than in the Counter Equatorial and South Equatiorial Currents. $S / E$ is also lower than 1.00 in the material collected near the Phoenix and Gilbert Islands.

vii) Off Chile (Table $73 \mathrm{~A}$ ). FAGETrI (1958) examined 220 samples collected from the waters off north and middle Chile. In her material, $S$. hexaptera occurred only once and $P$. draco did only five times, while $S$. pacifica occurred at a frequency of $36 \%$. S/E seems to vary from time to time, but the dominancy of S. enflata was maintained throughout the whole material.

All of the data, quoted here, indicates that $S$. enflata is very rich in the bedotiwater, while $S$. serratodentata pacifica increases towards the offshore oceanic waters and the $\mathrm{S} / \mathrm{E}$ becomes higher in the far oceanic water, excepting the area along the equatorial zone. The influx of the North Equatorial Current retaining higher $\mathrm{S} / \mathrm{E}$ flows into the waters around the Malay Archipelagoes, and consequently the values of $\mathrm{S} / \mathrm{E}$ higher than 1.00 occur rather frequently in this area. The dominance of $S$. enflata in the Shellback area is maintained also in the waters off north to middle Chile, although the frequency of occurrence of $\mathrm{S} / \mathrm{E}$ higher than 1.00 seems to be higher in the latter to some extent. 

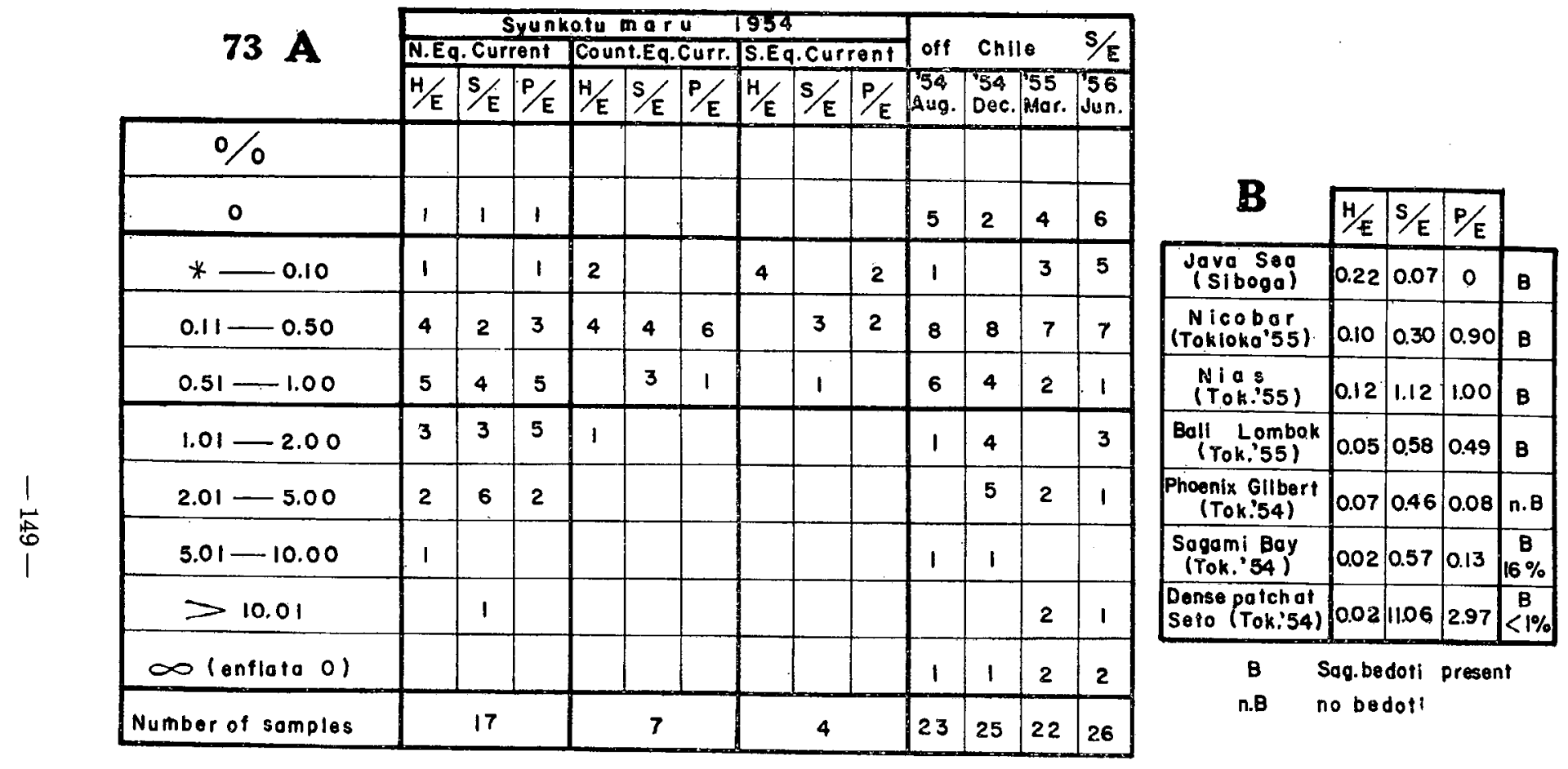

\begin{tabular}{|c|c|c|c|c|c|c|c|c|c|c|c|c|c|}
\hline 0 & 1 & 1 & 1 & & & & & & & 5 & 2 & 4 & 6 \\
\hline$*-1.00$ & 10 & 6 & 9 & 6 & 7 & 7 & 4 & 4 & 4 & 15 & 12 & 12 & 13 \\
\hline $1.01-\infty$ & 6 & 10 & 7 & 1 & & & & & & 3 & 11 & 6 & 7 \\
\hline
\end{tabular}

B Sag.bedoli present

n.B no bedol:

Table 73. Occurrence of respective values of $\mathrm{H} / \mathrm{E}, \mathrm{S} / \mathrm{E}$ and $\mathrm{P} / \mathrm{E}$ in plankton samples came

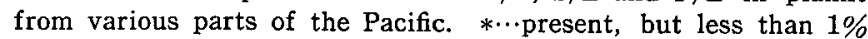




\section{c) Distribution of $\mathbf{H} / \mathbf{E}$.}

As the number of specimens of $S$. hexaptera collected during the Transpac Expedition with a small net from the surface water above $50 \mathrm{~m}$ is very small, it is quite imposiible to establish any trends in the distribution of this species from the data of this expedition. As shown in Table 57 indicating the results of the German Atlantic Expedition by the "Meteor" the population of $S$. hexaptera is relatively large in deeper layers as compared with those of $S$ enflata and $S$. serratodentata. For instance, let us compare the two columns of Appendix Table 1 No. 4, which show the chaetognath populations of the two samples collected at the same station respectively by a small net from $50 \mathrm{~m}$ to surface and by a large net from $450 \mathrm{~m}$ to the surface. In the sample of *TP 131 from the deeper water, a considerable number of $S$. hexaptera were found and actually the number was larger than that of $S$. enflata. But the animals seem to easily avoid being caught when a smaller net is used or when the haul is limited to the surface layer. The same phenomena are seen also in the results of the Snellius Expedition, in which S. hexaptera occurred commonly in samples collected from the deep waters, but very scarcely in those collected by towing a small net in the surface water.

However, in examining the tables and data given in the preceding section (b, i-vii), it may be safely said that $S$. hexaptera shows a tendency to decrease in the bedoti-water and the adjacent waters, while increasing in the offshore far oceanic waters. The distribution of this species in a part of the far oceanic water of the Central North Pacific is shown by HIDA (1957), who illustrates very distinctly that the species is one of the most important chaetognaths in the subtropic and the transition zones between meridians $145^{\circ} \mathrm{W}-170^{\circ} \mathrm{E}$ and consequently $\mathrm{H} / \mathrm{E}$ is enormously large in this area. TokiokA (1955) also stated that the proportion of S. hexaptera increases towards the north in a limited area in the central Pacific, covering the North Equatorial Current, the Counter Equatorial Current and a part of the South Equatorial Current. The raise of $\mathrm{H} / \mathrm{E}$ towards the north in far oceanic waters cannot be considered to result only from the decrease of $S$. enflata; it can result by actual increase of $S$. hexaptera.

Looking through Tables 64-68 and $73 \mathrm{~B}$, showing the proportional abundance of the four species near the Malay Archipelagoes, $S$. hexaptera and $P$. draco seem superficially to occur more frequently and abundantly in the bedoti-water masses than in the non-bedoti-water masses. But, this is rather questionable, because most of the larger samples collected from the deep waters are included in the column of the bedoti-water. And it is evident that the frequency of occurrence of S. hexaptera and $P$. draco is much higher in the larger samples from deep waters than in smaller samples collected by towing in the surface water, and the same applies to S. bedoti. Hence, the occurrence of the first two species together with $S$. bedoti should be more frequent than those two species alone in the region within the range of the distribution of S. bedoti. 


\section{d) Distribution of $\mathbf{P} / \mathbf{E}$.}

The distribution of $P$. draco in the bedoti-water resembles that of S. hexaptera; it is rather scarce there, but increases considerably in far oceanic waters. In the far oceanic water of the Central North Pacific, the population of this species is larger in the southern half than in the northern half where it decreases very sharply and is scarcely found in the northern parts. HIDA's statement (1957) on the distribution of this species in the area, mentioned in the preceding section, shows clearly this trend; there, $P$. draco is abundant in the subtropic zone south to ca. $33^{\circ} \mathrm{N}$, but decreases sharply in the transition zone.

\section{e) Distribution of other prominent species.}

i) S. bipunctata, HidA (1957) includes this species as a very important form in the subtropic and transition zones, considering it comparable with S. serratodentata. Actually it occurred in considerable numbers at considerable frequencies in the Transpac Expedition collections as shown in Appendix Table 1, but it was much scarcer than S. serratodentata pacifica. It is not improbable that this species occurs abundantly in rather deep water and consequently is met with less frequently in the present material of the Transpac Expedition, which consists only of samples gathered from $50 \mathrm{~m}$ to the surface. BIERI (1959) say that the distribution of S. californica ( $=S$. bipunctata) is antitropical, avoiding a narrow band in the equatorial region. The results of my examination on five of the samples of the Equapac Expedition show that S. bipunctata is not so rare in this region. It occurred also in considerale numbers in the material of the Syunkotu-Maru and also in the small sample from the GilbertPhoenix Islands, while it was quite absent in the materials of the Palao-New Guinea cruises. Probably, the population of S. bipunctata fluctuates rather violently in the equatorial region.

ii) S. regularis. According to the present data from the material examined, this species seems to occur more frequently and abundantly in the western half of the Central North Pacific than in the eastern half. It is found abundantly in waters adjacent to the bedoti-water in the western North Pacific, but this does not seem to suggest any special correlation between this species and $S$. bedoti, because the former is rather scarce in the bedoti-water of the Shellback area. In the central equatorial part of the Indian Ocean, the species occurs much more abundantly than does S. hexaptera.

iii) S. minima. The abundance of this species in or near the region of mixing between the elegans-water and the warm water has been repeatedly explained in previous sections. Its dominance is especially pronounced in the north-eastern part of the far oceanic water of the Central North Pacific, because S. enflata and even $S$. serratodentata pacifica are very scarce there. In the mixing area, it might easily be mistaken for young individuals of S. elegans, because the general external appearance is nearly the same between these two species. Very probably some slight errors are inevitable in counting these forms in the mixing area. However, the direction of 
fin rays, which is vertical in S. minima rather than oblique as in S. elegans, can be used as the apparent characteristic in separating immature $S$, minima and young S. elegans. S. minima is also fairly common in the waters off North and Central Chile (FAGETTI, 1958). Sometimes it occurs in considerable density in the tropical waters as seen in the material from the central equatorial part of the Indian Ocean (TOKIOKA 1956a) and in the material of the Eastropic Expedition (Sund, 1959c), although it is still very difficult, at present, to explain clearly the significance of such distributions.

\section{DIFFERENTIATION FOUND IN THE CHAETOGNATH FAUNA OF THE NORTH PACIFIC AND THE RELATION BETWEEN COMMUNITIES AND WATER MASSES}

The contents of the foregoing sections may be summarized as follows :-

\section{1) Chaetognath fauna in the embayments.}

i. West side of the North Pacific:- Crassa-water in the Inland Sea, Ise Bay, Tôkyô Bay and Mutu Bay of Honsyû, Japan, also in the coastal waters of Korea and in Kiauchau Bay of North China. Delicata-water in Maizuru Bay, Tanabe Bay, Katu-ura Bay and Ago Bay of Honsyâ, Japan.

ii. East side of the North Pacific:- Tenuis-water in lagoons and small bays or inlets along lower California.

\section{2) Bedoti-water.}

i. West side of the North Pacific:- (1) In the mixing area between the bedoti-water and the elegans-water or between the former and the crassa-water in the Yellow Sea, respectively $S$. elegans and $S$. bedoti or $S$. crassa and $S$. bedoti represent the components of the fauna. In the former region S. minima and a small number of $S$. enflata may join the fauna at times.

(2) Then, there is a fairly wide area in the Yellow Sea and the East China Sea, where $S$. bedoti and $S$. enflata are the chief components.

(3) The greatest part of the bedoti-water is the mixing region between (2) and the w $\vec{n} \mathrm{~m}$ oceanic water, where most of the warm oceanic species occur together with $S$. bedoti, although they are not so abundant as in the far oceanic water. Here, S. enflata predominates over other forms including $S$. serratodentata pacifica, $S$. hexaptera is very scarce. $P$. draco occurs in the southern part, but not in abundance. S. regularis is relatively common.

ii. East side of the North Pacific:- The bedoti-water here is characterized as in (3) mentioned in the preceding paragraph. The predominance of S. enflata over S. serratodentata pacifica is maintained here also. S. hexaptera occurs in considerable numbers as does also $P$. draco, since the area is situated in the tropics. However, $S$. regularis is rather scarce. Other than these species, there occur also in this area $S$. serratodentata tasmanica, $S$. neodecipiens, $S$. ferox f. americana and $S$. friderici. These are quite unknown from the western bedoti-water and according to present data S. neodecipiens and S. ferox f. americana are strictly confined to this area. Thus, the difference between the western and eastern bedoti-water is somewhat remarkable. 
3) Friderici-water along the Californian coast (cit. p. 390).

\section{4) Elegans-water.}

It is unnecessary to discuss at length this very distinct subarctic water which together with $S$. elegans is inhabited by considerable numbers of $E$. hamata and a small number of $S$. lyra. Besides these, Heterokrohnia mirabilis is reported by Tchindonova (1955) from the depths of the Kamchatka trench. In the mixing area between the elegans-water and adjacent far oceanic water, some deeper living species join $S$. elegans and $E$. hamata as important parts of the chaetognath fauna. These are $S$. decipiens and $S$. planctonis in the western Canadian coastal waters (LEA, 1955) and S. hexaptera, S. bipunctata and $S$. serratodentata in the area from $170^{\circ} \mathrm{E}$ to $145^{\circ} \mathrm{W}$ (HIDA, 1957) besides those mentioned already on pp. 389-390.

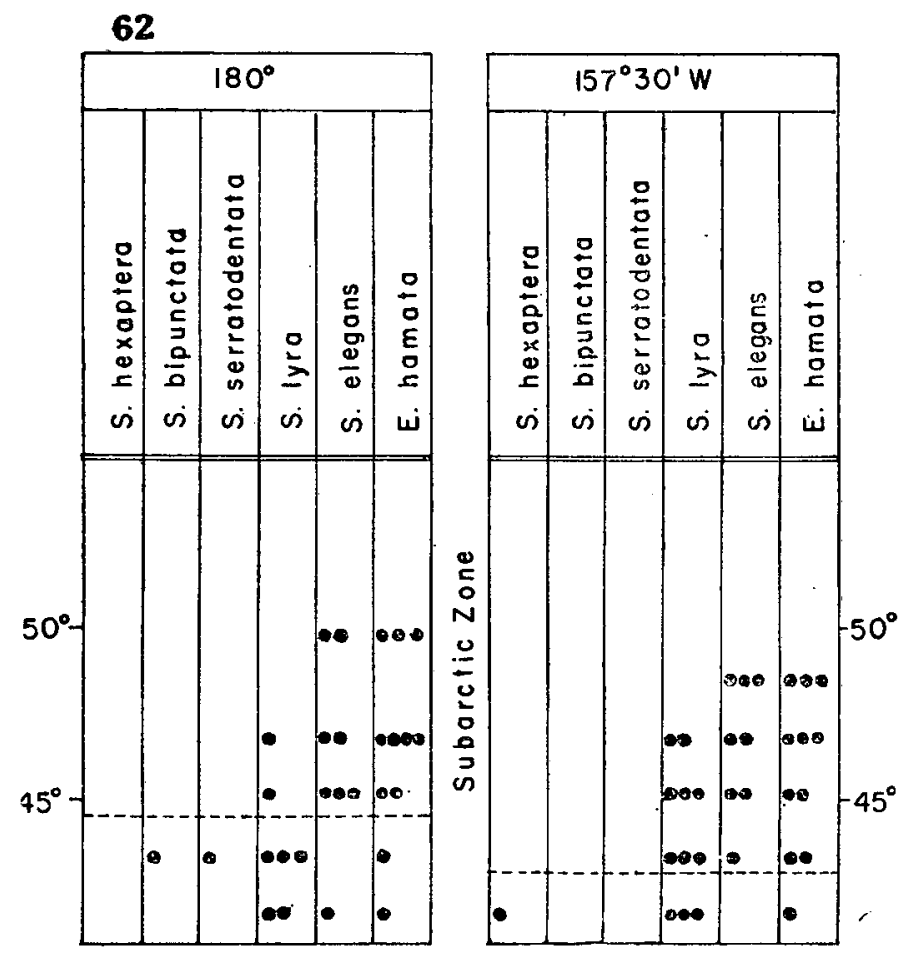

Fig. 32. Chaetognath fauna in the mixing area between the elegans-water and the North Pacific Central Water. (A part of Fig. 5 in HIDA's paper, 1957.)

\section{5) Enflata dominant Equatorial water.}

Here S. enflata predominates over S. serratodentata pacifica. BIERI $(1959$, p. 25) states that "the absence of S. pulchra, S. neglecta, S. bedoti and S. pseudoserratodentata, with S. robusta, S. regularis, and Krohnitta pacifica present, would place the sample in the oceanic region of the Equatorial Water Mass"; most probably the scarcity of S. bipunctata should be added to this in his opinion. In treating my data, I could discern clearly only a trend towards the S/E lower than 1.00 in this region; the samples I dealt with are rather few and too small to review BIERI's statement. 


\section{6) Pacifica-dominant oceanic water.}

In this vast area of far oceanic water, $S$. serratodentata pacifica predominates numerically over $S$. enflata. This area can be divided into a northern transition zone characterized by prominent increase in S. minima and S. lyra and a southern subtropical to tropical zone characterized by the abundance of $P$. draco as is shown by HIDA (1957). The northern part is much narrower than the southern part. At the same time, this area is divisible into western and eastern halves, although the distinction is not very clear in the distribution of chaetognaths. The frequent occurrence of numerous $S$. regularis and relatively large population of $S$. enflata contrasted with more scarce occurrence of $S$. hexaptera are characteristics of the tauna in the western half and the extreme scarceness of $S$. enflata and $S$. regularis and the comparatively abundant occurrence of $S$. hexaptera are the features characterizing the fauna in the eastern half. These are all deductions from only the available material that I have examined and hence it is not certain whether or not all these trends are absolutely of universal or constant features. BIERI (1959) says "the absence of $S$. robusta and $S$. regularis, with $S$. pseudoserratodentata present, would show that the sample came from the Eastern North Pacific Central Water". At least, the scantiness of $S$. regularis in the eastern half is common to both Breri's and my statements.

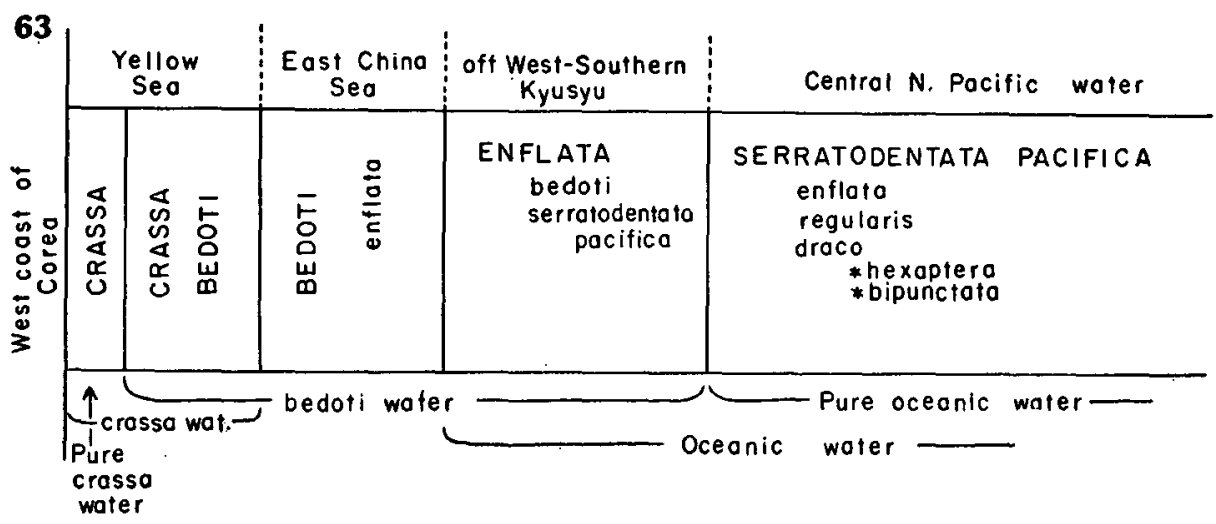

Fig. 33. Differentiation found in the chaetognath fauna along the line through the Yellow Sea, East China Sea, waters off West-South Kyûsyû and extending to the North Pacific Central Water.

It is evident that (5), enflata-dominant Equatorial Water, corresponds to Pacific Equatorial Water and that (6), pacifica-dominant oceanic water, cor responds to North Pacific Central Water. The predominance of S. serratodentata over S. enflata seems to be a characteristic of far oceanic water, since in the South Atlantic S. serratodentata was about 1.7 times as numerous as $S$. enflata as a whole, when the individuals of each species in a cylinder of water, $1000 \mathrm{~m}$ deep and $50 \mathrm{~m}$ in diameter, were compared (THIEL, 1938). As to the approximate situation of the boundary between the western and eastern halves of the chaetognath fauna in the North Pacific Central Water, I cannot add anything to the comment by BIERI (1959), since the material I dealt with is much smaller than his. HIDA (1957) made a comparison of chaetognath faunas in the subarctic, transition, and subtropic zones along $180^{\circ}$ and $157^{\circ} 30^{\prime} \mathrm{W}$ as found on 


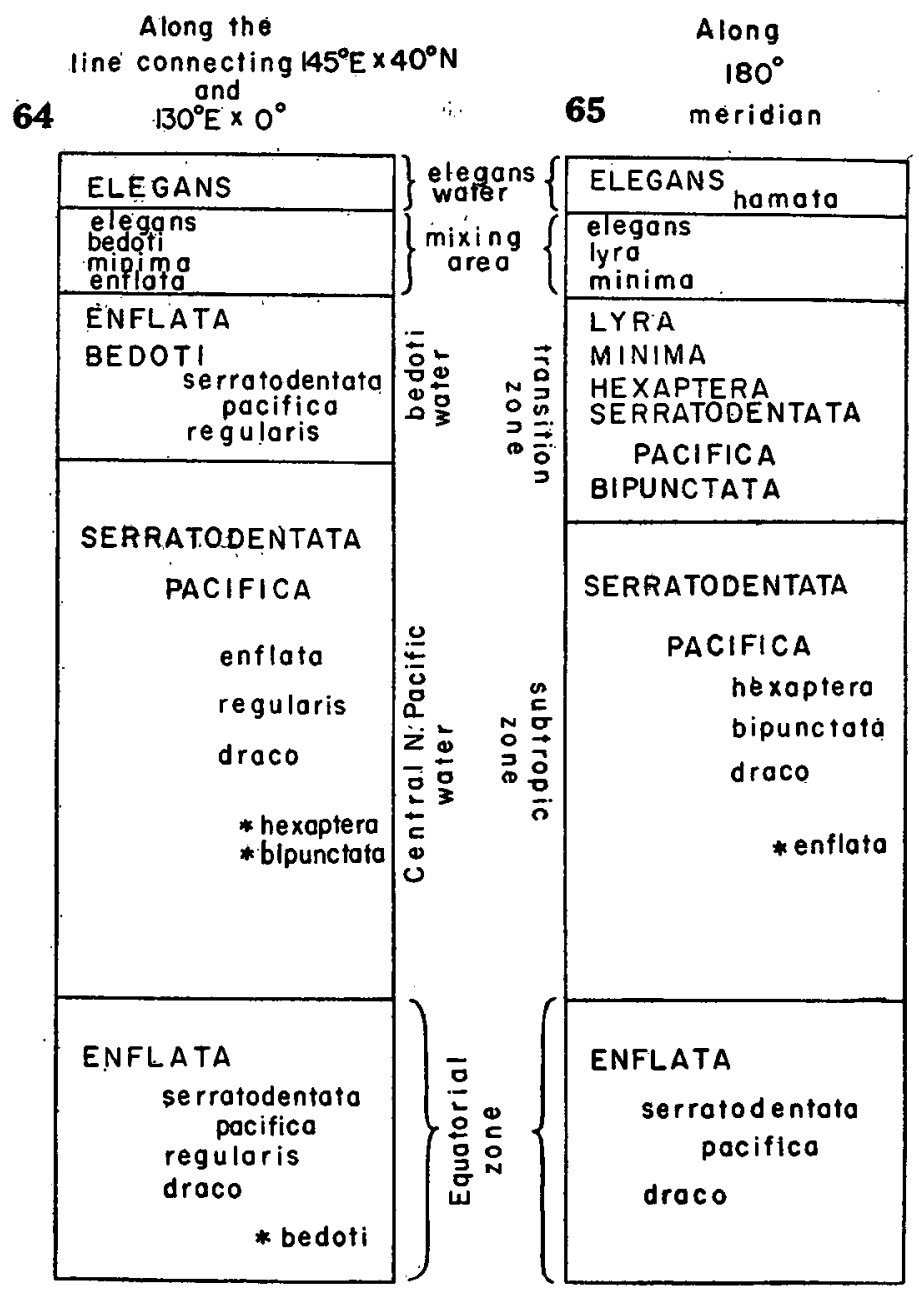

Fig. 34. Differentiation found in the chaetognath fauna along the line connecting $145^{\circ} \mathrm{E} \times 40^{\circ} \mathrm{N}$ and $130^{\circ} \mathrm{E} \times 0^{\circ}$ (64) and along $180^{\circ}$ meridian (65).

Hugh M. Smith Cruise 30. The slight narrowing of the transition zone along $157^{\circ} 30 \mathrm{~W}$ and the relative abundance of $S$. minima in the transitionz one along $180^{\circ}$ is shown in his Fig. 5 , but these do not seem to indicate any distinct boundaries between the east and western Central Wasters. Consequently, it is best, at present, to refrain from any attempts to correlate the Western and Eastern North Pacific Central Waters with the chaetognath fauna. The abun-

\begin{tabular}{|l|c|}
\hline 74 \\
\hline Sag. serratodentata & 305 \\
\hline Sag. enfiata & 179 \\
\hline Pterosag. draco & 66 \\
\hline Sag. hexaptera & 59.3 \\
\hline
\end{tabular}

Table 74. Proportion of four important species in the South Atlantic. (THIEL, 1938). 


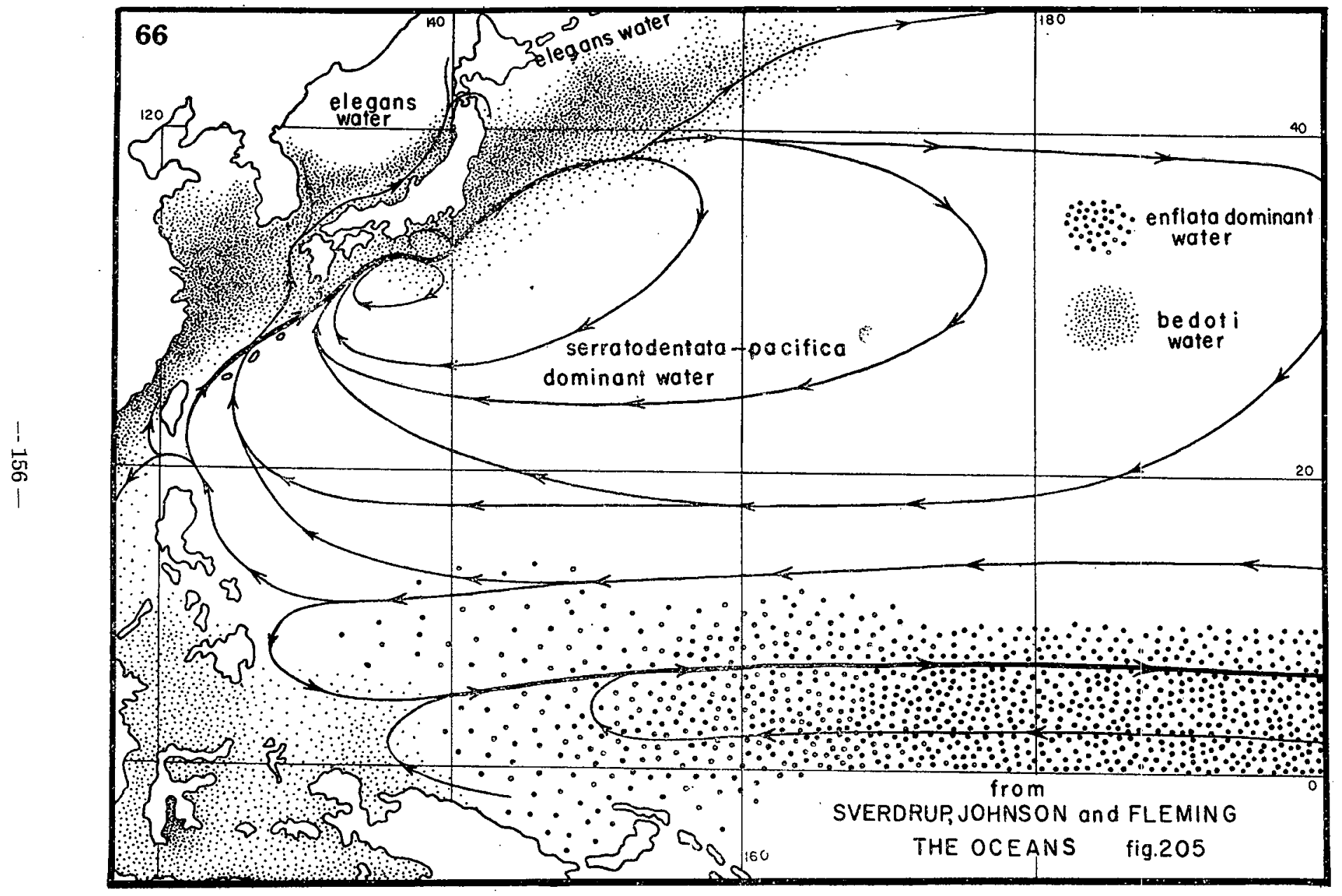

Fig. 35. Distribution of the bedoti-water and the enflata-dominant equatorial water plotted on the current chart from "The Ocean". 
dance of $S$. enflata in the bedoti-water and the Equatorial water is significant in that both the bedoti-water and the Equatorial water hold denser population of not only chaetognaths but also of many other plankton organisms than does the North Pacific Central Water. S. regularis is abundant in the western half of both the North Pacific Central water and Equatorial water. It is very strange therefore that the species decreases greatly towards the east in spite of the existence of the eastward flowing Counter Equatorial Current. The degree of the lateral mixing along this current, which might induce dispersion or intake of various species of chaetognaths, must be studied more in detail in the future.

In the Indo-Pacific, S. friderici occurs only in the coastal waters along the western coast of the New World and the known occurrence of $S$. tenuis seems to confine it to the same region. These two species are reasonably considered as relicts of the Caribbean chaetognaths showing an ancient connexion between the Pacific and the Caribbean Sea, at which time they might have been carried into the Pacific by the westward Equatorial Current. But probably species characteristic to the Pacific, such as $S$. bedoti and S. regularis, could not penetrate into the Caribbean Sea against this current. At first, it appeared that $S$. ferox f. americana might be closely related with S. hispida or S. helenae in the Caribbean Sea, but this is not likely. The existence of more anterior teeth than posterior teeth in many individuals is merely a superficial coincidence between this and $S$. helenae; the existence of the distinct intestinal diverticula in $S$. ferox f. americana seems to be enough to separate it distinctly from $S$. helenae which lacks completely the intestinal diverticula. The distinction between this and S. hispida seems to be clear, though it is somewhat delicate as mentioned in the taxonomic part. Most probably this form differentiated from an ancestral ferox-group in the eastern bedoti-water as $S$. neodecipiens apparently did. S. hispida and $S$. helenae known commonly from the Caribbean Sea might have differentiated there after the connexion between that sea and the Pacific was closed and hence they do not occur in the Shellback area to-day. It is difficult to consider the western and eastern bedoti-waters in the Pacific as having developed independently of each other; long ago these two bedoti-waters might have been continous with each other. The differentiation of S. neodecipiens and S. ferox f. americana in the eastern bedoti-water seems to have started after the continuity between the eastern and western bedoti-waters was cut off. The chaetognath fauna in the eastern bedoti-water is evidently nourished partly by the northward Humboldt Current, since there are found a considerable number of $S$. serratodentata tasmanica and a small number of a special form of S. enflata (f. gardineri) having longer ovaries. Both of these are known from the waters off North and Central Chile.

\section{Summary and Conclusions}

1. A part of the plankton material, 326 samples in all, collected by and stored at the Scripps Institution of Oceanography were examined and the data obtained 
concerning chaetognaths are given in 7 appended tables. Data from samples of the Palao-New Guinea cruises (1940) made by a Japanese survey ship are also given in an appended table.

2. Thirty forms of chaetognaths were discriminated throughout the whole material, one of these is a new species and another is a new form. A comparison was made between Pacific specimens of $S$. tenuis and $S$. friderici. Some notes are also given on the morphology and the range of variations in certain other species.

3. The chaetugnathi faumas of several eñibayments, the biue-green water along the Californian coast and of the north Subarctic waters are covered briefly.

4. An extensive area characterized by the occurrence of $S$. bedoti is discerned as a water-mass, here called "bedoti-water", which is distinct from the far oceanic water of the North Pacific.

5. The ranges of temperature and salinity of the water containing $S$. bedoti are very wide, leading to the assumption that it is a eurythermal and relatively euryhaline form. The small amount of the interchange of water, under favourable conditions for the species, between the bedoti-water and the adjoining water masses is considered the most important factor confining the species to the bedoti-water. Very probably the number of $S$. bedoti that are diffused into the neighbouring water mass from the "bedoti-water" by interchanging of the water might be less than the minimum required by this species for successful reproduction.

6. The distributions of ratios. between $S$. enflata and each of serratodentata pacifica, hexaptera and $P$. draco $(\mathrm{S} / \mathrm{E}, \mathrm{H} / \mathrm{E}$ and $\mathrm{P} / \mathrm{E})$ were examined. And the relation between these distributions and water masses of the North Pacific was studied. The Equatorial Water Mass is characterized by lower S/E and the North Pacific Central Water Mass is remarkable in maintaining a higher $\mathrm{S} / \mathrm{E}$.

7. The distinction between "bedoti-water" and far oceanic water of the North Pacific Central Water Mass and that between the latter and the Equatorial Water Mass were made clear by the studies mentioned above in 6 . But the boundary between the Western North Pacific Central and the Eastern North Pacific Central Water Masses was not found distinctly by these studies, although the density of some species seems to trend towards one of these two water masses.

\section{REFERENCES}

AIDA, T. (1897): Chaetognaths of Misaki Harbor. Annot. Zool. Japon., Vol. I, pp. 13-21.

BÉRANECK, ED. (1895): Les chétognathes de la baie d'Amboine. Revue Suisse de Zool., 3, pp. 137-159.

Breri, R. (1957): The chaetognath fauna off Peru in 1941. Pacif. Sci., Vol. XI, pp. 255-264.

(1959): The distribution of the plankton Chaetognatha in the Pacific and their relation. ship to the water masses. Limnol. Oceanogr., Vol. IV, No. 1, pp. 1-28.

Burfield, S.T. and Harvey, E.J.W. (1926): The Chaetognatha of the "Sealark" Expedition, Transact. Linn. Soc. London, Vol. XIX, Part 1, pp. 93-119, pls. 4-7.

Burfield, S.T. (1950): Chaetognatha. Great Barrier Reef Exped., Sci. Rep., Vol. V, No. 8, pp. $459-473$. 
DONCASTER, L. (1903): Chaetognatha, with a note on the variation and distribution of the group. The Fauna and Geography of the Maldive and Laccadive Archipelagoes, Vol. I, pp. 209-218.

FAgetTi GuaIta, Elda (1958a): Investigaciones sobre quetognatos colectados, especialmente, frente a la costa central y norte de Chile. Revista Biol. Mar. Valparaiso, Vol. VIII, Nos. 1-3, pp. 25-82.

- (1958b): Quetognato nuevo procedente del Archipelago de Juan Fernandez. Ibid., pp. 125-131.

FAURE, M.L. (1952): Contribution a l'etude morphologique et biologique de deux chaetognathes des eaux atlantiques du Maroc: Sagitta friderici RITTER-ZÁHONY et Sagitta bipunctata QUOY et GaImard. Vie et Milieu, Tom. III, Fasc. 1, pp. 25-43.

Fowler, G.H. (1905): Biscayan plankton of H.M.S. Research. Pt. III Chaetognatha Transact. Linn. Soc. London, Ser. 2, Vol. X, pp. 55-87.

(1906): The Chaetognatha of the Siboga Expedition. Siboga Exped. Monogr. 21, 86 pp., 3 pls., 6 charts.

Furnestin, M.L. (1953a): Contribution à l'étude morphologique, biologique et systématique de Sagitta serrato-dentata KroHN des eaux atlantiques du Maroc. Bull. Inst. Océanogr. (Monaco), No. 1025, 39 pp.

(1953b): Chaetoghathes récoltés en Mediterranée par le "Président Théodore Tissier" aux Mois de Juin et Juillet 1950. Bull. d. Trav. publ. par Stat. Aquicult. \& Pêche Castiglione (Alger), n.s. No. 4, 44 pp.

Furuhashi, K. (1953): On the vertical distribution of animal plankton in the Sea of Japan off San'in-District in summer of 1952. Publ. Seto Mar. Biol. Lab., Vol. III (1), pp. 61-74.

GhIRARDElli. E. (1948): Chetognati racolti nel Mar Rosso e nell'Oceano Indiano dalla nave "Cherso". Boll. Pesca, Piscic. Idrobiol. Vol. II (n.s.), Fasc. 2, pp. 3-20.

- - (1951) : Cicli di maturità sessuale nelle gonadi di Sagitta inflata Grassi del Golfo di Napoli. Boll. Zool., Vol. XVIII, Nos. 4-6, pp. 149-162.

Gray, B.B. (1923): Notes on species of Sagitta collected during a voyage from England to Australia. Proc. Roy. Soc. Queensland, Vol. 34, pp. 171-180.

HAMON, M. (1956): Chétognathes recueillis dans la Baie de Nhatrang-Cauda (Viet-Nam). Bull. Mus. Hist. Nat., Paris, Tom. XXVIII, No. 5, pp. 466-473.

HEYDORN, A.E.F. (1959): The Chaetognatha off the west coast of the Union of South Africa. Invest. Rep. Fish. Mar. Biol. Surv. S. Afr., No. 36, 56 pp., 2 pls.

HIDA, T.S. (1957): Chaetognaths and pteropods as biological indicators in the North Pacific. Spec. Sci. Rep. U.S. Fish \& Wildlife Serv., Fish. No. 215, 13 pp.

JoHN, C.C. (1933): Sagitta of the Madras coast. Bull. Madras Govt. Mus., (Nat. Hist.) N.S., Vol. III, pp. 1-10.

- (1937): Seasonal variations in the distribution of Sagitta of the Madras coast. Rec. Indian Mus., Vol. 39, pp. 83-97.

Johnston, T.H. and TAYloR, B.B. (1919): Notes on the Australian chaetognaths. Proc. Roy. Soc. Queensland, Vol. 31, pp. 28-41.

KING, J.E. and HIDA, T.S. (1957): Zooplankton abundance in the Central Pacific. Fish. Bull. U.S. No. 118 , pp. $365-395$.

LEA, H.E. (1955): The chaetognaths of western Canadian coast waters. J. Fish. Res. Bd. Canada, Vol. 12, No. 4, pp. 593-617.

LELE, S.H. and GAE, P.B. (1936) : Common sagittae of Bombay harbour. J. Univ. Bombay, Vol. 4, pp. 105-113.

MARUMO, R. (1955): Results of the oceanographic observations made in the Eastern waters of Honsyû in Feb.-Mar. 1955. Ocean. Rep. Jap. Met. Ag., Vol. 4 (2), pp. 4-6. (in Japanese)

Marumo, R., Kitou, M. and OHWAdA, M. (1958): Vertical distribution of plankton at $40^{\circ} \mathrm{N}$, $150^{\circ} \mathrm{E}$ in the Oyashio water. Oceanogr Mag., Vol. 10, No. 2, pp. 179-184. 
Massuti, M. (1958): Estudio del crecimiento relativo de Sagitta enflata Grassi del plancton de Castellon. Invest. Pesq., Barcelona, Tom. XIII, pp. 37-48.

Meteorological Agency of Japan (1956-58): Results of the oceanographic observations made in the Eastern and Southern waters of Honsya in the years 1956-57. Ocean. Rep. Jap. Met. Ag., Vol. 5, Nos. 2-4; Vol. 6, No. 4 ; Vol. 7, No. 1. (in Japanese)

MrChaEL, E.L. (1911): Classification and vertical distribution of the Chaetognatha of the San Diego Region. Univ. Calif. Publ. Zool., Vol. VIII, pp. 21-186.

(1919) : Report on the Chaetognatha collected by the U.S. Fisheries Steamer "Albatross" during the Philippine Expedition, 1907-1910. U.S. Nat. Mus. Bull. 100, Vol. 1, Part 4, pp. 235277.

MuRAKAMI, A. (1957): The occurrence of planktonic chaetognaths in the bay and Inland Sea regions (I). On the occurring conditions in Tôkyô Ray, and the central and western parts of Seto-Inland Sea. Suisangaku-Syûsei, Tôkyô Univ., pp. 357-384. (in Japanese)

- (1959): Marine biological study on the planktonic chaetognaths in the Seto Inland Sea. Bull. Naikai Reg. Fish. Lab. No. 12, pp. 1-186. (in Japanese)

Oye, P. (1918): Untersuchungen über die Chaetognathen des Javameeres. Contr. Faune des Indes Neérlandais, Fasc. IV, 61 pp.

Pierce, E.L. (1951): The Chaetognatha of the west coast of Florida. Biol. Bull., Vol. 100, No. 3, pp. 206-228.

(1953): The Chaetognatha over the continental shelf of North Carolina with attention to their relation to the hydrography of the area. Sears Found. J. Mar. Res., Vol. XII, No. 1, pp. $75-92$.

RITTER-ZÁHONY, R. (1909a): Expedition S.M. Schiff "Pola" in der Rote Meer nördliche und südliche Hälfte 1895/96-1897/98. XXII Zoologische Ergebnisse, Chaetognathen. Denkschrift. Math. Naturwiss. K1. Kaiser. Akad. Wiss. Wien, Bd. 84, pp. 1-12.

- (1909b) : Die Chaetognathen der Gazelle-Expedition. Zool. Anz., Bd. 34, pp. 787-793. (1910a): Chaetognatha. Die Fauna Südwest Australiens, Vol. 3, pp. 123-126. (1910b): Westindische Chätognathen. Zool. Jahrb., Suppl. 11, pp. 133-143.

(1911): Revision der Chaetognathen. Deutsche Südpolar Exped., Bd. 13(5), pp. 1-71.

Satyanarayana RaO, T.S. (1958): Studies on Chaetognatha in the Indian Seas, Part II. The Chaetognatha of the Lawson's Bay, Waltair. Andhra Univ. Mem. in Oceanogr., Vol. II, pp. 137-146.

Satyanarayana RaO, T.S. and GaNapatr, P.N. (1958): Studies on Chaetognatha in the Indian Seas. Part III. Systematics and distribution in the waters off Visakhapatnam. Ibid., pp. 147163.

SchILP, H. (1941): Biological results of the Snellius Expedition IX. The Chaetognatha of the Snellius Expedition, Temminckia, Vol. VI, pp. 1-99.

SteINhaus, O. (1896): Die Verbreitung der Chätognathen im südatlantischen und indischen Ozean. Inaug. Diss. Kiel., pp. 1-49.

SuÁrez CAAbro, J.A. (1955): Quetognatos de los mares Cubanos. Mem. Soc. Cubana Hist. Nat., Vol. 22, No. 2, pp. 125-180.

*Subramanyam, M.K. (1940): Sagitta bedoti BÉraneck in Madras plankton. Curr. Sci. (Bangalore), 9, pp. 379-380.

SuND, P.N. (1959a): The distribution of Chaetognatha in the Gulf of Alaska in 1954 and 1956. J. Fish. Res. Bd. Canada, Vol. 16, No. 3, pp. 351-361.

(1959b): A key to the Chaetognatha of the tropical eastern Pacific Ocean. Pacif. Sci. Vol. XIII, No. 3, pp. 269-285.

Sund, P.N. and RENNER, J.A. (1959c): The Chaetognatha of the Eastropic Expedition, with notes as to their possible value as indicators of hydrographic conditions. Inter-American Tropical Tuna Commission Bulletin, Vol. 3, No. 9, pp. 396-436, 27 text-figs., 1 table.

Tchundonova, YU. G. (1955): Chaetognatha of the Kurile-Kamchatka Trench. Trudi Inst. 
Okeanol., 12, pp. 298-310. (in Russian)

THIEL, M.E. (1938): Die Chaetognathen-Bevolkerung des Suidatlantischen Ozeans, Wiss. Ergebn. Deutsch. Atl. Exped. "Meteor". D.A.E. "Meteor" 1925/27, Bd. XIII, pp. 1-110.

Thomson, J.M. (1947): The Chaetognatha of south-eastern Australia. Council Sci. Ind. Res. Australia, Bull. No. 222, 43 pp.

TokiokA, T. (1939a): Chaetognaths collected chiefly from the bays of Sagami and Suruga, with some notes on the shape and structure of the seminal vesicle. Rec. Oceanogr. Wks. Japan, Vol. X, No. 2, pp. 123-150.

- (1939b): Chaetognaths and pelagic tunicates in Ôsaka Bay. Sea and Sky, Vol. 19, No. 6, pp. 152-160. (in Japanese)

- $(1940 \mathrm{a})$ : The Chaetognath fauna of the waters of western Japan. Rec. Oceanogr. Wks. Japan, Vol. XII, No. 1, pp. 1-22.

(1940b): A small collection of chaetognaths from the coast of New South Wales. Rec. Aust. Mus., Vol. 20, No. 6, pp. 367-379.

(1942): Systematic studies of the plankton organisms occurring in Iwayama Bay, Palao. III Chaetognaths from the Bay and adjacent waters. Palao Tropical Biol. St. Studies, Vol. II, No. 3, pp. 527-548.

(1951): Pelagic tunicates and chaetognaths collected during the cruises to the New Yamato Bank in the Sea of Japan. Publ. Seto Mar. Biol. Lab., Vol. II (1), pp. 1-25.

-__ (1954a): Droplets from the plankton net XIII. Emergence of a dense patch of chaetognaths near the Laboratory. Ibid., Vol. III (3), pp. 359-360.

- (1954b): Droplets from the plankton net XVI. On a small collection of chaetognaths from the central Pacific. Ibid., Vol. IV (1), pp. 99-102.

__ (1955a): On some plankton animals collected by the Syunkotu-Maru in May-June 1954. I Chaetognatha. Ibid., Vol. IV (2-3), pp. 219-225.

- (1955b): Droplets from the plankton net. XVII A small collection of chaetognaths and pelagic tunicates from the north eastern part of the Indian Ocean. Ibid., Vol. V (1), pp. $75-78$.

- (1955c): Notes on some chaetognaths from the Gulf of Mexico. Bull. Mar. Sci. Gulf Caribb., Vol. 5, No. 1, pp. 52-65.

- (1956a): On chaetognaths and appendicularians collected in the central part of the Indian Ocean. Publ. Seto Mar. Biol. Lab., Vol. V (2), pp. 197-202.

(1956b): On chaetognaths and appendicularians collected by Mr. Z. Sagara in the Arafura Sea in May-August 1955. Ibid., Vol. V (2), pp. 203-208.

_-_(1957) : Chaetognaths collected by the Sôyo-maru in the years 1934 and 1937-39. Ibid., Vol. VI (2), pp. 137-146.

UYENO, F. and FURUHASHI, K. (1955a): Report of the oceanographic observations made in the southern waters of Honsya in 1954. Ocean. Rep. Jap. Met. Ag., Vol. 4 (1), pp. 62-69. (in Japanese)

(1955b): Report of the oceanographic observations made in the southern waters of Honsyá in March 1955. Ibid., Vol. 4 (2), pp. 20-21. (in Japanese)

(* referred through S. RAO's paper) 


\section{APPENDIX}

Station data 1. For the small-net samples of the Transpac Expedition 1953.

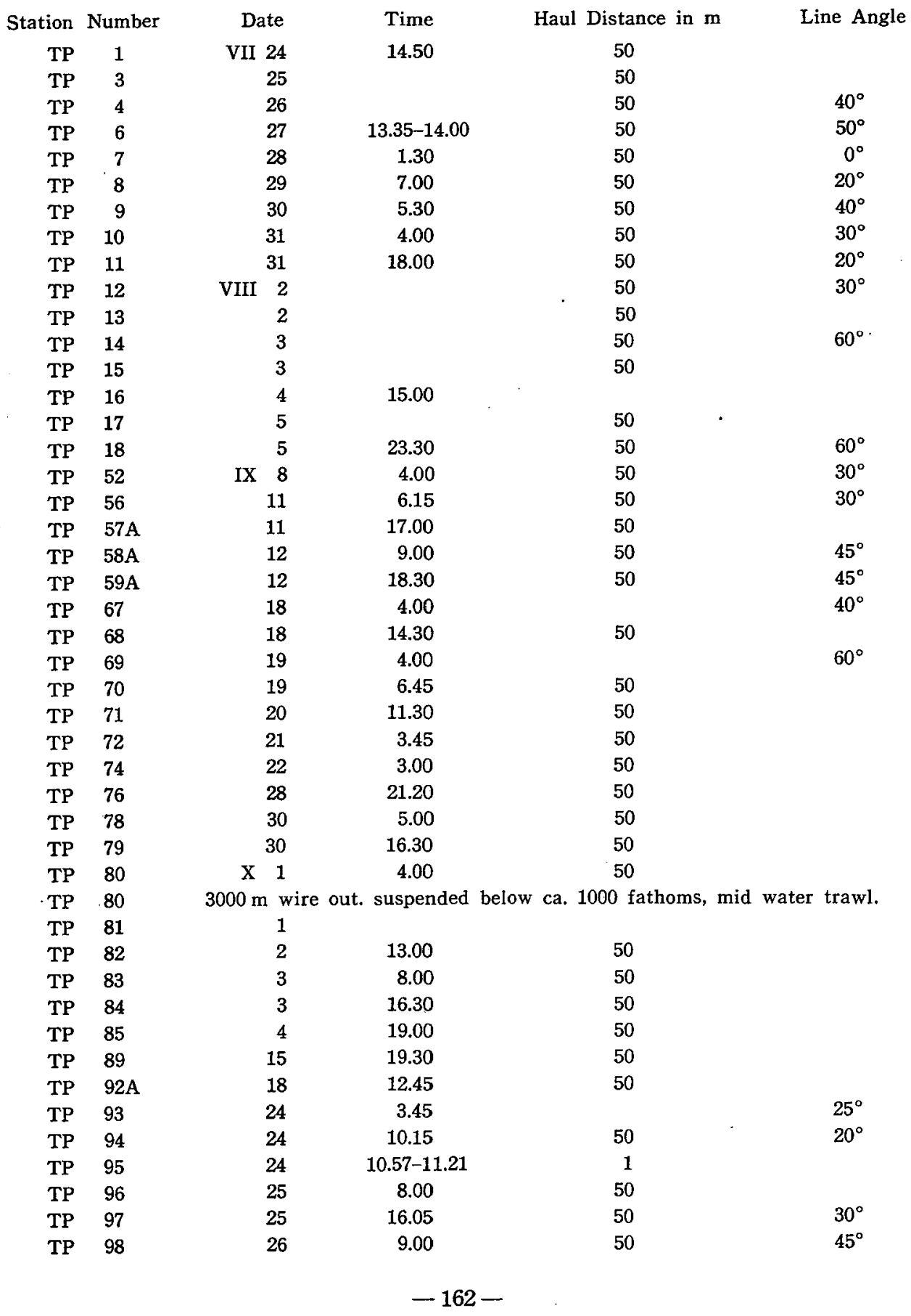




\begin{tabular}{|c|c|c|c|c|c|}
\hline $\mathrm{TP}$ & 99 & X 26 & 22.15 & 50 & \\
\hline $\mathrm{TP}$ & 99 & 27 & $10.06-12.10$ & Surface & \\
\hline $\mathrm{TP}$ & 100 & 29 & 0.45 & 50 & $60^{\circ}$ \\
\hline $\mathrm{TP}$ & 101 & 29 & 12.30 & 50 & \\
\hline $\mathrm{TP}$ & 102 & 30 & 6.30 & 50 & $50^{\circ}$ \\
\hline $\mathrm{TP}$ & 103 & 30 & 19.30 & 50 & $0^{\circ}$ \\
\hline $\mathrm{TP}$ & 104 & 31 & 9.45 & 50 & $30^{\circ}$ \\
\hline TP & 105 & 31 & 19.45 & 50 & $45^{\circ}$ \\
\hline $\mathrm{TP}$ & 106 & XI 1 & 14.45 & 50 & $45^{\circ}$ \\
\hline TP & 107 & 2 & 1,20 & & $40^{\circ}$ \\
\hline $\mathrm{TP}$ & 108 & 2 & 12.30 & 50 & $45^{\circ}$ \\
\hline TP & 109 & 3 & 1.00 & & $15^{\circ}$ \\
\hline TP & 111 & 3 & 22.15 & 50 & $30^{\circ}$ \\
\hline TP & 112 & 4 & 10.30 & 50 & $0^{\circ}$ \\
\hline TP & 113 & 5 & 3.30 & & $35^{\circ}$ \\
\hline TP & 114 & 5 & 19.30 & 50 & $45^{\circ}$ \\
\hline TP & 114 & 5 & $19.47-20.48$ & Surface & \\
\hline TP & 115 & 6 & 6.15 & & $75^{\circ}$ \\
\hline TP & 116 & 7 & 5.45 & 50 & $30^{\circ}$ \\
\hline TP & 117 & 7 & & 50 & \\
\hline TP & 118 & 8 & 10.30 & 50 & $60^{\circ}$ \\
\hline TP & 119 & 8 & & 50 & \\
\hline TP & 120 & 9 & 9.30 & 50 & \\
\hline TP & 121 & 10 & 0.15 & 50 & $15^{\circ}$ \\
\hline TP. & 122 & 10 & 13.30 & 50 & $30^{\circ}$ \\
\hline TP & 123 & 11 & 0.30 & & $15^{\circ}$ \\
\hline TP & 124 & 11 & 14.00 & 50 & $45^{\circ}$ \\
\hline TP & 125 & 12 & 4.00 & & $45^{\circ}$ \\
\hline $\begin{array}{l}\text { way, } \\
\text { inne }\end{array}$ & $\begin{array}{l}\text { off NE Reef } \\
\text { er side }\end{array}$ & 12 & 10.00 & Surface & \\
\hline TP & 126 & 13 & 2.30 & 50 & $45^{\circ}$ \\
\hline TP & 127 & 13 & 13.00 & 50 & $45^{\circ}$ \\
\hline TP & 128 & 14 & 2.15 & 50 & $45^{\circ}$ \\
\hline TP & 129 & 14 & 15.00 & 50 & $45^{\circ}$ \\
\hline TP & 130 & 15 & 8.00 & 50 & $60^{\circ}$ \\
\hline $\mathrm{TP}$ & 131 & 15 & 23.00 & & $55^{\circ}$ \\
\hline $\mathrm{TP}$ & 132 & 16 & 13.30 & 50 & $60^{\circ}$ \\
\hline TP & 133 & 17 & 4.00 & 50 & \\
\hline TP & 134 & 17 & 17.30 & 50 & $30^{\circ}$ \\
\hline $\mathrm{TP}$ & 135 & 18 & 8.00 & 50 & $50^{\circ}$ \\
\hline TP & 137 & 22 & $22.08-22.31$ & Surface & \\
\hline TP & 141 & 26 & $23.03-22.30$ & Surface & \\
\hline
\end{tabular}

Station data 2. For the plankton samples collected by a Japanese survey ship and presented to the Transpac Expedition.

Station Number

$\begin{array}{ll}\mathrm{J} & 1 \\ \mathrm{~J} & 2 \\ \mathrm{~J} & 3 \\ \mathrm{~J} & 4 \\ \mathrm{~J} & 5\end{array}$

Position

$40^{\circ} 50 \mathrm{~N} \times 142^{\circ} 05^{\prime} \mathrm{E}$
$40^{\circ} 52 \mathrm{~N} \times 142^{\circ} 57^{\prime} \mathrm{E}$
$40^{\circ} 53^{\prime} \mathrm{N} \times 143^{\circ} 53^{\prime} \mathrm{E}$
$40^{\circ} 49.5^{\prime} \mathrm{N} \times 145^{\circ} 13^{\prime} \mathrm{E}$
$40^{\circ} 07^{\prime} \mathrm{N} \times 145^{\circ} 09^{\prime} \mathrm{E}$

Date

Sept. 28, 1953

28

28

28

29
Haul Distance

$50 \mathrm{~m}$

50

50

50

50
Line Angle

$60^{\circ}$

$16^{\circ}$

$16^{\circ}$

$36^{\circ}$

$46^{\circ}$ 


\begin{tabular}{|c|c|c|c|c|c|c|c|}
\hline Station 1 & Number & & ositi & & Date & Haul Distance & Line Angle \\
\hline J & 6 & $39^{\circ} 32^{\prime} \mathrm{N}$ & $x$ & $145^{\circ} 05^{\prime} \mathrm{E}$ & Sept. 29 & $50 \mathrm{~m}$ & \\
\hline $\mathbf{J}$ & 7 & $39^{\circ} 37^{\prime} \mathrm{N}$ & $x$ & $143^{\circ} 58^{\prime} \mathrm{E}$ & 29 & 50 & $7^{\circ}$ \\
\hline $\mathrm{J}$ & 8 & $39^{\circ} 31^{\prime} \mathrm{N}$ & $x$ & $142^{\circ} 53 \mathrm{E}$ & 29 & 50 & $3^{\circ}$ \\
\hline$J$ & 9 & $39^{\circ} 28^{\prime} \mathrm{N}$ & $x$ & $142^{\circ} 20^{\prime} \mathrm{E}$ & 30 & 50 & $36^{\circ}$ \\
\hline $\mathrm{J}$ & 10 & $38^{\circ} 52^{\prime} \mathrm{N}$ & $x$ & $142^{\circ} 12^{\prime} \mathrm{E}$ & 30 & 50 & $0^{\circ}$ \\
\hline $\mathrm{J}$ & 11 & $38^{\circ} 10^{\prime} \mathrm{N}$ & $x$ & $141^{\circ} 47^{\prime} \mathrm{E}$ & 30 & 50 & $8^{\circ}$ \\
\hline $\mathrm{J}$ & 12 & $38^{\circ} 12^{\prime} \mathrm{N}$ & $x$ & $142^{\circ} 36^{\prime} \mathrm{E}$ & Oct. 3 & 50 & $20^{\circ}$ \\
\hline J & 13 & $38^{\circ} 14.5^{\prime} \mathrm{N}$ & $x$ & $144^{\circ} 03.5^{\prime} \mathrm{E}$ & 4 & 50 & $12^{\circ}$ \\
\hline $\mathbf{J}$ & 14 & $38^{\circ} 16^{\prime} \mathrm{N}$ & $x$ & $145^{\circ} 00^{\prime} \mathrm{E}$ & 4 & 50 & $14^{\circ}$ \\
\hline J & 15 & $37^{\circ} 30^{\prime} \mathrm{N}$ & $x$ & $145^{\circ} 05^{\prime} \mathrm{E}$ & 4 & 50 & $10^{\circ}$ \\
\hline J & 16 & $36^{\circ} 51^{\prime} \mathrm{N}$ & $x$ & $145^{\circ} 06^{\prime} \mathrm{E}$ & 4 & 50 & $14^{\circ}$ \\
\hline J & 17 & $36^{\circ} 38^{\prime} \mathrm{N}$ & $x$ & $143^{\circ} 37^{\prime} \mathrm{E}$ & 4 & 50 & $3^{\circ}$ \\
\hline $\mathrm{J}$ & 18 & $36^{\circ} 38^{\prime} \mathrm{N}$ & $x$ & $142^{\circ} 39^{\prime} \mathrm{E}$ & 5 & 55 & $34^{\circ}$ \\
\hline J & 19 & $36^{\circ} 20^{\prime} \mathrm{N}$ & & $141^{\circ} 12^{\prime} \mathrm{E}$ & 5 & 55 & $52^{\circ}$ \\
\hline
\end{tabular}

Station data 3. For the sampling stations during the Palao-New Guinea Cruises (March-May 1940).

Station Nu
2
3
4
5
6
7
8
9
10
11
12
13
15
52
53
54
55
56
57
58
59
60
61
62
63
64
65
66
67

Position
$6^{\circ} 19^{\prime} \mathrm{N} \times 134^{\circ} 27.7^{\prime} \mathrm{E}$
$5^{\circ} 40^{\prime} \mathrm{N} \times 134^{\circ} 26.4^{\prime} \mathrm{E}$
$5^{\circ} 01^{\prime} \mathrm{N} \times 134^{\circ} 25^{\prime} \mathrm{E}$
$4^{\circ} 30^{\prime} \mathrm{N} \times 134^{\circ} 31^{\prime} \mathrm{E}$
$3^{\circ} 58^{\prime} \mathrm{N} \times 134^{\circ} 38^{\prime} \mathrm{E}$
$3^{\circ} 27^{\prime} \mathrm{N} \times 134^{\circ} 37^{\prime} \mathrm{E}$
$2^{\circ} 58^{\prime} \mathrm{N} \times 134^{\circ} 39^{\prime} \mathrm{E}$
$2^{\circ} 29 \prime \mathrm{N} \times 134^{\circ} 35 \mathrm{E}$
$2^{\circ} 00^{\prime} \mathrm{N} \times 134^{\circ} 30^{\prime} \mathrm{E}$
$1^{\circ} 29^{\prime} \mathrm{N} \times 134^{\circ} 21^{\prime} \mathrm{E}$
$0^{\circ} 58^{\prime} \mathrm{N} \times 134^{\circ} 10^{\prime} \mathrm{E}$
$0^{\circ} 30^{\prime} \mathrm{N} \times 134^{\circ} 16^{\prime} \mathrm{E}$
$0.33^{\prime} \mathrm{S} \times 134^{\circ} 27^{\prime} \mathrm{E}$
$6^{\circ} 57.4^{\prime} \mathrm{N} \times 134^{\circ} 27.5^{\prime} \mathrm{E}$
$6^{\circ} 30^{\prime} \mathrm{N} \times 134^{\circ} 30^{\prime} \mathrm{E}$
$6^{\circ} 56.8^{\prime} \mathrm{N} \times 134^{\circ} 33.1^{\prime} \mathrm{E}$
$5^{\circ} 23.8^{\prime} \mathrm{N} \times 134^{\circ} 36.1^{\prime} \mathrm{E}$
$4^{\circ} 50.5^{\prime} \mathrm{N} \times 134^{\circ} 29.1^{\prime} \mathrm{E}$
$4^{\circ} 30^{\prime} \mathrm{N} \times 134^{\circ} 32.5^{\prime} \mathrm{E}$
$4^{\circ} 03^{\prime} \mathrm{N} \times 134^{\circ} 33.8^{\prime} \mathrm{E}$
$3^{\circ} 35.5^{\prime} \mathrm{N} \times 134^{\circ} 35.7^{\prime} \mathrm{E}$
$3^{\circ} 07.8^{\prime} \mathrm{N} \times 134^{\circ} 37.4^{\prime} \mathrm{E}$
$2^{\circ} 30^{\prime} \mathrm{N} \times 134^{\circ} 32.1^{\prime} \mathrm{E}$
$2^{\circ} 00.5^{\prime} \mathrm{N} \times 134^{\circ} 30.2^{\prime} \mathrm{E}$
$1^{\circ} 31.1^{\prime} \times 134^{\circ} 28.4^{\prime} \mathrm{E}$
$1^{\circ} 02^{\prime} \mathrm{N} \times 134^{\circ} 26.5^{\prime} \mathrm{E}$
$0^{\circ} 30.4^{\prime} \mathrm{N} \times 134^{\circ} 24.1^{\prime} \mathrm{E}$
$0^{\circ} 02.5^{\prime} \mathrm{N} \times 134^{\circ} 22^{\prime} \mathrm{E}$
$0^{\circ} 33^{\prime} \mathrm{S} \times 134^{\circ} 21^{\prime} \mathrm{E}$

Date

Mar. 17, 1940

18

18

18

18

19

19

19

19

20

20

20

21

May 20, 1940

20

21

21

21

21

21

22

22

22

22

23

23

23

23

24 
(No. 1)

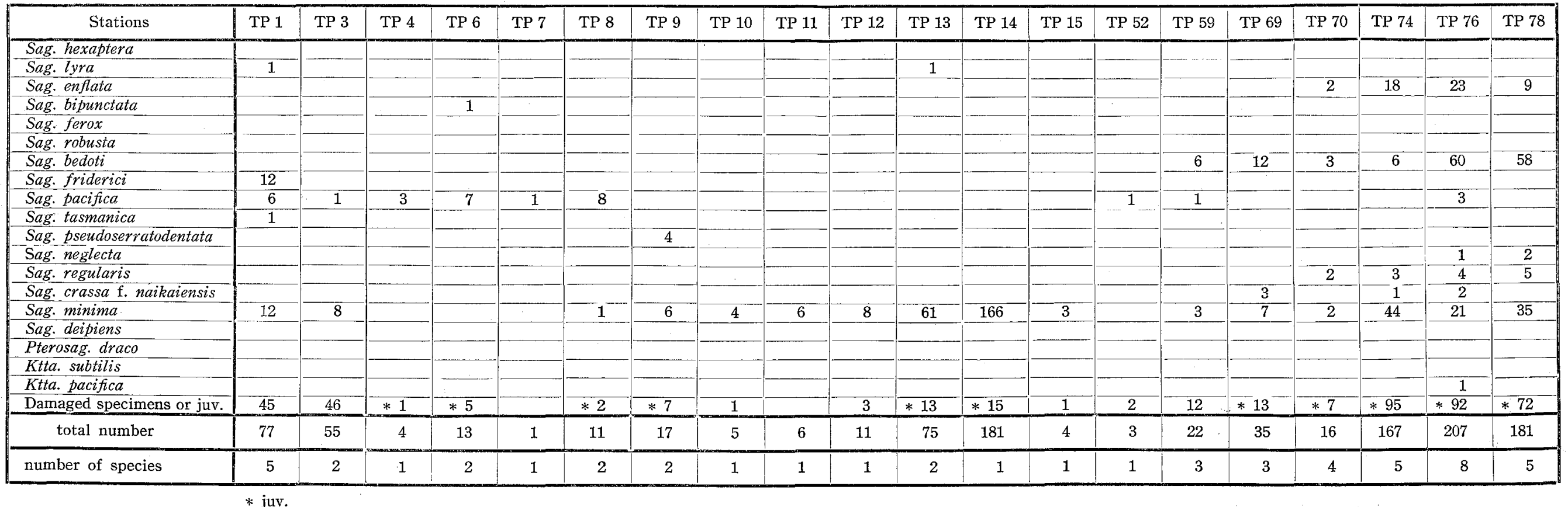

(No. 2)

\begin{tabular}{|c|c|c|c|c|c|c|c|c|c|c|c|c|c|c|c|c|c|c|c|c|}
\hline Stations & ТP 79 & TP 80 & TP 80 & TP 81 & TP 82 & TP 83 & TP 84 & TP 85 & TP 89 & TP 92 & TP 93 & TP 94 & TP 95 & TP 96 & TP 97 & TP 98 & TP 99 & TP 99 & $\begin{array}{c}\text { Entrance to } \\
\text { Yokosuka }\end{array}$ & TP 100 \\
\hline Sag. hexaptera & & & 1 & & $\bar{I}$ & & & & & & & & & & & & & & & 1 \\
\hline Sag. lyya & & & & & & & & & & & & & & & & & & & & \\
\hline Sag.enflata & 8 & 1 & 4 & 6 & 8 & 10 & & 1 & 8 & 24 & 58 & 7 & 24 & 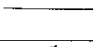 & 3 & 3 & 2 & 52 & & 4 \\
\hline Sag. bipunctata & & & & 1 & 1 & & 3 & & & & 1 & & 3 & 1 & 1 & & & 9 & & \\
\hline Sag. ferox & & & & & & & 1 & & & & & & & & & & & & & \\
\hline Sag. robusta & 1 & & & 1 & 1 & 4 & & & 1 & & & & 7 & & 1 & 1 & & 28 & & \\
\hline Sag. bedoti & & & & & & & & & & & 1 & & 2 & & & & & 2 & & \\
\hline Sag. friderici & & & & & & & & & & & & & & & & & & & & \\
\hline Sag. pacifica & 14 & 10 & 17 & 19 & 14 & 14 & 5 & 5 & 4 & & 4 & 4 & 27 & 3 & 1 & 7 & 3 & $\overline{41}$ & & 8 \\
\hline Sag. tasmanica & & & & & & & & & & & & & & & & & & & & \\
\hline Sag. pseudoserratodentata & & 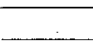 & & & & & & & & & & & & & & . & & & & \\
\hline Sag. neglecta & 2 & & & & & & & & & 1 & & & & 1 & & & & & & \\
\hline Sag. regularis & 8 & 2 & & 5 & 8 & 12 & 2 & 1 & 1 & & 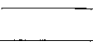 & 1 & 15 & & 3 & 4 & 1 & 7 & & 4 \\
\hline Sag. crassa f. naikaiensis & & & & & & & & & 1 & & & & & & & & & & 80 & \\
\hline Sag. minima & 1 & 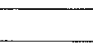 & & & 1 & & & & 1 & & 1 & & & & & & & & & 4 \\
\hline Sag. decipiens & & & & & & & & & & & & & & & & & & & & \\
\hline Pterosag. draco & 2 & - & 2 & & 1 & & & & 2 & 1 & 1 & & 4 & & & 1 & E & 15 & & 4 \\
\hline Ktta. subtilis & & & 3 & & & & & & & & & & & & & & & & & \\
\hline Ktta. pacifica & 2 & 2 & & 3 & 2 & 1 & & & 1 & 1 & & & 3 & 1 & 2 & 3 & 1 & 1 & & 1 \\
\hline Damaged specimens or juv. & 16 & 3 & 11 & 7 & 13 & 10 & 7 & 6 & $* 27$ & $* 68$ & $* 92$ & 18 & 21 & 11 & 12 & 1 & 10 & 20 & & 8 \\
\hline total number & 54 & 18 & 38 & 42 & 50 & 51 & 18 & 13 & 46 & 95 & 158 & 30 & 106 & 17 & 23 & 20 & 17 & 175 & 80 & 34 \\
\hline number of species & 8 & 4 & 5 & 6 & 9 & 5 & 4 & 3 & 8 & 4 & 6 & 3 & 8 & 4 & 6 & 6 & 4 & 8 & 1 & 7 \\
\hline
\end{tabular}

Appendix Table 1. Occurrence of chaetognaths in samples of the Transpac Expediton. (Nos. 1-2) 
(No. 3)

\begin{tabular}{|c|c|c|c|c|c|c|c|c|c|c|c|c|c|c|c|c|c|c|c|c|}
\hline Stations & TP 101 & TP 102 & TP 103 & TP 104 & TP 105 & TP 106 & TP 107 & TP 108 & TP 109 & TP 111 & TP 112 & TP 113 & TP 114 & TP 115 & TP 116 & TP 117 & TP 118 & TP 119 & TP 120 & TP 121 \\
\hline $\begin{array}{l}\text { Sag. hexaptera } \\
\text { Sag. lyra }\end{array}$ & & & & & & - & & & & & & & & & & & & 1 & & \\
\hline Sag. enflata & 4 & 4 & & 4 & 2 & 2 & & 1 & 5 & 1 & 1 & & 1 & & 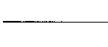 & & 1 & & 1 & \\
\hline Sag. bipunctata & 3 & 2 & 1 & 3 & & & & & & & & & & & & & & 1 & & \\
\hline Sag. ferox & & 1 & & & & & & & & & & & & & & & & & & \\
\hline Sag. robusta & - & & & & & 1 & & 1 & & & & & & & & & & & & \\
\hline $\begin{array}{l}\text { Sag. bedoti } \\
\text { Sax fridorici }\end{array}$ & E & 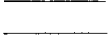 & & & & & & & & & & & & & & & & & & \\
\hline $\begin{array}{l}\text { Sag. friderici } \\
\text { Sag. pacifica }\end{array}$ & & & & & & & & & & & & & & & & & & & & \\
\hline$\frac{\text { Sag. pacifica }}{\text { Sag. tasmanica }}$ & 9 & 4 & 1 & 7 & 5 & 7 & 1 & 10 & 11 & 2 & & & 8 & 6 & 2 & 1 & 11 & 6 & 1 & 1 \\
\hline $\begin{array}{l}\text { Sag. tasmanica } \\
\text { Sag. pseudoserratodentata }\end{array}$ & & & & & & & & & & & & & & & & & & & & \\
\hline $\begin{array}{l}\text { Sag. pseudoserratodentata } \\
\text { Sag. neglecta }\end{array}$ & & & & & & 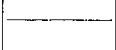 & & & & & & & & & & & 故 & & & \\
\hline Sag. regularis & 1 & 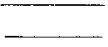 & & & & 2 & & 1 & 3 & & 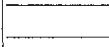 & & & & & & & & & \\
\hline $\begin{array}{l}\text { Sag. crassa f. naikaiensis } \\
\text { Sag, minima }\end{array}$ & 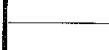 & 1 & & 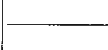 & $?$ & & & 1 & 6 & 3 & 14 & 5 & & & 3 & & 1 & . & & \\
\hline Sag. decipiens & & & & & & & & & & & & & & & & & & & & \\
\hline Pterosag. draco & 2 & 2 & - & & & 1 & & 2 & 4 & 1 & & & & & & 1 & 2 & & & 2 \\
\hline Ktta. subtilis & & & & & 1 & & & & & & & & & & & & & & & \\
\hline Ktta. pacifica & 2 & & & 2 & & $\frac{2}{a}$ & & & 4 & 1 & & & & & & & & & & \\
\hline Damaged specimens or juv. & 6 & 5 & 2 & 4 & 4 & 6 & & $* 37$ & $* 48$ & 5 & 8 & 3 & & & 1 & 2 & 7 & 5 & 3 & 2 \\
\hline total number & 27 & 19 & 4 & 20 & 14 & 21 & 1 & 53 & 81 & 13 & 23 & 8 & 9 & 6 & 6 & 4 & 22 & 13 & 5 & 5 \\
\hline number of species & 6 & 6 & 2 & 4 & 4 & 6 & 1 & 6 & 6 & 5 & 2 & 1 & 2 & 1 & 2 & 2 & 4 & 3 & 2 & 2 \\
\hline
\end{tabular}

(No. 4)

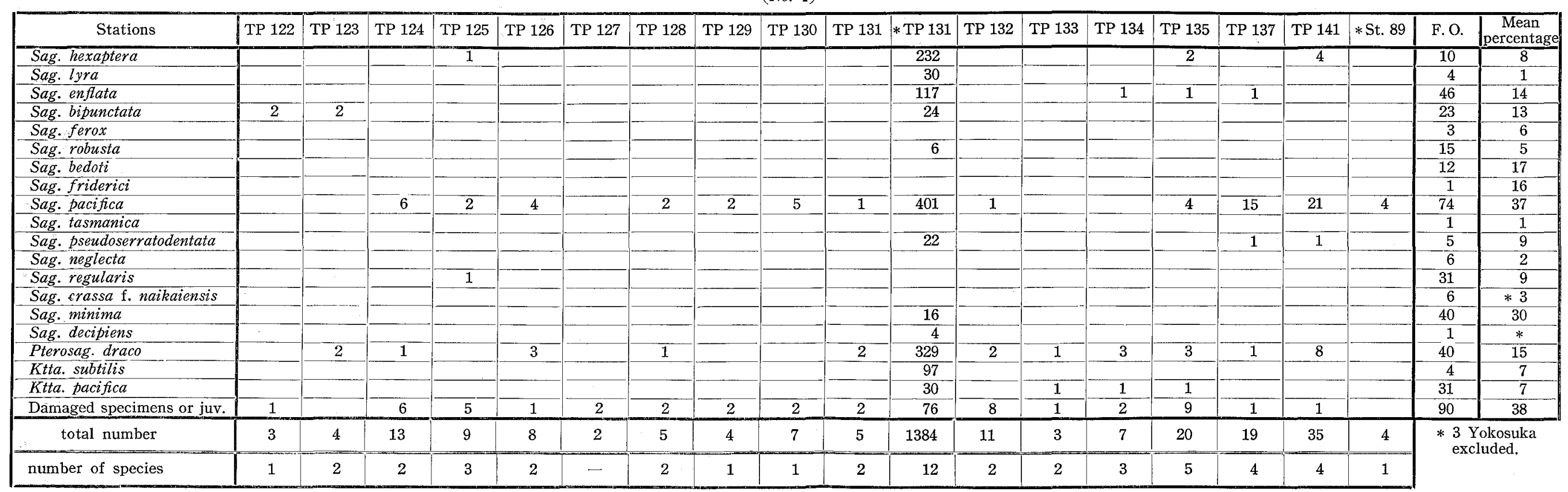

* TP 131 large net hauled from $450 \mathrm{~m} . \quad$ * St. 89 Stranger: North Pacific 5509-2nd, 23.00 .

Appendix Table 1 (contintued). Occurrence of chaetognaths in samples of the Transpac Expedition. (Nos. 3-4) 
(No. 1)

\begin{tabular}{|c|c|c|c|c|c|c|c|c|c|c|c|c|c|c|c|c|c|c|c|c|c|}
\hline Stations & TP 19 & TP 20 & TP 21 & TP 22 & TP 23 & TP 24 & TP 25 & TP 26 & TP 27 & TP 28 & TP 29 & TP 30 & TP 31 & TP 32 & TP 33 & TP 34 & TP 35 & TP 36 & TP 37 & TP 38 & TP 39 \\
\hline Situation & \begin{tabular}{|c}
$48-14.2$ \\
$\mathrm{~N}$ \\
$153-20.1$ \\
$\mathrm{~W}$
\end{tabular} & $\begin{array}{c}49-29.5 \\
\mathrm{~N} \\
154-56.5 \\
\mathrm{~W}\end{array}$ & $\begin{array}{c}50-25.0 \\
\mathrm{~N} \\
156-37.0 \\
\mathrm{w}\end{array}$ & $\begin{array}{c}51-21.3 \\
\mathrm{~N} \\
158-20.0 \\
\mathrm{~W} \\
\end{array}$ & $\begin{array}{c}52-10.4 \\
\mathrm{~N} \\
160-0.80 \\
\mathrm{~W}\end{array}$ & $\begin{array}{c}53-15.0 \\
\mathrm{~N} \\
161-55.0 \\
\mathrm{~W} \\
\end{array}$ & \begin{tabular}{|c}
$53-32.5$ \\
$\mathrm{~N}$ \\
$163-20.8$ \\
$\mathrm{~W}$ \\
\end{tabular} & $\begin{array}{c}54-00.0 \\
\mathrm{~N} \\
168-19.8 \\
\mathrm{~W} \\
\end{array}$ & $\begin{array}{c}54-00.0 \\
\mathrm{~N} \\
170-03.0 \\
\mathrm{~W}\end{array}$ & $\begin{array}{c}53-59.5 \\
\mathrm{~N} \\
171-40.0 \\
\mathrm{~W}\end{array}$ & $\begin{array}{c}54-00.0 \\
\mathrm{~N} \\
173-15.5 \\
\mathrm{~W} \\
\end{array}$ & \begin{tabular}{|c}
$53-57.7$ \\
$\mathrm{~N}$ \\
$\mathrm{~N}-04.5$ \\
$\mathrm{~W}$
\end{tabular} & $\begin{array}{c}53-15.6 \\
\mathrm{~N} \\
\mathrm{~N}-37.6 \\
\mathrm{~W} \\
\end{array}$ & 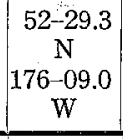 & $\begin{array}{c}52-19.9 \\
\mathrm{~N} \\
176-57.5 \\
\mathrm{~W}\end{array}$ & $\begin{array}{c}53-10.3 \\
N \\
177-59.0 \\
W\end{array}$ & $\begin{array}{c}54-05.5 \\
\mathrm{~N} \\
\mathrm{~N} \\
\mathrm{~W} \\
\mathrm{~W}\end{array}$ & \begin{tabular}{|c|}
$54-00.9$ \\
$\mathrm{~N}$ \\
$178-58.7$ \\
$\mathrm{E}$
\end{tabular} & $\begin{array}{c}53-59.0 \\
\mathrm{~N} \\
176-55.0 \\
\mathrm{E}\end{array}$ & $\begin{array}{c}53-59.1 \\
N \\
174-49.0 \\
E\end{array}$ & $\begin{array}{c}54-03.1 \\
\mathrm{~N} \\
172-28.8 \\
\mathrm{E} \\
\end{array}$ \\
\hline Date & Aug. 6 & Aug. 7 & Aug. 8 & Aug. 8 & & Aug. 9 & Aug. 10 & Aug. 12 & Aug. 13 & & & & Aug. 15 & Aug. 15 & Aug. 24 & Aug. 25 & $\mid$ Aug. $25 \mid$ & Aug. 26 & Aug. 27 & Aug. 28 & Aug. 29 \\
\hline Time & & 9.00 & & 12.00 & & & & 11.30 & 10.30 & & 6.45 & & & & 20,00 & 10.00 & 18.30 & 10.30 & & 13.30 & 3.15 \\
\hline Haul distance (m.) & $0-50$ & $0-50$ & & $0-50$ & * & $0-50$ & & $0-50$ & & $0-50$ & $0-50$ & & $0-50$ & $0-50$ & $0-50$ & $0-50$ & $0-50$ & $0-50$ & & $0-50$ & $0-50$ \\
\hline Rope angle & & & & $45^{\circ}$ & & & $50^{\circ}$ & & $40^{\circ}$ & & & & $20^{\circ}$ & $0^{\circ}$ & $45^{\circ}$ & $60^{\circ}$ & $60^{\circ}$ & $60^{\circ}$ & $70^{\circ}$ & $60^{\circ}$ & $60^{\circ}$ \\
\hline Sag. elegans & 2 & 6 & 5 & 10 & 23 & 9 & 2 & 6 & 11 & 4 & 8 & 2 & 9 & 2 & 3 & 22 & 21 & 82 & 26 & 17 & 15 \\
\hline Eukr. hamata & & 1 & 1 & & & & & & & & & & & & & & & & & & \\
\hline \multicolumn{22}{|c|}{ Damaged specimens or juv. } \\
\hline total number & 2 & 7 & 6 & 10 & 23 & 9 & 2 & 6 & 11 & 4 & 8 & 2 & 9 & 2 & 3 & 22 & 21 & 82 & 26 & 17 & 15 \\
\hline
\end{tabular}

(No. 2)

\begin{tabular}{|c|c|c|c|c|c|c|c|c|c|c|c|c|c|c|c|c|c|c|c|c|c|}
\hline Stations & TP 40 & TP 41 & TP 42 & TP 43 & TP 44 & TP 45 & TP 46 & TP 47 & TP 48 & TP 49 & TP 50 & TP 51 & TP 53 & TP 55 & TP 61 & TP 63 & TP 64 & TP 65 & TP 66 & TP 73 & \\
\hline Situation & $\begin{array}{c}53-57.0 \\
N \\
171-10.8 \\
E\end{array}$ & $\begin{array}{c}53-32.1 \\
\mathrm{~N} \\
168-50.8 \\
\mathrm{E}\end{array}$ & \begin{tabular}{|c|c}
$53-32.4$ \\
$N$ \\
$166-10.8$ \\
$E$
\end{tabular} & \begin{tabular}{|c|}
$53-35.5$ \\
$\mathrm{~N}$ \\
$163-42.0$ \\
$\mathrm{E}$
\end{tabular} & \begin{tabular}{|c|}
$53-40.8$ \\
$\mathrm{~N}$ \\
$161-55.5$ \\
$\mathrm{E}$
\end{tabular} & $\begin{array}{c}52-23.0 \\
\mathrm{~N} \\
163-15.2 \\
\mathrm{E}\end{array}$ & \begin{tabular}{|c|}
$51-13.0$ \\
$\mathrm{~N}$ \\
$164-34.3$ \\
$\mathrm{E}$
\end{tabular} & \begin{tabular}{|c|}
$49-50.1$ \\
$\mathrm{~N}$ \\
$165-49.2$ \\
$\mathrm{E}$
\end{tabular} & \begin{tabular}{|c|}
$48-46.3$ \\
$N$ \\
$166-48.1$ \\
$\mathrm{E}$
\end{tabular} & $\begin{array}{c}47-35.7 \\
\mathrm{~N} \\
167-44.8 \\
\mathrm{E}\end{array}$ & \begin{tabular}{|c|}
$46-16.5$ \\
$N$ \\
$168-52.2$ \\
$E$
\end{tabular} & \begin{tabular}{|c|}
$45-05.5$ \\
N \\
$170-08.5$ \\
$E$
\end{tabular} & \begin{tabular}{|c}
$42-07.9$ \\
$\mathrm{~N}$ \\
$169-28.1$ \\
$\mathrm{E}$
\end{tabular} & \begin{tabular}{|c|}
$41-19.0$ \\
$\mathrm{~N}$ \\
$168-20.2$ \\
$\mathrm{E}$
\end{tabular} & \begin{tabular}{|c|}
$45-15.1$ \\
$\mathrm{~N}$ \\
$158-20.0$ \\
$\mathrm{E}$
\end{tabular} & \begin{tabular}{|c|}
$46-23.5$ \\
$\mathrm{~N}$ \\
$155-28.6$ \\
$\mathrm{E}$
\end{tabular} & $\mid \begin{array}{c}46-54.5 \\
N \\
N \\
153-55.2 \\
E\end{array}$ & $\left|\begin{array}{c}45-29.9 \\
\mathrm{~N} \\
154-19.7 \\
\mathrm{E}\end{array}\right|$ & $\left|\begin{array}{c}44-09.0 \\
\mathrm{~N} \\
152-56.8 \\
\mathrm{E}\end{array}\right|$ & \begin{tabular}{|c|}
$40-53.4$ \\
N \\
$143-51.5$ \\
$E$
\end{tabular} & \\
\hline Date & Aug. 30 & & Sep. 1 & Sep. 1 & Sep. 2 & Sep. 3 & Sep. 3 & Sep. 4 & Sep. 5 & Sep. 6 & Sep. 6 & Sep. 7 & Sep. 8 & Sep. 10 & Sep. 14 & Sep. 15 & Sep. 15 & Sep. 16 & Sep. 17 & Sep. 21 & \\
\hline Time & 12.45 & & 6.00 & 23.00 & 5.00 & 8.15 & 19.00 & 17.30 & 11.00 & & 14.45 & 11.15 & 15.25 & 6.45 & 9.00 & 5.45 & 20.45 & 10.30 & 9.00 & 4.30 & \\
\hline Haul distance (m.) & $0-50$ & & $0-50$ & & $0-50$ & & $0-50$ & $0-50$ & $0-50$ & & $0-50$ & $0-50$ & $0-50$ & $0-50$ & $0-50$ & $0-50$ & $0-50$ & $0-50$ & $0-50$ & $0-50$ & \\
\hline Rope angle & $45^{\circ}$ & $15^{\circ}$ & & $40^{\circ}$ & . & $40^{\circ}$ & & & & $40^{\circ}$ & & $30^{\circ}$ & $30^{\circ}$ & & $45^{\circ}$ & $60^{\circ}$ & $45^{\circ}$ & $10^{\circ}$ & & & F.O. \\
\hline Sag. elegans & 6 & 2 & 6 & 1 & 7 & 1 & 1 & 1 & 2 & 10 & 3 & & 5 & & 2 & 6 & 4 & 3 & $* 4$ & 2 & 95 \\
\hline Eukr. hamata & & & & & & & & & & & & & & & & & & & & & 5 \\
\hline Damaged specimens or juv. & & & & & & 5 & & 1 & & & 1 & 1 & 1 & 1 & & & & & & 1 & 17 \\
\hline total number & 6 & 2 & 6 & 1 & 7 & 6 & 1 & 2 & 2 & 10 & 4 & 1 & 6 & 1 & 2 & 6 & 4 & 3 & 4 & 3 & \\
\hline
\end{tabular}

Appendix Table 2. Chatognaths occurred in the elegans-water during the Transpac Expedition. (Nos. 1-2) 


\begin{tabular}{|c|c|c|c|c|c|c|c|c|c|}
\hline \multirow{2}{*}{$\frac{7}{\mathrm{TP} 18}$} & \multicolumn{3}{|c|}{ West of $170^{\circ} \mathrm{E}$} & \multicolumn{4}{|c|}{ West of $150^{\circ} \mathrm{E}$} & \multirow[b]{2}{*}{ F. O. } & \multirow[b]{2}{*}{ pi } \\
\hline & TP 56 & TP 67 & TP 68 & $\mathrm{TP} 71$ & $\mathrm{~J} 3$ & J 4 & J 10 & & \\
\hline \multirow[t]{2}{*}{1} & & & & & & & & 30 & \\
\hline & 1 & & & & & & 1 & $\rightarrow 20$ & \\
\hline \multirow[t]{4}{*}{3} & 3 & $y$ & 9 & 6 & 5 & 1 & 1 & 100 & \\
\hline & & & & 3 & 1 & & 2 & 30 & \\
\hline & & & & 2 & & & 1 & 20 & \\
\hline & & 3 & 2 & 3 & & 1 & 2 & 60 & \\
\hline 4 & & 1 & & 14 & & & 1 & 60 & \\
\hline 8 & 4 & 13 & 11 & 28 & 6 & 2 & 8 & & \\
\hline 2 & 2 & 2 & 2 & 4 & 2 & 2 & 5 & & \\
\hline
\end{tabular}

tognaths occurred in samples from the northern mixing area of the elegans-water and the warm water.

\begin{tabular}{|c|c|c|c|c|c|c|c|c|c|c|c|c|c|}
\hline J 6 & J 7 & $\mathrm{~J} 8$ & J 9 & J 11 & J 12 & $\mathrm{~J} 13$ & $\mathrm{~J} 14$ & $\mathrm{~J} 15$ & $\mathrm{~J} 16$ & J 17 & J 18 & J 19 & F. O. \\
\hline \multirow[t]{3}{*}{3} & 6 & & & 1 & 2 & 2 & 2 & 2 & & & 3 & 12 & $6 y$ \\
\hline & & & & & & & 1 & & & & & & 13 \\
\hline & & & & & & & & & & & 1 & 2 & 13 \\
\hline 1 & 18 & 1 & 4 & 9 & 1 & & & & & & & 17 & 63 \\
\hline \multirow[t]{2}{*}{1} & 1 & & & & & 1 & 2 & 3 & & 2 & & 1 & 63 \\
\hline & 1 & & & & 2 & & & & & & & & 13 \\
\hline \multirow[t]{2}{*}{1} & 1 & & & & 2 & 3 & 2 & 3 & 2 & . & 1 & 1 & 69 \\
\hline & & & & 1 & & & & & & & & & 13 \\
\hline 15 & 2 & & 6 & 3 & 9 & 3 & 1 & & & & & 9 & 69 \\
\hline 16 & 84 & 2 & 6 & 26 & 28 & 13 & 15 & & 1 & 3 & 2 & 30 & 88 \\
\hline 37 & 113 & 3 & 16 & 40 & 44 & 22 & 23 & 8 & 3 & 5 & 7 & 72 & · \\
\hline 5 & 6 & 1 & 2 & 4 & 5 & 4 & 5 & 3 & 1 & 1 & 3 & 6 & \\
\hline
\end{tabular}

5able 4. Chaetognaths occurred in samples from the North-Eastern waters of Japan. 
(No. 1)

\begin{tabular}{|c|c|c|c|c|c|c|c|c|c|c|c|c|c|c|c|c|c|c|c|c|c|c|c|c|c|c|c|c|c|c|}
\hline Stations & & MP 1 & & & & & & & & MP 3 & & & & & & MP 5 & & Ml & & & $\mathrm{M}$ & 88 & & & & & MP 10 & & & \\
\hline number of jar & $\mathrm{J} 1$ & $\mathrm{~J} 2$ & $\mathrm{~J} 3$ & $\mathrm{~J} 4$ & $\mathrm{~J} 6$ & $\mathrm{~J} 7$ & $\mathrm{~J} 8$ & $\mathrm{~J} 9$ & $\mathrm{~J} 10$ & $\mathrm{~J} 11$ & $\mathrm{~J} 12$ & $\mathrm{~J} 12$ & $\mathrm{~J} 14$ & $\mathrm{~J} 15$ & $\mathrm{~J} 16$ & $\mathrm{~J} 18$ & $\mathrm{~J} 21$ & $\mathrm{~J} 23$ & $\mathrm{~J} 25$ & $\mathrm{~J} 26$ & $\mathrm{~J} 28$ & $\mathrm{~J} 30$ & $\mathrm{~J} 30$ & $\mathrm{~J} 32$ & $\mathrm{~J} 33$ & $\mathrm{~J} 34$ & J 35 & $\mathrm{~J} 37$ & $\mathrm{~J} 38$ & $\mathrm{~J} 39$ \\
\hline Sag. hexaptera & & & 3 & & 2 & & & & & 1 & & 2 & 5 & & & 1 & 2 & 47 & 4 & 23 & & & 1 & 37 & 2 & 62 & $\overline{12}$ & & 7 & 5 \\
\hline Sag. enflata & 1 & 3 & & 4 & 4 & 1 & & 6 & 2 & 47. & 17 & 36 & 61 & 5 & & 10 & 12 & 103 & 25 & 218 & & 15 & 16 & 18 & 1 & 41 & 25 & 10 & 13 & 13 \\
\hline Sag. bipunctata & & & & & & & & & & & & & 1 & & & & & & & 1 & & & & & & & & & 1 & \\
\hline $\begin{array}{l}\text { Sag. ferox } \\
\text { Sag. robusta }\end{array}$ & & & 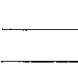 & & & & & & & & & 1 & - & & 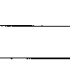 & 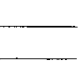 & $* 1$ & & 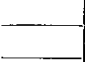 & - & & 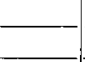 & & 3 & & & . & 23 & 7 & 17 \\
\hline Sag. pulchra & & & & & & & & & & & & & & & & & & & & $\pi$ & & & & & & & & & & \\
\hline Sag. pacifica & $* 106$ & $* 134$ & 71 & 5 & 5 & - & & 27 & 45 & 2 & 3 & 34 & 51 & $\frac{11}{2}$ & & & 1 & 5 & 2 & 74 & & & 5 & 65 & 1 & 30 & 101 & 54 & 30 & 31 \\
\hline Sag. pseudoserratodentata & 23 & 29 & 6 & & & & & & & & & 1 & 1 & 2 & & & & & & & & & & & & & & & 1 & \\
\hline Sag. neglecta & & & & & & & & & & & & & & & & & & & & & & & & & & & & & & \\
\hline Sag. regularis & & & & & & & & 1 & & & & & - & & & & & & $\ldots$ & 1 & & 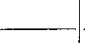 & - & 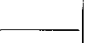 & - & & 1 & & & \\
\hline Sag. minima & 60 & 95 & 7 & 3 & & & & & & & & & - & & & & & & 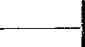 & 1 & & $\ldots$ & & & & & & & 1 & \\
\hline Sag. planctonis & & & & & & & & & & & - & & & & & & & W & . & & & & & $\ldots$ & - & & - & - & - & 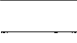 \\
\hline $\begin{array}{l}\text { Sag. mäcrocephala } \\
\text { Pteross draco }\end{array}$ & 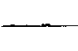 & & 3 & & & - & & 3 & & 23 & $\begin{array}{ll}9 \\
\end{array}$ & 8 & 12 & 4 & & 1 & & 13 & 1 & 12 & & & & 283 & 14 & 283 & 170 & 31 & 24 & 55 \\
\hline $\begin{array}{l}\text { Tterosag. araco } \\
\text { Ktta. subtilis }\end{array}$ & -2 & 1 & & 2 & 4 & & & & 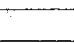 & 1 & 1 & & 12 & & & & & & & 1 & & & & 4 & & $\frac{200}{2}$ & & & 1 & 55 \\
\hline Ktta. pacifica & 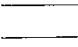 & & - & & & E. & 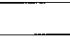 & & . & & & & & 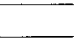 & & & & & & & & & & & & 1 & & & & 1 \\
\hline $\begin{array}{l}\text { Eukr. hamata } \\
\text { Damaged specimens or juv. }\end{array}$ & 16 & 16 & 31 & 3 & 17. & & & 7 & 7 & 1 & 3 & 20 & 34 & 3 & & 25 & 22 & 16 & $\frac{1}{11}$ & 60 & 3 & 3 & 8 & 10 & 6 & $* 47$ & 10 & 12 & 46 & $\frac{1}{6}$ \\
\hline total number & 208 & 278 & 121 & 17 & 32 & 1 & 0 & 44 & 54 & 75 & 33 & 102 & 177 & 25 & 0 & 37 & 38 & 184 & 44 & 390 & 3 & 18 & 30 & 420 & 24 & 466 & 319 & 130 & 131 & 129 \\
\hline number of species & 5 & 5 & 5 & 4 & 4 & 1 & 0 & 4 & 2 & 5 & 4 & 6 & 7 & 4 & 0 & 3 & 4 & 4 & 5 & 7 & - & 1 & 3 & 6 & 4 & 6 & 5 & 4 & 9 & 7 \\
\hline
\end{tabular}

(No. 2)

\begin{tabular}{|c|c|c|c|c|c|c|c|c|c|c|c|c|c|c|c|c|c|c|c|c|c|c|c|c|c|c|c|c|}
\hline \multirow{2}{*}{$\begin{array}{r}\text { Stations } \\
\text { number of jar }\end{array}$} & \multicolumn{5}{|c|}{ MP 12} & \multirow{2}{*}{\begin{tabular}{|c|} 
MP 14 \\
J 46
\end{tabular}} & \multirow{2}{*}{$\frac{\text { MP } 15}{\mathrm{~J} 47}$} & \multicolumn{2}{|c|}{ MP 16} & \multicolumn{2}{|c|}{ MP 17} & \multicolumn{4}{|c|}{ MP 18} & \multicolumn{6}{|c|}{ MP 20} & \multirow{2}{*}{$\frac{\text { MP } 35}{\text { J } 69}$} & \multicolumn{2}{|c|}{ MP 36} & \multicolumn{2}{|c|}{ MP 41} & \multirow{2}{*}{ F.O. } & \multirow{2}{*}{$\begin{array}{c}\text { Mean } \\
\text { percentage }\end{array}$} \\
\hline & $\mathrm{J} 40$ & $\mathrm{~J} 41$ & J 42 & $\mathrm{~J} 43$ & J 44 & & & $\mathrm{~J} 48$ & $\mathrm{~J} 50$ & J 51 & J 52 & J 55 & J 56 & $\mathrm{~J} 57$ & J 57 & J 62 & $\mathrm{~J} 64$ & J 64 & J 65 & $\mathrm{~J} 66$ & J 67 & & $\mathrm{~J} 70$ & J 71 & $\mathrm{~J} 73$ & J 74 & & \\
\hline Sag. hexaptera & 1 & 4 & & & 15 & 45 & 1 & 244 & 23 & & & 5 & 3 & 3 & 19 & 6 & 1 & 16 & 28 & 7 & 24 & 1 & 24 & 25 & 6 & 4 & 68 & 11 \\
\hline Sag. enflata & 22 & 12 & & 3 & 49 & 384 & 19 & 30 & & & & 1 & 2 & & 4 & 2 & & 14 & 29 & 7 & 21 & 4 & 20 & 26 & 20 & 12 & 81 & 24 \\
\hline Sag. bipunctata & 2 & & & & & & & 3 & & & & & & & & & & 1 & & 1 & & 2 & & 1 & 1 & 1 & 19 & 1 \\
\hline Sag. ferox & $\frac{2}{16}$ & 1 & & & & & & & . & & & - & - & & & & & & & 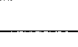 & & & & & & & 4 & 2 \\
\hline Sag. robusta & 16 & 2 & & 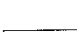 & 15 & 1 & & & & & 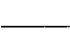 & 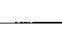 & & 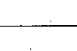 & 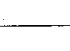 & & & 2 & & & 2 & & 2 & & & - & $\frac{21}{2}$ & 3 \\
\hline $\begin{array}{l}\text { Sag. pulchra } \\
\text { Sag. pacifica }\end{array}$ & 10 & 2 & & 3 & 140 & 8 & 7 & 48 & 2 & 5 & & 13 & 10 & 33 & 43 & 17 & 4 & 48 & 61 & 42 & 93 & 16 & 41 & 61 & 30 & 26 & $\frac{2}{84}$ & $\frac{*}{30}$ \\
\hline $\begin{array}{l}\text { Sag. pactica } \\
\text { Sag. pseudoserratodentata }\end{array}$ & & & & & 1. & & & 1 & & & & & & 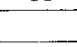 & 7 & 4 & & 1 & 4 & & 3 & & 1 & & & 1 & 28 & $\frac{5}{4}$ \\
\hline Sag. neglecta & - & & & 1 & & & & & 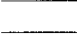 & & & & & & & & & & & & & & & 2 & & & 4 & 6 \\
\hline Sag. regularis & & 1 & & & & & - & & & & & & & & & & & 1 & & 2 & & & 2 & & 1 & 2 & 14 & 1 \\
\hline Sag. minima & & & & & & & & 1 & & & & & & & & 1 & & & & 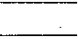 & & & & & & & 14 & 11 \\
\hline Sag. planctonis & & & & & 1 & & & & & - & & & & & & & & & & & & & & & & & 2 & $*$ \\
\hline Sag. macrocephala & & & & & & & 1 & & & & & & & & & & & & & & & & & & & & 2 & 3 \\
\hline Pterosag. draco & 29 & 25 & 2 & 1 & 154 & 52 & & 104 & 2 & 1 & & 1 & 2 & & 11 & 4 & & 17 & 35 & 22 & 19 & 4 & 12 & 15 & 18 & 6 & 70 & 21 \\
\hline Ktta. subtilizs & & & & & 2 & 1 & & 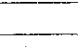 & 2 & & & & & 1 & 2 & & & & & 2 & 1 & & 2 & 2 & & & 35 & 3 \\
\hline Ktta. pacifica & 1 & & & - & 1 & & & - & & $\ldots$ & - & & - & - & 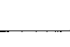 & 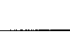 & 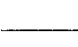 & 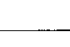 & - & - & 2 & 2 & & & & & 11 & 1 \\
\hline $\begin{array}{l}\text { Eukr. hamata } \\
\text { Damaged spécimens or juv. }\end{array}$ & 52 & 15 & & 3 & 36 & 125 & 2 & 39 & 4 & 1 & & 1 & 5 & 35 & 34 & 12 & 3 & 64 & 11 & 52 & 37 & 15 & 34 & 49 & 38 & 25 & $\begin{array}{r}4 \\
89\end{array}$ & $\frac{2}{23}$ \\
\hline total number & 135 & 62 & 2 & 11 & 414 & 616 & 30 & 470 & 33 & 7 & 0 & 21 & 22 & 72 & 120 & 46 & 8 & 164 & 168 & 135 & 202 & 44 & 138 & 181 & 114 & 77 & & \\
\hline number of species & 8 & 7 & 1 & 4 & 9 & 6 & 4 & 7 & 4 & 2 & 0 & 4 & 4 & 3 & 6 & 6 & 2 & 8 & 5 & 7 & 8 & 7 & 8 & 7 & 6 & 7 & & \\
\hline
\end{tabular}




\begin{tabular}{|c|c|c|c|c|c|c|c|c|c|c|c|c|c|c|c|c|c|c|c|c|c|c|c|c|c|}
\hline Stations & $\mathrm{S}_{1}^{\mathrm{SB}_{3}}$ & $\begin{array}{c}\mathrm{S}_{5} \mathrm{~B} \\
\end{array}$ & $\begin{array}{c}\mathrm{SB} B \\
10\end{array}$ & $\begin{array}{l}\text { S B } \\
15\end{array}$ & $\begin{array}{l}\text { S B } \\
20\end{array}$ & $\underset{25}{\mathrm{SBB}}$ & $\underset{30}{\text { S B }}$ & $\begin{array}{l}\text { S B } \\
35\end{array}$ & $\underset{40}{\text { S B }}$ & $\underset{44}{\mathrm{~S} \mathrm{~B}_{4}}$ & $\begin{array}{l}\mathrm{SB} \\
50\end{array}$ & $\begin{array}{l}\text { S B } \\
55\end{array}$ & $\begin{array}{c}\mathrm{SB} \\
60\end{array}$ & $\begin{array}{l}\mathrm{SB} \\
64\end{array}$ & $\begin{array}{l}\text { S B } \\
68\end{array}$ & $\begin{array}{l}\mathrm{SB} \\
71\end{array}$ & \begin{tabular}{l|}
$\mathrm{SB} B$ \\
75
\end{tabular} & $\underset{80}{\mathrm{SBB}}$ & $\begin{array}{l}55 \\
85\end{array}$ & $\begin{array}{l}\mathrm{SB} B \\
90\end{array}$ & $\mathrm{~S}_{95}$ & $\begin{array}{l}\mathrm{S} B \\
100\end{array}$ & $\begin{array}{l}S B \\
105\end{array}$ & $\begin{array}{l}\text { S B } \\
109\end{array}$ & $\begin{array}{l}\text { S B } \\
112\end{array}$ \\
\hline Sag. hexaptera & 4 & 18 & 13 & 11 & 63 & 25 & 16 & 65 & 209 & 140 & 30 & 141 & 109 & 21 & 18 & 31 & 25 & 20 & 149 & 56 & 168 & 44 & 101 & 70 & 65 \\
\hline Sag. lyra & 41 & 2 & & & 14 & 5 & 14 & 14 & 171 & 29 & 4 & 11 & & & & & & $\overline{9}$ & 4 & 33 & 11 & 49 & 13 & 7 & 15 \\
\hline Sag. enflata & $\overline{33}$ & 12 & 105 & 460 & 694 & 616 & 182 & 285 & 160 & 391 & 54 & 408 & 204 & 109 & 179 & 43 & 69 & 526 & 408 & 773 & 597 & 927 & 723 & 188 & 721 \\
\hline Sag. bipunctata & 13 & & 28 & & 14 & 4 & & & & & & 1 & 3 & 2 & & 2 & 5 & & & & & & & & \\
\hline Sag. ferox f. americana & & & & 1 & 4 & & & & & & & 3 & 70 & 65 & 69 & 58 & 69 & & & & & & & & \\
\hline Sag. robusta & & & & 1 & 7 & 3 & & & & 1 & & 11 & 16 & 2 & & 2 & 1 & & & 4 & 4 & 75 & 13 & & \\
\hline Sag. bedoti & & & & & 1 & & & 5 & & 6 & & 20 & 38 & $\overline{4}$ & 137 & 1 & 12 & 32 & & 1 & 1 & 15 & 7 & 101 & \\
\hline Sag. pulchra & & & & & & & & 1 & & & $\overline{1}$ & 2 & 1 & & 2 & & & 27 & 6 & & $\overline{1}$ & 1 & 1 & & \\
\hline Sag. friderici & 101 & 23 & & & & & & & & & $\overline{1}$ & & & & & & & & 3 & 7 & 1 & 1 & 8 & 36 & 3 \\
\hline Sag. pacifica & 50 & 273 & 29 & 76 & 64 & 38 & 111 & 150 & $\overline{377}$ & 222 & 324 & 401 & 144 & 92 & 157 & 148 & 115 & 211 & 170 & 126 & 296 & 287 & 383 & 45 & 178 \\
\hline Sag. tasmanica & 247 & 17 & 15 & 18 & 27 & 28 & 88 & 264 & 5 & 108 & 131 & 41 & & 2 & 7 & 2 & 4 & 35 & 71 & 71 & 13 & 26 & 140 & 169 & 39 \\
\hline Sag. pseudoserratodentata & 11 & 49 & 3 & & & & & & & & 3 & & & & & & & 1 & & & & & & & \\
\hline Sag. neglecta & & & & & & & & & & & 1 & 6 & 38 & 3 & 18 & 3 & 2 & 3 & & 1 & & & & 5 & \\
\hline Sag. regularis & & & & 1 & & & 18 & $\overline{9}$ & 14 & 32 & 8 & 22 & 5 & 2 & & & 2 & 52 & 45 & 38 & 26 & 149 & 29 & 1 & 1 \\
\hline Sag. minima & 137 & 9 & 2 & 5 & 15 & 2 & 17 & 5 & 8 & 31 & 15 & 7 & 3 & & & 2 & 1 & 39 & 35 & 10 & 10 & 5 & 11 & 23 & 27 \\
\hline Sag. decipiens & 39 & & & & & 2 & 4 & 12 & 10 & $\overline{1}$ & 25 & 7 & & & & & 2 & 4 & 17 & 15 & 3 & 6 & 9 & 1 & 1 \\
\hline Sag. neodecipiens & 20 & & & & & & & & & & 13 & & & & & & & & & & & & 1 & & 9 \\
\hline Sag. planctonis & 2 & & & & & & 2 & & 1 & & & & & & & & & & & & & & & & 2 \\
\hline Pterosag. draco & & 5 & 17 & 28 & 213 & 290 & 27 & 120 & 16 & 203 & 22 & 209 & 172 & 10 & 4 & 13 & 13 & 81 & 182 & 93 & 404 & 326 & 178 & 12 & 18 \\
\hline Ktta. subtilis & $\overline{8}$ & 44 & 22 & 3 & & 23 & 51 & 53 & 68 & 51 & 40 & 51 & 2 & 3 & 1 & & 2 & 42 & 40 & 41 & 10 & 112 & 84 & 48 & 31 \\
\hline Ktta. pacifica & & & 1 & 5 & & & 10 & 5 & & 5 & 4 & 11 & 3 & 15 & 17 & 11 & 1 & 24 & $\overline{1}$ & 1 & 20 & 7 & 4 & & \\
\hline Eukr. hamata & & & & & & 1 & 2 & 4 & 22 & $\overline{6}$ & 2 & & & & & & & & & 7 & 4 & & 3 & 3 & \\
\hline Damaged specimens or juv. & 82 & 20 & 13 & 23 & 16 & 12 & 10 & 44 & 73 & $\overline{23}$ & 21 & 57 & $\overline{46}$ & 29 & 19 & 6 & 40 & 217 & 91 & 123 & 226 & 236 & 251 & 162 & 51 \\
\hline total number & 788 & 472 & 248 & 632 & 1132 & 1049 & 552 & 1036 & 1134 & 1249 & 699 & 1409 & 854 & 359 & 628 & 322 & 363 & 1323 & 1222 & 1400 & 1795 & 2266 & 1959 & 871 & 1161 \\
\hline number of species & 13 & 10 & 10 & 11 & 11 & 12 & 13 & 14 & 12 & 14 & 17 & 17 & 14 & 13 & 11 & 12 & 15 & 15 & 13 & 16 & 16 & 15 & 17 & 14 & 13 \\
\hline
\end{tabular}




\begin{tabular}{|c|c|c|c|c|c|c|c|c|c|c|c|c|c|c|c|c|c|c|c|c|c|c|c|c|c|}
\hline Stations & \begin{tabular}{|l|} 
S B \\
115
\end{tabular} & $\begin{array}{l}\text { S B } \\
118\end{array}$ & $\begin{array}{l}\text { S B } \\
122\end{array}$ & $\begin{array}{l}\mathrm{SB} \\
125\end{array}$ & $\begin{array}{l}\text { SB B } \\
130\end{array}$ & $\begin{array}{l}\text { S B } \\
132\end{array}$ & $\begin{array}{l}\text { S B } \\
137\end{array}$ & $\begin{array}{l}\text { S B } \\
142\end{array}$ & $\begin{array}{l}\text { S B } \\
145\end{array}$ & $\begin{array}{l}\text { S B } \\
150\end{array}$ & $\begin{array}{l}\text { S B } \\
155\end{array}$ & $\begin{array}{l}\text { SB } \\
160\end{array}$ & $\begin{array}{l}\text { SB } \\
166\end{array}$ & $\begin{array}{l}\text { S B } \\
170\end{array}$ & $\begin{array}{l}\text { S B } \\
175\end{array}$ & $\begin{array}{l}\mathrm{SB} \\
180\end{array}$ & $\begin{array}{l}\text { S B } \\
181\end{array}$ & $\begin{array}{l}\mathrm{S} B \\
187\end{array}$ & $\begin{array}{l}\text { S B B } \\
195\end{array}$ & $\begin{array}{l}\text { S B } \\
200\end{array}$ & $\underset{210}{\mathrm{SB}}$ & $\underset{215}{\mathrm{~S} B}$ & $\underset{217}{\mathrm{~S} B}$ & F.o. & $\begin{array}{c}\text { Mean } \\
\text { percentage }\end{array}$ \\
\hline Sag. hexaptera & 60 & 18 & 85 & 29 & 12 & 15 & 3 & 16 & 39 & 40 & 75 & 69 & 55 & 168 & 71 & 59 & 40 & 52 & 46 & 25 & 4 & & 2 & 98 & 6 \\
\hline Sag. lyra & 5 & 7 & 2 & 9 & & & & 1. & 10 & 16 & 28 & 11 & & 2 & 26 & 62 & 5 & 2 & & 1 & & 1 & 4 & 73 & 2 \\
\hline Sag. enflata & 267 & 52 & 398 & 42 & 155 & 31 & 42 & 226 & 567 & 374 & 527 & 350 & 416 & 895 & 333 & 366 & 315 & 811 & 83 & 1118 & 116 & 429 & 433 & 100 & 33 \\
\hline Sag. bipunctata & & & & & & & & & & & & 1 & & & 3 & & & & & 10 & & & & 25 & 1 \\
\hline Sag. ferox f. ame icana & & & & & & & & & & & & 16 & 1 & & 19 & 1 & & 4 & & 13 & 101 & & & 31 & 6 \\
\hline Sag. robusta & & & & & & & & 2 & 3 & 8 & 8 & 4 & & & 8 & 5 & 4 & & 2 & 5 & & & & 48 & 1 \\
\hline Sag. bedoti & & & & & & & & & & & 30 & 11 & 215 & 299 & 27 & 41 & 7 & 131 & 12 & 105 & & 1 & 2 & 56 & 4 \\
\hline Sag. pulchra & & & & & & & & & & & 42 & 11 & 201 & 136 & 16 & 38 & 6 & 51 & & 48 & & & & 39 & 2 \\
\hline Sag. friderici & & 1 & 1 & & & & & & & & & & & & & & & & & & & & & 25 & 2 \\
\hline Sag. pacifica & 635 & 117 & 34 & 80 & 156 & 70 & 92 & 116 & 382 & 308 & 400 & 403 & 106 & 186 & 235 & 324 & 234 & 318 & 31 & 238 & 156 & 78 & 171 & 100 & 22 \\
\hline Sag. tasmanica & 97 & 25 & 43 & 17 & 18 & 26 & 202 & 55 & 86 & 85 & 87 & 53 & 1 & 8 & 121 & 173 & 83 & 278 & 55 & 8 & 72 & 113 & 86 & 98 & 8 \\
\hline Sag. pseudoserratodentata & & & & & & & & & & & & & & & & & & & & 2 & & 5 & 3 & 17 & 2 \\
\hline Sag. neglecta & & & & & & & & & & & 1 & 19 & 5 & 29 & 4 & & 1 & 7 & 2 & 8 & 1 & & & 42 & 1 \\
\hline Sag. regularis & 3 & 1 & & & & & & & 2 & 30 & 4 & 15 & & & 10 & 7 & 59 & 3 & 8 & 17 & 2 & & 1 & 67 & 2 \\
\hline Sag. minima & 7 & 1 & 6 & 3 & 4 & 3 & 11 & 8 & 4 & 1 & 32 & 1 & 5 & 12 & 19 & 14 & 36 & 3 & 10 & 1 & 6 & 53 & 183 & 96 & 2 \\
\hline Sag. decipiens & & & 15 & & 3 & & & & 5 & 2 & 20 & 10 & & & 10 & 14 & 5 & 6 & 6 & 10 & 1 & & 15 & 65 & 1 \\
\hline Sag. neodecipiens & & & 3 & & 1 & & & & 1 & 1 & & & & & & & 1 & & & & & 1 & 3 & 23 & 1 \\
\hline Sag. planctonis & & & & & & & & & & & & & & 1 & & & & & & & & & & 10 & $*$ \\
\hline Pterosag. draco & 77 & 9 & 1 & 6 & 11 & 1 & 43 & 218 & 219 & 59 & 208 & 308 & 21 & 34 & 283 & 140 & 94 & 98 & 71 & 483 & 16 & 1 & & 96 & 9 \\
\hline Ktta. subtilis & 2 & 2 & 10 & 2 & 30 & & 10 & 15 & 9 & 7 & 67 & 89 & 13 & 64 & 89 & 147 & 8 & 82 & 15 & 20 & & 5 & 9 & 92 & 3 \\
\hline Ktta. pacifica & 1 & 1 & & & 2 & 5 & 60 & 186 & 85 & 9 & 63 & 30 & 76 & 26 & 71 & 10 & 13 & 26 & 2 & 12 & 63 & 7 & 4 & 81 & 2 \\
\hline Eukr. hamata & & 1 & & & & & & & & & 16 & & & & & & & & & & & & & 25 & * \\
\hline Damaged specimens or juv. & 48 & 48 & 11 & 12 & 31 & 18 & 19 & 22 & 86 & 19 & 100 & 38 & 18 & 79 & 38 & 610 & 11 & 55 & 73 & 24 & 24 & 46 & 23 & 100 & 6 \\
\hline total number & 1202 & 283 & 609 & 200 & 423 & 169 & 482 & 865 & 1498 & 959 & 1708 & 1439 & 1133 & 1939 & 1383 & 2011 & 922 & 1927 & 416 & 2148 & 562 & 740 & 939 & \multirow{2}{*}{\multicolumn{2}{|c|}{$*$ less than 0.5}} \\
\hline number of species & 10 & 12 & 11 & 8 & 10 & 7 & 8 & 10 & 13 & 13 & 16 & 17 & 12 & 13 & 17 & 15 & 16 & 15 & 13 & 18 & 11 & 11 & 13 & & \\
\hline
\end{tabular}




\begin{tabular}{|c|c|c|c|c|c|c|c|}
\hline Stations & $\begin{array}{l}\mathrm{EQP} \\
\mathrm{S} 28\end{array}$ & $\begin{array}{l}\mathrm{EQP} \\
\mathrm{H} 3\end{array}$ & $\begin{array}{l}\text { EQP } \\
\text { H } 7\end{array}$ & $\begin{array}{l}\mathrm{EQP} \\
\mathrm{H} 11\end{array}$ & $\begin{array}{l}\text { EQP } \\
\mathrm{H} 17\end{array}$ & F. $\mathrm{O}$. & $\begin{array}{c}\text { Mean } \\
\text { percentage }\end{array}$ \\
\hline Sag. hexaptera & 109 & 29 & 41 & 62 & 57 & 100 & 13 \\
\hline Sag. enflata & 688 & 56 & 180 & 431 & 348 & 100 & 40 \\
\hline Sag. bipunctata & 12 & 6 & 1 & 1 & 32 & 100 & 2 \\
\hline Sag. ferox & 1 & 2 & & & 6 & 60 & 1 \\
\hline Sag. robusta & 5 & 3 & 5 & 9 & 9 & 100 & 1 \\
\hline Sag. pulchra & & & & 17 & 2 & 40 & 1 \\
\hline Sag. pacifica & 203 & 60 & 66 & 231 & 35 & 100 & 17 \\
\hline Sag. pseudoserratodentata & & & 3 & & & 20 & 1 \\
\hline Sag. neglecta & 5 & & & & & 20 & $*$ \\
\hline Sag. oceania & 7 & & & & & 20 & 1 \\
\hline Sag. regularis & 29 & 1 & 7 & 20 & 32 & 100 & 2 \\
\hline Sag. minima & & & & 2 & & 20 & $*$ \\
\hline Sag. decipiens & 14 & 1 & 8 & 17 & 26 & 100 & 2 \\
\hline Pterosag. draco & 73 & 21 & 81 & 204 & 315 & 100 & 17 \\
\hline Ktta. subtilis & & 1 & 5 & 1 & 2 & 80 & 1 \\
\hline Ktta. pacifica & & & & 12 & 15 & 40 & 2 \\
\hline Damaged specimens or juv. & 99 & 9 & 113 & 63 & 29 & 100 & 9 \\
\hline total number & 1245 & 189 & 510 & 1070 & 908 & \multirow{2}{*}{\multicolumn{2}{|c|}{ * less than 0.5}} \\
\hline number of species & 11 & 10 & 10 & 12 & 12 & & \\
\hline
\end{tabular}

Appendix Table 7. Occurrence of chaetognaths in samples of the Equapac Expedition. 


\begin{tabular}{|c|c|c|c|c|c|c|c|c|c|c|c|c|c|c|c|c|c|c|c|c|c|c|c|c|c|c|c|}
\hline \multirow{2}{*}{8} & \multicolumn{5}{|c|}{$\begin{array}{l}\text { North Equatorial } \\
\text { Current }\end{array}$} & \multicolumn{9}{|c|}{ Counter Equatorial Current } & \multicolumn{11}{|c|}{ South Equatorial Current } & \multirow[b]{2}{*}{ F.O. } & \multirow[b]{2}{*}{$\begin{array}{c}\text { Mean } \\
\text { percentage }\end{array}$} \\
\hline & 2 & 3 & 4 & 52 & 53 & 5 & 6 & \begin{tabular}{l|l}
7 & 8 \\
\end{tabular} & \begin{tabular}{l|l|}
8 & 54 \\
\end{tabular} & 55 & \begin{tabular}{l|l}
56 & 5 \\
\end{tabular} & \begin{tabular}{l|l}
57 & 58 \\
\end{tabular} & \begin{tabular}{l|l}
58 & 59 \\
\end{tabular} & \begin{tabular}{l|l}
59 & 60 \\
\end{tabular} & 9 & \begin{tabular}{|l|l}
10 & 1 \\
\end{tabular} & \begin{tabular}{l|l}
11 & 12 \\
\end{tabular} & \begin{tabular}{|l|l|}
2 & 13 \\
\end{tabular} & \begin{tabular}{l|l}
15 \\
\end{tabular} & \begin{tabular}{l|l}
61 & 62 \\
\end{tabular} & \begin{tabular}{|l|l|}
2 & 63 \\
\end{tabular} & 64 & \begin{tabular}{l|l}
65 & 6 \\
\end{tabular} & \begin{tabular}{l|l}
66 & 6 \\
\end{tabular} & \begin{tabular}{l|l}
67 & $F$ \\
\end{tabular} & & \\
\hline Sag. hexaptera & & & & & & & . & & 3 & & & & & 1 & & & & & 1 & & 2 & 2 & & & & 14 & 5 \\
\hline Sag. enflata & 3 & & 7 & 3 & 28 & 14 & 6 & $\begin{array}{lll}47 & 28 \\
\end{array}$ & 28 & 12 & 21 & 12 & $\begin{array}{lll}7 & 1 \\
\end{array}$ & 13 & 37 & 82 & $25 \quad 20$ & 0 & 16 & 1730 & $3 0 \longdiv { 4 9 }$ & 47 & $5 0 \longdiv { 6 }$ & $\begin{array}{lll}61 & 12\end{array}$ & 12 & 97 & 35 \\
\hline Sag. ferox & & & & 3 & 6 & & & & 2 & & & 2 & & & & & & 1 & & & 3 & 3 & & & \begin{tabular}{l|l}
2 & 2
\end{tabular} & 24 & 11 \\
\hline Sag. bedoti & & & & & & 9 & 8 & 285 & \begin{tabular}{|l|l|}
5 & 1 \\
\end{tabular} & 3 & 7 & 3 & & 1 & 22 & 5 & $\begin{array}{ll}7 & 3\end{array}$ & 3 & 2 & $\overline{1} 1 \overline{12}$ & 2 & 10 & 171 & 18 & 24 & 69 & 13 \\
\hline Sag. pulchra & & & & & & & & & & & 5 & & & & & & & & & & & & & 4 & & 7 & 7 \\
\hline Sag. pacifica & 1 & 1 & & & 2 & 6 & 1 & 432 & 2 & & 5 & 91 & 1212 & 125 & 25 & 12 & 56 & $\begin{array}{ll}6 & 11 \\
\end{array}$ & 21 & $10 \quad 10$ & 0 & 5 & 72 & 20 & 8 & 86 & 20 \\
\hline Sag. neglecta & & & & & 2 & 3 & & & $1 \quad 1$ & & & & & & 2 & & 4 & 13 & 14 & 1 & 30 & 10 & 6 & $8 \quad 1:$ & $15:$ & 52 & 8 \\
\hline Sag. regularis & 3 & 3 & 10 & & 18 & 15 & 7 & \begin{tabular}{l|l}
12 & 7
\end{tabular} & \begin{tabular}{l|l|}
7 & 7 \\
\end{tabular} & 20 & 1 & 6 & & 1 & 15 & 5 & $1 \longdiv { 5 }$ & 511 & & 1016 & $\begin{array}{ll}6 & 17\end{array}$ & 11 & 262 & $20:$ & \begin{tabular}{l|l}
3 & 8
\end{tabular} & 86 & 21 \\
\hline Sag. bedfordii & & & & & & & & & & & & & & & & $\overline{1}$ & & & & & 3 & & & 1 & & 10 & 2 \\
\hline Pterosag. draco & & & & & & 5 & 1 & $\begin{array}{ll}5 & 7\end{array}$ & \begin{tabular}{ll|}
7 & 1 \\
\end{tabular} & 4 & 11 & 2 & 13 & $\begin{array}{ll}3 & 6 \\
\end{array}$ & 8 & 5 & $\begin{array}{ll}9 & 8 \\
\end{array}$ & 84 & & 109 & 9 & 8 & 141 & 11 & 6 & 79 & 11 \\
\hline Ktta. subtilis & & & & & & & & 1 & & & & & & & & & & & & & & & & & & 3 & 1 \\
\hline Ktta. pacifica & & & & & & 7 & 2 & 6 & 6 & & & 1 & & & 1. & 1 & 2 & $\begin{array}{ll}2 & 1 \\
\end{array}$ & 8 & 1 & & 2 & 1 & 6 & 6 & 48 & 5 \\
\hline Damaged specimens or juv. & & & & & 18 & & 1 & & & & & & & & & & & & 29 & 13 & 3 & 2 & & 1 & & 24 & 11 \\
\hline total number & 7 & 4 & 17 & 6 & 74 & 59 & \begin{tabular}{l|l}
26 & 9 \\
\end{tabular} & \begin{tabular}{l|l}
97 & 86 \\
\end{tabular} & \begin{tabular}{l|l|}
6 & 35 \\
\end{tabular} & 39 & \begin{tabular}{l|l}
50 & 3 \\
\end{tabular} & \begin{tabular}{l|l}
35 & 2 \\
\end{tabular} & \begin{tabular}{l|l}
20 & 18 \\
\end{tabular} & \begin{tabular}{|l|l|}
8 & 15 \\
\end{tabular} & 110 & \begin{tabular}{l|l}
37 & 5 \\
\end{tabular} & \begin{tabular}{l|l}
51 & 45 \\
\end{tabular} & \begin{tabular}{|l|l|}
5 & 48 \\
\end{tabular} & \begin{tabular}{|l|l|}
91 & 5 \\
\end{tabular} & \begin{tabular}{l|l}
50 & 93 \\
\end{tabular} & $\begin{array}{ll}3111 \\
\end{array}$ & 95 & \begin{tabular}{|l|l|}
121 & 14 \\
\end{tabular} & \begin{tabular}{l|l}
140 & 7 \\
\end{tabular} & 76 & & \\
\hline number of species & 3 & 2 & 2 & 2 & 5 & 7 & 6 & \begin{tabular}{l|l}
6 & 7
\end{tabular} & \begin{tabular}{l|l|}
7 & 7
\end{tabular} & 4 & 6 & 7 & \begin{tabular}{l|l}
3 & 5 \\
3
\end{tabular} & \begin{tabular}{l|l}
5 & 4
\end{tabular} & 7 & 7 & \begin{tabular}{l|l}
6 & 7
\end{tabular} & \begin{tabular}{l|l|l|}
7 & 7
\end{tabular} & 6 & \begin{tabular}{l|l}
7 & 6 \\
\end{tabular} & 6 & 7 & 7 & 9 & 8 & & \\
\hline
\end{tabular}

